InmaCulada Postigo Gómez, Ana Jorge Alonso

Coordinadoras

\title{
E1 tratamiento informativo de la violencia contra las mujeres
}

Cuadernos Artesanos de Comunicación / 86
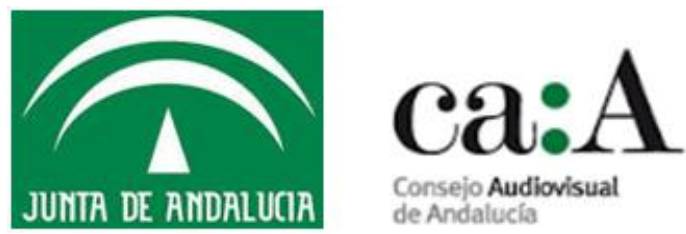

Consejo Audiovisual

de Andalucía

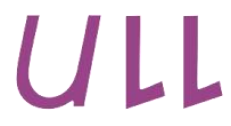

Universidad de La Laguna
Universitat d'Alacant Universidad de Alicante
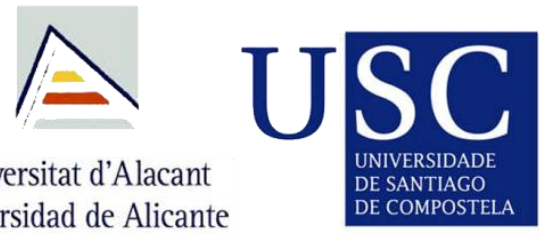

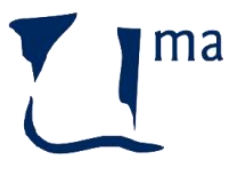

UNIVERSIDAD DE M A LAGA

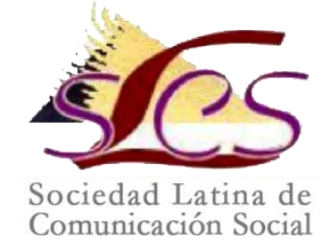


Cuadernos Artesanos de Comunicación \# 86- Comité Científico

Presidencia: José Luis Piñuel Raigada (UCM)

Secretaría: Concha Mateos (URJC)

- Bernardo Díaz Nosty (Universidad de Málaga, UMA)

- Carlos Elías (Universidad Carlos III de Madrid, UC3M)

- Javier Marzal (Universidad Jaume I, UJI)

- José Luis González Esteban (Universitas Miguel Hernández de

Elche, UMH)

- José Luis Terrón (Universidad Autónoma de Barcelona, UAB)

- José Miguel Túñez (Universidad de Santiago, USC)

- Juan José Igartua (Universidad de Salamanca, USAL)

- Marisa Humanes (Universidad Rey Juan Carlos, URJC)

- Miguel Vicente (Universidad de Valladolid, UVA)

- Miquel Rodrigo Alsina (Universidad Pompeu Fabra, UPF)

- Núria Almiron (Universidad Pompeu Fabra, UPF)

- Ramón Reig (Universidad de Sevilla, US)

- Ramón Zallo (Universidad del País Vasco, UPV-EHU)

- Victoria Tur (Universidad de Alicante, UA)

\section{(c) $(\mathbb{D} \otimes \Theta$}

* Este libro y cada uno de los capítulos que contiene, así como las imágenes incluidas, si no se indica lo contrario, se encuentran bajo una Licencia Creative Commons Atribución -No Comercial- Sin Derivadas 3.0 Unported. Puede ver una copia de esta licencia en http://creativecommons.org/licenses/by-ncnd/3.0/ Esto significa que Ud. es libre de reproducir y distribuir esta obra, siempre que cite la autoría, que no se use con fines comerciales o lucrativos y que no haga ninguna obra derivada. Si quiere hacer alguna de las cosas que aparecen como no permitidas, contacte con los coordinadores del libro o con el autor del capítulo correspondiente.

Queda expresamente autorizada la reproducción total o parcial de los textos publicados en este libro, en cualquier formato o soporte imaginables, salvo por explícita voluntad en contra del autor o autora o en caso de ediciones con ánimo de lucro. Las publicaciones donde se incluyan textos de esta publicación serán ediciones no comerciales y han de estar igualmente acogidas a Creative Commons. Harán constar esta licencia y el carácter no venal de la publicación.

* La responsabilidad de cada texto es de su autor o autora. 
Inmaculada Postigo Gómez, Ana Jorge Alonso

(Coordinadoras)

\section{E1 tratamiento informativo de la violencia contra las mujeres}

Cuadernos Artesanos de Comunicación / 86
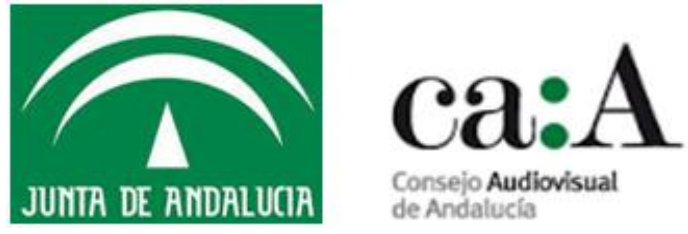

Consejo Audiovisual de Andalucía

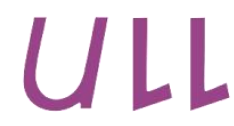

Universidad de La Laguna
Universitat d'Alacant Universidad de Alicante

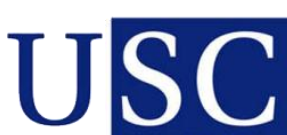

UNIVERSIDADE DE SANTIAGO DE COMPOSTELA

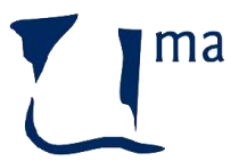

UNIVERSIDAD DEMALAGA

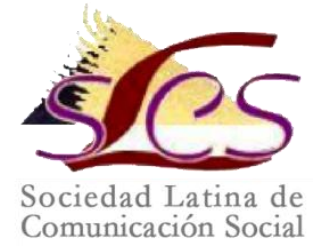


CAC $86^{\circ}$ - El tratamiento informativo de la violencia contra las mujeres

Inmaculada Postigo Gómez, Ana Jorge Alonso (Coords.)

Prólogo: Emelina Fernández Soriano.

Precio social: $10,25 €$ | Precio en librería. 13,35€ |

Editores: Javier Herrero y Alberto Ardèvol Abreu

Diseño: F. Drago

Ilustración de portada: Ilustración de portada: Fragmento del cuadro Árboles y viento, de Juan Davó (sin fecha).

Imprime y distribuye: F. Drago. Andocopias S. L.

c/ La Hornera, 41. La Laguna. Tenerife.

Teléfono: 922250554 | fotocopiasdrago@,telefonica.net

Edita: Sociedad Latina de Comunicación Social - edición no venal

- La Laguna (Tenerife), 2015 - Creative Commons

(http://www.revistalatinacs.org/09/Sociedad/estatutos.html)

Catálogo http://www. cuadernosartesanos.html

Protocolo de envío de manuscritos con destino a C.A.C.:

http://www.cuadernosartesanos/protocolo.html

Descargar $p d f$ :

http://www.cuadernosartesanos.org/\#86

ISBN - 13: 978-84-16458-18-9

DL: TF-505-2015

DOI: $\underline{10.4185 / \operatorname{cac} 86}$ 


\section{E1 tratamiento informativo de la violencia contra las mujeres}

\section{Resumen}

La violencia contra las mujeres ha formado parte de la vida cotidiana a lo largo de los siglos como consecuencia del sistema patriarcal. A pesar de ello, a pesar de que alrededor de 60 mujeres son asesinadas cada año en nuestro país y de que se está produciendo un retroceso realmente importante sobre todo en la población joven, para la ciudadanía existen otros problemas más urgentes, como son el paro, la corrupción, o el fraude.

Los medios de comunicación audiovisual son, por su carácter decisivo en la construcción del imaginario colectivo, un elemento esencial para el estudio de los modelos de género vigentes, así como un instrumento idóneo para la desarticulación de estereotipos.

En este contexto, el presente volumen es fruto del trabajo desarrollado durante años por diversos autores que, desde la investigación universitaria, trabajan en la difícil tarea de desenmascarar la violencia machista, instalada profundamente en la sociedad.

Tres líneas son las que articulan esta obra. La primera de ellas, (capítulos 1, 2 y 3) son el resultado del proyecto de excelencia de la Junta de Andalucía Observatorio del Tratamiento Informativo de la Violencia de Género con especial atención a la identidad étnica/cultural, y que dan luz acerca de los mecanismos de producción y difusión mediática de las noticias informativas sobre violencia machista, así como de aquellos aspectos que distorsionan o, en cambio, suponen buenas prácticas en la transmisión y recepción de estos mensajes. El segundo bloque se constituye por los capítulos del 4 al 10, en el que se recogen aportaciones desde perspectivas diferentes y que amplían y complementan los resultados obtenidos por el Observatorio. Se abarcan cuestiones como el papel principal que deben asumir los Consejos Audiovisuales (capítulo 4), la importancia de la inclusión de indicadores de género en las investigaciones sobre medios de comunicación (capítulo 5), la vertiente psico-educativa a la hora de construir estos mensajes (capítulos 6, 7, 10), así como las nuevas formas de creación en los formatos digitales y en red (capítulos 8 y 9). Por último y a modo de cierre, el capítulo 11 es una reflexión que nos regala Margarita Ledo de su experiencia vital como feminista y 
cineasta comprometida: "empiezo este relato, casi íntimo, como creadora y como ensayista, como alguien que escribe y hace cine porque también es docente e investigadora”.

Palabras clave: Violencia machista, violencia contra las mujeres, género, igualdad, feminismo, comunicación, redes sociales

Forma de citar este libro

Autor del capítulo, en Inmaculada Postigo Gómez, Ana Jorge Alonso (Coordinadores) (2015): El tratamiento informativo de la

violencia contra las mujeres. Cuadernos Artesanos de Comunicación, 86. La Laguna (Tenerife): Latina. 


\section{ÍNDICE}

\section{PRÓLOGO}

Emelina Fernández Soriano ............................... 9

\section{CAPÍTULO 1}

OBSERVATORIO ANDALUZ DE LA VIOLENCIA MACHISTA EN LOS MEDIOS AUDIOVISUALES (OB-VIO). HACIA UNA OPORTUNIDAD DE SENSIBILIZACIÓN Inmaculada Postigo Gómez $\ldots \ldots \ldots \ldots \ldots \ldots \ldots \ldots \ldots \ldots \ldots \ldots \ldots \ldots$

\section{CAPÍTULO 2}

LA ACTUALIZACIÓN DE LOS CÓDIGOS DE BUENAS PRÁCTICAS EN LOS MEDIOS AUDIOVISUALES. UNA NECESIDAD PARA LA LUCHA CONTRA LA VIOLENCIA MACHISTA

Antonio A. Caballero Gálvez .............................. 41

\section{CAPÍTULO 3}

DESPUÉS DE LAS NOTICIAS: EXPERIENCIAS CON LOS GRUPOS DE DISCUSIÓN EN EL OBSERVATORIO ANDALUZ DE VIOLENCIA MACHISTA EN LOS MEDIOS AUDIOVISUALES

Concha Barquero Artés

\section{CAPÍTULO 4}

EL PAPEL GARANTISTA DEL CONSEJO AUDIOVISUAL DE ANDALUCÍA DEL TRATAMIENTO INFORMTATIVO ÉTICO DE LA VIOLENCIA MACHISTA EN LOS MEDIOS Ana Jorge Alonso .................................... 75

\section{CAPÍTULO 5}

MEDICIONES E ÍNDICES DE EVALUACIÓN INCLUSIVOS: EXAMEN DE LOS INDICADORES DE GÉNERO Y MEDIOS DE COMUNICACIÓN Ruth Ainhoa de Frutos García ............................ 101 
VIOLENCIA DE GÉNERO Y MEDIOS DE COMUNICACIÓN

José María Calleja ............................................131

CAPÍTULO 7

LA VIOLENCIA MACHISTA: CONCEPTOS E IMPLICACIONES PSICOSOCIALES

Trinidad Núñez Domínguez

CAPÍTULO 8

DE VIOLENCIAS, PROCESOS DE RESIGNIFICACIÓN Y CIBERFEMINISMO

María José Gámez Fuentes. Laura Castillo Mateu ............... 179

CAPÍTULO 9

LO ICONOGRÁFICO HACE HERIDA. ESTEREOTIPOS EN PLATAFORMAS DE MINIJUEGOS PARA CHICAS

Rocío de la Maya Retamar ...................................... 195

CAPÍTULO 10

VER LA VIOLENCIA, COMUNICAR LA EQUIDAD.

DIAGNÓSTICO Y PRÁCTICA DOCENTE

$\mathrm{M}^{a}$ Teresa Vera Balanza ..................................... 211

CAPÍTULO 11

EL CUERPO, ESA INSOPORTABLE LENGUA COMUNAL Margarita Ledo Andión ...................................... 235

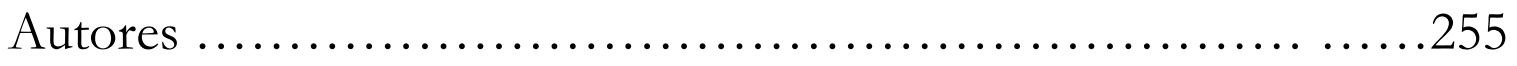




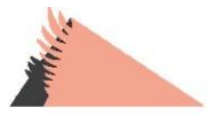 \\ Prólogo
}

\author{
Emelina Fernández Soriano \\ Presidenta del Consejo Audiovisual de Andalucía
}

$\mathrm{M}$ ÁS de 700 mujeres han sido víctimas mortales de la violencia machista en nuestro país durante el último decenio. 54 fueron asesinadas durante 2013 y 53 durante el pasado 2014. Son cifras inasumibles que apenas muestran avances significativos, además, todos sabemos que estas muertes son la punta del iceberg de un gran drama sumergido, el de miles de mujeres maltratadas a diario física y psicológicamente por sus parejas y exparejas. Lo que hacemos no es suficiente, esas mujeres necesitan la ayuda de nuestra sociedad y nuestros medios de comunicación tienen mucho que decir al respecto. Tienen que contar esa tragedia y tienen que hacerlo con rigor para que tomemos conciencia de que el problema es verdaderamente muy grave, viene de lejos y debemos atajarlo desde la raíz.

¿Cómo puede llamarse a sí misma democrática una sociedad que tolera que se vulneren los derechos de más de la mitad de su población?, ¿cómo nos podemos reconocer en el espejo como una sociedad desarrollada mientras las mujeres son agredidas y asesinadas en un caldo de cultivo alimentado por la tradición patriarcal?, ¿cómo podemos llamar a nuestro territorio primer mundo cuando se trata de un mundo brutal, insolidario e injusto que maltrata a sus mujeres y las convierte en ciudadanas de segunda?, ¿cómo podemos permanecer impasibles sin cortar de una vez por todas la hemorragia por la que se 
escapa el sueño de una comunidad en la que todos y todas tengamos las mismas oportunidades reales, los mismos derechos efectivos? Sin respeto, no hay democracia, no hay convivencia, no hay futuro.

Y no se trata de buscar torniquetes o parches para salir del paso, se trata de desterrar del ideario colectivo para siempre los valores que puedan inducir a pensar que la mujer es inferior, casi un objeto, una persona sin verdadera autoridad, sin auténtica dignidad. Y aquí, en este tremendo reto que tenemos por delante es donde están llamados a jugar un papel protagonista los medios. Concebidos para entretenernos y proporcionarnos una información veraz y plural, son también un potente transmisor de valores cívicos y hábitos de vida. Son sin duda un instrumento fundamental para ilustrar a la sociedad, para formarnos y hacer que tomemos conciencia de nuestros grandes problemas colectivos. Los medios nos están ayudando a realizar el diagnóstico, pero también deben ser parte del tratamiento, ya que sólo en el ejercicio responsable e integral de su función de servicio público pueden estar a la altura de una tragedia como la violencia machista, sólo dando lo mejor de ellos pueden contribuir a acabar con lo peor de nosotros.

Y no es una cuestión que solo incumba a los medios, claro está, los organismos públicos deben ser ejemplares en esta lucha sin cuartel. Ese precisamente fue el propósito del Consejo Audiovisual de Andalucía (CAA) y la Consejería de Innovación, Ciencia y Empresa de la Junta cuando en diciembre de 2009 firmaron un convenio de colaboración para establecer una línea prioritaria de investigación sobre comunicación audiovisual. Ese acuerdo fue el marco en el que se concibió y lanzó una convocatoria dirigida a investigadores de las universidades andaluzas sobre temas - entre muchos otros- como la igualdad y la cohesión social, los dos aspectos en los que se centra el Observatorio Andaluz de Violencia Machista en los Medios Audiovisuales (ObVio).

La investigación ha sido llevada a cabo por profesores y profesoras de la Universidad de Málaga y persigue conocer los mecanismos de producción y difusión mediática de las noticias sobre violencia machista. Para ello, se puso el foco sobre informaciones que tratan 
esa violencia en todas sus vertientes (agresiones y asesinatos, campañas de prevención, actividades de concienciación) y formatos (noticias, entrevistas, debates). El objetivo era conocer mejor los aspectos que son contraproducentes en la transmisión de los mensajes audiovisuales sobre violencia machista, y también poner en valor los que se difunden siguiendo las buenas prácticas comunicativas. El análisis crítico del archivo generado durante la investigación, las entrevistas realizadas entre los profesionales de los medios o los cuestionarios que se han cursado entre psicólogos, juristas, asociaciones de apoyo a la víctimas... configuran un valioso material al que ahora hay que sumar esta publicación, que sirve de colofón al proyecto y compendia la información generada, las principales conclusiones que se han derivado de la misma y otras aportaciones expresamente encargadas a especialistas que no habían tomado parte hasta ahora en esta iniciativa.

Si bien hay un capítulo dedicado específicamente al rol que desempeña el Consejo Audiovisual de Andalucía en la tarea de garantizar que el tratamiento informativo de los casos de violencia machista discurra según los códigos deontológicos y la propia ley vigente, estas páginas abordan otros muchos asuntos de interés, como la necesidad de sensibilizar a la sociedad, la urgente actualización de los códigos éticos, la revisión de los indicadores que miden y evalúan los contenidos discriminatorios, las implicaciones psicosociales de esta violencia, la aparición del ciberfeminismo, el papel de los docentes, los estereotipos en las plataformas de minijuegos... y un largo etcétera que convierte esta publicación en una propuesta en la que concurren múltiples enfoques de una misma problemática.

El Consejo Audiovisual de Andalucía valora positivamente el esfuerzo realizado durante los últimos años por los operadores de televisión públicos para visibilizar y denunciar la violencia de género, si bien, hay que insistir en la necesidad de que sigan aumentando las voces masculinas en estas informaciones, pues de lo contrario se traslada la idea de que la violencia de género es un problema exclusivo de las mujeres. Tampoco podemos olvidarnos de fomentar la difusión de casos de mujeres que han superado con éxito 
situaciones críticas de violencia de género, mandando un mensaje de esperanza y optimismo a un colectivo vulnerable y castigado, al tiempo que se redobla la información sobre los recursos -como el teléfono 016- que la Administración pone a su servicio para intentar salir de esa dramática situación.

Otra de las cuestiones a las que debemos prestar atención es la conveniencia de que los medios de comunicación acudan con más frecuencia a personas expertas para contextualizar este tipo de informaciones. En este sentido, los códigos de autorregulación recomiendan no abusar de los testimonios del entorno de la víctima, que no aportan información concreta, sino opiniones circunstanciales sobre las relaciones de la pareja y de las personas implicadas. Asimismo, las noticias sobre violencia machista no pueden recurrir a una presentación desnuda de los crímenes, desprovista de la función social y pedagógica que se espera de los medios. Este tipo de violencia debe presentarse como un fenómeno progresivo, no como hechos puntuales y aislados. Es un drama que hunde sus raíces en modelos de conducta sexistas y discriminatorios transmitidos desde hace siglos.

Los datos que ha recogido este Observatorio ratifican que hay que seguir trabajando para difundir el valor de la igualdad, hay que continuar vigilantes para no ceder el terreno ganado y dar nuevos pasos hacia delante, como revisar cuanto antes el Código de Autorregulación de Contenidos para adecuarlo a la entrada en vigor de la Ley de Igualdad, la Ley contra la Violencia de Género y la Ley General de la Comunicación Audiovisual. Además, debemos ir más allá de los informativos y pasar también por el tamiz de la justicia y la igualdad los anuncios (continúa la cosificación de la mujer en la publicidad), magacines, teleseries, películas... Debemos hacerlo entre todos, y las instituciones públicas tenemos que ser una referencia para el resto de actores implicados a través de acuerdos de colaboración que deriven en un eficaz entendimiento institucional, como felizmente ha ocurrido en este proyecto. 


\title{
Observatorio Andaluz de Violencia Machista en los Medios Audiovisuales (Ob Vio). Hacia una oportunidad de sensibilización
}

\author{
Inmaculada Postigo Gómez \\ Universidad de Málaga \\ Perfil de Google'. Número Orcid ${ }^{2}$
}

\section{Introducción}

T OS malos tratos a las mujeres se integran en la sociedad de Lorma normalizada y naturalizada, invisible, fruto del sistema androcéntrico que, a lo largo de la historia, ha sostenido y defendido fehacientemente que "los hombres son superiores a las mujeres, que han sido dotados con cualidades diferentes y que han de ejercer roles distintos: el de dominación y el de subordinación, respectivamente" (Bourdieu: 2000: 291-304). Del mismo modo, los medios audiovisuales son mecanismos básicos en la construcción del imaginario colectivo, así como en los modelos de comportamiento que configuran la percepción de la realidad social del individuo y marcan sus pautas de relación con los otros. Son por tanto, una herramienta básica dentro del engranaje político, social, educativo y legislativo que, en función de los mensajes que construyan,

\footnotetext{
${ }^{1}$ https://scholar.google.com/citations?user=25_O-rYAAAAJ\&hl=es

${ }^{2}$ http://orcid.org/0000-0001-8105-9677
} 
favorecerán la lucha contra la violencia machista, o por el contrario, seguirán perpetuándola.

Este artículo es el resultado de la labor desarrollada dentro del proyecto investigador de excelencia de la Junta de Andalucía, (ref.: P11-TIC-7999) denominado Observatorio del Tratamiento Informativo de la Violencia de Género con Atención a la Identidad Cultural/Étnica ${ }^{3}$ (en adelante $\mathrm{Ob} \sim \mathrm{Vio}$ )

\section{La violencia machista y su percepción en la sociedad}

Los medios de comunicación juegan un papel fundamental en la visibilización de la violencia de género. Según Concha Fagoaga (1994 y 1999), con la llegada de las mujeres a cargos de responsabilidad en el mundo del periodismo es cuando este problema comienza a formar parte importante de la agenda informativa de los medios.

El Barómetro del CIS del pasado abril ${ }^{4}$ indicaba, pese a que ya son 15 las víctimas mortales en lo que va de año ${ }^{5}$ de año, que para los españoles los principales problemas que existen actualmente en nuestro país son el paro, la corrupción y el fraude, los problemas de índole económica, y los partidos políticos, obteniendo la violencia contra las mujeres un porcentaje de tan solo el $0,4 \%$, como si de un residuo estructural se tratara.

En las últimas décadas, las instituciones nacionales e internacionales han atendido las demandas ciudadanas y han materializado su posición en distintos foros: la Convención para la Eliminación de

\footnotetext{
${ }^{3}$ Puede consultarse el proyecto en detalle en www.obvio.uma.es

${ }^{4}$ Barómetro de Abril de 2015, número 3080. Disponible en http://www.cis.es/cis/export/sites/default/Archivos/Marginales/3080_3099/3080/es3080mar.pdf

${ }^{5}$ Datos obtenidos del portal estadístico del Ministerio de Sanidad, Servicios Sociales e Igualdad el 22 de junio de 2015 http://www.msssi.gob.es/ssi/violenciaGenero/datosEstadisticos/docs/VMort ales_2015_22_06.pdf
} 
Todas las Formas de Discriminación de la Mujer (ONU, 1979), la Convención Interamericana para Prevenir, Sancionar y Erradicar la Violencia contra la Mujer (OEA, 1994) las conferencias mundiales sobre la mujer, especialmente la Mundial de Beijing de 1995, donde se expresaron como objetivos prioritarios el aumentar el acceso de la mujer y su participación en la expresión de sus ideas y la adopción de decisiones en los medios de difusión y por conducto de ellos, prestando especial interés a las nuevas tecnologías de comunicación por su posibilidad para fomentar una imagen equilibrada y no estereotipada de la mujer en los medios de difusión.

En España, desde los ochenta, la sociedad civil ya estaba movilizándose a través de grupos de mujeres como las Comisiones Anti-Agresiones ${ }^{6}$, transformados luego en un espacio de atención a las víctimas de la violencia, donde cobraron especial protagonismo la Asociación de Mujeres Separadas y Divorciadas y otros grupos como la asociación de juristas Themis ${ }^{7}$, hasta que se materializa la Comisión para la Investigación de los Malos Tratos como iniciativa institucional.

Con todo, el interés público y mediático por la violencia de género, y posteriormente la acción política, se incrementó desde la segunda mitad de los años noventa a raíz del asesinato de Ana Orantes por su ex-marido en diciembre de 1997, pocos días después de su aparición en un programa de televisión explicando las agresiones que sufría. El efecto fue inmediato: la presencia mediática y la conmoción social fueron una. De manera sorpresiva la visibilización del problema era un hecho, el asunto ya era público. Ese mismo año, la Comisión Europea incluyó la violencia en el programa político de la Comunidad

${ }^{6}$ En su mayoría aglutinados en torno a la Coordinadora de Organizaciones Feministas del Estado Español

${ }^{7}$ Asociación de mujeres juristas, fundada el 3 de diciembre de 1987. Tiene como objetivo principal promover la igualdad jurídica entre mujeres y hombres, llevando a cabo todo tipo de acciones que garanticen la efectividad de los derechos de la mujer y haciendo propuestas de cambios en las normas que atenten contra los derechos de las mujeres 
Europea, y puso en marcha una campaña de concienciación a favor de una actitud de "tolerancia cero", fomentando también medidas preventivas. Además, el Consejo de Ministros aprobó, en su reunión del 7 de marzo, el III Plan para la Igualdad de Oportunidades entre Hombres y Mujeres. Desde entonces, las noticias sobre violencia contra las mujeres pasaron de la sección de sucesos a ser denominadas "noticias sobre malos tratos y violencia doméstica". Este cambio es importante porque constata que buena parte de estos episodios violentos reproducen una pauta de desigualdad de género, y que este tipo de violencia debe ser considerado como un tema público $^{10}$.

A raíz de todos estos acontecimientos, la cuestión pasa a ser otra: cuál es el tratamiento mediático de estas informaciones, cómo se incorporan estos asuntos a unas pautas informativas contagiadas de un halo espectacularizante más propio de la programación de entretenimiento que de la función informativa.

El dilema en que los medios se encuentran, como afirman Alberdi y Matas ${ }^{11}$, estriba entre la responsabilidad como informadores y formadores de opinión y su posición empresarial de ofrecer un producto que el público desee y consuma; entre respetar la seriedad de las noticias teniendo en cuenta la gravedad de los hechos y satisfacer su necesidad de atraer al máximo la atención del público, y eso es más fácil de conseguir por la vía del sensacionalismo.

\footnotetext{
${ }^{8}$ Esta campaña estuvo acompañada por la iniciativa DAPHNE, y contó con una dotación de 3 millones de euros.

${ }^{9}$ Esta cuestión está expuesta con claridad en, ASOCIACIÓN PRO DERECHOS HUMANOS. COLECTIVO ABIERTO DE SOCIOLOGÍA. (1999) La violencia familiar. Actitudes y representaciones sociales. Madrid:
}

Fundamentos. pp. 169-175.

${ }^{10}$ En BOSCH, E. y FERRER, V.(2001), "La violencia de género. De cuestión privada a problema social. Intervención Psicosocial”. En Revista de igualdady calidad de vida, vol. 9, pp. 7-19.

${ }^{11}$ ALBERDI, Inés y MATAS, Natalia. (2002) La Violència domèstica: informe sobre els maltractaments a dones a Espanya. Barcelona: Fundació La Caixa. Pp. 242. 


\section{Vías de acción}

Desde el análisis de lo hecho hasta ahora con relación al estudio y formas de acción en la lucha para la erradicación de la violencia contra las mujeres, $\mathrm{Ob} \sim \mathrm{Vio}$ aprecia tres vías de acción que pueden y deben ser complementarias.

\section{Primera vía: recomendaciones a los medios de comunicación a través instituciones u organizaciones}

Cronológicamente la iniciativa fue de las instituciones que sugirieron pautas y recomendaciones tal y como hizo muy tempranamente el Instituto Andaluz de la Mujer que, en 1999, propuso 10 Recomendaciones a los medios de comunicación para el tratamiento de la violencia contra las mujeres ${ }^{12}$, cuyo texto inspira las recomendaciones del Consejo Audiovisual de Cataluña de 2004, revisado en $2009^{13}$.

\section{Las 10 recomendaciones se concretan en:}

PRIMERA. Es importante situar el contenido de la noticia como una violación de los derechos humanos que atenta contra la libertad y la dignidad de las mujeres.

SEGUNDA. Es importante presentar cada agresión, cada asesinato, no como un caso aislado sino como parte de la violencia generalizada contra las mujeres. TERCERA. Es importante realizar un seguimiento en los casos publicados y ofrecer noticias positivas de aquellas mujeres que lograron salir de la violencia. CUARTA. Es importante presentar los malos tratos como crímenes o asesinatos, y no como un hecho "pasional".

QUINTA. Es importante relacionar los malos tratos físicos con los maltratos psíquicos, también estos malos tratos dejan secuelas.

SEXTA. Es importante publicar los datos de los agresores, evitando que el anonimato asegure su impunidad.

SÉPTIMA. Es importante explicar la historia de cada víctima de maltrato: número de veces que ha sido maltratada, denuncias impuestas, juicios previos y penas impuestas al agresor.

OCTAVA. Es importante destacar el valor de las mujeres que denuncian malos tratos para no caer en victimizaciones: estas mujeres se enfrentan con valentía a una realidad no deseada.

NOVENA. Es importante promover el rechazo social a la violencia contra las mujeres: el silencio nos hace cómplices.

DÉCIMA. Es importante informar de los recursos públicos existentes, teléfonos de emergencia y acciones a emprender.

${ }^{13}$ El tratamiento de la violencia machista en los medios de comunicación (2010). Barcelona: CAC 


\section{Segunda vía: autorregulación de los medios}

La segunda vía pugna por la autorregulación de los medios mediante directrices profesionales y códigos de conducta que apelan en general a todos los aspectos de la producción audiovisual

\section{Tercera vía: creación de observatorios}

Como tercera vía, Ob Vio cree en la necesidad de la creación de observatorios permanentes que lleven a cabo investigaciones periódicas y propongan acciones que incidan en la atención al tratamiento informativo, que realicen investigaciones y visibilicen el problema, así como que establezcan planes de acción.

La acción llevada a cabo por $\mathrm{Ob} \sim \mathrm{Vio}$ por tanto, se ha enmarcado dentro de esta tercera vía.

\section{4. $\mathrm{E} 1$ proyecto $\mathrm{Ob} \sim \mathrm{Vio}^{14}$}

El proyecto ha tenido como finalidad el establecimiento de mecanismos auditores donde participaran las instituciones académicas, organizaciones no gubernamentales y organizaciones de profesionales, y que adquiriendo la estructura de Observatorio incentivara la participación conjunta de todos los actores del proceso, que canalizara las críticas y las propuestas desde una organización equidistante entre los intereses económicos de los medios y los mecanismos controladores de las instituciones. Se ha buscado, en concreto, crear un observatorio permanente sobre la producción discursiva de RTVA en lo que respecta a la construcción del género en aquellas informaciones cuyo tema central sea la violencia contra las mujeres.

La labor llevada a cabo por Ob Vio se ha centrado en la Radiotelevisión de Andalucía, dado que es el único operador de cobertura autonómica y el máximo responsable en su ámbito de la

14 Se puede acceder a toda la información y detalles del proyecto en http://www.obvio.uma.es 
aplicación de aquellas políticas que fomenten la igualdad y eliminen la discriminación. Complementariamente además, la transmisión de estereotipos y la incorrecta información sobre la violencia de género en los informativos de la RTVA posee un carácter de mayor trascendencia que la transmisión de estos mensajes a través de otros canales privados, dada la audiencia mayoritaria a la que se dirige y las obligaciones contraídas en su Estatuto.

Nuestro interés ha radicado en testear las variables que intervienen en la creación de estos discursos:

- Las variables endógenas: el enfoque sensacionalista, la progresiva espectacularización de las informaciones, el tradicional acercamiento a las masas mediante los sucesos, las acentuaciones luctuosas y morbosas.

- Las variables exógenas, que provienen de la maximización de una serie de formas narrativas que contribuyen a recrear a una serie de personajes y escenarios de la violencia machista, buscando antecedentes y explicaciones que reconstruyen el contexto y los actores en un proceso de extrañamiento que aísla a la víctima y al agresor del resto de sus congéneres, presentándolos como elementos disfuncionales, marginales, con respecto a la 'normalidad': el exceso, la rareza, la otredad, se construyen con mecanismos diversos que abundan en la excepcionalidad, especial y cada vez más frecuentemente, con referencias de clase y estatus social, etnicidad o lugar de procedencia.

Estas pautas de producción contribuyen a aislar el problema de las coordenadas de convivencia, modo de vida, actividad laboral, y estatus socioeconómico que nuestra sociedad considera 'normales'; la representación de víctimas y agresores presenta un panorama caracterizado por la incidencia de fenómenos migratorios, adicciones varias, modos de vida reprobables, familias desmembradas, etc. en una confusión constante de detonantes con causas. 
Frente a esta tendencia, la contra hipótesis estaba ya presente en investigaciones pioneras y comparadas. Así M. Straus ${ }^{15}$ en The international dating violence study demuestra como en treinta países representativos de diferentes realidades culturales y socioeconómicas, los episodios de violencia entre los y las jóvenes se inician durante los estudios universitarios. La investigación francesa Les violences envers les femmes en France ${ }^{16}$ concluye que la violencia contra las mujeres se presenta como algo global y no limitado al ámbito familiar, extendiéndose a la pareja o a la familia como al trabajo o los espacios públicos.

Con todo, las nuevas realidades sociodemográficas y la incidencia generalizada de este problema comienza ya a incidir particularmente en el sesgo que hemos querido destacar en nuestra investigación. Precisamente, las ampliaciones, modificaciones o actualizaciones de las recomendaciones y códigos de autorregulación transitan por esos derroteros. Expresamente el CAC señala que "es contraproducente sesgar la incidencia de los casos de violencia machista hacia grupos sociales concretos, orígenes culturales y circunstancias determinadas, ya que se trata de un fenómeno universal y estructural"17.

Partiendo de ese posicionamiento y para lograr los objetivos mencionados, $\mathrm{Ob} \sim$ Vio identificó tres focos sobre los que actuar, que aunque relacionados entre sí, poseen características concretas y acciones diferenciadas que han sido ejecutadas.

El primer foco ha tenido como objetivo la observación, recopilación y sistematización de todas la informaciones sobre violencia-mujeres

${ }^{15}$ Junto a Gelles y Steinmetz (1980), fue uno de los pioneros en investigar y sacar a la luz pública el tema de la violencia contra las mujeres en los años 7080. Los resultados de su encuesta sirvieron de modelo para que muchos otros países iniciasen investigaciones sobre violencia contra las mujeres.

${ }^{16}$ JASPARD, M., y otros (2003). Les violences envers les femmes en France. Une enquete nationale. Paris: La Documentation Française,

${ }^{17}$ Recomendación $n^{\text {o }} 10$. El tratamiento de la violencia machista en los medios de comunicación. Barcelona: CAC, 2009 
atendiendo especialmente a la variable identitaria (migrantes, gitanos/as,...). El resultado del mismo, además de haber sido uno de los materiales de análisis fue la creación de un banco audiovisual accesible para otros investigadores ${ }^{18}$.

El segundo foco ha sido el de análisis propiamente dicho, y ha cumplido el objetivo de conocer cuál es el tratamiento que se le da a estos mensajes, observando en ellos además del propio texto como resultado, cómo influyen las rutinas productivas del medio.

El tercer foco ha sido el de proyección social e indagación de las tendencias, y ha buscado fomentar la participación de instituciones, organizaciones sociales, ciudadanos y ciudadanas, que desarrollen propuestas, denuncien prácticas, y, en definitiva, generen sinergias que prevengan la violencia contra las mujeres y actúen contra ella.

\section{Acciones y conclusiones de $\mathrm{Ob} \sim \mathrm{Vio}$}

Atendiendo a los tres focos de acción planteados y a los objetivos, la metodología utilizada, como se ha mencionado, ha tenido tanto carácter cuantitativo como cualitativo, utilizándose diferentes técnicas de producción, recogida de información, y propuestas de intervención.

En primer lugar, se ha estudiado el contenido de los mensajes emitidos a través del análisis crítico del discurso (ACD) de la muestra. En segundo lugar, se ha analizado cuáles son las rutinas productivas que influyen en la elaboración de las noticias a través de las entrevistas en profundidad llevadas a cabo a los responsables de sección y coordinadores de equipo, así como en las encuestas realizadas a los realizadores, cámaras, montadores y demás miembros de los equipos de producción de las noticias. En tercer lugar, se ha pretendido dar luz acerca de la percepción de la ciudadanía acerca del modo de construcción de estos mensajes a través de grupos de

${ }^{18}$ www.obvio.uma.es 
discusión. Y por último, se ha complementado todo ello con la visión de expertos en la materia mediante el método DELPHI.

\subsection{Análisis Crítico del Discurso (ACD) ${ }^{19}$}

Tres han sido las conclusiones fundamentales a las que hemos llegado tras este análisis.

Atendiendo a la estructura de los mensajes, se ha observado cómo e independientemente del caso concreto, se observa una repetición sin diferenciación entre los diferentes casos. Todos ellos se muestran bajo el mismo modelo de construcción, lenguaje, tipos de fuentes, imágenes (que en muchos casos llegan a ser morbosas). No se particulariza en cada caso concreto dotándolo de identidad propia, y se presentan como otro caso más, lo que a la postre provoca un efecto anestesiante que aleja a la sociedad de este problema. Las víctimas quedan reducidas a meras cifras, no a mujeres con rostro, lo que dificulta la empatía con ellas, y paraliza la reacción de la ciudadanía al percibirse como algo que por lo frecuente y a pesar de su gravedad, forma parte natural de nuestras sociedades.

En lo que respecta a las fuentes, a quiénes toman la palabra, a quiénes se muestran como organizaciones preocupadas por el tema, se produce un hecho paradójico: al contrario de lo que ocurre con la mayoría de las informaciones en el que el uso de la fuente masculina es predominante (existen numerosos estudios que muestran que las voces de los expertos aparecidos en las noticias son principalmente masculinas), en estos casos la aparición de hombres es prácticamente inexistente. Ello provoca una presentación del problema como algo únicamente preocupante para las mujeres, como una temática asociada a lo femenino, y por extensión, por lo que ellas han de luchar. Se echa en falta una representación más equilibrada en la que

\footnotetext{
${ }^{19}$ Puede consultarse en detalle el análisis llevado a cabo en el capítulo segundo de este libro titulado La actualización de los códigos de buenas prácticas en los medios audiovisuales: una necesidad para la lucha contra la violencia machista, escrito por Antonio A. Caballero Gálvez
} 
se impida la transmisión de la idea de que esta lacra es un problema femenino, y no un problema social en el que tanto mujeres como hombres han de implicarse para su erradicación y cuyas consecuencias afectan a la sociedad en su conjunto.

Por último, también se ha concluido que existe una tendencia a la utilización política de estas informaciones. Se observa cierta instrumentalización de las mismas mostrando voces institucionales y actores políticos que denuncian y que hacen gala de la necesidad de atajar el problema, apariciones que en cuanto a número exceden las acciones reales que luego, y en el ejercicio de su responsabilidad, llevan a la práctica. Asimismo se silencian o tienen poca representación las acciones ejecutadas por las diferentes asociaciones, organizaciones y activistas que realizan labores diarias de prevención, atención y acompañamiento de las víctimas.

\subsection{La influencia de las rutinas productivas en la elaboración de las informaciones}

Pero para poder ir más allá e intentar explicar por qué los mensajes se construyen de la manera que hemos esbozado, es necesario también atender a otros condicionantes, entre los que tienen un papel fundamental las rutinas productivas a las que están sometidos los profesionales en la elaboración de los mismos. Para conocerlas se han llevado a cabo entrevista en profundidad con diferentes responsables de las redacciones y cuestionarios dirigidos a los periodistas.

\subsubsection{Entrevistas en profundidad}

El objetivo de estas entrevistas ha sido conocer las dinámicas de producción y realización de las noticias sobre violencia machista por parte de los servicios informativos de Canal Sur. El informe completo de las entrevistas se encuentra disponible en el enlace: http://obvio.uma.es/index.php/entrevistas

La RTVA cuenta desde el año 2011 con un Código contra la Violencia Machista realizado por el Consejo Profesional de Redacción de Canal Sur TV y Canal Sur 2, en el que se indican una serie de 
recomendaciones sobre el tratamiento informativo para la elaboración de estas noticias. A través de estas entrevistas se ha pretendido dar luz acerca del conocimiento del propio código entre los trabajadores y la aplicación del mismo.

El código nace de la necesidad de dar un tratamiento de especial cuidado a las noticias de violencia machista. En 2010, bajo la vicepresidencia de $\mathrm{M}^{\mathrm{a}}$ Teresa Fernández de la Vega, se reunieron todos los directores de televisiones del territorio nacional para consensuar un enfoque común sobre su tratamiento. Desde ese momento, RTVA comenzó a seguir las pautas que se marcaban desde el gobierno, y finalmente culminó la tarea con la creación, a través de su Consejo Profesional, de la Guía de violencia de género. En él se incluyen indicaciones que hacen referencia tanto al tipo de imágenes como a los contenidos; en definitiva, a cómo se deben contar y tratar estas informaciones. La guía se encuentra actualmente disponible tanto en el portal web de la RTVA, como en la intranet del propio equipo; además, está impresa en todas las redacciones y centros territoriales.

El código es conocido por todos los trabajadores, desde los redactores hasta los editores, ha sido enviado y publicitado entre ellos, y se han desarrollado cursos de formación. Pero son los editores quienes tienen la responsabilidad final de velar por su aplicación.

La redacción del código es clara, a modo de libro de estilo. El redactor conoce por tanto las recomendaciones, pero es además consciente de que el editor finalmente va a imponer las pautas marcadas en él, por lo que aunque en sentido estricto sean recomendaciones, a la postre son normas de obligado cumplimiento.

Cuando existen conflictos acerca de su aplicación, son los jefes de redacción los encargados de resolverlo y de recordar su existencia.

Según los entrevistados, son pocas las veces en las que no se cumple, y cuando esto ocurre suele ser por un desconocimiento derivado de que se trata de un profesional de reciente incorporación. 
Además de las normas de estilo acerca del tipo de imágenes que se han de grabar, de la terminología que se debe usar, de las fuentes a las que hay que acudir, etc, dentro del código subyace la idea de que en la construcción de las informaciones se debe intentar mostrar la existencia de que es posible acabar con la violencia machista, lo denominado "fomento cívico". Así, se indica que la violencia de género debe abarcarse no sólo desde el punto de vista de las victimas, ni únicamente cuando se produzca un asesinato, sino también desde otras perspectivas: judicial (normas regulatorias), policial, centros de acogida u organizaciones de acompañamiento, etc...

Preguntado a los entrevistados acerca de cómo ven en general el tratamiento informativo de la violencia machista en nuestro país, sobre las dificultades con las que ellos se encuentran a la hora de aplicar el código, y sobre cuáles son las mejoras que en él incluirían, el aspecto que más salió a la luz fue el de la gran diferencia existente entre el tratamiento informativo dado por las televisiones públicas frente al de las privadas: mientras las públicas se rigen por un código deontológico cuya aplicación no consideran censura, en las privadas argumentan que prima el morbo, y, derivado de ello, abogan por la creación de un código regulador que homogeneizara el tratamiento informativo de las noticias de violencia de género en cualquier medio audiovisual.

Otro aspecto importante es el que tiene que ver con la formación, los entrevistados coinciden en que sería necesario poder contar con periodistas especializados en género, no solo para que el tratamiento de las informaciones fuera el adecuado, sino para que la propia construcción de la noticia estuviera enfocada hacia objetivos más amplios como la educación y la sensibilización al respecto de esta lacra.

El mayor enemigo para la aplicación del código lo encuentran en la celeridad y la urgencia propia en la emisión de las noticias, pero insisten en que en los casos en los que no se ha podido obtener la información necesaria o las imágenes adecuadas, la noticia debiera emitirse de forma escueta dejando la ampliación de la misma a las siguientes ediciones. 
Con respecto a las mejoras que el código podría incorporar, señalan que realmente no sería necesaria una reactualización del mismo porque, a su juicio, se adapta a situación actual. En esa línea, están en desacuerdo con la aseveración realizada por Consejo Audiovisual de Andalucía (CAA) en su último "Informe sobre la Presencia de la Violencia de Género en los Informativos de las Televisiones Públicas Andaluzas", que habla de la existencia de un efecto narcotizante ante la reiteración de estas informaciones. Al contrario, ellos consideran que el tratamiento dado por Canal Sur a cada caso es individualizado y por lo tanto cumplen una labor de sensibilización mucho más allá del mero aporte de cifras de víctimas.

En lo que a presencia y voces que aparecen en los mensajes, sí han señalado la necesidad de incluir un mayor número de voces masculinas pronunciándose contra la violencia machista, para que no se traslade la idea de que es un problema solo de mujeres, sino de que es un problema social que necesita de la implicación de toda la ciudadanía. Sin embargo, matizan que en cuanto al tratamiento más general, la información debe seguir centrándose en las mujeres, que son las víctimas, y que el aspecto masculino de las noticias debe centrarse en el resultado de las penas impuestas a los maltratadores y no en los cursos de rehabilitación, ya que su funcionamiento y resultados aún no están del todo demostrados.

Sin embargo y como conclusión, a pesar de esta enunciación general, sí que ven de forma clara la necesidad de incrementar el número de informaciones complementarias, reportajes, documentos de investigación, etc., cuyo contenido vaya más allá de la agresión o muerte de una mujer, emitiendo mensajes de concienciación y divulgación.

\subsubsection{Encuestas}

Para contrastar los resultados obtenidos tanto en el análisis de la muestra de las noticias, como en las entrevistas en profundidad con los responsables de las redacciones, y que ya hemos expuesto en apartados precedentes, se realizaron encuestas en todos los servicios informativos de Canal Sur Televisión, tanto locales como el servicio 
central (regional). El informe completo, así como los gráficos y tablas de porcentajes se encuentran disponibles en el siguiente enlace: http://obvio.uma.es/index.php/cuestionario

Los resultados nos revelaron una serie de datos que a veces entraban en contradicción con lo manifestado por los responsables en las entrevistas en profundidad.

Es especialmente importante destacar que algunos de los encuestados no conocen la existencia del "Código y tratamiento informativo de CSTV para la elaboración sobre VIOLENCIA MACHISTA” (2012), a pesar de las acciones de difusión del mismo que, según nos manifestaron, se acometieron. Aunque sea un número reducido, dada la importancia del tema y del tiempo transcurrido desde su existencia, no debiera haber ningún redactor que no supiera del mismo, por lo que se deberían llevar a cabo acciones periódicas de formación y difusión. Con respecto a ello y según aparece en la encuesta, los responsables últimos de su aplicación son los jefes de sección, por lo que deberían ser ellos además quienes hagan el seguimiento y la supervisión de su aplicación en su redacción y edición, y detectaran el posible desconocimiento por parte de los redactores y editores.

En segundo lugar, respecto al origen de las fuentes empleadas en la elaboración de las noticias, aún existe un pequeño porcentaje de los entrevistados que utiliza a vecinos y amigos como una fuente válida que incluyen en las informaciones. La utilización de estas fuentes, tal y como explicita el propio código, requiere de su identificación, algo que no siempre sucede, hecho también constatado en el análisis de la muestra de noticias. El resultado de ello es una notable pérdida en la rigurosidad y la objetividad de estos mensajes.

En tercer lugar, esta encuesta nos ha revelado que el tratamiento local y regional es distinto. Hacemos una valoración positiva de esta cuestión en cuanto a las noticias locales, ya que su tratamiento cercano favorece la individualización del caso, por oposición a lo que sucede en el informativo regional, donde cada vez más las noticias tienden a homogeneizarse favoreciendo el efecto narcotizante ya mencionado en otros apartados. 
Por último, en cuanto a la información y los datos que se deben incluir en las noticias sobre violencia machista, vuelven a surgir en las encuestas dos de las temáticas más discutidas durante nuestra investigación, y que son la inclusión o no de la información sobre si existía denuncia previa por parte de la víctima, y si es positivo o negativo introducir la variable identidad étnica/cultural.

\subsection{Recepción de la información. Grupos de discusión ${ }^{20}$}

El propósito de la aplicación de los grupos de discusión a esta investigación era obtener detalles acerca de la recepción de estos mensajes por parte de grupos de ciudadanos de diferentes perfiles, para ampliar la perspectiva de los estudios llevados a cabo desde el Observatorio, ofreciendo información complementaria a las demás herramientas metodológicas.

Nuestro interés se centró en el análisis colectivo de las noticias y la capacidad de éstas para revelar los preconceptos de la población en relación con la violencia hacia las mujeres.

En las conclusiones obtenidas referentes a las cuestiones generales sobre el tratamiento informativo, la mayoría de los grupos observaron confusión y falta de claridad cuando se aportaban datos estadísticos (sobre sentencias condenatorias, número de denuncias, etc). Coincidieron en la necesidad de que hubiera un enfoque más explicativo de los datos a fin de procesar mejor las informaciones, y también alertaron del riesgo del efecto narcotizante ante la avalancha de datos. En esa línea además, criticaron que el tono de las noticias era demasiado equidistante o frío con abundancia de lenguaje técnico, lo que en nada favorece la sensibilización acerca del problema.

La legitimidad de las fuentes informativas fue una de las cuestiones cruciales tratadas. A pesar de lo señalado en el código de RTVA,

\footnotetext{
${ }^{20}$ Puede consultarse en detalle el análisis llevado a cabo en el capítulo tercero de este libro titulado Después de las noticias: experiencias con los grupos de discusión en el Observatorio andaluz de violencia machista en los medios audiovisuales, escrito por Concha Barquero Artés
} 
avalado por numerosos expertos, la mayoría de los integrantes de estos grupos aprecian valores positivos en la inclusión de vecinos/conocidos como fuentes informativas acerca de la relación de la víctima con el maltratador, que aunque pudiera ser parcial y malinformada, según su percepción, sensibiliza acerca del problema.

Con relación al papel de los poderes público existe coincidencia acerca de la falta de credibilidad de los discursos que profieren, que luego no se lleva a la práctica con la implantación de políticas públicas adecuadas y financiadas, y catalogan estas intervenciones como meramente propagandísticas.

Asimismo, también se destacó la inconveniencia de la mención a la nacionalidad de los sujetos de las noticias. Consideraron este dato innecesario y expresaron su preocupación porque ello contribuyese a consolidar estereotipos en torno a la violencia machista y su incidencia entre las minorías étnico-culturales.

En el debate que surgió en los grupos pudimos observar, además, el afloramiento de ciertas creencias instaladas acerca de la violencia machista.

La principal convicción compartida acerca del problema fue la falta de voluntad política e institucional de acabar con él, todo ello demostrable en la ausencia de recursos y de acciones educativas y preventivas. Derivado de ello y como hemos mencionado, las apariciones de los representantes institucionales en las informaciones fueron duramente cuestionadas al chocar con una realidad en la que se imponen los recortes en políticas sociales.

Otro de los aspectos en los que observamos una práctica coincidencia en todos los grupos es la valoración de la dimensión pública de la violencia de género, asumiendo la obligación que tiene la ciudadanía en su denuncia. Pero a pesar de este planteamiento genérico, también adujeron las razones por las que en la práctica a veces ello no se lleva a cabo: miedo de actuar como testigo; complicado del proceso y no convicción de que el esfuerzo tenga resultados positivos; 
individualismo; y, por último, pervivencia de la creencia de que la violencia machista pertenece al ámbito privado.

En cuanto a los fundamentos de la violencia machista, todos los grupos apuntaron para explicar la pervivencia de este fenómeno a motivos culturales, históricos y religiosos que están presentes en general, y que además reaccionan con mayor virulencia ante las prácticas emancipadoras de la mujer. Se señaló (sobre todo entre las mujeres) que la educación recibida es la base del mantenimiento de estos patrones machistas y violentos. Asimismo se mostró especial preocupación por la incidencia de la violencia entre los jóvenes, conectándolo con el ideal del "amor romántico" consolidado en la adolescencia.

A pesar de que las estadísticas contradicen tal afirmación, otra creencia fuertemente arraigada fue la de la existencia elevada de denuncias falsas, y se llegó incluso a insistir en una supuesta sobreprotección legislativa de la mujer.

Por último, subrayar sobre todo en los grupos femeninos, la convicción acerca de la complejidad del camino al que se enfrentan las mujeres que denuncian, tanto a nivel institucional como social.

\subsection{E1 análisis de los expertos. Recomendaciones y nuevas prácticas}

El método Delphi, nos ha permitido completar las conclusiones del proyecto, ya que al propio análisis de los mensajes, a las cuestiones derivadas de los emisores de los mismos (rutinas productivas), a la visión de la ciudadanía mediante los grupos de discusión, unimos por último la valoración de los expertos acerca del tratamiento informativo de la violencia machistas en los medios audiovisuales. El informe completo se encuentra disponible en el enlace: http://obvio.uma.es/index.php/delphi

Las cuestiones planteadas a los expertos han venido marcadas por los objetivos del proyecto y se concretaron en seis aspectos: 1) la valoración general de la percepción de las noticias audiovisuales, 2) la 
conciliación entre la frialdad de las cifras y la necesidad de empatía con las víctimas, 3) las fuentes empleadas en la elaboración de la información, 4) la instrumentalización política o no de los poderes públicos, 5) la arraigada creencia de las conocidas como "denuncias falsas" y 6) las recomendaciones acerca del formato adecuado para la correcta transmisión de estas noticias.

Con respecto a la percepción de las noticias televisivas sobre violencia machista y su grado de presencia, todos coinciden en el tono sensacionalista que predomina siempre tras ellas. Patricia Laurenzo indica que el entorno económico y social en el que se producen los actos de violencia debería estar presente, y además considera que "el verdadero problema de la televisión es que se dan por satisfechos con informar sobre los episodios violentos con el correspondiente teléfono de ayuda a las mujeres maltratadas, pero paralelamente siguen emitiendo programas con gravísimos prejuicios de género que nadie cuestiona y que sostienen la imagen de mujeres sumisas, destinadas únicamente al matrimonio y la crianza de niños."

José Manuel Blasco destaca como avance el hecho de que existan decálogos específicos, pero incide en que el tratamiento informativo "no realiza un análisis del fenómeno social [...] la víctima sólo es un número más, y el agresor un 'desviado' más."

Jesús García, critica que la violencia machista solo aparece en los medios cuando hay una agresión grave o una muerte. Para él, "el problema debería ser tratado desde dos aspectos: su alta prevalencia y la cronicidad, y su vinculación con otras formas de control machista."

Emelina Galarza pone el acento en el efecto anestesiante de la mera cuantificación en el número de víctimas y en el mal uso del lenguaje que sigue perpetuando concepciones erróneas de este fenómeno, como por ejemplo cuando se habla de violencia doméstica, o cuando se construyen mensajes centrados en la mujer como víctima que además invisibilizan a los agresores o asesinos.

Ante la cuestión de la búsqueda de unos métodos de transmisión conciliadores entre la rigurosidad periodística y la necesidad de 
sensibilización ante la violencia machista, todos coinciden en la máxima de que "lo que no se comunica no existe" y están de acuerdo de que es importante la difusión de la violencia machista a través de los medios audiovisuales. Sin embargo, difieren en cuanto al modo de hacerlo. Patricia Laurenzo y Jesús García consideran que se deberían buscar otros formatos como reportajes o documentales en los que se abordara el tema de manera más extensa y desde diferentes enfoques. En esa línea Ana Bella destaca "los informativos tienen un formato de inmediatez y de rapidez que es imposible que profundicen en las raíces del problema y en informar sobre toda su complejidad"; y si bien constata que el tratamiento informativo ha mejorado en los últimos años, insiste en que "seguimos echando en falta que las mismas noticias de mujeres asesinadas las acaben con el testimonio de una mujer superviviente diciendo que hay salida a la violencia, para que el mensaje que se mande no sea sólo el negativo."

Emelina Galarza aboga por la importancia de la existencia de las noticias en los informativos pero complementada con otros formatos: "los informativos son un formato más a usar como herramienta de sensibilización, prevención y formación. Se puede conciliar, siempre y cuando la noticia se trate con la seriedad, ética y rigor profesional que el tema exige, lo que requiere formación específica en relación al tema violencia de género por parte de los profesionales que trabajen las noticias."

Con relación a lo que los expertos consideran como fuentes legítimas y fiables en las informaciones Patricia Laurenzo asevera que "es importante la información policial y también la que se pueda obtener en los juzgados. Habría que huir de los supuestos especialistas en temas criminales que tanto abundan en la televisión actualmente y cuyos enfoques suelen ser sesgados y poco rigurosos desde la perspectiva penal y criminológica.”. Jesús García Martínez también alerta acerca de la parcialidad que puede suponer el uso de algunas estadísticas que sólo sacan a la luz datos de aspectos demasiado concretos del problema, e insiste en que las fuentes que deben utilizarse sean "fundamentalmente estadísticas tanto de sanidad como de fuentes judiciales". Emelina Galarza apuesta más por las 
asociaciones y expertos y considera que "deben tener más presencia las personas y profesionales especialmente con sensibilización y formación en relación al tema violencia de género: asociaciones feministas, juristas, jueces, magistrados/as, escritores/as, psicólogos/as, sociológos/as, etc.”. Ana Bella pone de manifiesto también la necesidad de la presencia institucional refiriéndose al “Observatorio Violencia del Consejo General del Poder Judicial, la Delegación Gobierno Violencia de Género, el Instituto de la Mujer y por supuesto las voces de las mujeres supervivientes que hemos sido las verdaderas protagonistas."

Con relación a la posible instrumentalización política de la violencia machista dentro de las campañas y los programas de los partidos políticos, la respuesta de los expertos, con mayor o menor intensidad en sus afirmaciones, va en la línea de considerar que a los partidos políticos les ha favorecido el mostrar sensibilidad al respecto y que por lo tanto ello ha determinado que la violencia machista sea un elemento clave dentro de sus agendas.

Sobre la sistemática presencia o alusión en los medios al aspecto de 'las denuncias falsas', los expertos coinciden con la idea de que este dato es un indicador del patriarcado y se usa como una estrategia para obstaculizar el camino hacia la igualdad. Con respecto a este asunto, Ana Bella es tajante "procuradores/as y abogados/as se han influenciado por este tópico, cuando realmente a las mujeres maltratadas nos cuesta denunciar al padre de nuestros hijos, ahora algunos/as abogados/as se han apropiado de ellos para sacar ventaja en los juicios de divorcio". Tal y como ella misma indica "las denuncias falsas en violencia de género suman sólo un $0.01 \%$ del total. [...] Los y las periodistas convierten sentencias, en las que el acusado ha salido absuelto por falta de pruebas, en denuncias falsas. $\mathrm{Y}$ se le da mucho más bombo a noticias en las que se absuelve al maltratador que en las noticias donde le condenan."

Para José Manuel Blasco, los medios son en gran parte responsables de la difusión y transmisión de este equivocado mensaje: "basta con buscar en Google datos sobre denuncias falsas, y son noticias de medios escritos quienes informan de la falacia que supone esa 
generalización. Por tanto los medios actúan aquí como fuente para desmitificar esa generalización, producto también de la maniobra del 'neomachismo' por reestructurarse."

Sin embargo, Patricia Laurenzo apunta hacia otra dirección: "no creo que los medios hayan contribuido a crearlo. Al contrario, la sensación que dejan las noticias sobre violencia de género es un bajo nivel de denuncias por parte de las mujeres."

Por último, hemos querido conocer, además de las noticias propiamente dichas, qué formato consideran adecuado para abordar la violencia machista en los medios audiovisuales, y como resumen que complementa todo lo anterior, Jesús García Martínez recomienda de modo global, formatos en los que "lo fundamental sería centrarse en el control y el dominio por parte del varón y las estrategias desarrolladas para lograr esto, más que en las muertes. Las muertes son la expresión más grave de la violencia de género, pero distan de ser lo más frecuente."

\section{Conclusiones}

Como planteábamos al inicio, el proyecto llevado a cabo pretendía dar luz acerca del sentido que los mensajes que la RTVA difunde acerca del problema de la violencia machista, y cómo estos mensajes pueden ser agentes coadyuvantes, junto con instituciones, organizaciones y ciudadanía, en la sensibilización social y el logro de la erradicación de la misma.

El análisis efectuado nos ha reforzado en nuestra visión inicial acerca de la complejidad de este fenómeno. Los resultados obtenidos muestran dos caras, de una parte una visión, podríamos decir ideal, por parte de los responsables del medio y de las asociaciones, así como en cierta medida de los expertos, acerca de la sensibilidad, de las buenas pautas y la implicación de las instituciones, de la importancia de las acciones que se están ejecutando y de lo que se está alcanzando; y de otra, una visión crítica por parte de los periodistas y de la propia ciudadanía que ponen el acento en los problemas diarios con los que se encuentran en el ejercicio de su 
profesión, y en los obstáculos que cualquier ciudadano tiene (culturales, económicos, judiciales...) cuando se enfrenta a este problema.

De los resultados obtenidos en cada una de las técnicas de investigación empleadas, derivan una serie de acciones que es necesario acometer y evaluar. De ahí la importancia de que la idea inicial con la que se construyó este proyecto y que es la de creación de un observatorio con carácter permanente, pueda llegar a consolidarse a través del apoyo institucional y de la financiación adecuada. La naturaleza abierta y flexible de un observatorio, completada con la creación de un portal web como lugar de encuentro ciudadano en torno a la violencia de género, de acciones formativas y de creación de materiales, exige para su diseño además, la incorporación de diversas disciplinas que, más allá de sencillamente sumar herramientas de análisis, procesamiento y evaluación, atraviesen todo el proyecto para construir un modelo de observación capaz de situar a los investigadores ante los medios no sólo como si estos últimos fueran un objeto de estudio neutro, sino como elementos esenciales en el complejo proceso de construcción de la realidad. En este sentido, un proceso complejo ha de observarse con una mirada múltiple, capaz de desentrañar sus interrelaciones e implicaciones sociales más allá del análisis aislado del hecho en sí mismo, como si éste se produjese ajeno al contexto en el que se gesta y en el que a su vez se integrará y conformará.

Pero no es sólo la corrección metodológica lo que justifica el carácter multidisciplinar y futuro del proyecto una vez concluida esta primera aproximación, sino el hecho de que la investigación universitaria ha de suponer un compromiso con la sociedad en la búsqueda de proyectarse en la misma con la intención de transformarla para mejorarla. El diseño de estrategias e intervenciones no sería completo ni eficaz si se hiciese de manera mono disciplinar, ni si se quedara únicamente en un análisis puntual del fenómeno sin vocación de permanencia en la que cada periodo y la evaluación del mismo reconfiguraran la estrategia, y resultado de ello las herramientas metodológicas y acciones a ejecutar. 
El proyecto expuesto en este artículo y de cuyas conclusiones hemos dado cuenta, no está diseñado exclusivamente para analizar los contenidos de los medios y sus discursos en torno a las cuestiones de género (análisis cualitativo de contenido y análisis del discurso, con el concurso de disciplinas como teoría de la comunicación y teoría feminista, teoría de la cultura de paz). El proyecto también se plantea otros objetivos que pasan inevitablemente por asumir el papel de los medios como mediadores: 1)entender por qué y cómo se construyen y difunden esos contenidos y dónde y cómo se generan (entrevistas en profundidad, compilación y análisis de fuentes bibliográficas y hemerográficas, con el concurso disciplinas como economía crítica de la comunicación, teorías del sistema periodístico y del sistema audiovisual, producción y distribución audiovisuales, programación y contraprogramación, legislación, teoría feminista, teoría de la cultura de paz); 2)intentar desentrañar los procesos de recepción de los contenidos (entrevistas en profundidad y grupos de discusión, encuestas, con el concurso de disciplinas como sociología de la comunicación y psicología social de la comunicación, estudios de recepción, pedagogía, teoría feminista, cultura de paz); 3) diseñar modelos estratégicos y de intervención, y de materiales de difusión y educativos (workshops, think-tanks, seminarios, con el concurso de disciplinas como teoría estratégica de la comunicación, creatividad, diseño gráfico, pedagogía, teoría feminista, cultura de paz).

Para todo ello es necesaria la consolidación del mismo a través de la estructura del Observatorio, un observatorio que cada año establezca los objetivos que se persiguen y cuya determinación derive de la evaluación y resultados de los ejecutados en el periodo anterior. Pero para ello se necesita un apoyo institucional real, más allá que una mera declaración de intenciones.

\section{Referencias bibliográficas}

ALBERDI, Inés y MATAS, Natalia (2002). La Violència domèstica: informe sobre els maltractaments a dones a Espanya. Barcelona, Fundació La Caixa.

http://www.estudios.lacaixa.comunicacions.com/webes/estudis.nsf/ wurl/pfes010cos_esp 
ALLEN, A. (1998) "Power Trouble: Performativity as critical theory", en Constellations, 5, 4. http://www.readcube.com/articles/10.1111/1467-8675.00108 ARIZNABARRETA, Larraitz [et al.]. (2006): Tratamiento de la violencia de género en la prensa vasca. San Sebastián: Universidad de Deusto. BENGOECHEA, Mercedes (2000) "En el umbral de un nuevo discurso periodístico sobre violencia femenina: de la crónica de sucesos a la reseña literaria". En Cuadernos de Información y Comunicación. $N^{0}$ 5. Madrid: Universidad Complutense.

BENJAMÍN, W. (1991) Para una crítica de la violencia y otros ensayos, Madrid, Taurus.

BOSCH FIOL, Esperanza y FERRER PÉREZ, Victoria A.(2001) 'La violencia de género: de cuestión privada a problema social" en: Intervención psicosocial: revista de igualdad y calidad de vida, vol 9, núm. 1. Madrid, Colegio Oficial de Psicólogos, pp. 7-19.

BUTLER, Judith, (1989) Gender trouble: Feminism and the subversion of identity, NY, Routhledge.

BUTLER, J. (1990). "Variaciones sobre sexo y género. Beauvoir, Witting y Foucault", en BENHABIB, S. y CORNELLA, D. (eds.), Teoria Feminista y Teoría crítica, Alfons el Magnánim, Valencia, 193-211. BUTLER, J. (1993) Bodies that Matter. On the discursive limits of 'sex', Londres, Routledge.

BUTLER, J. (2001) Mecanismos psíquicos del poder. Teorías sobre la sujeción, Madrid, Cátedra.

DE LAURETIS, T.(1986). Technologies of gender, Bloomington, Indiana University Press.

DIRECCIÓN GENERAL DE LA MUJER. (2000). Memoria sobre las actuaciones de prevención y erradicación de la violencia contra las mujeres 19961999, Madrid, Conserjería de Servicios Sociales, Comunidad de Madrid.

FAGOAGA, C. (1999) La violencia en los medios de comunicación. Maltrato en la pareja y agresión sexuada. Madrid, Dirección General de la Mujer de la Comunidad de Madrid. 
FERNÁNDEZ, Concepción; REVILLA, Juan Carlos Revilla (Coord. 2007): Violencia en los medios de comunicación. Barcelona: Editorial Hacer.

FRANQUET, Rosa; LUZÓN, Virginia y RAMAJO, Natividad (2007): "La información en los principales medios de comunicación on-line. Estudiar la representación de género" en Zer, 22, 2007, p. 267-282

FRIEDAN, Betty. (1974): La mistica de la feminidad. Madrid: Ediciones Júcar.

GUÍA DE BUENAS PRÁCTICAS PARA PALIAR LOS EFECTOS DE LA VIOLENCIA CONTRA LAS MUJERES Y CONSEGUIR SU ERRADICACIÓN (2002). España. Presidencia de la Unión Europea. Madrid: Ministerio de Trabajo y Asuntos Sociales.

INSTITUTO DE GÉNERO, DERECHO Y DESARROLLO DE ARGENTINA (2008). Decálogo para el tratamiento periodístico de la violencia contra las mujeres. Buenos Aires: Servicio de Publicaciones del Instituto.

INSTITUTO OFICIAL de RADIO y TELEVISIÓN y MINISTERIO de TRABAJO y ASUNTOS SOCIALES (2004): Manual de información en género. Madrid.

INSTITUTO OFICIAL de RADIO y TELEVISIÓN (2002): Mujer, violencia y medios de comunicación: dossier de prensa. Madrid, Foro Nacional RTVE.

http://www.rtve.es/oficial/iortv/Dossier\%20MUJER\%20Y\%20VI OLENCIA.pdf

LORENTE ACOSTA, M (1998). Agresiones a la mujer, Granada, Editorial Comares.

LORENTE ACOSTA, M (2001). Mi marido me pega la normal. Agresión a la mujer; realidades y mitos. Edit. Ares y Mares, Barcelona.

LLORENTE, Francisco (2000): Jornadas sobre medios de comunicación y violencia contra las mujerf.es. Madrid: Instituto de la Mujer.

PATRÓ, Rosa; MARTÍN, Teresa y GÓMEZ, Isabel (2009): Guia para profesionales de medios: programa de prevención de la violencia de género: conocer para cambiar la vida. Alicante: Caja Mediterránea. 
PLATAFORMA PARA LA ACCIÓN.(1995) IV Conferencia

Mundial sobre las Mujeres. Beijing (China), Madrid: Instituto de la Mujer.

SÁNCHEZ ARANDA, J. BERGANZA CONDE, R. y GARCÍA ORTEGA, C. (2003):

Mujer publicada mujer mal tratada. Libro de estilo para informar en los medios de comunicación sobre la mujer. Gobierno de Navarra. Instituto Navarro de la Mujer, Pamplona.

VERA BALANZA, Ma Teresa (2004): "La presencia y el tratamiento de la violencia de género en la prensa: análisis de casos en El País (2001)" en La comunicación: nuevos discursos y perspectivas IV Foro de investigación en comunicación. Madrid: Edipo, pp. 647-653.

\section{Recomendaciones y libros de estilo para el tratamiento informativo de la Violencia de Género}

COLLEGI DE PERIODISTES DE CATALUNYA 2003:

Recomendaciones sobre el tratamiento de la violencia de género en los programas informativos y de entretenimiento en los medios de comunicación: calendario 20042005. Barcelona, Consell de la Informació de Catalunya, Consell de l'Audiovisual de Catalunya. htpp:/ / wmw.cac.cat

OBSERVATORI DE LES DONES EN ELS MITJANS DE COMUNICACIÓ. Decàleg per a una millor representació de les dones en els mitjans de comunicació (octubre de 2010)

http://www.observatoridelesdones.org/remaginat/reimaginat dones. $h$ $\underline{t m l}$

FEDERACIÓ INTERNACIONAL DE PERIODISTES, LA UNESCO I LO-TCO. Instalar el equilibrio. Igualdad de género en el periodismo. Manual sobre periodisme amb perspectiva de gènere. http://unesdoc.unesco.org/images/0018/001807/180740s.pdf

PORTRAYING POLITICS. A Toolkit on Gender and Television. Manual sobre el tractament de les dones politiques en la televisió.

http://www.portrayingpolitics.net

EUROMED. Screening Gender Toolkit. http://www.euromednews.org/en/News/Screening-Gender-toolkit-! 
CONSELL DE L'AUDIOVISUAL DE CATALUNYA. La presència de les dones en la informació. Octubre-desembre de 2008. Barcelona: Consell de l'Audiovisual de Catalunya, març de 2009a.

http://www.cac.cat/pfw files/cma/actuacions/Continguts/IST 12 009 Informe pres ncia dones.pdf

CONSELL DE L'AUDIOVISUAL DE CATALUNYA. Valoració del Consell de l'Audiovisual de Catalunya (aprovada en sessió de 18 de marc 2009). Barcelona: Consell de l'Audiovisual de Catalunya, 2009b.

http://www.cac.cat/pfw files/cma/actuacions/Continguts/Valoraci informe pres ncia dones.pdf

CONSELL DE L'AUDIOVISUAL DE CATALUNYA. La presència de la immigració en la informació. Gener-març de 2009. Barcelona: Consell de l'Audiovisual de Catalunya, novembre de 2009c.

http://www.cac.cat/pfw_files/cma/actuacions/Continguts/IST_2_2 009_Informe_pres_ncia_immigraci_.pdf

CONSELL DE L'AUDIOVISUAL DE CATALUNYA. Valoració del Consell de l'Audiovisual de Catalunya sobre la presència de la immigració en la informació. Gener-mary 2009 (aprovada en sessió de 10 de desembre 2009). Barcelona: Consell de l'Audiovisual de Catalunya, novembre de 2009d.

http://www.cac.cat/pfw files/cma/actuacions/Continguts/Valoraci informe Immigraci 101209.pdf

FEDERACIÓN INTERNACIONAL DE PERIODISTAS. Instalar el equilibrio. Igualdad de Género en el Periodismo. Bèlgica, 2009.

PORTRAYING POLITICS. ATOOLKIT ON GENDER AND TELEVISION. http://www.portrayingpolitics.net

UNIÓ DE PERIODISTES VALENCIANS. Noticies amb llaç blanc: manual per a periodistas sobre la violència domèstica. Valencia: Uniò de Periodistes Valencians, 2002. 


\title{
La actualización de los códigos de buenas prácticas en los medios audiovisuales: una necesidad para la lucha contra la violencia machista
}

\author{
Antonio A. Caballero Gálvez \\ Perfil de Google 21
}

\begin{abstract}
— L tratamiento de la violencia machista en los medios audiovisuales es un factor determinante en la lucha contra dicha violencia en nuestra sociedad. Que dicho tratamiento no sea homogéneo en el espectro de medios y formatos audiovisuales actuales hace que esta lucha se disipe y no consiga el objetivo final de los diversos manuales de buenas prácticas: el fin de la violencia machista. A través del análisis crítico de discurso de una selección de noticias emitidas en Canal Sur TV trataremos por una parte de evidenciar todos aquellos aspectos que deben ser tenidos en cuenta en la hora de elaborar este tipo noticias, y por otra parte, realizaremos una serie de propuestas que mejoren y actualicen las prácticas informativas realizadas en la actualidad dentro de los medios audiovisuales: tratamiento de las imágenes, fuentes informativas seleccionadas y promoción de la ayuda a las víctimas.
\end{abstract}

\section{Introducción}

Después de más de treinta años de las primeras estadísticas sobre violencia contra las mujeres publicadas por el Instituto de la Mujer y

\footnotetext{
${ }^{21}$ https:// scholar.google.es/ citations?user=aVZQ9VkAAAAJ\&hl=es
} 
alrededor de más de veinte años de los casos que cambiaron el tratamiento informativo sobre violencia de género como fueron: el caso de Lorena Bobbit, quien amputó el miembro viril de su maltratador en 1993, y especialmente el caso de Ana Orantes, quién fue asesinada en 1997 un mes después de denunciar en un programa de máxima audiencia de Canal Sur la situación de maltrato durante su matrimonio; nos encontramos actualmente en un momento en el que toca interpelarnos sobre por qué los medios siguen cometiendo los mismos errores regulados en los numerosos decálogos de buenas prácticas, publicados hasta ahora sobre el tratamiento de las noticias de violencia de género, para comenzar a denunciar los discursos hegemónicos que siguen controlando las informaciones dadas, así como proponer nuevas herramientas y elementos discursivos que refuercen la comunicación informativa así como la concienciación social sobre la violencia machista. Ya que tal y como se indica en el Consenso sobre la introducción a las causas y soluciones de la violencia psicosexual hacia las mujeres (2000): "los medios de comunicación deberán ponerse al servicio de la educación por la paz." (Bosch Fiol; Ferrer Pérez, 2000: 11).

El objetivo principal del análisis crítico del discurso que vamos a realizar en este texto se centra en conocer cómo el discurso contribuye a la reproducción de la desigualdad y la injusticia social determinando quiénes tienen acceso a estructuras discursivas y de comunicación legitimadas por la sociedad y el cómo se construyen dichas estructuras.

Para la realización de este análisis crítico de discurso de las noticias sobre violencia de género emitidas en la actualidad, hemos hecho una selección de tres noticias emitidas por los Servicios Informativos de Canal Sur Televisión durante los meses de noviembre 2013 y enero 2014.

Las tres noticias seleccionadas responden a tres ítems, ya sean ejemplos repetidos de malas prácticas o aspectos ausentes que consideramos que deberían incorporarse o reforzarse. Estas tres cuestiones están en línea con el objetivo de responder contra los discursos hegemónicos en las noticias sobre violencia de género y las 
relaciones de poder ejercidas entre política y medios de comunicación:

1. La homogenización en el tratamiento de la violencia machista incurre en un discurso anodino alejándose del interés informativo y su relevancia mediática.

2. La ausencia de voces masculinas dentro de la información ofrecida por expertos o agentes sociales contra la violencia machista.

3. El abuso y/o instrumentalización política de la violencia machista a través de los medios de comunicación.

Para el análisis de cada una de las tres noticias hemos tenido en cuenta los siguientes elementos: el lenguaje y las imágenes empeladas; el contexto en el que se localiza; fuentes utilizadas; la representación de la víctima / maltratador (construcción de sus estereotipos); y por último, la presencia de los poderes públicos. Además de los elementos particulares de cada una de ellas.

\section{Análisis crítico de discursos de las noticias sobre violencia machista en Canal Sur TV}

Comenzaremos el análisis con una noticia en la que se recogen algunos de los elementos que deberían de haber sido superados tras más de treinta años de experiencia en el tratamiento audiovisual de este tipo de violencia; como serían el empleo de las fuentes de información oficiales y la no utilización de imágenes explícitas sobre las víctimas de violencia machista.

2.1. Cuarta víctima mortal de la violencia de género en la provincia en lo que va de año. Ciudad Jardín (Málaga). Emitida el 06/11/2013 en CSN1 Málaga

En esta noticia se informa sobre la muerte de una mujer por violencia machista, cuyo asesino posteriormente se suicidó. La noticia se inicia y se cierra con el siguiente titular: "cuarta víctima", una cifra que nos 
conduce a cuestionarnos sobre la pertinencia de enumerar a las víctimas dentro de la información dada en este tipo de informaciones. Por una parte, entendemos que este dato incide en la concienciación por parte del espectador de la dimensión de la problemática, sin embargo, este es uno de los datos a tener en cuenta en la banalización de esta información así como en la despersonalización de la propia víctima. Este hecho reduce a la víctima a un número con el consecuente desapego por parte del espectador.

Podemos dividir esta pieza en dos partes: por una parte, la descripción del crimen y por otra, la concentración política en repulsa por los acontecimientos. Esta dicotomía en sí misma ya marca una división y fractura entre la ciudadanía (y el hecho en sí mismo) con respecto a las instituciones (encargadas de que esto no suceda).

En la primera parte, la mayor parte de la información se corresponde con la descripción minuciosa del crimen, a excepción de la intervención de Estefanía Martín (Coordinadora Provincial del Instituto Andaluz de la Mujer). La descripción es realizada por parte del redactor, quien toma como fuente el testimonio de una vecina de la víctima: "una vecina ha afirmado que la fallecida le había contado que su marido la maltrataba. Según su relato, el hombre la encerraba, la dejaba sin comer, le pegaba y no le daba dinero para mantenerse. Pero como esta vecina no veía luego situaciones de violencia en la calle, no estaba segura de que aquello fuera real". Aunque el Código contra la Violencia Machista de Canal Sur (2010) define en su punto $8^{\circ}$ cómo debe ser el Tratamiento Informativo: "Contrastaremos la información y mencionaremos la fuente, también en el caso de vecinos, familiares, amigos...", consideramos que deberían ser fuentes primarias a suprimir, ya que su contenido distorsiona la información y cubre de amarillismo y sensacionalismo una noticia que se pretende objetiva y firme en la lucha contra la violencia machista.

La urgencia y rapidez en dar una información no debe primar sobre la solvencia y seriedad de este tipo de noticias, aún así, en el caso de ser necesario el uso de estas fuentes, hay detalles superfluos como que "el hombre la encerraba, la dejaba sin comer, le pegaba..." que deberían suprimirse ya que amplía el grado de victimización de la fallecida sin 
ser un hecho contrastado, en un intento por llamar la atención de una parte del público que puede sentirse ajeno a este tipo de actitudes.

Por otra parte, el cierre del comentario de la vecina "como esta vecina no veía luego situaciones de violencia en la calle, no estaba segura de que aquello fuera real" conlleva a pensar de nuevo en la tradicional concepción de la violencia machista como un acto doméstico, por lo tanto privado, algo que se supone que tanto las instituciones, como especialmente los medios de comunicación, deberían condenar y denunciar dado que no es una cuestión "privada" sino un problema "social" y por ende, "público".

A continuación, la noticia incluye un fragmento de la intervención de Estefanía Martín (Coordinadora Provincial del Instituto Andaluz de la Mujer), para continuar con la descripción de asesinato. En esta segunda intervención del reportero, se describe detalladamente la muerte tanto del asesino como de la víctima, detalles innecesarios que de nuevo vuelven a incidir en el morbo: "se oyó un golpe seco y quienes se asomaron vieron a un hombre que aparentemente se había tirado de un balcón" "en el interior de la vivienda descubrieron muerta a la mujer que presentaba señales de violencia”.

Todo ello se acompaña de imágenes la brutalidad de las muertes, por una parte la sangre en el suelo de la caída del asesino, y por otra parte, ambos cadáveres, tanto de la víctima como de su asesino. Estas imágenes de nuevo conllevan a dramatismo, ¿es necesario mostrar ambas muertes de forma tan explícita? Ver a los servicios funerarios y las camillas de cadáveres muestran una imagen que lejos de conseguir la complicidad del espectador, reduce el problema a la muerte y aleja la concepción de "violencia machista" como un acto que no únicamente tiene como resultado la muerte.

De nuevo, aparece la presentadora para informar del teléfono 016 y da paso a la concentración de las autoridades en el Ayuntamiento de Málaga, a partir de la entrada "la violencia de género ha sido rechaza en la calle”, algo que no se corresponde con las imágenes que vienen a continuación que corresponden a las autoridades de Málaga y su provincia en la puerta del Ayuntamiento guardando un minuto de 
silencio. La identificación de la "calle" con las autoridades no es sólo falsa sino que además reduce la oposición en la calle con la concentración de un pequeño grupo de autoridades.

Visualmente, las imágenes muestran un colectivo sin identificar que se les otorga la categoría de "autoridades" sin mostrar ningún tipo de cartela o faldón identificativo que informe al espectador de los reunidos, sino simplemente se les muestra en conjunto como parte de un todo "autoridad", cuya legitimidad -e insistiendo en su no identificación- queda en entredicho.

Por lo tanto, en este caso podemos identificar tres cuestiones que conducen al efecto narcotizante de este tipo de noticias en los medios audiovisuales: el uso de las fuentes no oficiales, lo explícito de las imágenes y el conjunto de "autoridades" políticas sin identificar.

En cuanto a la presencia política dentro de esta noticia, y su uso mediático, aparece en dos partes principales: por una parte las declaraciones de Estefanía Martín (Coordinadora Provincial del Instituto Andaluz de la Mujer) y por otra, la concentración de autoridades en la puerta principal del Ayuntamiento de Málaga. Las palabras de Estefanía Martín se reducen a una serie de cifras que caen en el reduccionismo numérico al que apuntábamos al inicio de este análisis, más concretamente su discurso se reduce al número de denuncias "en este primer trimestre ya han sido 3091 denuncias que teníamos en la provincia de Málaga"; "una de cada cuatro mujeres sufren violencia machista"; y "este último asesinato se une a esa tendencia desgraciadamente que tenemos de mujeres que no llegan nunca a denunciar". Ante esta insistencia sobre la relevancia de la denuncia como única "vía de eliminación de la violencia machista", consideramos que los poderes públicos, y en nuestro caso los medios de comunicación, deberían, por una parte, informar sobre las consecuencias y el procedimiento de la denuncia, y por otra, y más importante, evitar presentar "la denuncia" como única acción contra la violencia machista, una afirmación que posiciona a la víctima como única y última responsable de su propio maltrato y/o asesinato.

¿Qué aporta realmente a la noticia la concentración de las autoridades 
en la puerta del ayuntamiento? En una lectura simple y básica se entiende que es una muestra de respeto por la pérdida de una vida a consecuencia del machismo, sin embargo, presentada de tal forma, como un conjunto de autoridades, las cuáles no son identificadas individualmente, produce que ese acto se desvirtúe convirtiéndose en un ritual más del modelo informativo más repetido en el tratamiento de la violencia machista donde siempre se les representa de este modo. Consideramos que la voz de estas autoridades se convierte en un factor fundamental, tanto para la imagen de ellos mismos como para la propia información, pero presentadas con voz y nombre y no como un conjunto ininteligible.

\subsection{El cadáver de una mujer ha sido localizado por la Guardia Civil esta mañana cerca de un paraje en Níjar (Almería). Emitida el 13/01/2014 en CSN2 Almería}

La noticia que analizamos a continuación comienza, tal y como lo hizo la noticia anterior, cifrando el número de caso. En esta ocasión, es el "primer caso de violencia machista este año en la provincia", un enunciado que demuestra ser una constante en la muestra. Un factor determinante en la homogenización en el tratamiento informativo de estas noticias. Otra semejanza con la anterior es su división en dos partes: por una parte, la información relativa al asesinato y por otra, una breve recopilación estadística de los casos de violencia machista en Almería. La presentadora introduce la noticia, información del reportero, declaraciones de una personalidad política y de nuevo, cierre con la presentadora.

Las fuentes en esta noticia sí son una fuente oficial: la Guardia Civil. Sin embargo, nos llama la atención la repetición en tres ocasiones de la nacionalidad de la víctima y del asesino por parte del reportero. "Se trata de una joven marroquî"; "se trata de una joven de nacionalidad marroquí de 27 años"; y "se trata de un hombre marroquí de 38 años". El origen no es un factor determinante en la información, ya que no es noticiable. De nuevo, este tipo de datos irrelevantes conllevan al distanciamiento del público con el hecho representado. Que la joven haya desaparecido, que su familia haya tardado diez días en denunciar este hecho, y que tanto ella como su asesino vivieran y 
trabajaran juntos, no es un factor propio de una cultura o etnia determinada sino que es aplicable a toda los sectores sociales y culturales. Por lo tanto, ese dato y especialmente la insistencia de su repetición deberían ser suprimidos en el caso de noticias sobre violencia machista. El contexto además donde tiene lugar el crimen, dentro de la provincia de Almería - uno de los principales puntos de inmigración marroquí en el estado español- desvirtúa el acto violento reduciéndolo a un problema étnico/cultural.

La única presencia política e institucional en este caso es la intervención de Carmen Crespo (Delegada del Gobierno en Andalucía) en la cual, además de dejar claro la nacionalidad de la víctima a quien nombra como "la señora marroquí", termina sus declaraciones alabando a las fuerzas de Seguridad del Estado por encontrar a la fallecida. Retransmitir estos mensajes en un informativo de máxima audiencia desfigura el mensaje proteccionista y de seguridad que debería transmitirse al conjunto de víctimas de violencia machista y de la sociedad en general. Que la Guardia Civil haya encontrado el cuerpo de la víctima no es una actuación de las políticas contra la violencia de género, sino de otras funciones de este cuerpo de seguridad vinculadas a la investigación y búsqueda de desaparecidos/as o resolución de crímenes. La inclusión de una personalidad política dentro de estas noticias es una constante. Estas intervenciones deberían proceder de personas expertas que puedan aportar a la información datos útiles para la lucha contra la violencia de género.

Por lo tanto, detectamos una ausencia de voces expertas en noticias que tratan específicamente de casos de violencia machista y una excesiva representatividad de los poderes públicos.

Tras las declaraciones de la Delegada del Gobierno en Andalucía, el reportero aparece frente a la Comisaría de Policía de Níjar dando cuenta de nuevo de los mismos datos aportados al inicio de la noticia. Una información que, tal y como hemos apuntado, incide en la nacionalidad de la víctima y del asesino, sin aportar ningún dato destacable. 
A continuación, la presentadora cierra la noticia con un recuento de las víctimas: "la muerte de esta mujer rompería los dos años que llevamos en la provincia sin casos de violencia machista con resultado de muerte. Dos años trágicos en este sentido fueron 2010 y 2011 con cinco casos en cada uno. Desde 2010 se está produciendo un descenso progresivo de las denuncias." Este tipo de comentarios lanzan un mensaje esperanzador falso, que no haya habido muerte durante dos años, no significa que no haya habido violencia machista. La gravedad de ambos delitos debe ser la misma en su tratamiento informativo sin distinguir entre resultado de muerte o no, ya que esta cuantificación conduce a mensajes que no se corresponden con la realidad que se presupone que el medio debe transmitir. En vez de tomar datos estadísticos de 2010 o 2011, quizás sería más objetivo si se toman datos actualizados de la situación real en el momento en el que se ha producido el caso.

La información además se acompaña de una serie de imágenes de archivo donde de nuevo aparecen imágenes explícitas de unos servicios sanitarias recogiendo un cadáver cubierto. Si la información dada nos conduce a pensar confusamente en el "buen momento" de la violencia machista, las imágenes responden a la dramatización que suele acompañar este a este tipo de noticias.

De hecho en esta ocasión en concreto, rompiendo con lo establecido en el Código contra la Violencia Machista de Canal Sur (2010), no se informa en ningún momento del Teléfono Contra la Violencia Machista 016. Es por ello que consideramos que el mensaje que se desprende de esta pieza informativa es erróneo en cuanto que focaliza la atención de los espectadores en el descenso del número de víctimas con resultado de muerte desde el 2010 sin dedicar el espacio, que consideramos imprescindible, a la atención y protección de las víctimas.

\section{3 Índice de sentencias condenatorias. Declaraciones institucionales. Emitida el 12/11/2013 en CSN2}

En este caso, la diferencia con las otras dos noticias es que en esta ocasión no trata sobre un caso de violencia machista sino de una 
noticia referida al índice de sentencias condenatorias en Andalucía, en lo que podríamos insertar dentro de la temática de "noticias de divulgación", en este caso de medidas políticas, o incluso, se podría precisar "intenciones" políticas.

Hay dos aspectos a destacar dentro de esta noticia: el número de cifras que se citan y el discurso empelado por cada una de las fuentes representadas. En cuanto al número de cifras, si bien los datos es una información que debe ser utilizada, también hay que tener como se da y a qué tipo de público se dirige. En este caso, comenzamos a enumerar: "seis de cada diez sentencias son condenatorias, el resto absolutorias"; "de las casi 12.000 sentencias en el primer trimestre del año, el 41\% fueron absolutorias, apenas llegan al 60\% las que acaban con condena"; "en los primeros seis meses de este año, en Andalucía se han registrado más de 13.000 denuncias y cerca de 3.000 órdenes de protección, de las que 1.800 fueron aceptadas"; y "en Andalucía se han dictado en los tres primeros meses de este año más de 2.600 denuncias por casos de violencia de género, más del 41\% acabaron en absolución". Más allá de la cantidad de datos y cifras que podrían reducirse, especialmente en un informativo dirigido a un amplio grupo de espectadores, nos llama la atención que estas cifras especialmente hagan referencia al número de sentencias absolutorias.

La noticia es una llamada de atención sobre el alto número de sentencias absolutorias. Si entendemos que las noticias sobre violencia machista deberían ser para sensibilizar a la sociedad, como problema social que es, además de ayudar a víctimas o futuras víctimas, el alarmismo de esta información hace que el mensaje quede totalmente distorsionado, pues si bien el Consejero de Justicia de la Junta de Andalucía, Emilio de Llera, insiste en que deberían agravarse las penas: "hay algunos asesinatos que yo creo que deberían tener un agravante específico, porque se trata no de desprecio del sexo, sino de un atentado a la igualdad entre hombres y mujeres, quizás el más brutal que pueda existir", la reportera, tras estas declaraciones, regresa a los datos del alto porcentaje de condenas absolutorias, de lo que se podría desprender la ineficacia de la justicia en este tipo de casos y por lo tanto, la desprotección de las víctimas. 
En cuanto a los discursos de las fuentes representadas distinguiremos en las intervenciones políticas, Emilio de Llera (Consejero de Justicia de la Junta de Andalucía) y Silvia Oñate (Directora del Instituto Andaluz de la Mujer), y la de la única asociación presente, Hilario Sáez (Hombres por la Igualdad). Si bien, Emilio de Llera se cierne a lo que hemos comentado anteriormente sobre la necesidad del agravamiento de las condenas; la directora del Instituto de la Mujer incita a las víctimas a denunciar, sin marcar las pautas que la víctima debería seguir, aunque sí se detiene a la hora de enumerar las virtudes del Instituto de la Mujer, tal y como aquí reproducimos: "insistir también a las mujeres en que a la menor señal, al menor indicio, al menor síntoma, por favor, alcen la voz y acudan a todos estos servicios especializados que ponemos a su disposición, todos los recursos gestionados por profesionales, por grandes profesionales, por profesionales con un amplio bagaje y una amplia trayectoria".

La contrapartida la pone el representante de la asociación Hombres por la Igualdad quien alude directamente a los recortes en materia de violencia de género por parte de las administraciones debido a la crisis económica: "había unos recursos que nos permitían atenderlo de manera temprana y esos recursos se están desmontando. $\mathrm{Y}$ en segundo, lugar había unas campañas y un énfasis en la prevención que ahora están siendo arrasadas y olvidadas por otros problemas que se consideran más importantes".

La dicotomía presentada por ambos grupos de fuentes es clara; mientras las instituciones se limitan a vislumbrar las cosas que se podrían hacer o dar consejos a las víctimas, sin aclarar las repercusiones reales que ello conlleva, el representante de la asociación achaca como parte de la situación actual en materia de violencia machista a los recortes sufridos en los últimos años, tanto en las campañas como en los programas de prevención.

La pluralidad en las fuentes empleadas es un factor determinante a la hora de determinar el grado de neutralidad de un medio de comunicación. En este caso, y por la noticia que analizamos, debemos considerar que tanto el discurso institucional como el asociativo (o no gubernamental) están presente, y de hecho, de forma crítica. Ya que 
es importante condenar la violencia de género, sabiendo que esta violencia es fundamentalmente masculina, y que es un atentado a los derechos de las mujeres que como tal debe ser intolerable. Uno de los aspectos más destacados por Luis Bonino Menéndez para acabar con ello sería: "primero, visibilizarla en todas sus formas, y no solamente percibirla en los graves casos que salen en los medios de comunicación, -ya que es tanto violencia el maltrato físico como el abuso de la disponibilidad femenina en el hogar- y luego establecer mecanismos de condena social y judicial efectiva para quienes la ejercen.” (Bonino Menéndez, 2000: 34).

Esta noticia, al ser de divulgación, contrasta notablemente en la estructura con respecto a las otras dos noticias analizadas. Otro aspecto a destacar, y que la diferencia es el número de fuentes empleadas, tal y como hemos marcado, así como el tono subjetivo de la presentadora, algo que hace el espectador se identifique tanto con ello como con el propio problema de la violencia machista.

En cuanto a las imágenes, en la noticia se utilizan a parte de los totales de los entrevistados, recursos de archivo. En cuanto al uso de imágenes de archivo, evidentemente la información televisada debe ir acompañada de imágenes, sin embargo, el uso de estos recursos es cuestionable. En este caso, al hablar de las sentencias emplean imágenes de tribunales y juzgados, e incluyen imágenes de detenidos, es ahí donde nos detenemos, ya que consideramos que el uso de este tipo de imágenes puede conducir a la confusión del espectador. Un uso descontextualizado de los detenidos por violencia machista les vincula con una información y/o caso que no les corresponde.

\section{Propuestas para la actualización del tratamiento informativo de la violencia machista en los medios audiovisuales}

Una vez analizadas las tres noticias seleccionadas, y a modo de conclusión, consideramos que el tratamiento informativo de la violencia machista necesita actualizar algunos aspectos de sus códigos empleados. Coincidimos con el "Informe sobre la Presencia de la Violencia de Género en los Informativos de las Televisiones Públicas Andaluzas en 2012" del Consejo Audiovisual de Andalucía tanto en la 
ausencia de voces masculinas como el alarmante efecto narcotizante de las noticias de violencia machista.

Si prestamos atención a la presencia de voces masculinas en estas noticias, en la muestra analizada tan solo hemos encontrado la inclusión de la asociación Hombres por la Igualdad, el resto han sido asociaciones vinculadas a mujeres. Esto conduce al pensamiento de que la violencia machista es un problema a resolver y solucionar por parte de la mujer, cuando esta idea debería ser la inversa, es un problema a corregir y solventar también por el hombre. Tener en cuenta este factor podría determinar la recepción actual de estas noticias.

La homogenización de las noticias de violencia machista, especialmente las noticias sobre "casos", que además son las más numerosas, es una constante. El uso de la misma estructura y tratamiento hace que todos los casos parezcan los mismos, lo que provoca el desinterés del espectador y la repetida idea de "un caso más".

Cada víctima es única, y por lo tanto, su tratamiento debería tratarse con sus propias particularidades y especificaciones. Esta homogenización no sólo se refiere a la estructura sino además al tipo de lenguaje e imágenes utilizadas, así como las fuentes. Se recurre antes a los poderes públicos que a las asociaciones u organizaciones no gubernamentales, un hecho apreciable a lo largo de la muestra. Del mismo modo, aunque en el propio Código de Buenas Prácticas de Canal Sur marca las imágenes que pueden incluir o no, hay veces que esto no se tiene en cuenta, y aun así, hay cierto tipo de imágenes que deberían suprimirse, como los cadáveres cubiertos y las puertas, portales y edificios donde han sucedido los homicidios.

El tercer y último aspecto que hemos considerado que era necesario investigar a la hora de realizar el análisis, era la posible instrumentalización política de la violencia machista por parte de los poder públicos y su cobertura por parte del ente público Canal Sur. Aunque no hemos percibido ningún tipo de mal uso de la violencia machista por parte del propio medio, sí que hemos detectado una excesiva 
presencia de los poderes públicos en detrimento de otro tipo de organizaciones sociales, asociaciones o incluso las propias víctimas. La presencia de estos actores políticos hace que la violencia machista en determinadas ocasiones sea utilizada como medio de promoción de estas instituciones, algo que debería quedar fuera de las propias noticias sobre violencia machista.

\section{Referencias bibliográficas}

BONINO, Luis (2001). Masculinidad, salud y sistema sanitario. El caso de la violencia masculina, ponencia en el seminario Mainstreaming de género en las políticas de salud en Europa. Madrid: OMS.

BOSH FIOL, Esperanza; FERRER PÉREZ, Victoria (2000): La violencia de género: De cuestión privada a problema social en Revista Intervención Psicosocial. Revista de igualdad y calidad de vida, volumen 9, número 1, páginas 7-19.

CALLEJA, José María (2013): La violencia como noticia. Madrid: Ed. Los libros de la catarata.

-(2014): Informar sobre la violencia contra las mujeres. Guía de buenas prácticas para los medios de comunicación. Zaragoza: Prensas de la Universidad de Zaragoza.

Informe sobre la Presencia de la Violencia de Género en los Informativos de las Televisiones Públicas Andaluzas en 2012. Consejo Audiovisual de Andalucía. Disponible en:

http://www.consejoaudiovisualdeandalucia.es/actividad/actuaciones Linformes/2013/07/informe-sobre-la-presencia-de-la-violencia-degenero-en-los-i (12/10/2014)

Código y tratamiento informativo de CSTV para la elaboración sobre VIOLENCLA MACHISTA. RTVA - Radio Televisión Andaluza. Disponible en:

http://www.canalsur.es/resources/archivos/2012/1/31/1328025062 927CODIGO CONTRA LA VIOLENCIA MACHISTA2 .pdf 
Después de las noticias: experiencias con los grupos de discusión en el Observatorio Andaluz de Violencia Machista en los Medios Audiovisuales (Ob Vio)

\author{
Concha Barquero Artés
}

$\mathrm{E}$

L Observatorio andaluz de violencia machista en los medios audiovisuales (Ob Vio en su acrónimo y Observatorio a partir de este punto), con sede en la Facultad de Ciencias de la Comunicación de la Universidad de Málaga, ha venido desempeñando desde octubre de 2013 una doble labor: la primera, de investigación, centrada sobre el tratamiento que este tipo de violencia recibe en los informativos de Canal Sur, la televisión pública andaluza. La segunda, desarrollada en paralelo, de recopilación, clasificación y difusión de materiales, y que se ha concretado en la elaboración de un archivo de noticias audiovisuales y en la producción de contenidos divulgativos propios alojados en la página web del proyecto (http://obvio.uma.es/). Todas estas tareas se alinean con el objetivo central del Observatorio: la reflexión en torno a la producción de mensajes sobre la violencia machista y la eventual aportación de alternativas o propuestas de recomendaciones para la producción de estas informaciones.

En el ámbito de la investigación, desde el Observatorio se implementaron diversas metodologías, tales como el análisis crítico del discurso de una muestra seleccionada de piezas emitidas en los informativos de Canal Sur Televisión; las encuestas, realizadas a los profesionales de los medios de comunicación implicados en la 
producción de estas noticias, o las entrevistas en profundidad a los responsables de los servicios informativos de la citada cadena.

No obstante, si bien los resultados obtenidos a partir de los procedimientos descritos nos han arrojado luz precisa acerca de los distintos patrones del discurso desarrollado en los informativos de televisión, así como de las pautas de producción en las que esos discursos se generan ${ }^{22}$, otra herramienta metodológica cualitativa como son los grupos de discusión brindaba al estudio un elemento clave para comprender la complejidad del fenómeno comunicacional en torno a la violencia machista, a saber, la recepción de la ciudadanía. La flexibilidad de esta dinámica, el entorno distendido y espontáneo que una adecuada práctica de la misma posibilita, la profundidad y los matices que permiten a la expresión de los participantes, entre otros aspectos, la convierten en una técnica idónea para desentrañar no sólo las distintas percepciones acerca de los discursos audiovisuales, sino también para advertir cómo las variables socioculturales relacionadas con la violencia machista influyen en la recepción de estos mensajes.

El propósito de la incorporación de los grupos de discusión al diseño metodológico de la investigación radicaba por tanto en la obtención de detalles acerca de la recepción de las noticias sobre violencia machista por parte de grupos de ciudadanos, para ampliar la perspectiva de los estudios llevados a cabo desde el Observatorio, ofreciendo información complementaria a las demás herramientas metodológicas. Los objetivos específicos que perseguía la práctica de los grupos de discusión eran los siguientes:

- Conocer la percepción crítica de la ciudadanía acerca de ciertos elementos del discurso informativo sobre violencia machista en televisión, especialmente aquellos cuyo uso y tratamiento

\footnotetext{
${ }^{22}$ Puede consultarse el resumen global del proyecto y de los resultados del Observatorio en el capítulo 1 de este libro titulado Observatorio Andaluz de la Violencia Machista en los Medios Audiovisuales (Ob-Vio). Hacia una propuesta de sensibilización, escrito por Inmaculada Postigo Gómez
} 
centraron el análisis crítico del discurso que el Observatorio elaboró de manera paralela.

-Valorar el sesgo de género en la recepción de estos mensajes.

-Recoger recomendaciones de estilo y propuestas de mejora de los mensajes informativos surgidas de la ciudadanía.

Un fenómeno complejo como el de la violencia hacia la mujer se gesta y consolida a la sombra del encuentro de múltiples factores. La violencia machista se sostiene en componentes culturales, históricos, educativos y sociales, cuya confluencia, perpetuación y, al tiempo, continua adaptación a los nuevos contextos, explica la dificultad de su comprensión y como consecuencia, de su desaparición. Se trata por tanto de una manifestación de profunda desigualdad que vincula a la sociedad en su conjunto y que demanda la reflexión colectiva e integradora de toda la ciudadanía sin distinción de género o condición.

El recurso a los grupos de discusión trataba así de responder a esa causalidad multifactorial de la violencia machista, lógica en la cual los medios de comunicación encarnan un papel crucial como espejos y a la vez conformadores de la realidad social. Si los discursos informativos televisivos sobre la violencia machista albergan, entre otros, patrones sobre las estructuras y valores sustentadores de la misma, los cuales el análisis crítico del discurso contribuía a desvelar, del diálogo entre la ciudadanía y estos discursos podían surgir reflexiones dignas de interés acerca no sólo de estos mensajes, sino muy probablemente de la valoración social del fenómeno mismo de la violencia, como más tarde veremos. Intuíamos por tanto que la dinámica de los grupos de discusión se podía convertir en una especie de termómetro de una atmósfera social, algo así como una fotografía libre y cualitativa del actual ánimo de la población andaluza frente a la violencia machista.

Así, determinamos que los grupos habían de estar compuestos por ciudadanas y ciudadanos residentes en Andalucía, correspondientes con la diversidad social y demográfica de la comunidad. Más allá de su probable condición como miembros de la audiencia de los 
informativos de Canal Sur, era la heterogeneidad de sus perfiles la que nos interesaba. Para ello se decidió organizar 6 grupos de discusión atendiendo a dos criterios diferenciadores: el de sexo y el geográfico, con objeto de que este último atendiera a aquella complejidad sociodemográfica.

La diferenciación por sexos respondía a la naturaleza misma del tema en cuestión, la violencia machista. Después de meditarlo, los investigadores del Observatorio concluimos que separando a hombres y a mujeres en cada uno de los grupos evitaríamos más fácilmente cualquier clase de cohibición o condicionamiento de la libre opinión que la presencia de participantes de otro sexo pudiera acarrear. Cabe señalar en cualquier caso que fueron varias las sesiones en las que los colaboradores expresaron su deseo de celebrar otra reunión, una en la que se diesen cita participantes de distinto sexo, con el fin de poner en común y debatir lo que, en estos casos preveían, serían perspectivas frecuentemente enfrentadas sobre el fenómeno de la violencia machista y su tratamiento informativo. Desde el Observatorio tomamos nota de la sugerencia para una ocasión posterior.

Con respecto al criterio geográfico, diferenciamos tres ámbitos de celebración de las reuniones: uno eminentemente urbano, otro correspondiente a una ciudad media en la que coexistieran actividades y dinámicas propias del medio urbano y rural, y otro estrictamente rural. Así, teniendo en cuenta el número de habitantes y la distribución entre la Andalucía Oriental y Occidental, celebramos dos grupos de discusión (uno de hombres y otro de mujeres por separado) en cada una de las siguientes localidades: Málaga (568.479 habitantes), en cuya Universidad tiene sede el Observatorio; Chiclana (82.212 habitantes), en la provincia de Cádiz, y Gilena (3.897 habitantes), en la provincia de Sevilla. Las sesiones de Málaga se celebraron los días 7 y 8 de abril de 2014, las de Chiclana el día 2 de junio y las de Gilena el 3 de junio del mismo año.

En cuanto a la composición de cada grupo, establecimos un mínimo de 6 y un máximo de 10 participantes (o colaboradores con la investigación), un número que estimábamos favorecería el diálogo y la 
puesta en común de distintas posturas conservando la agilidad de las sesiones. En la búsqueda de la complementariedad de puntos de vista y experiencias desde una perspectiva intergeneracional apostamos por abarcar un amplio rango de edades, desde los 16 años en adelante sin límite de edad, no habiendo superado los 73 años ninguno de los participantes. De la misma manera, con la finalidad de compartir visiones y construir colectivamente propuestas, contemplamos la diversidad en el nivel formativo de las personas participantes, así como en la situación laboral del momento.

Las sesiones, de una hora aproximada de duración, fueron moderadas por dos de los miembros del equipo de investigación y grabadas con videocámara para facilitar la posterior transcripción y análisis de los datos. Se estructuraron en torno al visionado de 3 piezas informativas, correspondientes a las noticias que se sometieron al análisis crítico del discurso. En adelante nos referiremos a cada una de las piezas con el respectivo título entrecomillado que le asignamos para su estudio:

-CSN1 Local Málaga. Emitida el 06/11/2013. Noticia “Caso Ciudad Jardín".

-CSN2 Autonómico. Emitida el 12/11/2013. Noticia "Sentencias condenatorias".

-CSN2 Local Almería. Emitida el 13/01/2014. Noticia “Caso Níjar".

La primera y la última de estas noticias daban cuenta de sendos feminicidios, perpetrados en el caso de Málaga horas antes de la producción de la pieza y con unos meses de anterioridad en el caso de Nijar (el cuerpo de la mujer había sido además objeto de desaparición por su asesino y su hallazgo había desencadenado la resolución de la investigación policial). Ambas piezas reunían rasgos arquetípicos de las de su clase en los informativos de Canal Sur, pero también contaban con algunas características propias que habían contribuido a su selección. Algunos recursos narrativos, visuales y meramente informativos de "Caso Ciudad Jardín" habían llamado nuestra atención, y presumíamos que también podían como poco ser 
llamativos para los participantes en los grupos de discusión: la utilización secundaria (en estilo indirecto) del testimonio de una vecina de la mujer asesinada como fuente informativa; el contenido mismo de ese testimonio, que daba crédito a comentarios no contrastados sobre la situación de la pareja en cuestión, y la utilización de planos detalle del fragmento de pavimento donde había impactado el cuerpo del asesino suicida, entre otros recursos, planteaban cuestiones de claro orden ético y formal. Por su parte, la reiterada mención a la nacionalidad marroquí tanto de la mujer asesinada como de su asesino estuvo detrás de la selección de la noticia "Caso Níjar".

La segunda de las noticias tenía un cariz diferente. Sin la urgencia de la cobertura informativa de un asesinato o una agresión machista, la pieza "Sentencias Condenatorias" respondía a la vocación de otra buena parte de las informaciones sobre este tipo de violencia recogidas en los noticiarios de Canal Sur, esto es, aquellas piezas dedicadas al análisis, profundización o ampliación de las informaciones sobre el fenómeno de la violencia machista. Con una orientación por tanto más divulgativa, "Sentencias Condenatorias" recogía datos estadísticos e intervenciones de representantes institucionales y organizaciones alrededor de la actuación de la justicia y la situación de los procesos por violencia machista en los tribunales andaluces.

Todas las sesiones de los grupos de discusión siguieron el mismo esquema: tras una breve presentación introductoria del Observatorio, se procedió a la reproducción de la primera de las noticias, después de la cual se permitió a los participantes comentar y debatir los aspectos del discurso más destacados a su juicio, y así sucesivamente con el resto de piezas. Los moderadores se encargaron de guiar la dinámica hacia los temas de interés del Observatorio siempre que se hizo necesario. No informamos en ningún caso del contexto de los hechos relatados en las piezas informativas, ni del orden de aparición de estas piezas en la edición del informativo, o del resto de contenidos relacionados que pudieran haberse emitido en el mismo. Nuestro interés se centró en el análisis colectivo de las noticias y la capacidad 
de éstas para revelar los preconceptos de la población en relación con la violencia hacia las mujeres.

En este sentido, en el desarrollo de cada sesión se hicieron patentes ciertos intereses y surgieron demandas por parte de los participantes que superaban los límites de una mera descripción o interpretación colectiva de los discursos informativos, y también nuestras propias expectativas. De esta manera, tras la transcripción y análisis de los datos registrados en las sesiones, desglosamos las principales constantes, las líneas temáticas que proponíamos por parte del Observatorio y las aportaciones más significativas manifestadas de manera espontánea por los distintos grupos. Estas constantes conforman un armazón de 4 categorías principales en las que organizamos en adelante el texto y que atestiguan lo discutido en cada uno de los citados grupos:

-Tratamiento informativo de las noticias seleccionadas: se refiere a las valoraciones generales de las piezas (en calidad, claridad, tono y estilo), haciendo especial hincapié en la terminología utilizada, las fuentes recurridas, la evaluación de la existencia de denuncia previa por parte de la mujer objeto de la violencia, así como la valoración de los distintos perfiles representados.

-Percepción sobre la violencia machista: bajo este epígrafe hemos identificado consideraciones generales sobre este tipo de violencia, incidiendo en la situación jurídico-legislativa, las causas de la violencia y la dimensión pública de la misma, manifestadas al hilo del debate en torno a las noticias.

-Medios de comunicación y violencia de género: en este punto recogemos la evaluación general de los participantes acerca de la aproximación que los medios realizan sobre la violencia machista.

-Recomendaciones específicas: propuestas de mejora de las prácticas informativas sobre violencia machista sugeridas como conclusión por los asistentes a las sesiones.

Detallamos a continuación las conclusiones generales que sobre cada una de las categorías extrajimos del análisis pormenorizado de los 
datos de los distintos grupos de discusión. Haremos referencia a cada uno de estos de acuerdo con la siguiente nomenclatura:

\author{
-Grupo de hombres de Gilena (Sevilla): GH \\ -Grupo de mujeres de Gilena (Sevilla): GM. \\ -Grupo de hombres de Chiclana (Cádiz): CC \\ -Grupo de mujeres de Chiclana (Cádiz): CM \\ -Grupo de hombres de Málaga: MH \\ -Grupo de mujeres de Málaga: MM
}

\title{
1. Tratamiento informativo
}

Por lo que respecta a las valoraciones generales del tono, uso de recursos y precisión informativa de las noticias mostradas, 5 de los 6 grupos destacaron espontáneamente la confusión y falta de claridad en los datos estadísticos aportados en la noticia "Sentencias Condenatorias", que repasa los porcentajes de denuncias presentadas y sentencias condenatorias y absolutorias de los procesos judiciales por violencia machista. Los participantes tendían a interpretar de manera ambigua la información, sin ser capaces de concluir si las cifras facilitadas estaban relacionadas con una determinada aplicación legislativa, irregularidades en el cumplimiento de los procedimientos u otras razones de carácter social o cultural. Se demandó por tanto en todos los casos un enfoque más explicativo, frente a uno de tipo meramente estadístico, a fin de procesar mejor las informaciones. Los participantes en el grupo $\mathrm{MH}$ alertaron además del riesgo de estandarización de las noticias que podría conllevar un exceso de aportación de datos, aparejado con una indeseada y consiguiente insensibilización de la audiencia.

Abundando en la correlación entre el impacto de las noticias y determinadas prácticas informativas, los grupos $\mathrm{CH}, \mathrm{CM}$ y $\mathrm{MH}$ reflexionaron sobre el uso de los recursos expresivos. Los participantes de estos grupos coincidieron en calificar de aséptico el tratamiento narrativo de la información, característica que fue 
claramente reprobada. Las críticas se centraron en la falta de empatía que las noticias podrían generar por un exceso de frialdad en el tono y la terminología adoptados por los presentadores y redactores de las respectivas piezas, como coincidieron en señalar con uno de los ejemplos aportados, la expresión "caso de violencia machista con resultado de muerte". Los participantes volvieron en este punto a mostrar su preocupación, al considerar que este estilo informativo no consigue la idealmente perseguida concienciación de la población en torno a la violencia machista.

Los miembros de estos mismos grupos advirtieron no obstante un tratamiento sensacionalista en el uso de otros recursos. Así, y continuando con la redacción de las noticias, el grado de detalle en el relato de los hechos de la pieza "Caso Ciudad Jardín" se calificó de morboso e innecesario. En el orden visual, la explicitud de algunas imágenes de esta misma noticia fue desaprobada de manera general por los mismos motivos, en concreto los planos que mostraban los ataúdes con los cuerpos de la mujer y su asesino y aparentes rastros de sangre en el pavimento.

En cuanto a la terminología empleada, apreciamos un sesgo de género en la preferencia por las distintas expresiones para definir la violencia contra las mujeres:

Dos de los grupos masculinos, $\mathrm{CH}$ y $\mathrm{MH}$, expresaron contundentemente su predilección por la expresión "violencia de género" frente a "violencia machista", ambas utilizadas en las noticias seleccionadas. Dos fueron las posturas desde las que estos participantes explicaron su rechazo a la última, a saber: la primera de las expresiones fue percibida como más inclusiva, mientras que la segunda incita en su opinión a una generalización negativa del género masculino como proclive a la violencia contra las mujeres. La otra razón tiene que ver con la noción de violencia de género manejada por miembros de estos grupos, que consideran que la expresión "machista" no refleja la complejidad de la violencia acaecida en el seno de una pareja. Con todo, el debate en torno a la idoneidad de estas expresiones derivó en algunos casos en una discusión acerca del fenómeno mismo de la violencia de género, en concreto la supuesta 
incidencia de la violencia de mujeres hacia hombres, como motivo para rechazar el uso de "violencia machista". Cabe mencionar no obstante que el grupo GH no polemizó sobre este aspecto, y los participantes hicieron suya la declaración de uno de los miembros que reivindicaba las expresiones "violencia machista" y "terrorismo machista" como las óptimas para este efecto.

Por su parte, los comentarios de los grupos femeninos a este respecto fueron los siguientes: las participantes en GM plantearon problemas al uso de "violencia de género" y "violencia machista", si bien por cuestiones de distinta índole que los grupos masculinos, al observar en su caso las participantes un cierto carácter eufemístico en estas expresiones. De este modo, reclamaron la utilización de expresiones más precisas y comprensibles para la ciudadanía, como "asesinato", en los casos que corresponda.

Continuando con el léxico empleado en las noticias, éste obtuvo severas críticas en la sesión del grupo CM, condenándose el uso de fórmulas pasivas como "morir por violencia de género" o "aparecer muerta" frente a opciones como "ser asesinada". Este grupo también desechó el tratamiento de "víctimas" para las mujeres que sufren violencia, y el uso de "violencia de género", por las mismas razones que el grupo GM. La presencia de una jurista en el grupo MM centró por su parte el foco en la falta de rigor de los tecnicismos jurídicos empleados por los profesionales de la información, que a su juicio alcanza a distorsionar la información en la noticia "Sentencias Condenatorias".

La legitimidad de las fuentes informativas fue una de las cuestiones cruciales tratadas en estas sesiones:

Los participantes de todos los grupos fueron preguntados por la inclusión del testimonio de una vecina de la mujer asesinada en la noticia "Caso Ciudad Jardín". Aun cuando este punto fue uno de los más controvertidos de todas las sesiones, sólo uno de los grupos, CM, desaprobó unánime y frontalmente esta fuente, considerada en su caso ilegítima por su falta de rigor y su pertenencia a un ámbito estrictamente privado. Los demás aprobaron parcialmente el recurso 
a esta fuente informativa o apreciaron en su caso valores positivos en ella. Así, a excepción del grupo MH, cuyos miembros no dudaron de la rigurosidad de este tipo de fuentes dada su cercanía a los hechos, el resto de grupos cuestionaron de un lado su fiabilidad, y legitimidad por los motivos anteriormente expuestos, al tiempo que apoyaron decididamente la participación de estas fuentes informativas como factores clave en la sensibilización de la población y el llamamiento a la colaboración ciudadana contra la violencia machista. Los grupos $\mathrm{CH}, \mathrm{GH}$ y MM también valoraron positivamente el carácter indirecto y anónimo de la participación de la vecina en la noticia.

El papel de los poderes públicos reunió a todos los participantes de los distintos grupos en un mismo diagnóstico, esto es, la desautorización de los representantes institucionales como fuentes informativas legítimas, en función de sus intervenciones en las tres noticias seleccionadas. Si algunos de los asistentes describieron como inevitable la presencia de las autoridades políticas en las noticias, en general todos los grupos coincidieron en: la inconsistencia y dudosa autenticidad de sus respectivos discursos, la incoherencia entre estos y sus acciones como representantes institucionales en lo concerniente al lanzamiento de políticas contra la violencia machista, y una motivación meramente interesada o propagandística de su presencia en los medios. Al hilo de esto, se demandó la participación de fuentes informativas alternativas, como expertos, académicos, activistas feministas y trabajadores sociales vinculados con la asistencia y el estudio de la violencia machista.

Como último punto referido a las fuentes de la información, todos los grupos elogiaron la participación del representante de la Asociación de Hombres por la Igualdad de Género (AHIGE) en la noticia "Sentencias Condenatorias". Se valoró positivamente la aparición de figuras masculinas no institucionales en las noticias sobre violencia machista, al considerarlas síntoma de un cambio social significativo y un modelo para el quebrantamiento de estereotipos y roles de género. Los participantes masculinos señalaron una mayor empatía e identificación ante la presencia de estas fuentes informativas. 
En otro orden, los 6 grupos fueron preguntados por su valoración de la alusión en las noticias a la eventual existencia de denuncias previas por maltrato en las parejas en cuestión. Tan sólo el grupo GM expresó su adhesión sin matices a la difusión de esta información, interpretada por las participantes desde una voluntad de concienciación de la ciudadanía en la denuncia de los actos de violencia. Este carácter didáctico fue apreciado por otros grupos como GH, MH y MM, aunque estos y los restantes advirtieron ciertos efectos negativos asociados a la mención a las denuncias previas, entre ellos el posible efecto disuasorio para las mujeres que padecen violencia, que a juicio de estos participantes pueden verse desalentadas al comprobar la ineficacia de las denuncias en los casos en que éstas no hayan prevenido el maltrato o asesinato. En la sesión del grupo CM, del que formaban parte dos mujeres con formación en género y experiencia en trabajo asistencial con mujeres que padecen violencia, se apuntaron otras causas que fundamentaban su rechazo frontal a la mención a cualquier denuncia previa, como la falta de correlación entre la interposición de una denuncia y la evitación de maltrato o un cierto desplazamiento de la responsabilidad hacia la mujer maltratada, al dar a entender que de ella depende el comienzo del proceso que pondría deseablemente fin a la violencia.

Los perfiles de las víctimas y los agresores representados en las noticias constituyen el último aspecto del tratamiento informativo analizado en las sesiones. La repetida mención a la nacionalidad de aquellos en la noticia "Caso Nijar" fue el dato que más atención acaparó y ante el que las reacciones fueron similares en todos los casos. Todos los grupos calificaron de excesiva la reiteración de este dato, así como lo innecesario del mismo. Más allá, expresaron su preocupación por que la mención a la nacionalidad contribuyese a consolidar estereotipos en torno a la violencia machista y su incidencia entre las minorías étnico-culturales, lo que podría afectar según se mencionó en varias ocasiones a la integración de estas minorías, fomentando su discriminación.

Otro dato de los perfiles destacado en las sesiones fue la profesión de la víctima y el agresor, juzgada como superflua por el grupo $\mathrm{CH}$. Las 
participantes del grupo CM reivindicaron por su parte una clara identificación de los agresores como "asesinos" en los casos en que corresponda, y una disociación del perfil de víctimas de las mujeres que padecen violencia. Por último, cabe destacar en este apartado la valoración positiva que del anonimato de ambos perfiles se hizo en la sesión del grupo MM.

\section{Percepciones sobre violencia machista}

El visionado de las noticias seleccionadas hizo aflorar de manera espontánea ciertas consideraciones generales y creencias que los participantes de los distintos grupos ostentan acerca de la violencia machista. A pesar de que estas reflexiones y comentarios excedían nuestra inicial propuesta a los grupos, esto es, el análisis colectivo de determinados patrones y elementos de la información, merecen una atención especial por dos motivos: por un lado desvelan la capacidad de los mensajes audiovisuales para revelar preconceptos sobre la violencia machista; por otra parte, nos aportan claves para la comprensión de la interacción entre esas ideas y creencias sobre la violencia de género instaladas en la sociedad y la recepción de los mensajes audiovisuales sobre el tema.

Comenzando por la situación jurídico-legislativa de la violencia de género, todos los grupos coincidieron en su valoración, y en todas las sesiones los participantes se mostraron unánimes en su juicio. La principal convicción compartida en este sentido fue la falta de voluntad política ante el problema, traducida en una ausencia de recursos destinados al efecto, y la consecuente ineficacia política y judicial en la prevención y erradicación de la violencia, instancias aquellas, las fuerzas de seguridad y la justicia, ante las que los participantes expresaron una firme desconfianza. En línea con esto, los gestos públicos de condena de la violencia protagonizados por las autoridades públicas y recogidos en las noticias seleccionadas fueron duramente cuestionados en un contexto de recortes en políticas sociales ejecutados por los mismos representantes políticos protagonistas de estos gestos de repulsa. 
Otro de los aspectos en los que observamos una práctica coincidencia en todos los grupos es la valoración de la dimensión pública de la violencia de género. El testimonio de una vecina de la mujer asesinada en "Caso Ciudad Jardín" suscitó el debate sobre la colaboración ciudadana con las fuerzas de seguridad en la detección de la violencia machista. Si bien los participantes en estas sesiones asumían y reivindicaban el compromiso y la obligación moral de toda la ciudadanía en la denuncia de este tipo de violencia, en cada sesión fueron descritos diversos obstáculos que dificultarían en gran medida el ejercicio de esta responsabilidad. Entre las razones aducidas: el miedo ante la falta de garantías de protección de los testigos, lo arduo de un proceso que los participantes prefiguran desalentador, el creciente individualismo de la sociedad, y causas socio-culturales que continúan circunscribiendo el fenómeno de la violencia al ámbito privado.

En cuanto a los fundamentos de la violencia machista, todos los grupos apuntaron para explicar la pervivencia de este fenómeno motivos culturales, históricos y religiosos tales como la quiebra del patriarcado y el rechazo de ciertos sectores masculinos a la emancipación de la mujer, o el machismo instalado en nuestra sociedad como resultado de cuatro décadas de dictadura franquista, con su correspondiente e impuesta moral religiosa y privada. Sólo uno de los grupos, GM, estableció una correlación entre la situación socio-laboral y el incremento de la violencia machista, en el actual contexto de crisis económica.

En este punto cabe destacar también un sesgo de género. Además de los factores culturales, los tres grupos femeninos incidieron en la educación como pilar esencial en el mantenimiento de patrones machistas, y por ende de la violencia contra las mujeres. En este sentido, GM, CM y MM mostraron su preocupación por la incidencia de la violencia en la población más joven, censurando ideales como el del "amor romántico", consolidado en la adolescencia, y reivindicando una educación igualitaria como la fórmula para la desaparición de estas prácticas. 
En tres de las sesiones se mencionó la presunta existencia de un índice significativo de denuncias falsas por maltrato en la pareja. Si en el grupo GM la convicción sobre esta existencia parecía compartida por las participantes, en el caso del grupo $\mathrm{MH}$ el tema generó claras tensiones entre algunos de sus miembros, divididos entre quienes esgrimían la crisis económica y una supuesta sobreprotección legislativa de la mujer como explicación al fenómeno y quienes minimizaban la relevancia de unos casos aislados. Los mismos motivos se enarbolaron en la sesión MM, aunque una de las participantes, jurista de formación, acabó matizando la supuesta falsedad de las denuncias presentadas.

Es destacable que en los tres grupos en que se aludió a las denuncias falsas también se mostró cierto desacuerdo con una noción de la violencia de género referida estrictamente a aquélla ejercida por hombres hacia mujeres en el seno de la pareja. Fueron varios los miembros de estos grupos que constataron la existencia de un tipo frecuente de violencia de mujeres hacia hombres, si bien obviada por los medios y por la sociedad según estas opiniones, y reivindicaron el uso de la expresión "violencia de género" para hacer referencia a la misma, comentarios que generaron polémica en algunos casos.

Por último, subrayar que los tres grupos femeninos prestaron una especial atención al complejo proceso que deben enfrentar las mujeres que padecen violencia. Las participantes compartieron sus percepciones acerca de un camino plagado de obstáculos y presiones en el que las mujeres no cuentan con la comprensión de la sociedad ni de las instituciones. Así, en las sesiones de GM, MM y CM principalmente, las participantes atendieron a la indefensión jurídica de las mujeres en esta situación, con mención especial a las inmigrantes, y se mostraron sensibles ante los aspectos psicológicos y afectivos, tales como la existencia de hijos o la falta de autoestima, que complican a las mujeres el camino de salida de la violencia.

\section{Medios de comunicación y violencia de género}

En 4 de los 6 grupos de discusión el visionado de las distintas noticias dio pie a sus miembros a exponer sus opiniones acerca de los medios 
de comunicación, la televisión en concreto, su funcionamiento y dinámicas y cómo éstas influyen en el tratamiento de la violencia machista en las pantallas. Los participantes también se manifestaron acerca de la influencia y responsabilidad de los medios en la creación de una conciencia ciudadana en torno a este tipo de violencia.

La valoración del impacto de los medios de comunicación en la concienciación ciudadana sobre el tema fue el aspecto más discutido en todas las sesiones. En las de los grupos GM, $\mathrm{CH}$ y $\mathrm{MH}$ se reconoció el deber ineludible de los medios para con la ciudadanía en la información de una cuestión de esta envergadura, y se reivindicó su indispensable papel en la sensibilización y visualización de la violencia machista en todas sus dimensiones. Para el grupo $\mathrm{CH}$ la tarea va más allá de la divulgativa y la educativa, y el compromiso de los medios ha de pasar por la denuncia pública de estos actos. Si esta función también le fue reconocida durante la sesión del grupo $\mathrm{MH}$, el impacto de los medios en este sentido fue relativizado frente a otros entornos más cercanos, como el familiar o el educativo, así como respecto a la propia naturaleza del medio televisivo, en el que la habitual presencia de contenidos de violencia minimiza, según algunas opiniones vertidas, un eventual efecto de concienciación atribuido a las noticias informativas.

Las percepciones acerca de la presencia de contenidos sobre violencia machista en los medios audiovisuales fueron dispares en cada grupo. Para el grupo CM ésta es más excesiva que suficiente y puede explicarse desde una tendencia mediática pasajera con eventuales consecuencias negativas para la ciudadanía, como la posible imitación por parte de los maltratadores de las prácticas violentas descritas en las noticias o una progresiva insensibilización social hacia el problema. Para el grupo $\mathrm{MH}$ por su parte, estos contenidos no resultan de interés para las cadenas televisivas, al no competir en términos de audiencia con otros. El debate se centró no obstante en los aspectos cualitativos de esa presencia en las programaciones televisivas, así como en el posicionamiento de los mismos en las parrillas, aspecto a privilegiar a su juicio. 
Por último, destacaremos un aspecto ampliamente discutido por los grupos GM y MM y relacionado con las dinámicas de producción y las particularidades del medio televisivo. Como destacaron algunos de sus miembros, los detalles sobre los actos violentos facilitados en las noticias, y que calificaron como morbosos, responden a una necesidad de "rellenar" los contenidos televisivos, de acuerdo con las exigencias propias del medio. Así mismo, también expresaron preocupación por la precariedad laboral en los medios de comunicación, y cómo ésta pudiera afectar a la calidad de las informaciones emitidas.

\section{Recomendaciones}

Recopilamos a continuación las recomendaciones, tanto generales como específicas, que para la mejora del tratamiento informativo de la violencia machista en televisión se consensuaron al término de cada sesión de los grupos de discusión:

-Fomentar la elaboración de noticias orientadas a la sensibilización de la población y que expliquen la violencia machista como un problema estructural, con formatos como debates y documentales.

-Aportar siempre la interpretación de los datos estadísticos.

-Sustituir habituales fuentes informativas, por ejemplo miembros del vecindario, por expertos como asociaciones, académicos y servicios sociales, con el objeto de promover contenidos divulgativos y ampliar la perspectiva de la violencia machista, trascendiendo cualquier carácter doméstico o privado.

-Rebajar en la medida de lo posible de la participación de políticos como fuentes de la información.

-Favorecer un análisis crítico de las políticas sobre violencia machista. Contar con aquellos colectivos, feministas y asociaciones de mujeres maltratadas de manera destacada, más críticos con las políticas institucionales.

-Propiciar en general una mayor presencia de mujeres en las noticias. 
-Dotar a las noticias de un enfoque positivo orientado a la transmisión de apoyo a las mujeres que padecen violencia. Destacar, como ejemplo, los datos de sentencias condenatorias frente a las absolutorias.

-Mencionar las condenas aplicadas a los asesinos y agresores como medida disuasoria. Incluir fotografías o imágenes del rostro de los maltratadores condenados.

-Evitar todos y cada uno de los detalles del asesinato o agresión en el relato de los hechos.

-Eliminar cualquier imagen de cadáveres (aun cubiertos y sin identificar).

-No abusar de las imágenes de los escenarios de los asesinatos, con objeto de eliminar estereotipos acerca de la incidencia de la violencia en determinados entornos socioeconómicos.

-Prescindir de los datos personales de víctimas y agresores, en concreto la profesión y la nacionalidad de ambos, en la redacción de la noticia.

-No abusar del lenguaje técnicos o los eufemismos.

-Revisar el rigor en el uso de léxico técnico.

-Caracterizar claramente como asesinatos los casos de violencia resultantes en muerte.

-Excluir el término "víctima" para referirse a las mujeres que padecen violencia o han sido asesinadas.

- Incluir en los informativos contenidos de condena hacia las actitudes machistas de personajes públicos como formas de violencia machista.

-Ofrecer modelos positivos de mujeres que hayan superado la violencia machista, a saber, mujeres empoderadas y "triunfadoras".

\section{A modo de conclusiones}

El calado de las reflexiones surgidas en las sesiones de los grupos de discusión actúa como un recordatorio de la perentoria necesidad de 
consolidación de una audiencia, y por extensión una ciudadanía, crítica con los discursos mediáticos, audiovisuales en este caso. Trasladada esta idea de manera específica a la cuestión de la violencia machista, las ciudadanas y ciudadanos reunidos por el Observatorio enfrentan estos mensajes y el debate en torno a ellos desde una clara asunción: el carácter público, y por tanto de interés social prioritario, de un fenómeno del que ya no cabe contemplar dimensión privada ni doméstica alguna, el cual por tanto apela directamente a nuestra condición, sea ésta de espectadores, ciudadanos, productores de informaciones y/ o representantes de los poderes públicos.

Son muchas las conclusiones que se desprenden de lo debatido en los grupos, como diversas las dimensiones que engloban. Si bien resulta evidente que los participantes confirman que continúan siendo muchos los aspectos éticos o formales dignos de revisión en su tratamiento informativo, los resultados de la aplicación de esta dinámica también reflejan lo controvertido de una cuestión como la violencia machista, tanto en su comprensión y valoración social como en la ejecución de medidas políticas, mediáticas incluidas, dirigidas a su progresiva desaparición. Valgan como ejemplo las reiteradas y duras críticas hacia los representantes públicos y la eficacia de su gestión, pero también los síntomas de confusión o desinformación que sobre la idea misma de "violencia machista" se dejaron entrever en las sesiones.

Con todo, lo cierto es que más allá de la función meramente informativa, la ciudadanía parece reclamar a los medios un compromiso con la producción de contenidos de corte divulgativo, orientados a promover la concienciación ante la violencia de género y a contribuir a la consecución de una sociedad igualitaria, desde las bases de la educación. Se trata, sin ir más lejos, de una demanda a los medios de su cumplimiento como servicio público, una exigencia si cabe aún más imperiosa tratándose, como ha sido el objeto de nuestro estudio, de un canal público como la televisión autonómica andaluza.

Conscientes como apuntábamos de la naturaleza compleja de las violencias hacia la mujer, las ciudadanas y ciudadanos convocados por 
el Observatorio reivindicaron la utilidad social de estas informaciones, $\mathrm{y}$ es de esta aspiración de donde parte el rechazo a cualquier tratamiento informativo instrumentalizado políticamente. Con la misma voluntad, emplazaron a los productores de la información a ampliar la consideración de la violencia machista para, además de los feminicidios o las agresiones físicas, identificar los múltiples grados y manifestaciones de la violencia, como primer paso para la producción de un discurso responsable y el diseño de una programación televisiva coherente.

Los grupos de discusión revelaron pues qué aspectos de la comunicación, qué recursos utilizados por los medios en estas informaciones, están siendo en su opinión consecuentes con la lucha contra la violencia machista y el propósito último de la construcción colectiva de una sociedad igualitaria. Nos aportaron pistas de la eficacia de estos mensajes y nos alertaron del posible efecto de alejamiento de esa vocación divulgativa que las condiciones de producción de la información, su esquematismo y limitaciones, así como una posible instrumentalización política de la misma, podrían tener. A través de una herramienta cualitativa como los grupos de discusión se manifestaba así el deber de continua reevaluación de los medios, y la necesidad de un diálogo entre estos, las instituciones y la sociedad civil.

\section{Referencias bibliográficas}

GIL FLORES, J. "La metodología de investigación mediante grupos de discusión” en Enseñanza \& Teaching: Revista interuniversitaria de didáctica, no10-11, 1992-1993, pp. 199-214.

GUTIÉRREZ BRITO, J. Dinámica del grupo de discusión. Centro de Investigaciones Sociológicas, Madrid, 2008.

KRUEGER, R. A. El grupo de discusión: guía práctica para la investigación aplicada. Pirámide, Madrid, 1991. 


\title{
El papel garantista del Consejo Audiovisual de Andalucía del tratamiento informativo ético de la violencia machista en los medios
}

\author{
Ana Jorge Alonso \\ Universidad de Málaga \\ Código Orcid ${ }^{23}$
}

$\mathrm{E}$ L gran reto del siglo XXI es la construcción de sociedades sólidamente asentadas sobre los principios de derechos fundamentales ${ }^{24}$ que aseguren el pleno bienestar de la población,

${ }^{23}$ http:// orcid.org/0000-0003-2597-6491

${ }^{24}$ Referente al concepto de derechos humanos, se pueden tomar como sinónimos otras expresiones como derechos fundamentales, derechos del hombre o derechos del ciudadano. No obstante, si tenemos en cuenta las palabras del profesor Gregorio Peces-Barba, todos esos términos "tienen connotaciones culturales y explicaciones derivadas de un contexto bistórico, de unos intereses, de unas ideologias y de unas posiciones cientificas o filosóficas de fondo". Por eso, aunque el término derechos humanos sea más común y utilizado tanto en el plano jurídico como en el político, no es el más idóneo. Peces-Barba propone el término derechos fundamentales, ya que "puede comprender tanto los presupuestos éticos como los componentes jurídicos, significando la relevancia moral de una idea que compromete la dignidad bumana y sus objetivos de autonomía moral, y también la relevancia jurídica que convierte a los derechos en norma básica material del Ordenamiento, y es instrumento 
siendo imprescindible para ello la vigencia de los derechos humanos, entre los que se encuentra la igualdad entre hombres y mujeres, entendiendo que la violencia de género es la máxima expresión de su ausencia.

Por lo que se refiere al papel de los medios de comunicación, tanto las legislaciones nacionales como las internacionales, legitiman el principio según el cual estos juegan un papel decisivo en la conformación de una cultura de derecho y de igualdad. Y, más concretamente, en la aplicación efectiva de estas disposiciones las autoridades de regulación tienen también una responsabilidad, ya que se ven interpeladas en cuanto a la igualdad de género por las obligaciones surgidas de la garantía de la libertad de expresión y de los principios generales relativos al respeto hacia la dignidad humana y de lucha contra todas las formas de discriminación o violencia.

La confrontación entre la ideología dominante, sin lugar a dudas de carácter patriarcal, con una ideología de matriz subversiva como el feminismo, produce profundos desajustes. La lucha colectiva e individual, y los consecuentes cambios de roles se traducen en tensiones en las relaciones interpersonales, constituidas como relaciones de poder. El cuestionamiento del poder de los varones desata los mecanismos del ejercicio de la violencia, como forma la recuperación del control, en sus distintas formas desde la más sutil como la psicológica, que a menudo es ignorada por el discurso público en general, especialmente el mediático, porque como Cynthia Carter advierte no cumplen con los criterios noticiosos, y son percibidos por como algo de lo que no hay que preocuparse (CARTER Cynthia. y STEINER Linda: 2004, p.230) ${ }^{25}$, incluso hasta

necesario para que el individuo desarrolle en la sociedad todas sus potencialidades. Los derechos fundamentales expresan tanto una moralidad básica como una juridicidad básica". (Vid., PECES-BARBA MARTÍNEZ, Gregorio, et. al. Curso de Derechos Fundamentales. Teoría General. Madrid: Universidad Carlos III, 1999. p. 21-38).

${ }^{25}$ CARTER Cynthia. y STEINER Linda, (eds). Critical readings. Media and gender. Londres, Open University Press, 2004, p. 230. 
la eliminación física de las mujeres por parte de sus parejas o exparejas.

En esta línea de reconstrucción de las identidades y por tanto de las relaciones de género se inserta esta aportación. Para ello se parte de la conciencia de lo que ha significado el movimiento feminista en su conjunto a lo largo de la historia pero también de las aportaciones desde diversas posiciones feministas en el ámbito académico. Los efectos de estas representaciones, sobre todo en los últimos tiempos en los medios de comunicación, tanto del género como de las relaciones amorosas influyen no solo en la conformación del discurso público en torno al gran problema de la violencia hacia las mujeres. En muchos casos, también tendrían consecuencias directas en el comportamiento de las mujeres, afectando en gran medida a su libertad.

Quizá sea el momento de aceptar el carácter contingente de ese futuro de progreso sin fin que habíamos imaginado. Pensar que las cotas de libertad e igualdad conseguidas son debidas a la lucha de los colectivos oprimidos y no la consecuencia de una especie de superioridad cultural que nos caracteriza. Por esa razón la evaluación de las políticas públicas y las subsiguientes propuestas de mejora son uno de los cometidos que desde el ámbito académico debemos abordar. Para ello se analizará, en primer lugar, el marco legal y las funciones del Consejo Audiovisual Andaluz y, en segundo lugar, las actuaciones que el mismo ha llevado a cabo en materia de violencia de género en cuanto a su tratamiento informativo en los medios.

\section{El Consejo Audiovisual Andaluz: marco legal y competencial}

Al hacer el análisis del Consejo Audiovisual Andaluz y donde se enmarca su legitimidad a la hora de garantizar un tratamiento informativo ético de la violencia de género, se hace imprescindible explicitar el marco legal que pone en relación la igualdad de género y los medios de comunicación, en primer lugar, para después analizar las funciones del CAA en la materia. 


\subsection{E1 marco legal}

Los derechos fundamentales se han establecido de manera formal, en mayor o menor grado, como veremos más adelante, en numerosos textos jurídicos, para luchar contra la opresión, contra todas las formas de opresión. Para Hannah Arendt, los derechos humanos no están previamente establecidos, ya que constituyen una invención humana, en constante proceso de construcción y reconstrucción (AREDNT, Hannah: 1987. p. 422-438). ${ }^{26} \mathrm{Si}$ se tiene en cuenta la historicidad de estos derechos, se puede afirmar que la definición de derechos humanos apunta hacia una pluralidad de significados. Al considerar dicha pluralidad, este estudio destaca la llamada concepción contemporánea de los derechos humanos, que se introduce con el advenimiento de la Declaración Universal de 1948 y se reitera en la Declaración de Derechos Humanos de Viena de 1993.

Esta concepción es el resultado del movimiento de internacionalización de los derechos humanos, que constituye un movimiento muy reciente en la historia y que surge, a partir de la post segunda guerra mundial, como respuesta a las atrocidades y a los horrores cometidos durante el nazismo. Es ese el panorama en el que se articula el esfuerzo de reconstrucción de los derechos humanos como paradigma y referente ético que orienta el orden internacional contemporáneo.

Así mismo, es necesario aclarar que en todos los textos que hacen referencia a los derechos fundamentales se establece tanto la vertiente subjetiva del derecho a la no discriminación, es decir, en sí misma, como la objetiva de que las autoridades deben promover dicho derecho.

La relación entre la igualdad de género y los medios audiovisuales tiene su fundamento en los principios fundamentales de los derechos humanos, tanto la libertad de expresión como el derecho a obtener y recibir información veraz y cierta, con respeto a la dignidad humana

${ }^{26}$ AEDNT, Hannah. Los orígenes del totalitarismo, 2. Imperialismo. Madrid: Alianza Editorial, 1987. p. 422-438. 
en sociedades democráticas, así como a la no discriminación por razón de sexo.

Así, proteger los derechos de las mujeres en y a través de los medios y su contenido, ha motivado desde hace años que en la esfera internacional se genere una amplia gama de acuerdos y de recomendaciones.

Al lado del sistema normativo global, surgen los sistemas regionales de protección que procuran internacionalizar los derechos humanos. El sistema global y el regional no son dicotómicos, sino complementarios. Al adoptar el valor de la primacía de la persona humana, estos sistemas se complementan e interactúan con los distintos sistemas de protección regionales: Europa, España y Andalucía en el caso que nos ocupa, con el objetivo de que haya una mayor efectividad en la tutela y en la promoción de los derechos fundamentales. Por otro lado, es necesario reseñar que la concepción contemporánea de los derechos humanos está caracterizada por los procesos de universalización e internacionalización de los mismos, entendidos desde el prisma de su indivisibilidad. ${ }^{27}$

Los textos jurídicos europeos que protegen la igualdad de género son: El Convenio para la salvaguarda de los Derechos Humanos y Libertades Fundamentales $^{28}$, La Carta Social Europea ${ }^{29}$ (que puede

${ }^{27}$ La Convención sobre la Eliminación de todas las Formas de Discriminación Racial, la Convención sobre la Eliminación de la Discriminación contra la Mujer y la Convención sobre los Derechos del Niño contemplan no solamente los derechos civiles y políticos, sino también los derechos sociales, económicos y culturales, lo que apoya la idea de la indivisibilidad de los derechos humanos.

${ }^{28}$ CONSEJO DE EUROPA. El Convenio Europeo para la Protección de los Derechos Humanos y de las Libertades Fundamentales, más conocido como la Convención Europea de Derechos Humanos, fue adoptado por el Consejo de Europa el 4 de noviembre de 1950 y entró en vigor en 1953. Se inspira expresamente en la Declaración Universal de Derechos Humanos, proclamada por la Asamblea General de las Naciones Unidas el 10 de diciembre de 1948. que tiene por objeto proteger los derechos humanos y las libertades fundamentales de las personas sometidas a la jurisdicción de los Estados miembros, y permite un control judicial del respeto de dichos derechos 
catalogarse como el Pacto Europeo por la Igualdad (JIMENA QUESADA, Luis y TOMÁS MALLÉN, Beatriz: 2007, p. 339-359) $)^{30}$ y que ha tenido que adaptarse a las recientes necesidades de lucha contra las desigualdades emergentes y a las nuevas exigencias de inclusión social ${ }^{31}$ ), la Declaración sobre los Derechos Humanos ${ }^{32}$, la Carta de los derechos fundamentales de la Unión Europea ${ }^{33}$, la Carta

individuales, establece, en su artículo 14, que el disfrute de los derechos reconocidos en el texto estar asegurado sin distinción alguna por razón de sexo.

${ }^{29}$ Firmada en Turín el 18 de octubre de 1961. Ratificada por España por Instrumento de 29 de abril de 1961. Con motivo de su veinticinco aniversario, el Consejo de Ministros del Consejo de Europa adoptó un protocolo adicional, de 5 de mayo de 1988, ratificado por España el 7 de enero de 2000. Tiene como objetivo mejorar el nivel de vida, establece en su Preámbulo el principio de no discriminación como pauta para la satisfacción de los derechos sociales, lo que proyecta la igualdad de manera transversal sobre el conjunto de disposiciones. ${ }^{30}$ JIMENA QUESADA, Luis y TOMÁS MALLÉN, Beatriz. "Hacia un estándar europeo común de igualdad: la contribución del comité europeo de derechos sociales". Revista de Derecho Político. 2007, No 68, p. 339-359.

${ }^{31}$ Esa adaptación se ha producido mediante el Protocolo de 1988, el Protocolo de 1995 y, sobre todo, la Carta Social Europea revisada de 1996. En especial, en la nueva Carta Social de 1996 se introduce una cláusula específica reconociendo ampliamente el principio de igualdad y se consagran nuevos derechos.

${ }^{32}$ Adoptada por el Comité de Ministros el 27 de abril de 1978 durante su sesión 62.

${ }^{33}$ Firmada en Niza el 7 de diciembre de 2000. recoge en un único texto, por primera vez en su historia, el conjunto de los derechos civiles, políticos, económicos y sociales de la ciudadanía europea y de todas las personas que viven en el territorio de la Unión. Estos derechos se agrupan en seis grandes capítulos, entre los que se encuentra la igualdad. 
de la Mujer ${ }^{34}$, el Pacto por la igualdad de género $2011-2020^{35}$ y la Estrategia Europa $2020^{36}$.

Respecto a los instrumentos específicos en materia de igualdad de género y del papel de los medios de comunicación, existen por parte de la Asamblea parlamentaria del Consejo de Europa:

1.- La Resolución $1557^{37}$ (2007) y la Recomendación 1799 (2007) «Imagen de la mujer en la publicidad» ${ }^{38}$

2.- La Recomendación 1555 (2002) $)^{39}$ «Imagen de la mujer en los medias» (2007);

3.- La Resolución 1751 (2010) del Consejo de Europa "Luchar contra los estereotipos sexistas en los medias". En dicho texto se explicita que: "La representación de los estereotipos sexistas que van desde el humor y los clichés en los medias tradicionales, hasta la incitación al odio y a la violencia basada en el sexo en internet. Los estereotipos sexistas, están demasiado banalizados y tolerados, en nombre de la libertad de expresión. Además, estos estereotipos sutilmente vinculados a los media, que reproducen las actitudes y las opiniones percibidas como la norma por la sociedad, donde la igualdad de género está muy lejos de ser una realidad. De hecho,

${ }^{34}$ https://www.msssi.gob.es/ssi/igualdadOportunidades/internacional/unioneu ropea/CartadelasMujeres.pdf

${ }^{35}$ http:/ / eur-

lex.europa.eu/LexUriServ/LexUriServ.do?uri=OJ:C:2011:155:0010:0013:ES:P

DF

${ }^{36}$ http:/ / ec.europa.eu/archives/commission_2010-

2014/president/news/documents/pdf/20100303_1_es.pdf

${ }^{37}$ http://assembly.coe.int/Mainf.asp?link=/Documents/AdoptedText/ta07/F RES1557.htm

${ }^{38}$ https://wcd.coe.int/ViewDoc.jsp?id=1252927\&Site $=\mathrm{CM}$

${ }^{39}$ https: / / wcd.coe.int/ViewDoc.jsp?id=16807\&Site $=\mathrm{CM}$

${ }^{40}$ https://wcd.coe.int/ViewDoc.jsp?id=1770223\&Site=CM 20 
muchas veces, los estereotipos sexistas no pueden ser atacados judicialmente o sancionados por las instancias de regulación y de autorregulación, excepto los casos muy graves de violación de la dignidad humana".

El Comité de los Ministros del Consejo de Europa tiene las siguientes:

1.- Las Recomendaciones referidas a la igualdad de género en los medias : Las del 25 de septiembre de $1984 \operatorname{Rec}(84) 1734^{41}$, y la reciente CM/Rec (2013)1 del 10 de julio de 2013 sobre "La igualdad de género y los medias" y que están acompañadas por "Líneas directrices" que se dirigen tanto a los "Estados miembros", como a los "Organismos de medias", contando también con los reguladores, y que llama a la toma de "Medidas de aplicación", tales como:

- Examen y evaluación de las leyes y las políticas en materia de igualdad de género

- Adopción y aplicación de indicadores nacionales de la igualdad de género en los medias

- Suministro de información y promoción de buenas prácticas

- Mecanismos de responsabilidad

- Investigación y publicación

- Educación para los medias y la ciudadanía activa.

2.- La Recomendación CM/Rec (2007)17 sobre las "normas y mecanismos de igualdad de género" ( 2007). ${ }^{42}$

3.- Las recomendaciones del Consejo, de orden más general, especialmente aquellas relativas a:

- El enfoque ofrecido a la igualdad de género CM/Rec (98)14), e igualdad de género en la educación CM/Rec (2007)13, así como

\footnotetext{
${ }^{41}$ http://www.coe.int/t/dghl/standardsetting/media/doc/CM/Rec(1984)017_f r.asp\#TopOfPage

${ }^{42}$ http://www.euromed-justice.eu/fr/node/454
} 
a las que se refieren a la participación equilibrada de las mujeres y de los hombres en la toma de decisión política y pública relativo a CM/Rec (2003)3.

- la promoción de la diversidad de los contenidos y de la pluralidad de los medias: las recomendaciones de enero de 1999, $n^{\circ} \mathrm{R}$ (99)1 $1^{43}$, y la del 31 de enero de 2017, CM/Rec (2007) $2^{44}$.

- Otras que conciernen a la libertad de expresión, a la cultura de los derechos humanos y de la democracia, así como a la lucha contra la violencia en los medias tales como : Las recomendaciones 1466 sobre la protección del papel de los medias en las democracias en el contexto de la concentración de los medias, del 31 de enero de 2007, sobre la educación de los medias", de 2007 sobre "los medias y la promoción de una cultura de tolerancia", "la misión de los medias de servicio público en la sociedad de información" (y "la gobernanza de los medias de servicio público" (2012) como las recomendaciones CM/Rec (2007)11 sobre la promoción de la libertad de expresión y de información en el nuevo ambiente de información y de la comunicación del 30 de octubre de 1997 sobre la representación de la violencia en los medios electrónicos y Rec (90)4 sobre la eliminación del sexismo en el lenguaje.

Aterrizando en el marco legal nacional, la Constitución Española de 1978, en su artículo 10, garantiza que las normas relativas a los derechos fundamentales y a las libertades reconocidas en la misma se interpretarán de conformidad con la Declaración Universal de Derechos Humanos y los Tratados y acuerdos internacionales sobre las mismas materias ratificadas por España. Y en su artículo 14, establece el principio de igualdad ante la Ley, sin que pueda prevalecer discriminación alguna por razón de nacimiento, raza, sexo, religión, opinión o cualquiera otra condición o circunstancia personal o social. Es decir, que a la declaración de igualdad se suma la

\footnotetext{
${ }^{43} \mathrm{https}: / /$ wcd.coe.int $/$ ViewDoc.jsp?id $=399231 \&$ Site $=\mathrm{CM}$

${ }^{44}$ https: / $/$ wcd.coe.int/ViewDoc.jsp?id $=1089651 \&$ Site $=$ CM
} 
prohibición de discriminación que supone una ampliación de facto del derecho hacia otras parcelas de las relaciones sociales, esto es, hacia las discriminaciones directas y también las indirectas $\mathrm{O}$ encubiertas por una situación formal de igualdad (SAEZ LARA, Carmen: 1994).$^{45}$ Por su parte, el artículo 1.1 de la Constitución señala la igualdad como valor superior del ordenamiento jurídico, lo que los juristas consideran como una igualdad sustancial sumada a la formal del artículo 14. Así mismo, incorpora en su artículo 15 el derecho de todos a la vida y a la integridad física y moral.

Por su parte, la libertad de información a través de la televisión parece estar consagrada por el artículo 20 que regula la libertad de información y expresión y por tanto el derecho a emitir y recibir mensajes por cualquier medio. Incluso se hace referencia expresa a la regulación de los medios de comunicación en el apartado 3 del citado artículo 2046. Las libertades y derechos que se recogen en Sección Primera del Capítulo Segundo de Título Primero de la Constitución aparecen protegidos en su desarrollo por la reserva de Ley Orgánica y son, pues, tutelados a través del control de constitucionalidad de las leyes 47 . Se hace interesante reseñar que una vez agotadas las instancias españolas para la protección de estos derechos y libertades, se puede acudir a los órganos jurisdiccionales establecidos por el Convenio Europeo de Derechos Humanos.

La Carta Magna en su artículo 9.2, encomienda a los poderes públicos que promuevan las condiciones y remuevan los obstáculos para que

${ }^{45}$ SAEZ LARA, Carmen. Mujeres y mercado de trabajo: las discriminaciones directas e indirectas. Bruselas: Consejo económico y social, 1994.

46 "La ley regulará la organización y el control parlamentario de los medios de comunicación social dependientes del Estado o de cualquier Ente público y garantizará el acceso a dichos medios de los grupos sociales y políticos significativos, respetando el pluralismo de la sociedad y las distintas lenguas del estado."

47 Véase los artículos 81.1 y 53.1 de la Constitución Española. 
este derecho sea disfrutado en condiciones de igualdad por todos los ciudadanos. Sin embargo, este principio es menos preciso que los derechos anteriores, ya que existe una ausencia de contenido objetivo. La doctrina constitucional ha sido la encargada de dar esa objetividad $y$, en el caso de la igualdad, ha permitido ampliar la tutela constitucional admitiendo la legalidad de la discriminación positiva.

Por otro lado, establece en el artículo 149 que el estado tiene competencia exclusiva sobre las siguientes materias sobre el régimen general de comunicaciones, telecomunicaciones, radiocomunicación, las normas básicas del régimen de prensa, radio y televisión y, en general, de todos los medios de comunicación social, sin perjuicio de las facultades que en su desarrollo y ejecución correspondan a las Comunidades Autónomas".

Como telespectadores y telespectadoras los españoles son titulares del derecho a recibir información (González Encinar, J.J. y Salvador Martínez, M.: 2000)48 (arts. 20.1 a y d CE), del derecho a la cultura (art $44 \mathrm{CE}$ ) y a la educación (art. $27 \mathrm{CE}$ ). Asimismo, como objetos de la comunicación los ciudadanos se encuentran protegidos en su dignidad, honor, intimidad y propia imagen (arts. 10 y $18 \mathrm{CE}$ ). También es importante reseñar que el mandato constitucional que contiene el art. 20.3, según el cual la ley garantizará el acceso a los medios de comunicación social dependientes del estado o de cualquier ente público de los grupos sociales y políticos más significativos se ha reducido a la presencia de los partidos políticos con representación parlamentaria en los espacios gratuitos electorales.

Dos leyes orgánicas enmarcan de forma fundamental el trabajo que se está presentando: la Leyes Orgánicas 3/2007 para la igualdad efectiva de mujeres y hombres y la $1 / 2004$ de medidas de protección integral contra la violencia de género.

48 Sobre esta cuestión José J. González Encinar y María Salvador Martínez "La mujer y los derechos de la comunicación” pp. 669-691 en Enrique Álvarez Conde et al. Mujer y Constitución en España. Centro de Estudios Políticos y Constitucionales, Madrid, 2000. 
Al hilo del mandato constitucional (Art. 14 CE), en 2007 se aprueba la Ley Orgánica 3/2007, de 22 de marzo, para la igualdad efectiva de mujeres y Hombres ${ }^{49}$ (en adelante LOI), que trata de combatir todos los casos de discriminación, directa o indirecta, por razón de sexo y promover la igualdad real entre mujeres y hombres. Por lo tanto, nace, además de por otras razones de orden político, de la necesidad de unificar y desarrollar en un único texto con rango de ley orgánica, toda la normativa nacional y supranacional acerca del tema de la igualdad entre mujeres y hombres. De este modo, la Ley nace con la vocación de erigirse en ley-código de la igualdad entre mujeres y hombres, y para ello incorpora el principio de transversalidad y modifica múltiples leyes.

Con respecto a los medios de comunicación, esta ley le dedica un Título completo. A pesar de ello, como se explicará más adelante, la falta de concreción ha conducido a una imposibilidad de facto de protección efectiva de los derechos de las mujeres, dada la dificultad de ejercer la potestad sancionadora por parte de las autoridades administrativas y judiciales competentes, como es el caso que nos ocupa del Consejo Audiovisual Andaluz.

La Ley 1/2004 de medidas de protección integral contra la violencia de género adolece de la misma falta de concreción expuesta anteriormente en el caso de la ley 3/2007.

Por su parte, la Ley General de la Comunicación Audiovisual se presenta como norma básica no sólo para el sector privado sino también para el público fijando, con el más absoluto respeto competencial que marca nuestra Constitución, los principios mínimos que deben inspirar la presencia en el sector audiovisual de organismos públicos prestadores del servicio público de radio, televisión y servicios interactivos. En este sentido, la norma aspira a promover una sociedad más incluyente y equitativa y, específicamente en lo referente a la prevención y eliminación de discriminaciones de género,

${ }^{49}$ España. Ley Orgánica 3/2007, de 22 de marzo, para la igualdad efectiva de mujeres y Hombres. Boletín Oficial del Estado, 23 de marzo de 2007, No 71, p. 12611- 12645. 
en el marco de lo establecido en materia de publicidad y medios de comunicación en la Ley Orgánica 1/2004, de 28 de diciembre, de Medidas de protección integral contra la violencia de género y la Ley Orgánica 3/2007, de 22 de marzo, para la igualdad efectiva de hombres y mujeres.

En esta ley se encuentran las mismas carencias referenciadas en las anteriores leyes. Como elemento de contraste, esta ley sí que concreta exclusivamente en referencia a los menores, al margen de la remisión a la ley orgánica 1/1996 de protección del menor ${ }^{50}$, los contenidos específicos que pudieran ser motivo de sanción, incluso en el caso de la violencia de género.

Elevando el Estatuto de Autonomía ${ }^{51}$ a Carta Magna andaluza, se puede afirmar con rotundidad que la igualdad de género es una cuestión que se repite de manera constante en el mismo y desgranándose de muy diversas formas: la prohibición de la discriminación, la garantía de igualdad de oportunidades entre hombres y mujeres en todos los ámbitos, la igualdad de mujeres en el empleo, la conciliación de la vida laboral, familiar y personal, el impacto de género, el principio de representación equilibrada entre hombres y mujeres, etc. ${ }^{52}$

Así pues, la transversalidad se propone como criterio de igualdad de género. Ejemplo de ello es el hecho de que es el único texto de esta naturaleza que utiliza un lenguaje no sexista. ${ }^{53}$

${ }^{50}$ Ley Orgánica 1/1996, de 15 de enero, de protección jurídica del menor, de modificación del Código Civil y de la Ley de Enjuiciamiento Civil.

${ }^{51}$ Reforma del Estatuto de Autonomía para Andalucía, aprobado por Ley Orgánica 2/2007, de 19 de marzo, BOJA 56/2007, de 20 de marzo de 2007.

${ }^{52}$ FEDERACIÓN DE ENSEÑANZA DE CC.OO. DE ANDALUCÍA. "Estatuto de Autonomía - Igualdad - Transversalidad". Revista digital para profesionales de la enseñanza. 2010, Nº 6 .

53 MUJERES EN RED, El Estatuto Andaluz tendrá un lenguaje "no sexista" desoyendo las recomendaciones de la $\mathrm{R} A E$ [en línea]. 
El desarrollo normativo del Estatuto en materia de igualdad en los términos que interesan al presente trabajo llega de la mano de la Ley 12/2007 del 26 de noviembre para la Promoción de la Igualdad de Género, así como como de la Ley 1/2004, de 17 de diciembre, de creación del Consejo Audiovisual de Andalucía.

Lamentablemente se ha de reiterar que la falta de concreción legislativa a nivel autonómico y tal y como se verá más adelante en el análisis de las acciones del CAA, e incluso en las propias palabras de su Presidenta en su comparecencia ante la Comisión de Igualdad, Salud y Políticas Sociales del Parlamento de Andalucía ${ }^{54}$, ha dificultado cuando no imposibilitado, el ejercicio de su potestad sancionadora en lo que respecta al tratamiento informativo de la violencia de género.

\section{Actuaciones concretas}

El CAA, a la luz de diversos informes técnicos, realiza un conjunto de acciones conducentes al cumplimiento del marco normativo analizado con anterioridad ${ }^{55}$, concretándose las mismas en decisiones

$<$ http://www.mujeresenred.net/spip.php?article831>[Consulta: 20 de julio de 2013]

${ }^{54}$ Comparecencia de la Sra. Presidenta del Consejo Audiovisual de Andalucía ante la Comisión de igualdad, salud y políticas sociales. Grupo de trabajo relativo al análisis y revisión de la situación y medidas para la promoción de la igualdad de género y contra la violencia de género en Andalucía. 12 de noviembre de 2013.

${ }^{55}$ Recomendaciones del Consejo Audiovisual deAndalucía sobre la aparición de menores en emisiones de televisión y radio relativas a sucesos luctuoso, dramáti cos o relacionados con conductas ilegales. 2009. Recomendaciones del Consejo Audiovisual de Andalucía ante la retransmisión televisiva del juicio oral por la desaparición de Marta del Castillo. 2009 Hacia la puesta en marcha de la "Declaración de la RIRM para promoción de la igualdad de género y la lucha contra los estereotipos sexistas" 23 noviembre 2012

Informe sobre el tratamiento informativo dado por las televisiones al proceso judicial por una denuncia falsa en Málaga 12 noviembre 2014 
y recomendaciones. La dificultad estriba en el hecho constatable de la carencia de instrumentos precisos, más allá de la prohibición expresa de discriminación, que garanticen el tratamiento informativo de calidad que un fenómeno, tan complejo como la violencia contra las mujeres, requiere.

Del informe estadístico sobre la violencia de género, presentado en noviembre de 2014, podemos destacar, antes de entrar a valorar cualitativamente el tratamiento informativo, algunas prácticas profesionales inquietantes.

Si atendemos a la duración de cada noticia, se aprecia que las referidas a violencia de género son más breves, pues duran, en promedio, un minuto y cinco segundos, mientras que la duración general de las noticias es de 1 minuto y 23 segundos, lo que significa que las noticias sobre violencia de género son un $22 \%$ más cortas que las demás, datos idénticos a los registrados en 2012. De lo cual podríamos deducir la falta del tiempo necesario para contextualizar la información. Que la brevedad sea una de las características de la información sobre la violencia contra las mujeres parece incompatible no solo con la necesaria contextualización, sino con la recomendación del propio CAA de que se informe de los recursos existentes, los protocolos establecidos y el teléfono de asesoramiento a las víctimas.

La evolución mensual del número de informaciones sobre violencia de género alcanza sus más altas cotas en noviembre (el día 25 se ha establecido como día internacional contra la violencia de género), con un total de 467 noticias emitidas dedicadas a tratar este tema, es decir,

Informe sobre la presencia de la violencia de género en los informativos de las televisiones públicas andaluzas 201314 noviembre 2014

Decisión 64/2014 del consejo audiovisual de Andalucía sobre presencia de mujeres y hombres en los informativos de las televisiones públicas de Andalucía.

Recomendaciones del Consejo Audiovisual de Andalucía para mejorar la representación de la mujer en la programación informativa 2014.

Recomendación del CAA Derecho a la información y justicia: Guía para el tratamiento informativo de los procesos judiciales. 
una de cada cuatro noticias sobre violencia de género se ha emitido durante el citado mes de 2013. De estos datos se desprende un marcado carácter institucional de la información referida a la violencia de género, que reúne en torno a la efeméride del 25 de noviembre una de cada cuatro noticias de todo el año. Sería conveniente que la información tuviera un carácter menos estacional, se distribuyera durante todo el año. Además debemos destacar la importancia de que la información sobre los casos de violencia tenga un seguimiento y se proporcione información a la audiencia sobre los procesos judiciales y las condenas, aminorando así cualquier sensación de impunidad que pudiera deducirse. Puede ser preocupante el estrecho vínculo establecido entre la celebración de una efeméride, en gran medida de carácter institucional, a la hora de decidir la inclusión en la agenda informativa.

La denuncia de esta agresión generalizada cuestiona la efectividad real del cumplimiento de derechos fundamentales y libertades públicas tan importantes en la CE como el 14 ya analizado, dedicado a la igualdad, y el $17.1^{56}$ que consagra al derecho a la libertad y seguridad ${ }^{57}$. Por otra parte, no solo atenta contra la dignidad de las mujeres, sino también contra el funcionamiento correcto de un estado que considerándose democrático debería garantizar de forma más efectivas los derechos de una parte importante de su población. Para realizar esta tarea de forma correcta es necesario dotarnos de políticas públicas que garanticen la suficiencia de los recursos destinados tanto a la prevención como a la intervención con víctimas. Pero también se hace imprescindible la labor de sensibilización. En esta labor deben estar incluidos los medios de comunicación de masas como agentes socializadores de primer orden. El rigor, la calidad de la información, es imprescindible, para ello se debe contar con un tiempo necesario

${ }^{56}$ Artículo 17.1: Toda persona tiene derecho a la libertad y a la seguridad. Nadie puede ser privado de su libertad, sino con la observancia de lo establecido en este artículo y en los casos y en la forma, previstos en la ley.

${ }^{57}$ A este respecto, es interesante el artículo de Andrés Montero Gómez, "La seguridad como derecho". http://www.mujeresenred.net/spip.php?article1528. Visitada en 22 de enero de 2015. 
para cada noticia pero también es irrenunciable que este tema permanezca como prioritario en la agenda informativa los doce meses del año, no solo en noviembre o cuando se produce un asesinato.

Otra de las prácticas preocupantes, a nuestro entender, es que aún una de cada diez noticias sobre violencia de género esté enmarcada en la sección de sucesos. Lo que a nuestro juicio merma la consideración de que cada caso de violencia debe ser tratado como parte de un fenómeno social complejo.

La fuerte presencia de fuentes irrelevantes para la información lo corrobora el hecho de que el primer puesto en importancia en las noticias sobre violencia de género lo ocupa el rol de actores ocasionales, con un promedio del 18\% del tiempo de palabra frente al $13 \%$ del resto de las noticias. Situación aún más preocupante dado que la presencia de fuentes expertas disminuye su cuota de tiempo a un $9,5 \%$. A pesar de la fuerte feminización de las fuentes consultadas para este tipo de noticias $(66 \%$ en las noticias sobre violencia de género frente al 29\% en el resto de noticias). La segregación por sexo de esas fuentes también nos arroja un sesgo que podríamos considerar poco favorecedor desde una perspectiva feminista: las mujeres suponen el $73 \%$ de los actores ocasionales pero solo el $64 \%$ de las fuentes expertas.

\section{Las acciones en torno a la correcta cobertura de este tipo de información se encuentran en el apartado de 'contenidos discriminatorios'}

Este panorama trazado en el análisis del propio informe del CAA nos proporciona datos suficientes para realizar una valoración de carácter general y una serie de consideraciones que expondremos a continuación.

El principal problema a nuestro entender es la falta de medios jurídicos con el que se enfrenta el CAA a la hora de realizar una labor eficaz de control que conduzca a un correcto tratamiento de este tipo de información, en palabras de su presidenta:

“Al Consejo Audiovisual de Andalucía le está resultando difícil 
actuar en materia de igualdad debido al escaso compromiso de los propios medios de comunicación, en muchos casos por la indefinición de los conceptos y la ausencia de consenso sobre indicadores y metodologías que permitan medir objetivamente, evaluar y corregir el sexismo y la discriminación" 58

Esta indefinición abunda de facto en la imposibilidad de actuar ante los tratamientos incorrectos y revictimizadores que en muchas ocasiones se ofrecen sobre la violencia contra las mujeres.

El abordaje de esta cuestión, aún en el marco jurídico de contrastada ineficacia ante esta cuestión ${ }^{59}$, a nuestro entender pasaría por considerar la necesidad de establecer un apartado de trabajo específico, fuera del demasiado general y poco ajustado "contenidos discriminatorios". No se trata tanto de detectar discriminación en los contenidos emitidos, como de avanzar hacia un tratamiento correcto que ayude a la ciudadanía a comprender la complejidad del fenómeno $y$, por tanto, redunde en una necesaria función educativa de los medios. Hay elementos del tratamiento informativo que va más allá de contenidos discriminatorios analizados desde una perspectiva feminista. La construcción de un nuevo discurso informativo pasa por la consideración de formular propuestas en positivo para garantizar en el ámbito de lo simbólico la igualdad de género, por eso reiteramos que su inclusión no diferenciada en el apartado de "contenidos discriminatorios" no favorece esta propuesta. Es necesario subrayar que no solo los elementos cuantitativos, con ser tan reveladores como los del Informe de 2013, son suficientes. Lo

\footnotetext{
58 Óp. cit.

59 «La violencia de género no sólo ha perdido en general relevancia informativa, lo cual nos parece una deriva más que preocupante, sino que el tratamiento que algunos programas han dado a casos concretos, como el asesinato de una menor en El Salobral, nos ha llevado a reclamar al Parlamento de este país que abra un debate riguroso sobre la necesidad de abordar la regulación de los medios de comunicación en este campo.» Ibídem Nota anterior.
} 
cualitativo debe ser al menos tan relevante, si no más, frente a las mediciones de carácter cuantitativo.

La segunda acción planteada, bien que se trate de una propuesta de mínimos es entrar en un pacto de corregulación, a la espera de una modificación legislativa, que se base en un documento donde se establezcan las indicaciones que permitan abordar el tratamiento informativo de la violencia de género en las mejores condiciones posibles.

Las entrevistas a profesionales a lo largo de los últimos años, en diversos proyectos de investigación, nos hacen concluir que, en muchas ocasiones, es la falta de formación de los profesionales sobre este tema lo que condiciona el mal tratamiento ofrecido.

Esta constatación nos lleva a realizar la propuesta de una tercera acción. La necesidad imperiosa de exigir que los profesionales de la comunicación reciban formación específica en igualdad de género y en el correcto tratamiento de la violencia contra las mujeres. La gravedad del tema, y los insuficientes medios jurídicos disponibles, hacen necesaria la adopción de medidas que como la formación, puedan ayudar a resolver, o al menos paliar, parte del problema derivado del incorrecto tratamiento informativo ofrecido con mucha frecuencia. Ahí el CAA puede realizar una labor no solo propositiva sino también ejecutiva, cuestión que podría incorporarse a la futura ley audiovisual en relación a las competencias del CAA, puesto que actualmente la formación no es una de sus funciones, ni en consecuencia tiene el Consejo los recursos suficientes para abordarla.

Tenemos que ser conscientes que la cuestión que planteamos afecta de forma general a la calidad de nuestra democracia y que la espectacularización de la información es una deriva que no afecta exclusivamente a las cuestiones de igualdad de género. Pero en este terreno tan sensible, y que de una forma u otra, afecta a gran parte de la población andaluza, se pone de relieve, casi de manera paradigmática, las graves consecuencias de no tomar medidas para garantizar derechos humanos, y por supuesto, derechos 
fundamentales recogidos en la CE, cuando nos trasladamos al ámbito de los medios de comunicación.

De la importancia que los medios tienen en la concienciación sobre la dimensión del fenómeno nos da cuenta el caso de Ana Orantes. Verdadero punto de inflexión en la relación entre medios de comunicación y violencia de género

"Hay un antes y un después de la muerte de Ana Orantes. La gente vio en la televisión a una mujer normal, arreglada y bien vestida que contaba su tragedia familiar, y a los pocos días conocieron su asesinato en unas circunstancias especialmente violentas", dice el forense y especialista en violencia de género Miguel Lorente. "Con ella, estos asesinatos dejaron de considerarse casos aislados de la España negra para convertirse en fenómeno cultural y social que puede afectar a cualquiera. Debemos a Ana Orantes este cambio de perspectiva". ${ }^{60}$

Las competencias en materia de violencia de género dentro del organigrama de la Junta de Andalucía competen a la Dirección General de Violencia de Género, adscrita a la Consejería de Justicia. No obstante, es el Instituto Andaluz de la Mujer quien las tuvo en sus inicios, razón por la cual el código deontológico en relación al tratamiento informativo de la violencia de género es del IAM. A tenor de la investigación, y en relación al tema que nos ocupa, parece evidente que la división competencial no favorece un efectivo cumplimiento institucional sobre la materia.

En cualquier caso, la actual colaboración debería estrecharse para proporcionar los instrumentos técnicos que puedan facilitar el mejor tratamiento informativo. El Instituto Andaluz de la Mujer, aun habiendo elaborado un decálogo para el correcto tratamiento informativo de la violencia de género, ha dedicado poca atención a

${ }^{60}$ Altozano, Manuel “400 muertes después”. El País 25 noviembre 2004 
esta cuestión. Esto se infiere del hecho que el código posee más de quince años de antigüedad y que muchas de sus recomendaciones han quedado obsoletas, e incluso pueden considerarse contraproducentes, a la luz de diversas investigaciones realizadas en los últimos años. Y no solo en el campo de la comunicación, sino asimismo en disciplinas como la psicología, la sociología, el derecho,...

Nuestra recomendación acerca del correcto tratamiento informativo de la violencia de género pasa por subrayar la necesaria colaboración de las instituciones implicadas, los medios y la sociedad civil. Todo ello conducirá sin lugar a dudas a avanzar a pesar de las dificultades técnicas expuestas con anterioridad.

Somos conscientes de las limitaciones que nuestra propuesta encarna, incluso en el hipotético caso de que se legislara, por parte de la cámara parlamentaria andaluza. La inexistencia de leyes marco estatales, e incluso la propia inexistencia de un Consejo Audiovisual con competencias en el conjunto del estado, merma la eficacia de estas medidas que solo podrían ser eficaces sobre los operadores que tiene su domicilio jurídico en Andalucía.

Los numerosos ejemplos sobre tratamiento espectacular y morboso de la información relacionada con la violencia machista pueden quedar reflejados perfectamente en una de las acciones del CAA con motivo del asesinato de una menor en El Salobral (Albacete) en 2012. La reprobación tramitada ${ }^{61}$ afectaba sobre todo a los magacines de franja de mañana Espejo Público y El Programa de Ana Rosa, aunque el hecho de ser una menor implicada facilitó la remisión a la fiscalía de esta decisión por si cupieran medidas penales contra Antena 3 y Tele 5. La decisión pone de relieve en su análisis el incorrecto tratamiento informativo desde la perspectiva de la protección de las víctimas y la revictimización provocada por el mismo. Constata la falta de rigor, la espectacularización, el tratamiento morboso y la total ausencia de

${ }^{61}$ Decisión 28/2012 Del Consejo Audiovisual De Andalucía Sobre Tratamiento Informativo Dado Al Asesinato De Una Menor Víctima De Violencia De Género. 
respeto a los derechos de la víctima. La intervención de los tribunales para lo protección de derechos fundamentales ha sido posible en este caso por la existencia de una ley orgánica de protección del menor ${ }^{62}$ que permite actuar. Este ejemplo nos sirve también para mostrar la necesidad de legislar en el caso de victimas adultas para una mayor eficacia de sus derechos.

Por último, se destaca el código en materia de tratamiento informativo de la violencia de género inserto en la 'Recomendación del CAA Derecho a la información y justicia: Guía para el tratamiento informativo de los procesos judiciales', como un apunte de hacía donde se debería dirigir la acción legislativa en esta materia.

\section{Conclusiones}

\section{De investigación}

Nuestras conclusiones se infieren del propio relato de las dificultades con las que se encuentra el CAA a la hora de tomar medidas sancionadoras pero sobre todo preventivas que eviten en la medida de lo posible los tratamientos informativos correctos. Para ello, pues, sería necesario mejorar la protección jurídica con una regulación más exhaustiva y sobre todo concreta.

Siendo conscientes que éste es el camino más deseable, podría mientras tanto mejorarse la situación con formación específica destinada a los y las profesionales de los medios y un pacto de corregulación que se asiente en un código que atienda a los elementos técnicos aportados por las investigadoras que trabajan en esta línea en los últimos años. ${ }^{63}$

\section{$\underline{\text { Feministas }}$}

${ }^{62}$ Óp. Cit Ley Orgánica 1/1996, de 15 de enero, de protección jurídica del menor, de modificación del Código Civil y de la Ley de Enjuiciamiento Civil.

${ }^{63}$ Adjuntamos al final de nuestro texto una propuesta de mínimos codificada en un decálogo a la luz de nuestro trabajo de investigación en esta línea. 
Se hace necesario implicar a la sociedad civil organizada a través de las asociaciones feministas en el papel de concienciación ciudadana de la responsabilidad que los medios de comunicación poseen a la hora tanto de sensibilizar a la ciudadanía en cuestiones referidas a la creación de un discurso público en torno a la violencia de género en consonancia con un estado democrático que dice poner su énfasis en las cuestiones de igualdad entre hombres y mujeres.

Las organizaciones feministas deben cumplir asimismo un papel importante en la denuncia del incumplimiento de los medios, como titulares de derechos fundamentales, de un comportamiento que abunde en la calidad democrática de nuestro estado. La banalización, la espectacularización, la falta de rigor e independencia de los medios de comunicación es uno de los síntomas pero también de las causas del deterioro democrático sufrido en los últimos años.

\section{Referencias bibliográficas}

ALVAREZ CONDE, Enrique et al. Mujer y Constitución en España. Centro de Estudios Políticos y Constitucionales, Madrid, 2000.

AREDNT, Hannah. Los orígenes del totalitarismo, 2. Imperialismo. Madrid, Alianza Editorial, 1987

CARTER Cynthia. y STEINER Linda, (eds). Critical readings. Media and gender. Londres, Open University Press, 2004

JIMENA QUESADA, Luis y TOMÁS MALLÉN, Beatriz. "Hacia un estándar europeo común de igualdad: la contribución del comité europeo de derechos sociales". Revista de Derecho Político. 2007, No 68

PECES-BARBA MARTÍNEZ, Gregorio, et. al. Curso de Derechos Fundamentales. Teoría General. Madrid, Universidad Carlos III, 1999

SAEZ LARA, Carmen. Mujeres y mercado de trabajo: las discriminaciones directas e indirectas. Bruselas, Consejo económico y social, 1994 
Anexo

\section{Decálogo}

1.- La información debe ser contextualizada, no como un hecho aislado sino como una agresión extrema en el contexto de la violencia estructural, simbólica, psicológica y física producto de las relaciones patriarcales.

2.- La violencia contra las mujeres es una grave vulneración de los derechos humanos, que atenta contra los derechos de igualdad y libertad de las mujeres. La información debe presentarse de forma que preserve y promueva la dignidad de las mujeres.

3.- La información sobre la violencia machista debe evitar la espectacularización. Esta información debe rehuir la inclusión de datos no relevantes que puedan abundar en un tratamiento morboso.

4.- Se debe presentar los casos de violencia como delitos, evitando prejuicios y estereotipos étnicos, culturales o de cualquier índole personal o sociocultural tanto de víctimas como de agresores. Se debe evitar también presentar móviles que parezcan justificar el delito y desvíen la culpa del agresor.

5.- Se debe acompañar la información con análisis de expertos (principalmente expertas), que ayuden a contextualizar estos hechos, tal y como se manifiesta en la primera recomendación. Esta contextualización debe ser interdisciplinar y rigurosa, rehuyendo los testimonios de familiares y vecinos no relevantes para una mejor comprensión del fenómeno.

6.- La presunción de inocencia no debe dar amparo a la sensación de impunidad. Se debe por tanto dar cobertura también a los procesos judiciales y las condenas que de éstos deriven.

7.- La información debe estar orientada para concienciar a la población sobre la necesidad de denunciar. No solo las mujeres víctimas, sino la sociedad en general. 
8.- El tratamiento informativo debe perseguir la creación de una conciencia social con respecto a la violencia contra las mujeres, que derive en un rechazo a toda violencia de género.

9.- La cobertura de información de todos los casos de violencias contra las mujeres debe incorporar información de los recursos públicos existentes, teléfonos de emergencia y protocolos previstos.

10.- Las políticas públicas en materia de igualdad y especialmente las de prevención de violencia de género y atención a las víctimas deben estar incorporadas a las agendas de los medios, como hechos noticiosos en sí mismos al margen de la información sobre casos concretos de violencia contra las mujeres. 



\title{
Mediciones e índices de evaluación inclusivos: examen de los indicadores de género y medios de comunicación
}

\author{
Ruth Ainhoa de Frutos García \\ Universidad de Málaga
}

\begin{abstract}
T A globalización, el desarrollo tecnológico y la crisis actual han generado un escenario mediático inédito que debe ser analizado pormenorizadamente con el objetivo de beneficiar a la ciudadanía, a los poderes públicos y a los propios medios de comunicación. No obstante, la desigualdad de las relaciones de poder entre ambos sexos, generada por el patriarcado, ha situado a las mujeres en una situación de desventaja y subordinación ${ }^{64}$ que suele invisibilizarla en este tipo de evaluaciones de la realidad mediática.
\end{abstract}

\footnotetext{
${ }^{64}$ Como describe Castells, el mundo de las mujeres como "una cultura propia hecha de observación subordinada y comportamiento estratégico a partir de una información más variopinta que las de los hombres y de los atributos en los que tenían ventaja comparativa, desde la seducción hasta el socorro del frágil ego masculino" (CASTELLS 2007: 13). Desde la teoría social crítica de Freire (1970), Gramsci (1971), Foucault (1980) y otros, se asume, en concordancia con teorías feministas y de género, que la conquista del poder y el empoderamiento de las mujeres, en las misma proporción que la de los hombres, debe fomentarse desde la ciudadanía en general, con el objetivo de que las mujeres
} 
Antes de entrar en el debate sobre los estudios que crean sinergias entre la comunicación y el género, es necesario aludir a que las desigualdades que se producen relacionadas con estas cuestiones no son más que otra representación del discurso hegemónico en los medios. Por tanto, la invisibilización de toda persona por razón de sexo, identidad de género u orientación afectivo-sexual en la esfera mediática representa un espejo del contexto donde se enmarcan dichos medios.

Llegados a este punto es importante destacar la figura de Michèle Mattelart, compañera de Armand Mattelart y coautora de muchos de sus textos. Mujeres e industrias culturales, es un trabajo que Michèle Mattelart realizó en 1981, por encargo de la División para el Desarrollo Cultural de la UNESCO, en la que partía de la hipótesis de que los medios de comunicación están condicionados histórica y socialmente para responder a las necesidades de un sistema que relega a la mujer a un segundo plano (MATTELART, 1981).

La problemática de la igualdad de género ha sido una constante en los estudios realizados por órganos de reconocido prestigio. Sin embargo, ante la ausencia de modelos generales para analizar el estado de la mujer en los medios de comunicación y las limitaciones de los existentes, el análisis documental que se presenta a continuación se ha centrado en los Indicadores de género para medios de comunicación elaborado por UNESCO (2012a), complementado con el análisis de otros informes y documentos del PNUD, UNESCO, la Comisión Económica para Europa de Naciones Unidas ${ }^{65}$ (CEPE), el Instituto Europeo para la Igualdad de Género (EIGE) etc., así como otros

participen en la producción no solo doméstica, acabando con cualquier tipo de conflicto sexista o de identidad de género.

${ }^{65}$ En enero de 2014 la CEPE presentó el borrador de los Indicadores de Igualdad de género entre los que se encuentra una categoría especializada en medios de comunicación (CEPE 2014). La secretaría presentó las conclusiones en la Sesión de Trabajo de la CEPE sobre estadísticas de género (Ginebra, 1921 de marzo 2014) y, posteriormente, en la sesión plenaria de la Conferencia de Estadísticos Europeos (París, 9-11 de abril 2014). 
observadores de esta realidad, como las ONG Social Watch o International Women's Media Foundation (Figura 1)

FIGURA 1. ÍNDICES DE GÉNERO Y MEDIOS DE COMUNICACIÓN ANALIZADOS

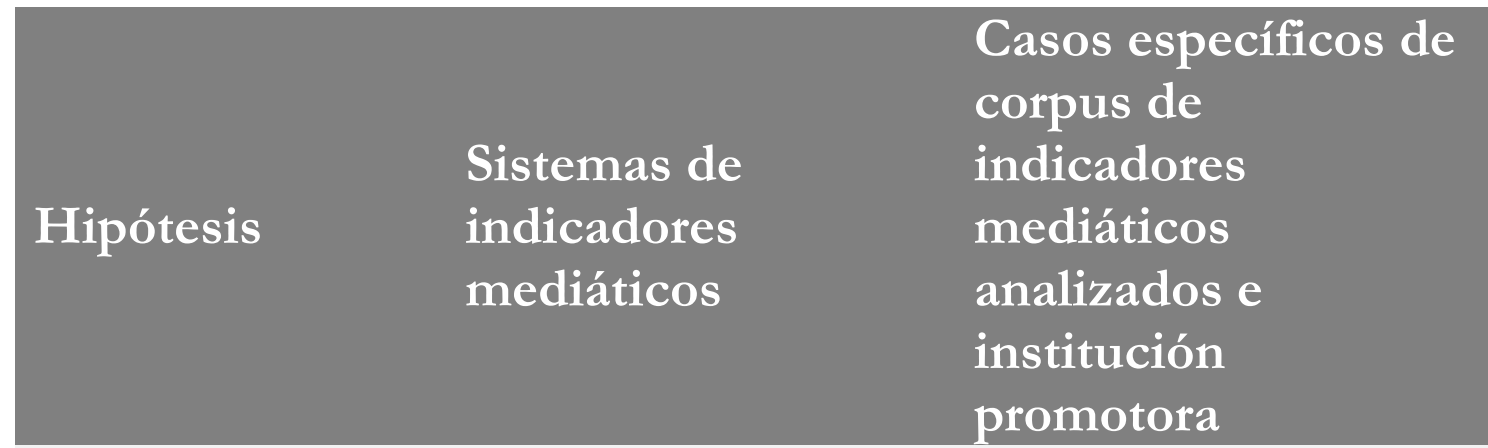

Los indicadores

mediáticos están

llamados a

Indicadores de

evolucionar en la género en medios de dirección de la comunicación igualdad de género

Indicadores de género para medios de comunicación UNESCO Índice de Equidad de Género

Social Watch

Indicadores de igualdad de género Comisión Económica para Europa de Naciones Unidas

Global Report on the Status Women in the News Media

Women's Media

Foundation

Elaboración propia. 
Históricamente, el PNUD ha sido una de las organizaciones internacionales que más se ha preocupado por la equidad de género fomentando la transversalización de la perspectiva de género:

"Valorar las implicaciones que tiene para los hombres y las mujeres cualquier acción que se planifique, ya sea que se trate de legislación, políticas o programas, en todas las áreas y en todos los niveles. Es una estrategia para conseguir que las preocupaciones y experiencias de las mujeres, al igual que las de los hombres, sean parte integrante en la elaboración, puesta en marcha, control y evaluación de las políticas y de los programas en todas las esferas políticas, económicas y sociales, de manera que estos puedan beneficiarse de ellos igualmente y no se perpetúe la desigualdad" (DEFINICIÓN ADOPTADA POR EL CONSEJO ECONÓMICO Y SOCIAL DE LAS NACIONES UNIDAS, ECOSOC 1997).

En 1995, el PNUD diseñó dos indicadores para evaluar la igualdad entre hombres y mujeres ${ }^{66}$, dentro de su Informe de Desarrollo Humano (IDH). Casi dos décadas después, numerosas organizaciones internacionales, regionales y nacionales han desarrollado su propio sistema de indicadores con el fin de evaluar la situación de la mujer en distintos entornos ${ }^{67}$.

${ }^{66}$ El PNUD creó del Índice de Desarrollo ajustado por Género (Gender-Related Development Index, en inglés) y el índice de Potenciación de Género (Gender Empowerment Measure) a través de los cuales se sitúa a los diferentes países en un ranking de mayor a menor en función de la situación de (des)igualdad de las mujeres.

${ }^{67}$ El lanzamiento de los Indicadores de género para medios de Comunicación (UNESCO 2012a) posibilita a las redacciones de los medios de comunicación pero también a estudiosos y organismos internacionales a realizar sus propias investigaciones y denuncias sobre el papel de la mujer y, al mismo tiempo, realizar estudios comparados e incrementar el empoderamiento de la mujer no solo como profesional de los medios sino también como contenido de las noticias. Prueba del aumento del interés internacional por este tipo de cuestiones es que desde 1995, fecha en la que se puso en marcha el primer 
De hecho, "promover la igualdad entre sexos y el empoderamiento de la mujer" es el tercer objetivo de los Objetivos de Desarrollo del Milenio promovidos por el PNUD para 2015. La igualdad de género es no solo un objetivo en sí mismo, sino también un medio importante para lograr todos los demás Objetivos de Desarrollo del Milenio. La igualdad de género es, por tanto, un pilar básico en todo Estado Social y Democrático de Derecho. Se convierte en una máxima del sistema la eliminación de obstáculos entre hombres y mujeres en todos los poderes del Estado y, por ello, una de las hipótesis principales de esta investigación es que los indicadores están llamados a evolucionar en la dirección de medir los valores que hoy distinguen el desarrollo mediático, como son la transparencia, la igualdad de género, la democracia y la cultura de paz, determinantes para el nuevo paradigma social (DíAZ NOSTY, 2013).

El periodismo y los medios ${ }^{68}$ se enfrentan a múltiples desafíos en un mundo rápidamente cambiante donde medios nuevos y tradicionales están convergiendo con consecuencias impredecibles. En este sentido, integrar la rendición de cuentas por los medios a la lucha de género e igualdad de género debe ser un impulso para afrontar los nuevos paradigmas sociales (CEPE, 2014: 104; GMMP, 2010: v). Michèle Mattelart vuelve a perfilar un orden de representación simbólica impulsado principalmente por el discurso hegemónico de

Proyecto de Monitoreo Global de Medios estuvo bajo la coordinación de la ONG canadiense Media Watch, pionera en observación de los medios, con el apoyo de la WACC entre otras organizaciones se realizan periódicamente estudios en los que el papel de la mujer mejora lentamente.

${ }^{68}$ De igual modo, los medios de comunicación juegan un papel fundamental en la dinámica del mundo globalizado y facilitan su comprensión a la opinión pública. Así, dicha dinámica democrática "no sería posible sin libre circulación de información, ni los conceptos modernos de cultura y educación se entenderían igual sin la presencia activa del 'periodismo' y, aunque se discute mucho si los medios crean la opinión pública o la siguen y confirman, en el estado actual de la cuestión es innegable que existe una relación circular e interactiva entre ambos fenómenos" (LOSCERTALES, 2009: 19). 
los medios, para lograr la creación de la mujer-objeto o su completa invisibilización en el ámbito mediático ${ }^{69}$ (MATTELART, 2014).

El proyecto de supervisión de los medios de difusión a nivel mundial (GMMP) 2010 ya ofreció algunos datos que hacían presagiar la importancia de las mediciones con perspectiva de género ${ }^{70}$. Solo por citar algunos ejemplos, los hombres ocupaban casi el 61,3\% de los cargos de alta dirección, mientras que las mujeres eran el 38,7\%. Respecto al nivel medio en el cuadro orgánico, los hombres dominaban el porcentaje, con un $63,9 \%$ mientras que las mujeres solo desempeñaban el 36,1\% de los cargos. En el área profesional técnica, los hombres poseían el $73,25 \%$ de los empleos, mientras que las mujeres apenas rondaban el 26,8\% (GMMP, 2010: xi).

\section{De los indicadores de desarrollo mediático a los indicadores de género para medios de comunicación de UNESCO}

${ }^{69}$ La autora volvió a defender esta tesis en su discurso de investidura como Honoris Causa en la Universidad de Málaga el pasado 28 de abril de 2014, aludiendo a que la Comunicación debe servir como una herramienta para el cambio en las relaciones sociales entre hombres y mujeres. Asimismo, criticó el serial melodramático, que "desempeñó un papel fundamental para la infravaloración de las mujeres en la cultura". Del mismo modo, criticó que los estudios sobre mujer y género deban coexistir con áreas marginales ya que, según la autora, "no están en la periferia sino en el centro del discurso progresista” (MATTELART, 2014, discurso Honoris Causa).

${ }^{70}$ El cuarto GMMP ha atestiguado una explosión en cuanto a la participación. Este informe incluye 43 países que son nuevos participantes. La participación se amplió significativamente en África, particularmente con países francófonos. El incremento de países también se dio en Asia, El Caribe, Europa, Oriente Medio, África del Norte y la región Pacífico. Vale la pena destacar en particular el incremento de la participación en países árabes. En el prefacio al informe del GMMP 2005, Anna Turley, anterior coordinadora del Programa de Mujeres de la WACC escribió: "Si brotan [pequeños] avances de una conciencia que considere que la representación actual del género en las noticias es algo que hay que cuestionar, más que darla por sentado, tienen potencial de ser transformadores. El cambio no van a suceder de la noche a la mañana, sin embargo, el GMMP nos acerca un paso más a dicha transformación” (GMMP 2010: VI). 
La igualdad de género ha sido una línea de trabajo constante para UNESCO. Con todo, desde la designación de la igualdad de género como una de las dos prioridades globales de la organización en su estrategia para los años 2008-2013 ${ }^{71}$, ha aumentado el número de publicaciones internacionales y de intentos por visibilizar los derechos de las mujeres. Esta prioridad se basa en dos frentes: (i) programas específicos de género y (ii) colocar los asuntos de género en el centro del debate con acciones en todos los campos de competencia de UNESCO: educación, ciencias, cultura, comunicación e información a todos los niveles ${ }^{72}$.

De hecho, los indicadores de género para medios de comunicación no son más que una extensión de los Indicadores de Desarrollo Mediático realizados por UNESCO de 2008 (GRIZZLE, 2012). Dichas herramientas de medición hacen referencia al Guide to Measuring the Impact of Right to Information Programmes (PNUD, 2006a) en la que se enumeran diversos aspectos para perfilar las herramientas que hacen referencia al género como indicadores específicos ${ }^{73}$. El PNUD afirma

${ }^{71}$ La propia organización ha creado un documento llamado "Plan Prioritario de Igualdad de Género 2008-2013" que proporciona una "hoja de ruta" para traducir esta prioridad en acciones concretas que den resultados para los 6 años que cubre dicha estrategia a medio plazo.

${ }^{72}$ UNESCO ha planteado medidas desde la intervención en políticas de desarrollo, a concienciación y apoyo a la investigación, pasando por el reforzamiento institucional de la capacitación y la preparación a las mujeres. Para más información consultar Plan de acción para la equidad entre géneros (UNESCO 2008b).

${ }^{73}$ Esta publicación fue desarrollada por el PNUD basándose en la creencia de que "el derecho a la información es fundamental para reforzar los principios democráticos de apertura, transparencia y rendición de cuentas de las sociedades y en la erradicación de la pobreza". Esta guía complementa una publicación anterior, Practical Guidance Note on Right to Information que proporciona orientación sobre los enfoques para el diseño y ejecución de programas en este ámbito. La guía establece los principios básicos de la evaluación de programas, centrándose en la evaluación de los resultados. En ella se esbozan cuatro grandes áreas relacionadas con el derecho a la información: El régimen jurídico del derecho a la información; la aplicación del derecho a la información en la legislación por parte del gobierno, el uso del 
que los organismos oficiales deben de observar estas diferencias entre hombres y mujeres para responder mejor a las necesidades concretas de información de las mujeres y a sus deficiencias a través de métodos alternativos. Por ejemplo, la información sobre salud sexual puede ser distribuida a través de medios no convencionales como el teatro o, en el caso de la información sobre los pagos a los centros de salud locales, éstos podrían ser explicados en el tablón de anuncios de la clínica, donde la mujer podría leerla directamente.

La celebración del Día Internacional de la Mujer de 2010 fue un punto de inflexión para los indicadores de género para los medios. UNESCO y un grupo de organizaciones internacionales realizaron la iniciativa "Las mujeres hacen las noticias", a través de una campaña internacional, con el objetivo de generar buenas prácticas desde la perspectiva de género en los medios (UNESCO, 2010). De hecho, dicha iniciativa fue la primera que se posicionó abiertamente sobre la necesidad de indicadores con una perspectiva de género sobre los medios de comunicación. Ello dio como resultado una consulta online abierta con el fin de obtener la mayor parte de información posible para continuar con la siguiente fase: el borrador.

UNESCO, en colaboración con la Federación Internacional de Periodistas, organizó en 2011 una consulta a partir del primer borrador para diseñar lo que se convirtió en el segundo y último borrador de los Indicadores de género para medios de comunicación que fueron publicados ese año (Gender-Sensitive Indicators for Media ${ }^{74}$, GSIM según sus siglas en inglés). Esta segunda versión del borrador fue origen de otra consulta virtual con asociaciones de medios escritos, uniones y asociaciones de profesionales y de estudiosos de

derecho a la información por la población y la sociedad civil, el uso del derecho a la información por grupos marginados.

${ }^{74}$ El 14 y 15 de abril de 2011, 17 expertos en representación de medios de comunicación y organizaciones de estudios de género nacionales, regionales y locales participaron en la primera ronda de consultas de lo que posteriormente se convirtió en el informe Gender-Sensitive Indicators for Media: Framework of Indicators to Galige Gender Sensitivity in Media Operation and Content (UNESCO, 2012). 
temas de género que, tras observar y revisar el texto, dio lugar a la preparación de la versión final del documento ${ }^{75}$.

\section{Concepción ideológica}

Los GSIM deben convertirse, según UNESCO en herramientas específicas diseñadas para aumentar el acceso y la protección de las mujeres en los medios de comunicación. Tal y como se describe en el informe, los GSIM son un conjunto de indicadores (UNESCO 2012: 16), que pretenden ayudar a las organizaciones y a los profesionales de la información a aumentar la perspectiva de género en los medios, entendiéndola como la participación equitativa de las mujeres en las estructuras mediáticas, pero también en los contenidos.

"The aim of the Gender-Sensitive Indicators for Media is to contribute to gender equality and women's empowerment in and through media of all forms, irrespective of the tecnology used" "76 (UNESCO, 2012: 14).

${ }^{75}$ Solo por citar un ejemplo, los GSIM están siendo aplicados en la actualidad en el entorno mediático uruguayo, como continuación de la aplicación de los IDM en este país. La investigación que monitoreará la situación del género en los medios de comunicación del país latinoamericano ha sido financiada por la AECID.

76 "El objetivo de los indicadores de género para medios de comunicación es el de contribuir a la igualdad de género y al empoderamiento de las mujeres en los medios en todas sus formas, independientemente de la tecnología utilizada" (UNESCO 2012: 14) (Traducción propia). 
FIGURA 2. COMPARACIÓN ENTRE LOS GSIM (UNESCO 2012) Y LOS INDICADORES PROPUESTOS POR LA COMISIÓN ECONÓMICA PARA EUROPA DE NACIONES UNIDAS
Indicadores de Género
Borrador de los Indicadores de
para Medios de
Comunicación
Género
CEPE | 2014

UNESCO | 2012

Categoría A: Acciones para fomentar la igualdad de género en las organizaciones de medios de comunicación

A1 | Igualdad de género en el A.9.2.3 Participación en el sector nivel de toma de decisiones mediático $^{77}$

A2 | Igualdad de género en el trabajo y en las condiciones laborales

A3 | Igualdad de género en los sindicatos, las asociaciones y organizaciones de periodistas, otros profesionales de los medios de comunicación y organismos de autorregulación de los medios A4 Los medios de A.9.2.3 Participación en el sector

\footnotetext{
${ }^{77} \mathrm{El}$ número y porcentaje de periodistas disgregado por sexo es el único indicador disponible sobre la participación en el sector mediático. La CEPE dispone de datos sobre la mitad de los países de miembros. Sin embargo, no todos los periodistas trabajan en el sector mediático. Mientras que la encuesta de población activa podría ser utilizada como una fuente de información sobre la igualdad de género de las personas que trabajan en el sector mediático, esta cifra no muestra la segregación vertical que pueden existir dentro de este sector entre hombres y mujeres (CEPE 2014: 108). La CEPE no propone un indicador específico para esta área ya que utiliza los datos de EIGE (2013, 2014), incluyendo la representación de las mujeres en los medios de comunicación y organismos relacionados.
} 
comunicación promueven

códigos y políticas éticas a

favor de la igualdad de género

en el contenido de los medios

de comunicación

A5 | Igualdad de género en la educación y la formación

\section{Categoría B: Representación del género en los contenidos mediáticos \\ B1 | Representación del género A.9.2.2 | Estereotipos y en noticias y temas de actualidad representación de las mujeres (medida indirecta basada en actitudes sociales)}

2 | Representación de género en la publicidad

A.9.2.1 | Consumo mediático ${ }^{78}$

Porcentaje de personas que utilizan teléfonos móviles Porcentaje de personas que usan internet disgregado por sexo Estereotipos y la representación de hombres y mujeres Actitudes de las mujeres y los hombres, con respecto a las siguientes opiniones:

\footnotetext{
${ }^{78}$ No existe ninguna fuente de los datos desagregados por sexo sobre el uso del teléfono móvil, a excepción de los países de la UE procedentes de Eurostat. Además, el Global Minimum Set incluye un indicador sobre la proporción de hogares con acceso a medios de comunicación (radio, TV, internet), por sexo del cabeza de familia. Sin embargo, a raíz de las recientes recomendaciones de la Conferencia de Estadísticos Europeos (CES 2010) con respecto a la promoción del concepto de referencia del hogar y la dificultad que esto implicaría en la medición de las diferencias de género, la CEPE propone este indicador de apoyo (CEPE 2014: 108).
} 
- Cuando los padres lo necesitan, las hijas deben asumir más responsabilidad que los hijos

- Si una mujer gana más que su pareja, no es bueno para la relación

- En general, los hombres son mejores líderes políticos que las mujeres

- Las mujeres deben ser capaces de decidir cómo gastar el dinero sin preguntar a la pareja

- Cuando los empleos escasean, los hombres tienen más derecho

Elaboración propia a trabajar que las mujeres

Los GSIM se han dividido en dos grandes categorías: Categoría A, "acciones para fomentar la igualdad de género en las organizaciones de medios de comunicación" (dividida en cinco subcategorías) y Categoría B," representación del género en los contenidos mediáticos" (dos subcategorías) (UNESCO, 2012: 21 y ss.). Para afinar el análisis documental de estos indicadores es necesario ampliar la información sobre el perfil de los especialistas que realizaron los GSIM así como analizar críticamente su contenido mediante la doble perspectiva procedente de la esfera comunicacional y de los estudios de género.

Analizando someramente el contenido de los indicadores, se puede decir que se asemejan más a las herramientas de evaluación utilizadas por el Proyecto de Monitoreo Global de Medios (GMMP, por sus siglas en inglés) realizado en 110 países o a los Indicadores de igualdad de género presentados por la Comisión Económica para Europa de Naciones Unidas en 2014, que a los instrumentos utilizados por la ONG Social Watch, ya que esta última analiza desde 
2007 si los hombres y las mujeres tienen asignadas diferentes responsabilidades, derechos, beneficios y oportunidades en las actividades que realizan, en el acceso al control de los recursos y en los procesos de toma de decisiones, mediante el Índice de Equidad de Género (IEG).

Por tanto, mientras los GSIM examinan la situación del género en los medios de comunicación, el IEG evalúa la inequidad de género en las dimensiones educación, participación económica y empoderamiento, basándose en información disponible y comparable a nivel internacional, lo que permite posicionar y clasificar a los países en un ranking. Como sucedía con los indicadores de desarrollo mediático (UNESCO 2008a), los GSIM no tienen como fin último la realización de una clasificación mundial de los países que han sido evaluados a través de dichos instrumentos, sino que pretenden realizar una fotografía de la situación de las mujeres en los entornos mediáticos analizados ${ }^{79}$.

En segundo lugar, se realizará una breve comparación entre los indicadores de género propuestos por UNESCO y los Indicadores de Igualdad de Género (IDG) de la CEPE, aprobados en 2014. Los IDG se encuentran a medio camino entre los IEG de Social Watch y los GMMP de la International Women's Media Foundation al introducir los medios de comunicación como uno de los tantos ámbitos en los que se estudia la igualdad de género. En este sentido, se alejan de los IEG al incorporar los medios como una de las categorías de análisis pero no llegan a ser tan específicos como los GMMP al considerar otras cuestiones como la pobreza, la educación, comunicación, la CEPE obtiene sus indicadores sobre igualdad de género y medios de comunicación a partir de conjuntos de

\footnotetext{
${ }^{79}$ Hay numerosas investigaciones sobre la fotografía fija de las mujeres en los medios de comunicación. A escala nacional, podríamos citar los trabajos de la profesora María Teresa Vera "Periodistas en transición. Expectativas sociolaborales y de género en los inicios de las emisiones de TVE en Andalucía" (2014) o "El perfil de las periodistas en Andalucía: formación y expectativas laborales. Un balance, 1989-2009" (2009b) o el trabajo de la profesora Ana Jorge Alonso Mujeres en los medios, mujeres de los medios (2004).
} 
indicadores existentes, por lo que su definición y especificaciones se pueden derivar de los metadatos disponibles en los sitios web (ibidem: 104 y ss.), lo cual muestra una semejanza con los indicadores de UNESCO.

Sirva como ejemplo que la CEPA está esperando el próximo estudio del EIGE ${ }^{80}$ con el fin de recoger datos y elaborar indicadores para el área relacionada con la presencia de mujeres en la esfera de la toma de decisiones de los medios de comunicación (CEPE 2014: 105). No obstante, se puede concluir exponiendo que el contenido de los índices de la CEPE no se corresponde con las herramientas utilizadas por UNESCO (Figura 2). El Proyecto de Monitoreo Global de Medios, por el contrario, es la iniciativa de incidencia pública más grande del mundo que evalúa como ha ido cambiando la representación del género en los medios, estudiando la representación de los hombres y las mujeres en las noticias desde hace 15 años $^{81}$, por lo que tiene más similitudes con los GSIM. En este sentido, uno de los objetivos básicos del GMMP es la realización de análisis diacrónicos, que permitan evaluar el mismo sistema mediático a lo largo del tiempo.

"La metodología del GMMP devino en modelo para realizar observación de medios desde una perspectiva de género en todo el mundo; también se adaptó para hacer observar el reporteo de temas desde una perspectiva de género. Cierta

${ }^{80}$ Se espera que el estudio del EIGE para diseñar los indicadores centrados en la participación y el acceso a la toma de decisiones en los medios de comunicación de las mujeres, con énfasis en: la presencia femenina en los órganos de toma de decisiones dentro de las empresas de medios de comunicación y la existencia de códigos de conducta y/o de otras formas de auto-regulación y el desarrollo de las empresas de medios de comunicación, para evitar la discriminación por razón de sexo.

${ }^{81}$ En noviembre de 2009 se realizó la cuarta muestra para el proyecto de 2009/2010, coincidiendo con Beijing +15 y la Cumbre para revisar los Objetivos de Desarrollo del Milenio. La red de miembros incluye grupos de género y comunicación, asociaciones de mujeres que trabajan para los medios y grupos de mujeres populares e investigadoras. 
capacitación para periodistas ha incorporado los resultados del GMMP, destacando la urgente necesidad de hacer un cambio hacia un periodismo con un mayor equilibrio de género y justicia de género" (GMMS, 2010: VI).

\section{FIGURA 3. INDICADORES COMUNES DE LAS TRES CATEGORÍAS DEL GMMS}

\section{Indicadores comunes a las tres categorías}

Tipo de medios Televisión, radio o diarios

Alcance de la Local, nacional, internacional, extranjero

historia

Tema central de la Celebridad, artes y deportes, social y

historia jurídico, crimen y violencia, ciencia y salud, economía, política y gobierno

Elaboración propia a partir de los datos del Proyecto Global de Monitoreo de los medios.

\section{Concepción teórico-conceptual}

Respecto a la concepción teórico-conceptual se puede afirmar que existen semejanzas entre los indicadores del GMMP y los de UNESCO, aunque ambos presentan algunas controversias que merecen ser evidenciadas. Entre las principales polémicas que se han observado al analizar las categorías de los indicadores y subíndices de los GSIM se pueden destacar tres: la occidentalización uniformada, la confusión entre el concepto de mujer y el de género y, por último, la escasa relación a las discriminaciones derivadas de las vinculaciones entre sexo, raza y clase (VERNUCCI y DE FRUTOS, 2014).

En primer lugar, el acceso a la información a través de los medios de comunicación se ve influenciado por diversos fenómenos, entre los que destaca el fenómeno denominado occidentalización uniformada ${ }^{82}$

\footnotetext{
${ }^{82}$ Término acuñado por el profesor José Vidal-Beneyto en su libro Derechos Humanos y diversidad cultural. Globalización de las culturas y de los derechos Humanos para hablar de la perspectiva occidental aplicada a distintos fenómenos
} 
o incluso etnocentrismo, una cuestión recurrente en la actualidad debido a la globalización y que lleva aparejado un proceso de uniformización cultural (MATTELART, ${ }^{83}$ 2014; VIDAL-BENEYTO, 2010). Este es uno de los principales problemas de los corpus de indicadores mediáticos y que se reproduce en los indicadores de género para medios de comunicación. En este conjunto de índices se utiliza una perspectiva eminentemente occidental que se materializa no solo de la aplicación de los indicadores sino de su propio enunciado, funcionando como un rodillo homogeneizador de las diferencias y las culturas que se pueden observar en los distintos entornos mediáticos. Esta debilidad del sistema de los GSIM se puede observar, por ejemplo, en la subcategoría B1.2. "Descripción equitativa de mujeres y hombres a través de la eliminación de estereotipos y promoción de la representación multidimensional" (UNESCO, 2012: 42). El enunciado refleja la preocupación por las distintas dimensiones de la representación mediática entendida como la capacidad de observar la diversidad entre hombres y mujeres, pero entiende la mujer como un sujeto universal. Es decir, la representación de la mujer blanca y rubia en televisiones de países donde la mayor parte de la población responde a otros rasgos raciales y étnicos puede simbolizar, de facto, una discriminación de una parte de la población femenina.

culturales, políticos y económicos que posteriormente es exportada y copiada en países no alineados, sobre todo de Europa del Este, Asia y América Latina. ${ }^{83}$ Armand Mattelart hizo referencia al etnocentrismo político que demanda una hegemonía económica en su discurso de investidura como Honoris Causa de la Universidad de Málaga el 28 de abril de 2014. El autor belga también hizo referencia al debate que explica la tensión entre economía y cultura mediante los procesos de internacionalización y mercantilización (MATTELART, 2014, 28 de abril). 
FIGURA 4. COMPARACIÓN ENTRE LOS GSIM (UNESCO 2012) Y LOS INDICADORES PROPUESTOS POR EL PROYECTO DE MONitoreo Global de MEdios
Indicadores de Género
Proyecto de Monitoreo Global
para Medios de
Comunicación de Medios Women's Media Foundation | 2010

\section{UNESCO | 2012}

Categoría A: Acciones para fomentar la igualdad de género en las organizaciones de medios de comunicación

A1 | Igualdad de género en el nivel de toma de decisiones

A2 | Igualdad de género en el Indicadores específicos de la trabajo y en las condiciones categoría 2 | Sujeto de las noticias. laborales

- Porcentaje de noticias presentadas en radio y televisión

- Porcentaje de noticias cubiertas por mujeres: Televisión, radio y diarios

- Porcentaje de mujeres como sujeto de la noticia de acuerdo con el sexo $\mathrm{del} / \mathrm{la}$ reportero/a

A3 | Igualdad de género en los sindicatos, las asociaciones y organizaciones de periodistas, otros profesionales de los medios de comunicación y organismos de autorregulación de los medios A4 Los medios de comunicación promueven códigos y políticas éticas a favor de la igualdad de género en el contenido de los medios de comunicación 
A5 | Igualdad de género en la educación y la formación

Categoría B: Representación del género en los contenidos mediáticos

B1 Representación del Indicadores específicos de la género en noticias y temas de categoría 1 | Sujeto de las noticias. actualidad

- Función en la historia: Opinión popular, experiencia personal, testigo ocular, sujeto, experto, portavoz

- Porcentaje de mujeres descritas como víctimas

- Porcentaje de mujeres identificadas por relación familiar

- Porcentaje de mujeres en fotografías de diarios

Indicadores específicos de la categoría 3 | Contenido de las noticias

- Porcentaje de noticias que cuestionaron los estereotipos de género

- Porcentaje de noticias que reforzaron estereotipos de género

- Porcentaje de noticias que destacaron la (des) igualdad de género

- Porcentaje de noticias que mencionaron políticas de igualdad de género o instrumentos jurídicos para los 
derechos humanos de las

mujeres

- Plataforma de Acción de Beijing:

Porcentaje de noticias que

destacaron: Pobreza, violencia de

género, paz, participación

económica de las mujeres y

participación política de las

mujeres

B2 | Representación de

género en la publicidad

\section{Elaboración propia}

La segunda cuestión tiene que ver con dos conceptos diferentes, aunque no opuestos, que son confundidos en los GSIM: el género y la mujer. Para UNESCO, género es sinónimo de mujer lo que presenta un grave error que se traduce en la representación de la realidad mediática que se realiza mediante los $\mathrm{GSIM}^{84}$. Si se considera el género como una de las maneras de dar sentido a las relaciones de poder, los estudios sobre la mujer pueden incluirse en los mismos, es decir, pueden ser vistos por medio de una perspectiva de género, lo que consiste en reconstruir la Historia de las mujeres por medio de dichas relaciones de poder. Al afirmar "los indicadores de género para medios de comunicación tratan de realizar una intersección entre

${ }^{84}$ Esta confusión no es solo propia de UNESCO sino que se reproduce en otros ámbitos que tienen que ver con los indicadores de género y los medios de comunicación. Por ejemplo, el artículo publicado por Christopher J. Ferguson (2012) sobre la imagen de la mujer, la sexualidade y la violencia o la investigación de Lindsey Meeks, de la Universidad de Washington, "He Wrote, She Wrote: Journalist Gender, Political Office, and Campaign News" (2013) publicado en Journalism and Mass Communication Quarterly sobre la relación entre el género de los periodistas y la cobertura mediática de los periódicos estadounidenses em las campañas electorales legislativas o ejecutivas. En ambos casos se trata el género como sinónimo de mujer. 
empoderamiento de las mujeres y el desarrollo de los medios" 85 (UNESCO, 2012: 15), se percibe que la utilización del género como un sinónimo de mujer. A lo largo del documento, por otra parte, también se enfatiza en el papel del hombre, reconociendo los derechos del padre y de la madre en el cuidado de los menores (UNESCO, 2012: 28).

Otro problema del documento de UNESCO se refiere a la utilización de género solamente para referirse a la relación hombre-mujer. Probablemente este fenómeno se deba a la confusión conceptual anteriormente citada, pero traza una problemática mucho más amplia que se concreta en la falta de reconocimiento de determinados grupos de individuos fuera de dicha lógica heterosexual normativa (BUTLER, 2009; VerA BALANZA, 2009a, 2004). En este sentido, el texto no reconoce palabras vinculadas a la diversidad afectivo-sexual, propias de los estudios de género como homosexual, transexual, transgénero, intersexual, etc. De hecho, la concepción del informe se refiere puramente a hombres y mujeres como se puede observar en la introducción:

"Gender equality and women's empowerment is one of the overarching priorities of UNESCO [...]. Equality as used here is meant to ensure that the potential of women/girls and men/boys is fully unleashed and that the value of each person is recognized without prejudice" ${ }^{\text {} 66}$ (UNESCO, 2012: 9).

Por todo ello, se concluye que el documento de UNESCO no representa la diversidad afectivo-sexual propia de todo estudio de género actual, realizando incluso una confusión terminológica entre

85 "Gender-Sensitive Indicators for Media seek to adress this intersection of women's empowerment and media development" (UNESCO, 2012: 15)

(Traducción propia).

86 “La igualdad de género y el empoderamiento de las mujeres es una de las prioridades de la UNESCO [...]. La igualdad como se usa en este documento tiene por objetivo garantizar que el potencial de las mujeres / niñas y hombres / niños está totalmente desarrollado y que el valor de cada persona es reconocida sin perjuicio" (UNESCO, 2012: 9) (Traducción propia). 
este concepto y la significación propia de los estudios de mujer. En tercer lugar, cuando se traza un corpus de indicadores específicos para el género, como sucede en el caso de los GSIM, se debe recoger la totalidad de las relaciones de dominación-explotación que se desarrolla en los distintos entornos mediáticos, lo que acaba desembocando en una interpretación individual y no social de un proceso que afecta a todas las estructuras de la sociedad ${ }^{87}$. Por tanto, la transformación debe albergar una categoría social representada por las mujeres y no por la idea de mujer individual, lo que dé lugar a políticas sociales eficientes y a la superación de todas las formas de explotación-dominación (SAFFIOTI, 2007).

Así, cuando el texto explica que "su foco principal [de los GSIM] está en la igualdad de género y las dimensiones de la diversidad social en los medios de comunicación" 88 (UNESCO, 2012: 15), se percibe que la cuestión de la clase social está reconocida pero no la cuestión de la raza y/o la etnia. De hecho, África fundamenta la segunda prioridad de UNESCO (junto con la igualdad de género) pero se considera una línea de acción independiente mientras que Saffioti (2007) considera que existe un nexo de unión indisociable entre género-raza/etnia y clase social.

FIGURA 5. RESPUESTAS DE LOS EXPERTOS QUE PARTICIPARON EN LA ELABORACIÓN DE LOS GSIM SOBRE LA PROBLEMÁTICA DE DICHOS INDICADORES

\section{Experto Respuesta \\ Experto Because it will provide a benchmark in terms of working 1 conditions and representation of women who are working in the media.}

\footnotetext{
${ }^{87}$ Llegados a este punto es muy interesante observar el trabajo de Zurbano Berenguer y Liberia Vaya (2014) sobre la comparación entre las definiciones legales y mediáticas de la violencia de género, que se propone como una reasignación de dicho problema social.

88 "Its [GSIM] main focus is on the equality and gender dimensions of social diversity in media" (UNESCO, 2012a: 15) (Traducción propia).
} 
As far as I have understood the main purpose of the GSIM is to enable media houses to evaluate their own

Experto

2

\section{Experto}

3 situation vis a vis gender balance among their professional staff (at various levels) and in their content. The idea is to encourage them to keep tabs on how they are doing in terms of achieving gender balance and motivate them to improve their own records. I'm an

The GSIM are meant for use by media decisions makers, media professionals and citizen advocates to characterize performance in gender equality in media content and

Experto

4 employment practices. To compare the situation in different countries would require a country level application of the GSIM. They may be too long and detailed for that use, but it would be interesting to try to apply them in that way to see if it works well for that purpose.

The development and the application of the indicators is definitely an important step because it allows generating data about gender issues. However, it does not as such

Experto resolve the problem of comparing situations in different 5 countries. The data collected on the basis of the GSIM would need to be subject to subsequent specific applications in order to contribute to an efficient comparing exercise.

Aunque no lo resuelve si resulta de gran utilidad al configurar una estrategia a través de la cual se pueden hacer aproximaciones cuantitativas, verificables y Experto comparables internacionalmente. Por supuesto, los 6 contextos nacionales son diferentes y ese hecho complejiza el proceso. No obstante, tener una herramienta como estas permite establecer tendencias, y sobre todo construir modelos más certeros de medición.

\section{Experto}

\section{7}

Elaboración propia 
Por tanto, los GSIM deberían considerar las discriminaciones que puede sufrir una mujer, ya sea profesional de los medios de comunicación o sujeto de alguno de sus contenidos, no solo por el hecho de ser mujer sino también por pertenecer a una raza o etnia determinada. En el caso de Brasil, por ejemplo, es fundamental la articulación entre género, raza/etnia y clase social puesto que es un país multirracial y la población negra representa, según los datos oficiales, el 51\% de la población (GOBIERNO FEDERAL DE BRASIL 2013), siendo el país con mayor número de esta población fuera de África.

Para concluir el análisis documental de los GSIM es necesario profundizar en el perfil de los expertos que elaboraron dicho documento. Un trabajo preliminar estudió dicha cuestión y los resultados evidenciaron que un $71,42 \%$ de los especialistas que participaron en el proceso fueron mujeres (DE FRUTOS, 2013). Es importante destacar que, si bien todos ellos poseían una experiencia previa en el campo de la comunicación, algunos de los informantes no poseían conocimientos específicos sobre estudios de género. Al preguntarles específicamente sobre la posible problemática de dichos indicadores de género para medios de comunicación los informantes adquieren una postura crítica (Figura 5).

A partir de la lectura crítica de los indicadores de género para medios de comunicación de UNESCO, mediante sus rasgos ideológicos, teórico-conceptuales y metodológicos, se han observado tres deficiencias principales. En primer lugar, existen evidencias de la existencia de una perspectiva basada en la occidentalización uniformada, que representa modelos claramente ligados a una esfera geopolítica determinada por la idiosincrasia de UNESCO, donde la mujer parte de un modelo muy definido. Además, esta situación empeora en los medios de comunicación privados, donde los estereotipos son utilizados frecuentemente y se observan modelos que no representan la mayor parte de la población de un entorno mediático determinado.

Esta característica de los GSIM también se reconoce en la segunda controversia, la ausencia nudo género-raza/etnia-clase social, puesto 
que las mujeres son vistas como sujetos universales en los medios de comunicación. Si bien utiliza el término en plural, no deja claro las intersecciones entre esos tres prismas, indisociables en el universo femenino en los medios de comunicación.

La última controversia observada en los indicadores tiene que ver con la confusión terminológica entre género y mujer, que se reconoce en el uso de estas dos palabras como sinónimos en numerables ocasiones a lo largo del informe. Del mismo modo, estos indicadores no permiten registran grupos de individuos fuera de la relación hombre y mujer (matriz heterosexual) (BUTLER, 2009).

Por todo ello, los indicadores de género para medios de comunicación de UNESCO demuestran preocupaciones contemporáneas importantes, pero también limitaciones claramente relacionadas con una visión universal de cuestiones culturales. En este sentido, puede ser interesante realizar una mejora utilizando la perspectiva de género en cuatro aspectos clave de las dinámicas mediáticas: la agenda de los medios de comunicación, las fuentes de información, el lenguaje y el enfoque de las informaciones.

En conclusión, se puede aseverar que existe una gran amalgama de indicadores que contemplan la relación entre género y medios de comunicación en la actualidad $\mathrm{y}$, previsiblemente, continuarán generándose iniciativas para la creación de nuevos instrumentos en este sentido. Tal es el caso de los Indicadores de Igualdad de Género de la CEPE que verán la luz a finales de 2014 y que en el momento de escribir estas páginas están aún en fase de borrador. Sin embargo, su análisis crítico ha permitido observar similitudes entre estas herramientas de evaluación del entorno mediático y las propuestas por Social Watch mediante el IEG o la Internacional Women's Media Foundation a través de los GMMP, discerniendo sobre dichas características mediante la descripción de sus rasgos ideológicos, teórico-conceptuales y metodológicos. 


\section{Concepción metodológica}

A nivel metodológico, el análisis crítico de los indicadores de género del GMMP tiene dos aspectos fundamentales. En primer lugar, el estudio recolecta datos cuantitativos, ofreciendo una imagen detallada del número de mujeres y hombres en el mundo de las noticias. Esta información se recopila a través de una guía diferente para prensa, radio y televisión. Los datos cualitativos son el segundo aspecto, con el que se consigue obtener un retrato completo de los contenidos en las noticias analizadas. Dado que el trabajo es voluntario y la formación de los participantes es diversa, la organización convocó siete talleres regionales de capacitación para trabajar en los indicadores que darían lugar a la investigación. Los indicadores utilizados en el estudio se pueden dividir en tres grandes categorías:

- Aquellos que tienen que ver con el sujeto de las noticias.

- Aquellos que tienen que ver con la mujer como profesional de la información, denominado en el informe "Reportando y presentando noticias".

- Aquellos que hacen referencia al contenido de las noticias.

Dentro de los GMMP $^{89}$ existen una serie de indicadores comunes (Figura 4) y otros específicos de cada categoría, que serán comparados con los indicadores de género para medios de comunicación de UNESCO en la Figura 3.

\section{Conclusiones}

La ausencia de literatura académica sobre los indicadores mediáticos en general y los índices de género y medios de comunicación en particular genera un desafío para cualquier aproximación a esta materia compleja y cambiante.

${ }^{89}$ Los indicadores de GMMP también hacen referencia al protagonista principal de la noticia. Así, se tratan como temas indicadores clave: la ocupación de los sujetos de la notica, la función de los sujetos de las noticias, las edades de los sujetos de las noticias, si son víctimas y sobrevivientes y la identidad y la familia. 
A partir de la lectura crítica de los indicadores de género para medios de comunicación de organizaciones públicas y sin ánimo de lucro UNESCO, Comisión Económica para Europa de Naciones Unidas, Social Watch y Women's Media Foundation-, se han podido ilustrar sus principales rasgos ideológicos, teórico-conceptuales y métodológicos, lo que ha permitido concluir que se siguen estructurando discursos dominantes mediante la utilización de estos instrumentos de medición.

Si bien las herramientas de medición pueden visibilizar situaciones de vulneración de derechos humanos ligadas al género de las personas que trabajan o aparecen en medios de comunicación, es necesaria una observación rigurosa de estos instrumentos de evaluación para observar cuál es su papel real dentro de estructuras de poder hegemónico. De no producirse dicho examen, estas herramientas, incluso con la perspectiva de género tenida en cuenta, generarán procesos etnocéntricos donde se perpetúen estereotipos ligados al sexo biológico, a la orientación afectivo-sexual y a la identidad de las personas.

\section{Referencias bibliográficas}

BUTLER, J. (2009). El género en disputa: El feminismo y la subversión de la identidad. Barcelona: Editorial Paidós.

CASTELls, M. y SuBIRATS, M. (2007), Mijeres y hombres, ¿un amor imposible? Madrid: Alianza Editorial.

COMISIÓN ECONÓMICA PARA EUROPA DE NACIONES UNIDAS (CEPE) (2014), Indicators of Gender Equality. Draft, 7 January 2014.

Consultado el 16 de febrero de 2014, http://www.unece.org/fileadmin/DAM/stats/documents/ece/ces/g e.30/2014/wshp/Consolidated_Gender_Report_3.2_for_CES_Co nsultation.pdf.

DíAZ NosTY, B. (2013b), "Ética, globalización y cultura democrática”. Conferencia celebrada en Ginebra dentro del programa del examen ministerial anual del Consejo Económico y Social (ECOSOC) el 5 de julio de 2013. 
Ferguson, C. (2012). "Positive Female Role-Models Eliminate Negative Effects of Sexually Violent Media", Journal of Communication, 62 (5), pp. 888-899.

Foucault, M. (1980), Microfísica del poder. Madrid: Ediciones de la Piqueta.

FreIRE, P. (2006), Extensão ou comunicação? Rio de Janeiro: Paz e Terra. GriZZLE, A. (2011), "Media and Information Literacy: The UNESCO Perspective in School 2.0. A Global Perspective", The Journal of Media Literacy, $\mathrm{n}^{\circ}$ 57, pp. 1-2.

INSTITUTO EUROPEO DE LA IGUALDAD DE GÉNERO (EIGE) (2012), Women and the Environment. Consultado el 14 de febrero de 2014, http:/ / eige.europa.eu/sites/default/ files/documents/Overview $\% 20$ o $\mathrm{f} \% 20 \mathrm{BPfA} \% 20-\% 20$ Women $\% 20$ and $\% 20$ the $\% 20$ Environment $\% 20$ $\% 20 \mathrm{~K}$.pdf.

INSTITUTO EUROPEO DE LA IGUALDAD DE GÉNERO (EIGE) (2013), Gender Equality Index Report. Vilnius: European Institute for Gender Equality. Consultado el 14 de febrero de 2014, http:/ / eige.europa.eu/content/document/gender-equality-indexreport.

INTERNATIONAL WOMEN'S MEDIA FOUNDATION (IWMF) (2011), Global Report on the Status of Women in the News Media. Consultado el 3 de febrero de 2012, http://www.iwmf.org/our-research/globalreport/.

Jorge Alonso, A. (2004), Mujeres en los medios, mujeres de los medios. Icaria: Madrid.

LOSCERTAles, F.; NuÑEZ, T.; Vera BALANZA, M. T.; GuARINOS, V.; GUERRERO SALAZAR, S. (2009b), "El perfil de las periodistas en Andalucía: formación y expectativas laborales. Un balance, 19892009" en LOSCERTALES, F.; NUÑEZ, T.; VERA BALANZA, M. T.; GUARINOS, V.; GUERRERO SALAZAR (Eds.), Las mujeres y los medios de comunicación: una mirada de veinte años (1989-2009). Sevilla: Instituto Andaluz de la Mujer, pp. 57-75.

MATTELART. M. (2014, 28 DE ABRIL), Discurso de investidura como Honoris Causa en la Universidad de Málaga el pasado 28 de abril de 2014. 
MATTELART, M. (1982), Mujeres e industrias culturales. Barcelona: Anagrama.

MATTELART, M. (1981), Mujeres e industrias culturales. Barcelona: Anagrama. Consultado el 29 de abril de 2014, http://unesdoc.unesco.org/images/0004/000484/048493sb.pdf. MEEKS, L. (2013), "He Wrote, She Wrote: Journalist Gender, Political Office, and Campaign News", Journalism and Mass Communication Quarterly, 90, pp. 58-74, Consultado el 15 de diciembre de 2013, http://jmq.sagepub.com/content/90/1/58.full.

NúÑEZ DOMÍNGUEZ, T. Y LOSCERTALES ABRIL, F. (Coords.) (2009), Las mujeres y los medios de Comunicación. Una mirada de veinte años (19892009). Sevilla: Instituto Andaluz de la Mujer.

ORGANIZACIÓN DE LAS NACIONES UNIDAS PARA LA EDUCACIÓN, LA CIENCIA Y LA CULTURA (UNESCO) (2012), Gender-Sensitive Indicators for media. Framework of Indicators to Gange Gender Sensitivy in Media Operations and content. Paris: UNESCO.

ORGANIZACIÓN DE LAS NACIONES UNIDAS PARA LA EDUCACIÓN, LA CIENCIA Y LA CULTURA (UNESCO) (2008a), Indicadores de Desarrollo Mediático: Marco para evaluar el desarrollo de los medios de comunicación social, Paris: UNESCO. Consultado el 2 de julio de 2012, http://unesdoc.UNESCO.org/images/0016/001631/163102S.pdf. ORGANIZACIÓN DE LAS NACIONES UNIDAS PARA LA EDUCACIÓN, LA Ciencia y la Cultura (UNESCO) (2008b), Plan de acción para la equidad entre géneros. Consultado el 15 de octubre de 2012, http://www.unhabitat.org/downloads/docs/7549_76082_GEAP_Sp anish.pdf.

PRograma de NACIONES UNIDAS PARA EL DESARROLLO (PNUD) (1990), Informe Sobre Desarrollo Humano, Bogotá: Panamericana Formas e Impresos.

Programa de NAciones Unidas PARA EL DESARrollo (PNUD) (2000), Objetivos del Milenio. Consultado el 3 de marzo de 2012, http://www.undp.org/content/undp/es/home/mdgoverview/. Programa de NACIONES UNIDAS PARA EL DESARROLLO (PNUD) (2006), Guide to Measuring the Impact to Right to Information Programmes. Oslo: United Nations Development Programme.

SAfFiotTi, H.I.B. (2007), Gênero, Patriarcado e Violência. São Paulo: Fundação Perseu Abramo. 
VERA BALANZA, M. T. y GUTIÉRREZ LOZANO, J. F. (2014), "Periodistas en transición. Expectativas sociolaborales y de género en los inicios de las emisiones de TVE en Andalucía" en GuILLAUMET, J. Y SALGADO, F. (Eds.), El periodismo en las transiciones politicas. De la revolución portuguesa y la transición española a la primavera árabe. Madrid: Biblioteca nueva, pp. 199-214.

VERNUCCI, L. y DE FRUTOS, R. A. (2014), “indicadores da UNESCO para mídia (GSIM): entre as políticas de gênero e as políticas de comunicação", Caderno Espaço Feminino, v. 27, n¹, Consultado el 8 de enero de 2014, http://www.seer.ufu.br/index.php/neguem/article/view/24725. VIDAL-BENEYTO. J. (Ed.), Derechos humanos y diversidad cultural. Globalización de las culturas y derechos humanos. Barcelona: Icaria Editorial. ZURBANO BERENGUER, B. Y LIBERIA VAYÁ, I. (2014), "Revisión teórico-conceptual de la violencia de género y de su representación en el discurso mediático. Una propuesta de resignificación “, Zer, 19 (36), pp. 121-143. Consultado el 11 de junio de 2014, http://www.ehu.es/zer/hemeroteca/pdfs/zer36-06-zur. 



\section{Violencia de Género y Medios de Comunicación José María Calleja}

\section{Introducción}

T OS medios de comunicación españoles no han encontrado aún 1 el relato adecuado para contar el terror que sufren las mujeres. En términos generales, los periódicos, las radios, los medios digitales $\mathrm{y}$, sobre todo, las televisiones, no han sido capaces aún de informar de la violencia de género de manera acorde con la gravedad de un problema que cada año cuesta la vida a más de cincuenta mujeres.

Desde 2004, en los últimos once años, en España, al menos 755 hombres asesinaron a 755 mujeres ${ }^{90}$. Sin embargo, no es habitual encontrar una frase construida así, tan expresiva y contundente, en un

\footnotetext{
${ }^{90}$ Para una información más detallada, véase el Portal estadístico https://www.msssi.gob.es/ssi/violenciaGenero/portalEstadistico/home.htm y el Informe sobre víctimas mortales por violencia de género, elaborado por el Ministerio de Sanidad, Servicios Sociales e Igualdad, en dic 2014. https://www.msssi.gob.es/ssi/violenciaGenero/portalEstadistico/docs/VMor tales_2014_cierre_2.pdf
} 
medio de comunicación; una frase que propicie que la población se percate de la importancia del problema. En buena parte de las noticias sobre violencia de género al hombre no se le nombra como 'asesino' y son habituales enunciados como 'un nuevo caso' o 'una mujer ha muerto' para describir un asesinato.

La violencia de género no está situada en la agenda informativa de la mayoría de los medios de comunicación españoles; los malos tratos y asesinatos de mujeres no se abordan de manera 'exhaustiva y proporcionada' acorde con la trascendencia que tiene el problema; como señalan Kovach y Rosenstiel (2003) que debería hacerse, al reclamar el necesario compromiso social del periodismo para tratar de forma adecuada las noticias. La trascendencia se explica no solo por las decenas de miles de mujeres que la sufren desde hace años, o por el número de víctimas mortales; no se trata sólo de un problema cuantitativo, su relevancia viene dada también porque el número de mujeres que sufren violencia de género nos habla de la falta de libertad de un importante sector de la población, invisible, que vive en el miedo; y de la desigualdad social que persiste entre mujeres y hombres. Estamos ante uno de los problemas más graves del país pese a que no se perciba así por la ciudadanía-, que los medios de comunicación no tratan con la importancia que debieran. No es un problema de las mujeres, es un problema de toda la sociedad.

En buena parte de los medios de comunicación, sobre todo en algunas televisiones, los asesinatos de mujeres se narran todavía como si fueran sucesos, o como si se tratara de casos aislados, vinculados exclusivamente a las características individuales y circunstancias particulares del que asesina y de la asesinada, como si fuera algo privado que solo a ellos dos atañe. Además, no todos los asesinatos de mujeres a manos de su pareja o ex pareja son tratados como violencia de género.

El hecho de que recientemente los medios de comunicación, junto a cada asesinato, den el dato de si la mujer había denunciado a su asesino, no sabemos hasta qué punto no insinúa cierta responsabilidad de la víctima, si no ha denunciado, en su propia tragedia. El asunto es que la denuncia no es siempre la solución, 
sobre todo si los recursos y apoyos a posteriori son insuficientes. Es preciso explicar, para entender, que el miedo que sufren las mujeres amenazadas puede tener un efecto paralizante. No todas las mujeres que viven en un clima de violencia se atreven a denunciar a la persona con quien conviven, y es frecuente que se bloqueen. Muchas mujeres sufren en silencio y soledad, a veces con sus hijos como únicos testigos, sin arriesgarse a contarlo ni a amigas ni a familiares. No siempre es fácil dar el paso de denunciar al maltratador.

Sabemos también de mujeres que deciden que no soportan más la situación, que creen que deben separarse, y que cuando anuncian a su pareja que no quieren vivir más con él, son asesinadas. Aunque resulte paradójico, los asesinatos de mujeres dan información también de la lucha cotidiana de las mujeres por su independencia y su libertad, una libertad que no soportan ni aceptan sus acosadores.

Los medios de comunicación deberíamos preguntarnos a qué responde el hecho de que cada semana haya una mujer asesinada por un hombre que ha compartido la vida con ella. Una sucesión de crímenes que hablan de un problema estructural: la violencia que ejercen algunos hombres sobre las que consideran 'mujeres de su propiedad'. Hablamos de un problema cultural, de una asignación de roles en una sociedad androcéntrica, en la que los asesinatos de mujeres son una de las primeras causas de muerte violenta en España.

\section{Los marcos cognitivos y las palabras}

La manera en que informamos sobre la violencia contra las mujeres también tiene que ver con lo que George Lakoff, en su libro No pienses en un elefante. Lenguaje y debate político (2007), llamaba 'marcos'. Los marcos de referencia, que conforman lo que Lakoff denomina 'inconsciente cognitivo', son estructuras mentales, adquiridas y asumidas por el sentir común, que orientan nuestro modo de ver el mundo, de entenderlo y de reaccionar.

Conocemos los marcos a través del lenguaje, pues todas las palabras se definen en relación a marcos conceptuales. Cuando los humanos oímos una palabra, se activa en nuestro cerebro un marco, o una 
colección de marcos. La forma en que la sociedad percibe la violencia de género tiene que ver también con esos marcos, con tradiciones, roles asignados para cada sexo, estereotipos y hábitos aceptados. De ahí que cambiar de marcos implique cambiar el modo que tiene la gente de entender el mundo. Puesto que el lenguaje activa los marcos, los nuevos marcos requerirán un nuevo lenguaje. Podemos decir que la manera en la que se informa de la violencia de género tiene que ver con un marco cognitivo forjado históricamente, sedimentado por generaciones, según el cual la mujer es un ser inferior, supeditado y secundario respecto del hombre protagonista.

'La mujer, la pata quebrada y en casa', se decía y se escribía en España hasta no hace mucho tiempo. 'Mi marido me pega lo normal', es el título de un libro de Miguel Lorente (2003) que recoge una frase textual pronunciada por algunas mujeres en el pasado reciente, que asumían como algo 'normal' el hecho de que sus maridos les pegaran. Muchos hombres entendían que pegar a la mujer era lo propio y adecuado, porque existe un marco construido e interiorizado que, si no se cambia, justifica y perpetúa la dependencia y la desigualdad entre unas y otros, verdadera causa de la violencia de género.

Como sostiene el filólogo alemán Victor Klemperer (2001: 31), "las palabras pueden actuar como dosis ínfimas de arsénico: uno las traga sin darse cuenta, parecen no surtir efecto alguno, y al cabo de un tiempo se produce el efecto tóxico". Veamos algunas de las palabras/perífrasis empleadas para referirse al asesinato de una mujer a manos de aquél con quien mantenía o mantuvo una relación, e indaguemos cuál puede ser su efecto tóxico.

'Crimen pasional' Eran las palabras que se empleaban de manera sistemática durante la dictadura franquista para informar en los periódicos -siempre en las páginas de sucesos- del asesinato de una mujer a manos de su pareja. Nunca se escribía que un hombre había asesinado a una mujer sin ligarlo a un motivo 'pasional'.

Lejos de haber desaparecido, esta expresión la emplean aún hoy algunos medios de comunicación para 'justificar', en la medida en la 
que se apela a una causa, el asesinato de una mujer a manos de su pareja o ex pareja.

Sirva el ejemplo del artículo "¿Quién cree aún a Pistorius?", publicado en El País (3/3/2014), cuya entradilla anuncia que "Comienza el proceso contra el deportista sudafricano, acusado de asesinar a balazos a su novia”. En el cuerpo textual, puede leerse:

“(...) ¿Qué estaba pasando por la cabeza del célebre atleta -'el hombre más veloz del mundo sin piernas'- cuando disparó cuatro balas a través de la puerta cerrada del baño de su casa, tres de las cuales acabaron con la vida de Reeva Steenkamp? ¿Supo perfectamente quién estaba detrás de la puerta, como pretenderá demostrar el fiscal? ¿Fue un crimen pasional? ¿O es verdad la versión de Pistorius, que mantiene que creyó haber estado disparando a un intruso, que actuó convencido de que se estaba protegiendo a sí mismo y a la mujer que amaba?”

'Compañero sentimental'. Durante muchos años, en los medios de comunicación - no así en la vida- ha sido frecuente el uso de la expresión 'compañero sentimental' para referirse al hombre que asesinaba a una mujer con la que mantenía una relación sin estar casado. Es una expresión propia del pasado que refuerza el estatus diferente de quienes que no han santificado su unión con el vínculo del matrimonio. Ese término trasnochado -inadecuado también por la falsedad literal que conlleva- todavía hoy se utiliza.

Véanse algunos ejemplos de titulares y entradillas de noticias recientes, en los que también se destaca en negrita el uso de otros términos inadecuados que se citan en este artículo: "El compañero sentimental de la rumana asesinada en San Mamés se declara autor", es el titular del Diario de León, cuya entradilla informa de que "La víctima, Daniela Chicu, que apareció asfixiada en su domicilio el pasado 4 de septiembre, tenía dos hijos de muy corta edad" (Diario de León, 23/6/2014) 
Otro artículo titula: "Asesinada otra mujer a manos de su compañero sentimental en Utrera" (Libertad Digital, 16/2/2014), y en el cuerpo textual añadía:

"Una mujer de 18 años ha muerto esta madrugada en la localidad sevillana de Utrera tras ser apuñalada por su compañero sentimental, que a continuación se dio a la fuga y que fue detenido horas después. El suceso se produjo de madrugada en la barriada de El Tinte. Cuando la Policía llegó al lugar de los hechos tras recibir el aviso de un vecino, el agresor ya había huido mientras que la víctima permanecía inconsciente. Fue trasladada al centro de Salud, donde ingresó cadáver."

'Violencia doméstica'. Es otra de las expresiones que, durante años, se ha empleado para referirse al asesinato de una mujer a manos de un hombre. La expresión representa un avance respecto a 'crimen pasional', puesto que ya no se justifica al maltratador ni se busca la excusa en 'lo mucho que la quería', como ocurría antes; sin embargo, no refleja la dimensión del problema, puesto que restringe la explicación al ámbito particular y privado, y no acusa como criminal a quien ejerce el maltrato.

La expresión 'violencia doméstica' hace referencia a todo tipo de agresiones que se producen en el hogar, domus; pero, en sentido amplio, lo que sucede en el ámbito doméstico afecta no solo a las mujeres, también a sus hijos o, incluso, a los abuelos que conviven en la misma casa. La palabra 'doméstica' relativiza la tremenda carga del maltrato, humillación, miedo o asesinato de una mujer a manos de un hombre. Se diría que algo 'doméstico' es una cuestión menor, de andar por casa, que no tiene por qué tener repercusión en el espacio público. Normalmente, hablamos de 'accidente doméstico' cuando éste no tiene consecuencias graves, cuando el daño es menor al producido por un accidente de tráfico o laboral, por ejemplo. Su uso, para referirse a la violencia ejercida contra las mujeres, es equiparable a otros términos como 'violencia familiar' o 'intrafamiliar'. No son expresiones que sirvan para contar el problema social que representa la violencia contra las mujeres a manos de sus parejas o ex parejas. 
Sin embargo, todavía hoy su uso es frecuente, como se advierte en los ejemplos siguientes.

Así, con el titular: "Una pareja muerta en un pueblo de Lugo en un nuevo caso de violencia doméstica" (El Heraldo.es, 25/4/2014); en el cuerpo textual se destaca que "Los fallecimientos se produjeron con un arma para disparar bengalas que pudo modificar el marido". Hay que señalar que no es lo mismo hablar de 'asesinato' que de 'fallecimiento' y 'pareja muerta', donde, además, se pone en el mismo nivel a asesinada y asesino.

Con el titular "Octavo caso de violencia doméstica en Madrid en 2013" (La Razón, 28/9/2013), el cuerpo textual insiste en hablar de "muerte de la mujer", en vez de considerar el hecho un asesinato:

“(...) el consejero madrileño de Asuntos Sociales, Jesús Fermosel, ha lamentado la muerte de la mujer -de origen ecuatoriano y nacionalidad española- y ha mostrado su preocupación por el estado de su hijo, quien se encuentra hospitalizado dado que sufrió dos heridas craneales con un arma blanca."

'Violencia de género'. Se ha empleado de manera reiterada desde los años noventa para definir la violencia contra las mujeres a manos de sus parejas o ex parejas, y se ha consagrado su uso sobre todo a raíz de la aparición de la Ley Orgánica 1/2004 de Medidas de Protección Integral contra la Violencia de Género.

Se han suscitado diferentes polémicas a propósito del término 'género' por la coincidencia de la palabra, y la equiparación que ha querido hacerse con el género gramatical, masculino o femenino. Así, hay quienes han querido entender que, puesto que hay dos géneros gramaticales, el hablar de violencia de género incluiría también, aunque sea excepcional, la que una mujer puede ejercer contra un hombre. Sin embargo, hablar de 'género' -frente al sexo biológico- y de 'violencia de género' implica reconocer que existe una construcción cultural en la que a cada uno de los sexos se le han adjudicado y consolidado determinados roles y estereotipos que, 
históricamente, se han naturalizando e incorporado al imaginario colectivo; implica reconocer que la violencia contra las mujeres es un problema estructural, la más extrema manifestación de la desigualdad social entre mujeres y hombres.

Cuando se habla de 'violencia de género' se entiende que 'las violencias' que se ejecutan contra las mujeres por aquellos hombres con quienes han mantenido vínculos de dependencia, son consecuencia del intento de conservar su poder sobre ellas, que esa violencia que ejercen tiene su origen en la situación de subordinación, inferioridad y discriminación que, durante siglos, se ha instaurado en un mundo dominado por varones, donde algunos siguen considerando a las mujeres como 'objetos de su propiedad'; de ahí la pervivencia de frases como "la maté porque era mía", o "es mía, o no es de nadie". En este sentido, esta terminología conlleva la explicación de la violencia se ejerce contra las mujeres por el hecho de serlo.

'Violencia de género' parte de la evidencia de que son los hombres los que matan a sus esposas, novias o ex parejas y que, en muchos casos, las asesinan cuando sienten que ya no serán 'suyas', cuando ellas les anuncian que los quieren dejar, que se quieren divorciar, que quieren ser libres, cuando son capaces de romper la relación de sumisión y dejar de vivir bajo el mismo techo, cuando se niegan a tener más relaciones -sexuales, de convivencia o de coexistencia- con ellos.

También es cierto y evidente que, aunque haya muchos casos de violencia de género, los hombres, por el hecho de serlo, y aunque muchos hayan asumido actitudes y comportamientos machistas, no son potenciales maltratadores o asesinos de mujeres.

'Violencia machista'. Ha sido la última expresión en incorporarse y la han adoptado diferentes medios para referirse a la violencia de género, y evitar la polémica suscitada con el 'género'. Quienes la utilizan destacan el hecho de ser los varones quienes la ejercen; algo que, para algunos, no logra aclarar en español el término 'violencia de género'. Toda violencia de género es una violencia machista, que responde a una visión del mundo sexista. Es una violencia que se 
sustenta en un mundo desigual en el que las mujeres y 'lo femenino' se ha visto supeditado y subordinado al dominio privilegiado masculino.

Esta expresión alude, pues, directamente, a la forma de pensar, sentir y al comportamiento de los varones que la ejercen. Hablar de violencia machista conlleva denunciar esa visión del mundo, y remite a la causa fundamental de la violencia de género: la desigualdad y asimetría en las relaciones. Violencia machista aporta matices distintos respecto de violencia de género y sitúa a determinado pensamiento como germen de los asesinatos y los malos tratos a las mujeres.

Sin embargo, en los medios de comunicación, en lo que se refiere a aludir a 'violencia de género' y 'violencia machista', es más fácil que se plasme esa interpretación -que alude a la desigualdad social y al patriarcado instaurado para buscar explicaciones-, en algunos artículos de opinión escritos por periodistas comprometidas en este tema, antes que por cualquier noticia sobre un nuevo asesinato. ${ }^{91}$

'Terror contra las mujeres'. No es un sintagma consagrado por el uso frecuente, pero refleja de manera gráfica la situación en la que vive una mujer sometida a la tortura del maltrato, del desprecio, de la humillación, de los golpes y amenazas, que son las bases sobre la que se sustenta el asesinato.

Es difícil encontrar una palabra que refleje en toda su inmensa gravedad la situación de las mujeres que comparten su vida con alguien que las desprecia, las humilla, las insulta y les pega sistemáticamente, día tras día. Esta expresión se centra, más que en las causas, en la vivencia y consecuencias de quienes están inmersas en un clima de violencia. 'Terror contra las mujeres' sirve para definir la tortura continuada y describir el miedo cotidiano que las víctimas

${ }^{91}$ Véanse, a propósito, los siguientes artículos: Violencia de género y sociedad (Margarita María Pintos. El País. Opinión. 27/6/2009) y Violencia machista, violencia patriarcal (Beatriz Gimeno, Eldiario.es, 27/5/2013) 
soportan en silencio, sin capacidad muchas veces de reaccionar y sublevarse contra esa agresiva humillación. Terror contra las mujeres sirve para relatar cómo antes del asesinato de una mujer ésta ha sufrido un proceso continuo de cosificación, de anulación de su personalidad, de allanamiento de su voluntad, de maceración en un clima de miedo, generado precisamente por el hombre con quien convive.

\section{La construcción del asesinato de género en los medios de comunicación}

Es frecuente ver en algunos periódicos cómo la noticia de una mujer asesinada aparece en la misma sección en la que se habla de la detención de unos atracadores, acompañada de una foto que muestra los objetos robados. Podemos ver en una televisión cómo se narra el asesinato de una mujer en clave de suceso, o cómo se cuenta con un estilo sensacionalista.

En demasiadas ocasiones observamos también cómo se ofrece un espectáculo antes que una información adecuadamente contextualizada. Se tiende a dar detalles del asesinato, irrelevantes desde el punto de vista informativo, que no hablan de la gravedad del asunto. La noticia se interpreta y se centra en los detalles escabrosos, de más impacto, que distorsionan la información, con el fin de añadir morbo para captar la atención del espectador y ganar audiencia. Algunas televisiones suelen emitir imágenes de la mujer asesinada en el lugar del crimen -si hay sangre, mejor aún-y, en demasiadas ocasiones, no se respeta la imagen de la víctima.

Como si un serial al que se va añadiendo morbo, el periódico El Mundo (29/11/2013), en la sección de Sucesos, va describiendo el asesinato en Cifuentes (Guadalajara) de una mujer, Carolina Calderón, a manos de su marido carnicero: "Enterró el tronco y llevó la cabeza y las extremidades a las rehalas de las cacerías", se señala en el titular; y son varios los datos escabrosos que se incluyen en la entradilla: "El asesino de la mujer embarazada echó a los perros los restos de la víctima"; "Ha confesado que la descuartizó en las dependencias de la 
carnicería que regentaba", "La víctima estaba embarazada de siete meses y tenía otros tres hijos".

Y sigue el relato en el cuerpo textual:

“(...) (el asesino) ha confesado haber echado las extremidades y la cabeza de la víctima para que se las comieran los perros, mientras que el tronco lo enterró tras una nave de su propiedad.

$(\ldots)$

El viernes 25, la Guardia Civil halló el tronco de la víctima enterrado tras una nave próxima a la localidad de Cifuentes y aún mantiene un dispositivo para buscar el resto del cuerpo.”

Sobre la misma noticia, y en la misma fecha, el diario 20Minutos (29/11/2013) añade: “(...) tras matar a Carolina de un golpe en la cabeza, troceó el cadáver y echó las extremidades y la cabeza para que las comieran los perros de las rehalas del pueblo"

Y el periódico La Vanguardia (29/11/2013), se recrea en más datos aún:

“(...) el presunto autor de este crimen llevó en bolsas los restos del cuerpo de su pareja a las rehalas de las cacerías que se llevan a cabo en el pueblo para que se los comieran los perros.

(...) Hasta el momento, los Cuerpos y Fuerzas de Seguridad del Estado solamente han hallado restos de esta mujer, de origen colombiano y que estaba en avanzado estado de gestación"

La información convertida en espectáculo banaliza el mal y deriva en morbo ¿Qué sentido tienen determinadas imágenes de archivo? ${ }^{92}$. Mientras se recrean datos irrelevantes, falta la explicación pertinente,

\footnotetext{
${ }^{2}$ Sobre esta noticia, el informativo de Castilla-La Mancha TV en su edición de noche abrió la información con las imágenes de carne picada para ilustrar el descuartizamiento de la mujer por su marido carnicero. La polémica se divulgo en la mayoría de los medios de comunicación escritos.
} 
la interpretación adecuada de un hecho grave que no puede ser tratado como un suceso, como un hecho aislado ni como un espectáculo.

La violencia de género tampoco es una 'lacra', como a veces se describe, puesto que no es una secuela o señal de una enfermedad o achaque. La violencia de género, los asesinatos de mujeres a manos de hombres con los que mantienen un vínculo, los malos tratos, amenazas y desprecios, deben explicarse como la consecuencia de una estructura social y cultural, sustentada en los cimientos del patriarcado, que ha promovido y 'naturalizado' la desigualdad entre los sexos. La violencia de género existe porque, como señala Amelia Valcárcel (2008), la agenda de la paridad está aún pendiente; y conseguir esta agenda posibilitará el que las mujeres sean y se sientan libres.

Todavía hoy para informar de un asesinato de violencia de género encontramos frases del tipo 'un nuevo caso de violencia' para encabezar la noticia, lo que supone una forma reiterativa, deshumanizada, sumarial, de abordar la tragedia.

En la sección de Sucesos, con el titular "Cinco mujeres muertas en lo que va de año" (El Mundo. Sucesos. 21/2/2009), se introduce la noticia con el antetítulo: "Dos nuevos casos de violencia doméstica tiñen las cifras de 2009.” En el cuerpo textual se insiste:

"Pocas horas después, otra mujer fue encontrada muerta en su casa de Rociana del Condado (Huelva) tras haber sido estrangulada.

El suceso ocurrió tras una discusión "que fue subiendo de tono" hasta que, en un momento dado, el hombre apuñaló a la mujer, según informa la Jefatura de Policía.

Junto al cuerpo de la fallecida, en la cocina de la vivienda, la policía encontró el cuchillo con el que se ha producido la agresión." 
Decir 'caso' es poner el asesinato de la mujer en un plano de suceso, detectivesco, de novela negra; supone incluirlo dentro de una contabilidad deshumanizada y ajena. Encabezar la información con 'otro caso más', 'un nuevo caso' no humaniza a la víctima ni culpabiliza al asesino. Cuando -como se observa en el ejemplo anterior- hay datos suficientes para dar una explicación de violencia de género, los medios deberían comprometerse y utilizar un lenguaje apropiado que facilite al lector entender la dimensión de un problema atroz y arraigado: es preciso hablar de 'mujer asesinada' y no de "otra mujer encontrada muerta" y de 'fallecida'; es preciso culpabilizar a 'el hombre' e insistir en que era su marido; y recordar que ese 'suceso' se repite aproximadamente 70 veces a lo largo de un año.

Hay decenas de testimonios de mujeres víctimas de violencia de género, en todos los países, de todas las clases sociales, de todos los niveles culturales; carentes de estudios y con alta cualificación. Entre quienes sufren la violencia de género hay juezas, abogadas, médicas, psicólogas y profesoras de universidad. Por eso, si no es relevante, no es necesario destacar determinados datos de la víctima (cuando es pobre, extranjera, prostituta...) que reducen en el imaginario colectivo la violencia contra las mujeres a casos marginales, como si no se ejerciera en contextos que se perciben como 'normales' por una mayoría de la población. Destacar la 'marginalidad' de quien sufre la violencia de género, o el hecho de ser inmigrante, hace que buena parte de la sociedad la advierta distante, lo que no favorece que la población comprenda la magnitud y cercanía del problema.

De la misma forma, habría que criticar el enfoque de algunas informaciones. Por ejemplo, la de un padre que, en Tomares, intenta asesinar a su mujer y a su hija, y en la que se titula con aparente asombro: 'Era una familia completamente normalizada' ( $A B C$. Sevilla, 9/11/2013):

"«Era una familia completamente normalizada», ha afirmado la concejal de Bienestar Social, Igualdad y Familia del Ayuntamiento de Tomares, Maite Garay. (...) Vivían en Fuente de Aljamar, una urbanización cerrada, y nunca habían vivido una situación así. 'No estaban separados, era una familia 
normal: unos padres y una hija'. Llevaban varios años viviendo en Tomares y la pequeña incluso había estudiado en el colegio Al-Ándalus algunos cursos."

Se nos explica en la información lo que es 'una familia normalizada': aquella compuesta por padre, madre e hijos -se nos dice- como subrayando lo insólito de que en una familia de esas características el padre haya intentado asesinar a la madre. Contado así, pudiera parecer que los hechos que se relatan serían más 'lógicos' en una familia que no fuera 'completamente normalizada'; una familia con padres divorciados, quizás, o sin hijos. Los asesinatos y la violencia contra las mujeres a manos de hombres con los que mantienen o han mantenido un vínculo, se producen en todo tipo de familias, en todo tipo de niveles sociales, culturales o económicos.

En abundantes informaciones, como se ha advertido ya en las noticias previas, el titular destaca que 'una mujer ha muerto' y en el cuerpo de la noticia se alude a 'la fallecida'. En contados medios se mantiene en la noticia el hecho tajante de que 'una mujer ha sido asesinada'. Y es casi imposible encontrar una construcción de la frase que diga: 'un hombre ha asesinado a una mujer, lo que eleva a (...) las mujeres asesinadas por hombres en lo que va de año'. O bien, 'lo que eleva a (...) los hombres que han asesinado a mujeres en lo que va de año'. No suele tenerse claro quién es el sujeto en estos crímenes, a diferencia de otras informaciones de asesinos y víctimas, en las que no hay dudas al respecto.

No hay, desde luego, en muchas de las informaciones que hablan de mujeres asesinadas una posición beligerante del narrador a favor de la víctima, que sí existe, por ejemplo, cuando se informa de otro tipo de delitos: terroristas, crímenes o asesinatos de menores o adolescentes.

Se pueden leer, aún hoy, detalles accesorios que describen a la mujer asesinada: 'era joven', 'atractiva' e 'iba muy maquillada'; o bien, se destaca en el titular el que era prostituta. Como si el hecho de serlo debiera penalizar menos el crimen. Véase el ejemplo de El Periódico (10/03/2010): "La mujer asesinada en el Eixample era una prostituta 
de lujo rusa" (Titular); "Los Mossos hallaron el lunes el cuerpo en la cama y con la cabeza destrozada"(Entradilla). En el cuerpo textual:

“(...) Era rusa y tenía 30 años. Los vecinos destacan su belleza y gusto por la buena ropa. Nunca había causado un altercado ni se le recuerdan problemas. Sin embargo, murió de forma trágica. (...)

'Era tan guapa y tan elegante que al principio no pensé que trabajara en eso, que fuera prostituta', explica un vecino"

En el asesinato del Salobral se habla de una adolescente 'muy desarrollada'; se dice o se sugiere que 'era gótica' y "vestía de negro', o que 'tenía más edad real de la oficial'. Se subraya que la diferencia de años entre el criminal y la mujer asesinada es considerable. Es completamente irrelevante el apelar a la imagen de la mujer asesinada y a determinados detalles que orientan a culpabilizarla. Con ciertas descripciones, parece que se quisiera hurgar en encontrar causas y motivos que justifiquen o expliquen la actuación del maltratador o el asesino. Del mismo modo, también en las televisiones, a propósito del crimen de El Salobral se refuerza la 'turbulenta historia de amor' y que 'él había perdido la cabeza por ella'. Se argumenta, pues, el que se trata de 'un asesinato pasional', de un 'crimen pasional', como si el amor o la 'locura de amor' aminoraran la responsabilidad del asesino (Antena 3, 22/10/2012):

"Una turbulenta historia de amor detrás de los crímenes de El Salobral.

Almudena ha sido una de las víctimas del asesino del Salobral. Tenía 13 años y mantenía una relación con el que a la postre sería su asesino, Juan Carlos Alfaro Aparicio, de 39 años.

Según ha podido saber Espejo Público, detrás de los crímenes de la pedanía albaceteña de El Salobral, se esconde una turbia historia de amor. La joven Almudena tenía dos perfiles en Facebook, uno con su nombre real y otro con el significativo nombre de 'Oscuridad'. (...) Juan Carlos, un experto cazador y 
de formación militar, pues fue miembro de los Cuerpos de Operaciones Especiales, también tenía su perfil en la red social aunque era menos activo que ella. (...)

La madre del asesino confeso ha declarado que su hijo estaba 'deprimido' y aseguraba que 'había perdido la cabeza' ante la imposibilidad de poder ver a la niña. Además ha asegurado en declaraciones al diario El Mundo, que las relaciones entre su hijo y Almudena eran consentidas."

Con todo ello, además de sugerirse una justificación, se privatiza el problema al volver a hablarse de las características particulares del asesino y de la asesinada, de las diferencias de edad entre el criminal y la víctima, de las peculiaridades de cada uno como explicativas del hecho. Se rebaja la dimensión de la tragedia y su impacto público, y se relega la explicación de violencia machista para ser tratado como un asunto propio entre dos personas, que afecta a una pareja concreta.

La idea de 'algo habrá hecho' la mujer para ser agredida o asesinada por el hombre está vigente aún en algunos sectores de la sociedad española. La idea de que el conflicto lo crea la mujer sigue vigente, no solo entre los hombres. El marido de Marta Anguita, la apuñaló hasta dieciséis veces. En el documental La maleta de Marta (2013) ${ }^{93}$, cuenta que cuando su madre fue a visitarla al hospital donde se recuperaba, sus primeras palabras fueron: 'QQué escandalazo has armado!'. La mujer víctima del hecho, es vista como culpable por su propia madre.

En la sociedad, pues, y en la narración de algunos medios, se mantiene esa nefasta idea de que 'algo habrá hecho' la mujer para que

${ }^{93}$ Documental coproducido por TVE, dirigido por Günter Schwaiger, estrenado en Madrid en septiembre de 2013. Presentación: http://www.rtve.es/alacarta/videos/dias-de-cine/dias-cine-maletamarta/2024378/

Hasta diciembre de 2014 pudo verse completo en www.rtve.es > Televisión > La 2) El documental. 
su marido le haya pegado, maltratado o acuchillado. Una asunción también de la violencia como algo 'natural', que ha existido siempre, que no es necesariamente malo y que se debe aceptar sin rebelarse.

Algunas veces se cuenta de la mujer asesinada que se había separado del asesino, que ahora tenía una nueva pareja, que 'había rehecho su vida' o que salía con sus amigas, como si esto la hiciera sospechosa o en parte culpable de su propia muerte.

Se dice también en muchas ocasiones que la mujer no había denunciado previamente malos tratos, como si eso la hiciera casi cómplice de su propio asesinato por omisión de denuncia y exonerara de culpa al victimario. El hecho cierto es que la denuncia de los malos tratos no garantiza la protección: también hay mujeres asesinadas y que sufren maltrato que han interpuesto denuncias; por eso, habría que preguntarse hasta qué punto el señalar si se ha denunciado es un dato relevante que ha de destacarse en el titular, cuando se está informando de que una mujer ha sido asesinada.

En el relato informativo de algunos medios, además de buscar argumentos y explicaciones en el comportamiento de la víctima, existe una tendencia a exculpar o entender al victimario $y$, en no pocos casos, se adopta una posición equidistante entre el hombre asesino y la mujer asesinada. Ese tratamiento es pernicioso y deplorable. El periodismo ha de elaborar un relato basado en la empatía con las mujeres que son víctimas de la violencia de género, sin recurrir a un tono compasivo y paternalista.

\section{E1 contexto exculpatorio en la violencia de género}

Es incomprensible que en las noticias se relate un contexto que, lejos de explicar a qué responde la violencia contra las mujeres, tienda a buscar argumentos para entender la actuación del asesino. Así, son habituales las informaciones en las que se dice que el asesino -pocas veces nombrado con la palabra 'asesino'- 'había bebido', o 'estaba deprimido', o 'quería con locura' a la mujer que mató; se insiste en que la mujer le había anunciado que quería separarse y eso le había enfurecido. Con esta manera de enfocar la información parece que se 
intenta explicar, cuando no justificar, la reacción del criminal. Esos detalles tienden a eximir al asesino por estar 'deprimido', 'alcoholizado', 'en paro', despechado bajo el efecto del anuncio de que su mujer quería ser libre y abandonarlo.

El criminal, en algunos casos, parece producir una cierta fascinación que impregna la narrativa de algunos medios. Se habla, por ejemplo, de las destrezas del asesino en el manejo de las armas, 'cazador y buen tirador' (caso Salobral), o de su inteligencia (caso Bretón); o, en el caso del falso monje Shaolín, se llama al criminal que asesinó a una mujer 'maestro', 'monje', 'campeón de kung-fu', sin contrastar ninguna de estas informaciones -apreciaciones que luego resultan ser falsas, pero que ya han quedado fijadas como ciertas en el impacto de las primeras informaciones-, mientras que a sus víctimas se las califica de inmediato de 'prostitutas' o 'inmigrantes subsaharianas', como una forma de criminalizarlas.

Hay, pues, en las informaciones una especie de comprensión hacia la reacción violenta del asesino, un contexto a veces exculpatorio o, como mínimo, comprensivo respecto del criminal, al que parece que se pretende entender en su actuación violenta; un hecho reforzado, sutilmente, cuando se dan determinados datos accesorios de la víctima, como la forma de vestir, la diferencia de edad - 'era más joven que él'-, sus gustos musicales o estéticos, el tipo de fotos que tenía en Facebook o las fotos que exhibía en Twitter.

En ocasiones, el propio periódico, con un testimonio ocasional y subjetivo, exculpa en el titular al asesino: "El hombre no es consciente de lo ocurrido". Y sigue exculpándose en el texto: "Muere una anciana que estaba en coma tras ser agredida por su marido en un hospital cacereño. (...) El marido, que no había mostrado nunca actitudes violentas, no es consciente de lo sucedido." (El Mundo, 12/12/2004). Ocurre también que, a veces, se ponen en un mismo plano, en tratamiento y tiempo, los testimonios del asesino y los de las víctimas o sus familiares, cuando no son testimonios equiparables. 


\section{La jerarquización de testimonios y opiniones}

Los medios tienden a ofrecer testimonios de gente que está en el lugar del crimen, o que son vecinos, o conocidos, o que pasaban por allí en el momento en que se grababan las imágenes, sin un criterio de selección por su relevancia, interés o porque aporten información. Así, se recogen testimonios que se emiten por la facilidad para captarlos y en no pocos casos se ofrece un altavoz a alguien que parece estar más interesado en salir en televisión para hablar de sí mismo, que en explicar lo ocurrido.

En la noticia: "Se investiga un caso de violencia doméstica en Lugo" (El Heraldo.es, 25/4/2014), con el ladillo “Consternación”, se añade:

“(...) el alcalde de Foz, Jorge Javier Castiñeira, ha manifestado que los vecinos del municipio están "consternados". El regidor focense ha dicho que no se podía "imaginar" que pasara esto a "esta familia", que "pudiese llevar al asesinato de una mujer y el posterior suicidio del marido". (...)

Sobre el presunto homicida que acabó suicidándose, ha dicho el alcalde que era 'una persona muy seria y muy educada', aunque ha precisado que 'en los últimos años pasaba por un periodo de depresión importante y hace un año se abortó un intento de suicidio'. 'No sé qué pudo pasársele por la cabeza', ha sentenciado."

La información del terror contra las mujeres víctimas de violencia de género no puede hacerse con el criterio de rellenar una pieza informativa con lo primero que venga a mano. El periodista norteamericano, ex director del Washington Post, Ben Dradlee (2000:481), sostiene que "la mancha originada por la prensa amarilla se ha ido expandiendo con la ayuda de la televisión, transformándose en lo que podemos llamar 'periodismo de queroseno'. En este tipo de periodismo los periodistas echan queroseno en el primer sitio que ven humo, antes de determinar qué es lo que lo produce y por qué". 
No todos los testimonios sirven; se deben seleccionar y jerarquizar por la información que aporten, por la autoridad de quien opina y porque ayuden a entender el problema.

\section{La televisión en el relato de la violencia de género}

La televisión como creadora de realidad constituye la principal, y a veces única, fuente de información para millones de personas. Frente a los textos escritos, que pueden dar lugar a debate o duda por el lector, la imagen en televisión resulta incontestable. Como señala Acaso, "depositamos un enorme grado de confianza en las representaciones visuales" (2007: 15). Las imágenes que salen en televisión no se discuten, se dan por verdad; verdad absoluta y sin asomo de duda. El tratamiento que se da a las mujeres en las televisiones y la manera en la que se informa de los asesinatos machistas son de gran importancia para configurar la percepción de los espectadores con la violencia de género.

Puesto que damos por cierto que existe aquello que vemos en imágenes y nos creemos lo que muestra la televisión, construimos nuestra idea del mundo con aquello que sale en pantalla. Las imágenes tienen un inmenso poder a la hora de configurar nuestro concepto de verdad. Para millones de ciudadanos en todo el mundo, la imagen que tienen de la realidad que les rodea, del mundo en el que viven, se gesta a través de las imágenes que les ofrece el televisor.

Teniendo en cuenta que la media de consumo televisivo está en torno a las cuatro horas por persona y día, según los datos del EGM (Estudio General de Medios), ${ }^{94}$ podemos augurar la enorme influencia y

\footnotetext{
${ }^{94}$ Según los datos del EGM (Estudio General de Medios) que vieron la luz en 2014, en el informe Marco General de los Medios en España 2014, la media de consumo televisivo por persona y día en 2013 fue de 246 minutos; es decir, 4 horas y 26 minutos. En el último informe del EGM, divulgado por la AIMC (Asociación para la investigación de los Medios de Comunicación) EGM: Resumen General de febrero a noviembre 2014, se establece el consumo de televisión en 238 minutos por persona y día. Se puede acceder a los informes a través de la web: www.aimc.es
} 
la gran importancia que tiene el cómo se traten los asuntos en este medio masivo que, como se ha dicho, para muchos espectadores constituye la única forma de estar conectados con el mundo.

La representación de la violencia machista no se configura solo desde los espacios informativos. Hay determinados programas, considerados de entretenimiento, cuya base se sustenta en los conflictos interpersonales, que han hecho de los insultos, los desprecios, la falta de respeto a la intimidad y los gritos, su razón de ser y su lenguaje. Estos programas también contribuyen a construir, a través de los casos que tratan y de cómo los abordan, un imaginario sobre la violencia. Willy Pasini (1994) afirmaba que los programas violentos garantizan elevados índices de audiencia; y las televisiones, en muchas ocasiones, renuncian a su compromiso ético para convertir la violencia en un espectáculo, lo que parece que proporciona beneficios empresariales.

El Ministerio de Igualdad, en uno de sus análisis sobre la aplicación de la Ley de Violencia de género decía que:

"La cultura mediática sigue hipotecada por la persistencia de contenidos que legitiman la violencia de género y que se conforma, por ejemplo, en los culebrones o en los llamados talk show, como un elemento cultural decisivo en torno al sexismo, la instrumentalización del cuerpo de la mujer y la violencia implícita y explícita de género en las relaciones de pareja" ${ }^{\text {95 }}$

Frivolizar con la violencia que sufren las mujeres, mercadear con los sentimientos o usar su cuerpo como objeto de reclamo en programas de televisión, publicidad o informativos, construye el humus que acaba propiciando la violencia que sí mata, la que acaba asesinando a las mujeres.

\footnotetext{
${ }^{95} \mathrm{http}$ ://www.mujeresenigualdad.com/El-show-televisivo-de-la-violencia-degenero_es $3 \_1 \_652 \_242 . h t m l$
} 
Diferentes estudios ${ }^{96}$ denuncian la infrarrepresentación de las mujeres en los medios de comunicación. Así, señalan que su presencia ni es equitativa respecto a la presencia de hombres, ni representa su participación social real; con lo cual se invisibiliza a las mujeres de la vida pública. El Informe elaborado por el CAC (2013) también denuncia que, cuando aparecen, la representación de las mujeres en televisión es inadecuada, tanto en los informativos como en los programas de entretenimiento ${ }^{97}$. La televisión refuerza los viejos mitos de la sociedad patriarcal que están unidos a 'lo femenino'; pueblan los espacios de mujeres-objeto, mujeres-víctimas, mujeresdependientes, a quienes se les niega cualquier capacidad en el campo del conocimiento. En la pantalla las mujeres aparecen como sujetos activos de chismorreos; programas de televisión, pensados sobre todo para mujeres, donde el público femenino asiste en directo; programas que insisten en reproducir viejos tópicos. Estas imágenes sobre las mujeres y su papel en el mundo resultan decisivas para mantener los anacrónicos estereotipos entre los millones de espectadores que consumen televisión.

Como Pierre Bourdieu señaló en La dominación masculina (2000), los valores androcéntricos, que perpetúan la subordinación y la violencia contra las mujeres, se mantienen y reproducen no solo a través de la violencia explícita sino también a través de mecanismos implícitos y sutiles, que llevan a Bourdieu a acuñar el término de 'violencia simbólica'. Esta violencia simbólica se ejerce muy a menudo desde la televisión, en la medida que presenta a la mujer como un ser inferior, a quien caricaturiza y considera como histérica, cotilla o necia. Su

\footnotetext{
${ }^{96}$ Uno de los más recientes ha sido el Informe realizado por el CAC (Consejo Audiovisual de Cataluña), que maneja datos de 2013. Para un resumen de los datos, véase el artículo de Dolors Comas "La representación de las mujeres en los medios de comunicación”, publicado en Eldiario.es, el 6/11/2013 http://www.eldiario.es/agendapublica/impacto social/representacionmujeres-medios-comunicacion 0 193880948.html

${ }^{97}$ A propósito del tema, resulta muy interesante el Documental de Documentos TV-Miss Escaparate. http://www.rtve.es/alacarta/videos/documentostv/documentos-tv-miss-escaparate/1714695/
} 
imagen denigrante e infravalorada es nefasta para construir una sociedad paritaria.

En el tratamiento de la violencia de género por parte de algunos medios de comunicación, especialmente en la televisión, vemos cómo la violencia ha invadido el campo informativo, se ha convertido en un espectáculo y ha sido muchas veces banalizada y descontextualizada; convertida en agente de entretenimiento, provocador de emociones y elemento atractivo de primer orden para captar audiencias.

El periodismo debe comprometerse en denunciar lo que sucede con las explicaciones oportunas y en elaborar un relato que favorezca una sociedad más libre y más justa.

\section{Referencias bibliográficas}

Acaso, M. (2006). Esto no son las Torres Gemelas. Cómo aprender a leer la televisión y otras imágenes. Madrid: Editorial Catarata.

AIMS.Asociación para la investigación de los Medios de Comunicación. (2014). Marco General de los Medios en España. 2014 EGM: Resumen General de febrero a noviembre 2014. Se puede acceder a los informes a través de la web: www.aimc.es

Bourdieu, P. (2000). La dominación Masculina. Barcelona: Editorial Anagrama.

Bradlee, B. (2000). La vida de un periodista. Madrid: Ediciones El País. Calleja, J. M. (2006).Algo habrá hecho. Odio, muerte y miedo en Euskadi. Madrid: Editorial Espasa.

Calleja, J.M. (2013). La violencia como noticia. Madrid: Ediciones Catarata.

Calleja, J.M. (2014). Informar sobre la violencia de género. Guía de buenas prácticas para los medios de comunicación. Zaragoza: Prensas Universitarias de la Universidad de Zaragoza. 
Documentos TV. Miss Escaparate. En:

https://www.youtube.com/watch?v $=7 \mathrm{wgSCTjJ} 4 \mathrm{qw}$

Kapuscinski, Ryszard. (2005). Los cinco sentidos del periodista. Estar, ver, oir, compartir, pensar. Madrid: Colección Nuevo Periodismo. Asociación de la Prensa de Madrid.

Klemperer, V. (2001). LTI La lengua del Tercer Reich. Apuntes de un filólogo". Barcelona: Editorial Minúscula.

Kovach, B. y Rosenstiel, T. (2003). Los elementos del Periodismo. Madrid: Ediciones EL PAÍS.

Lakoff, G. (2007). No pienses en un elefante. Lenguaje y debate politico.

Madrid: Editorial Complutense.

Lorente, M. (2003). Mi marido me pega lo normal. Agresión a la mujer: realidades y mitos. Barcelona: Editorial Crítica.

Ministerio de Sanidad, Servicios Sociales e Igualdad. (2014) Portal estadístico.https://www.msssi.gob.es/ssi/violenciaGenero/portalEstad istico/home.htm.

Ministerio de Sanidad, Servicios Sociales e Igualdad (2014). Informe sobre víctimas mortales por violencia de género:

https://www.msssi.gob.es/ssi/violenciaGenero/portalEstadistico/do cs/VMortales 2014 cierre 2.pdf

Ortega, F. (2011). La Política Mediatizada. Madrid: Editorial Alianza.

Pasini, W. (1994). Querer y no quererse. Barcelona: Seix-Barral

Scwaiger, G. (2013). Documental La maleta de Marta. En:

http://www.rtve.es/alacarta/videos/el-documental/documentalmaleta-marta/2168287/

Valbuena de la Fuente, F. (1997). Teoría General de la Información.

Madrid: Editorial Noesis.

Valcárcel, A. (2008), Feminismo en el mundo global, Madrid: Cátedra

Vicente Serrano, P. (2002) "La representación de la mujer y de lo femenino en la nueva publicidad", en Interculturalismo y mujer. Huesca: Editorial del Instituto de Estudios Altoaragoneses. 


\title{
1 \\ La violencia machista: Conceptos e implicaciones psicosociales
}

\author{
Trinidad Núñez Domínguez \\ Universidad de Sevilla \\ Perfil de Google ${ }^{98}$ y número orcid ${ }^{99}$
}

\section{Violencia y agresividad: conceptos y procedimientos}

— L TÉRMINO agresividad procede del latín 'aggredi', que significa ir en contra de alguien. Así pues, agredir es atacar, destruir o hacer daño. Debemos incluir otra acepción del término que tiene un matiz aparentemente constructivo al entenderse como sinónimo de 'espíritu emprendedor'. Es un concepto tan relacionado con lo cotidiano que tiene ese peligro parejo de parecer impreciso. En el Handbook of Social Psychology de 1998 se encuentra definida la agresión o la violencia como cualquier conducta dirigida a hacer daño a la integridad física, los bienes o la estima de una persona. Es decir, implica la aceptación de que existe intencionalidad. Puede observarse que desde este planteamiento se

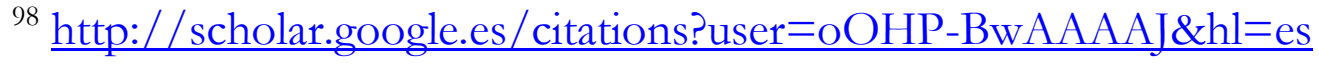

${ }^{99}$ http:// orcid.org/0000-0002-1576-7402
} 
consideran como términos sinónimos violencia y agresión. Conviene decir, sin embargo, que existen matices. Por ese motivo ya comenzábamos subrayando que estamos ante conceptos resbaladizos. Resulta gráfica y clara la definición que hace Guerrero Muñoz (2008: 18) reconociendo que se puede entender "la violencia como el revestimiento cultural de la agresividad".

La violencia, en sus diferentes variantes (física, psicológica, estructural o simbólica), forma parte de la vida en comunidad y la propia sociedad, por ese motivo, ha establecido un sistema legal que permita intervenir para explicar sus matices y penalizar sus consecuencias. Puede hablarse de delito, de agresión, de transgresión, de asesinato o de desorden. Cualquiera de estas categorías aluden a la construcción social de la violencia; por lo tanto, éstas definen y catalogan el fenómeno violento.

A principios del siglo XX se unió el concepto agresividad con una disposición temperamental innata. Esa asociación no está exenta de lógica; sin embargo, posteriormente se ha podido argumentar que la influencia del temperamento en la conducta agresiva del ser humano es moderada y está condicionada por factores psicosociales además de los biológicos. Ciertamente la agresividad está delimitada por reacciones psicofisiológicas, motoras. "La violencia no es mecánica sino dinámica" (Guerrero Muñoz, 2008: 19). Desde el conductismo social, especialmente con las aportaciones de Bandura (1982), se ha valorado la importancia de la imitación y del aprendizaje vicario en la adquisición de pautas agresivas. Junto a la agresividad hacia afuera o extrapunitiva se puede dar una agresividad hacia dentro $O$ intropunitiva, haciéndose daño la propia persona a sí misma. En este capítulo vamos a centrarnos en el primer caso. López Zafra (2007) recuerda que pueden diferenciarse dos tipos de agresión: a) la afectiva o colérica y b) la instrumental. La primera es reactiva. Se produciría porque hay una provocación previa y el fin es dañar a alguien. En la segunda el fin no es hacer daño (en el sentido estricto de la palabra) sino conseguir un objetivo, por ejemplo, conseguir poder. 


\subsection{Factores psicosociales de la agresividad y la violencia}

Algunas teorías sitúan a la agresividad como "un instinto básico" del ser humano, como "un patrón innato que compartimos con otras especies, incluida la forma en que los humanos expresamos las emociones" (Hogg \& Vaughan, 2010: 444). De hecho Lorenz (1966) ya describió cómo los animales responden agresivamente ante una situación de amenaza. No obstante, esta afirmación requiere de ser matizada y por ese motivo describiremos, aunque sea de manera somera, los factores que se encuentran implicados: desde los personales a los ambientales o los culturales.

\subsubsection{Factores personales}

Existen rasgos individuales que son comunes entre personas que se muestran violentas: la baja tolerancia a la frustración o el narcisismo son alguna de ellos. Igualmente se reconoce que las personas con personalidad de tipo A pueden ser más agresivas hacia otros si perciben que compiten contra ellos en una misma tarea importante (Hogg y Vaughan, 2010 citando a Carver y Glass, 1978). Una personalidad de tipo A se caracteriza por la impaciencia, por el espíritu competitivo o por la hostilidad manifiesta.

Fueron Dollard y colegas los que ya en 1939 unieron frustración a la agresión. La hipótesis frustración-agresión está muy claramente explicada por Arias (2007: 422) afirmando que se trata de "cualquier estímulo o acontecimiento que obstaculiza o bloquea la consecución de una meta genera frustración y, a su vez, la frustración desencadena irremediablemente una reacción agresiva". Según esto, la frustración precede a la agresión y la frustración tiene como consecuencia la agresión. Investigaciones posteriores a la de Dollard consideraron demasiado simplista la teoría y apuntaban que la adecuada definición del término 'frustración' incidía también en los problemas de solidez de dicha hipótesis. Se defendió que aunque la frustración podía conducir a la agresión, no siempre la precedía. Podían darse otros comportamientos: huida, llanto... Así pues se concluye que la frustración puede ser un estímulo dominante (eso sî) para la agresión. 
Por su parte, el narcisismo es un rasgo de la personalidad que se caracteriza por un exacerbado egocentrismo, extrema preocupación por sí mismo, sobreestimación y un sentido de grandiosidad. Esa mirada extrema de uno mismo puede llevar a extremar las relaciones con los demás. El 'deseo del otro' como objeto de deseo se convierte en una estimulación perversa del comportamiento final.

\subsubsection{Factores ambientales}

Arias (2007) plantea, al menos, tres causas ambientales que "justificarían" la agresividad humana: a) El ruido; b) El hacinamiento, c) La temperatura y d) El dolor.

Al referirse al ruido aclara que no se trata tanto de que un nivel elevado de decibelios provoca una acción agresiva sino que lo que la produce es la incapacidad para predecirla o para controlarla. Respecto del hacinamiento, tampoco se trata de una cuestión cuantitativa sino cualitativa. Se habla, entonces, de la experiencia subjetiva displacentera asociada a la densidad " $\mathrm{n}$ ' de personas/espacio". Por su parte, se entiende como Teoría de la ley térmica de la delincuencia aquella que determina que a medida que sube la temperatura ambiental también aumenta la agresión. Ciertamente la relación temperaturaagresión no es lineal. Existen estudios que avalan que en países fríos, la agresividad es menor. Interesante es conocer que no se produce más agresividad en los países extremadamente cálidos sino en aquellos que tienen climas cálidos (Van de Vliert y otros, 1999). También el dolor puede constituirse en un potente antecedente de la agresión aunque, de nuevo, los estudios resaltan la percepción subjetiva del individuo ante el hecho y no el hecho en sí mismo como productor.

\subsubsection{Factores culturales}

Las conclusiones de un estudio planteado por Tolan y Gorman-Smith (2002) se resumen en que las tasas de homicidios y violencia no letal fueron más altas en varones jóvenes de grupos minoritarios de sectores urbanos marginales. Estos datos, junto a otras investigaciones relevantes, permiten afirmar a Hogg \& Vaughan 
(2010) que los grupos en desventaja social son más vulnerables a la práctica de acciones violentas. Así, es posible referirse a factores micro-culturales y macroculturales.

En este contexto se plantea el concepto de privación relativa, que se define como la sensación de tener menos de lo que sentimos que merecemos. La privación relativa es un sentimiento de descontento asociado con la idea de que hay muy pocas posibilidades de mejorar la situación. Si no se puede progresar de forma legítima, una persona marginal puede agredir, robar o cometer actos vandálicos (Hogg y Vaughan 2010, 466). Habría que añadir que el sentimiento de una persona en esta situación es: “total, ¿qué se pierde?”. Alineado con esto, existen subculturas (tribus urbanas determinadas) donde la violencia está legitimada como forma habitual de relacionarse. Es más, quien no se adhiere a esa forma de comportarse, puede recibir sanciones o la expulsión del grupo de referencia y pertenencia. A nivel macro podemos señalar las diferencias entre culturas. No todas las culturas entienden la agresión y la violencia como algo indefendible.

La mezcla de historia, política, religión y filosofía, determinan posiciones. Debe recordarse que todavía existen sociedades donde se mercadea con las mujeres obligándolas a casarse con quien las compra. La cultura occidental, en concreto, incluye como un valor que se trasmite, la no violencia y la defensa legal de los derechos humanos. Sin embargo, nuestra sociedad no está exenta de vivir una violencia soterrada, semi-invisible y más que políticamente incorrecta.

\section{Manifestaciones de la agresividad: La violencia contra las mujeres}

\subsection{De la legislación a las formas y manifestaciones}

La violencia contra las mujeres es una manifestación de desigualdad de género y deja patente la existencia que un grupo social (de hombres) domina y maneja el poder en su sentido más peyorativo, y un grupo social (de mujeres) es dominado o subordinado. Sin necesidad de ir muy atrás en el tiempo, pueden encontrarse datos tan 
elocuentes como los que, referidos al Estado español, se reseñan a continuación:

- En 1944 estaba prohibida la entrada en la Bolsa a perros y mujeres.

- Hasta 1961, las mujeres que se casaban eran despedidas de sus empresas. Pero, a la vez, la situación ideal de una mujer era la de casada. Por lo tanto, a las mujeres se les pedía (exigía) que estuvieran casadas y trabajando en la casa, pero no saliendo al mundo público, que era 'cosa de hombres'.

- Hasta 1967 estaba prohibido en España que las mujeres pudieran ser juezas. De hecho, la primera mujer que entró en la judicatura fue en 1977.

- Entre finales de los sesenta y mediados de los años setenta, las mujeres necesitaban autorización expresa de su marido o su padre para firmar un contrato laboral o ejercer el comercio. Y no podía pedir un crédito bancario aunque tuvieran nómina si no iban acompañadas de un hombre (padre o marido).

- Hasta el 2 de mayo de 1975, el Código Civil español hablaba de la obediencia que la mujer debía al marido.

La Constitución de 1978 incorpora en su artículo 15 el derecho de todas las personas a la vida y a la integridad física y moral, sin que en ningún caso puedan ser sometidas a torturas ni a penas o tratos inhumanos o degradantes. Estos derechos vinculan a todos los poderes públicos y sólo por ley puede regularse su ejercicio. A pesar de ello, los primeros datos estadísticos sobre la violencia en el ámbito familiar aparecen en España en el año 1984, cuando el Ministerio del Interior saca a la luz pública el número de denuncias presentadas en las Comisarías de la Policía: aparecen como "denuncias por malos tratos".

En 1993 la Asamblea General de las Naciones Unidas aprobó la Declaración sobre la eliminación de la violencia contra la mujer (Resolución de la Asamblea General 48/104 del 20 de diciembre de 1993), en la que se definió como: 
"Todo acto de violencia basado en el género que tiene como resultado posible o real un daño físico, sexual o psicológico, incluidas las amenazas, la coerción o la prohibición arbitraria de la libertad, ya sea que ocurra en la vía pública o en la vía privada."

En 1996, la Organización Mundial de la Salud (OMS) declara que la violencia es un problema de Salud Pública, destacando las tremendas repercusiones sociales que específicamente crea la violencia contra las mujeres. El 17 de diciembre de 1999, por medio de la resolución 54/134, la Asamblea General de las Naciones Unidas, declara el 25 de noviembre como 'Día Internacional de la Eliminación de la Violencia contra la Mujer'. Esta resolución fue aprobada por 60 gobiernos como punto de partida para acabar con la lacra de los malos tratos. La fecha se elige por corresponder al aniversario del brutal asesinato de las hermanas Mirabal (Patria, Minerva y María Teresa), símbolos muy destacados de la resistencia contra la dictadura del General Trujillo (dictador de la República Dominicana), que fueron asesinadas el 25 de noviembre de 1960 por miembros de la policía secreta cuando volvían de visitar a sus maridos encarcelados. Sus cadáveres destrozados aparecieron en el fondo de un precipicio. Para el movimiento popular y feminista de la República Dominicana históricamente estas mujeres han simbolizado la lucha y la resistencia. $\mathrm{Y}$, desde la aprobación de esta resolución, para el resto de países.

En el territorio nacional se perciben cambios a principios de la década de los noventa, cuando empiezan a usarse los términos 'violencia familiar', 'violencia intrafamiliar' y 'violencia doméstica'. Debe recordarse que el Código Penal de 1995 no recoge estos términos ni se convierten en objeto de estudio en la formación académica de las Facultades de Derecho del territorio español. Pero el caso 'Ana Orantes' rompe esa dinámica de tal manera que la violencia contra las mujeres se convierte en tema de agenda para los medios de comunicación a partir de diciembre de 1997 y hace de revulsivo social y jurídico.

Merecen especial atención dos Leyes Orgánicas que promueven la prevención y la protección de las mujeres. Nos referimos a: 
A. Ley Orgánica 1/2004, de 28 de Diciembre, de Medidas de Protección Integral Contra la Violencia de Género

B. Ley Orgánica 13/2007, de 26 de noviembre, de Medidas de Prevención y Protección Integral contra la Violencia de Género.

La primera Ley mencionada se aprueba el 22 de diciembre de 2004 y entra en vigor en enero de 2005. Nos parece interesantísimo (imprescindible) leer la exposición de motivos. Textualmente nos dice:

"La violencia de género no es un problema que afecte al ámbito privado. Al contrario, se manifiesta como el símbolo más brutal de la desigualdad existente en nuestra sociedad. Se trata de una violencia que se dirige sobre las mujeres por el hecho mismo de serlo, por ser consideradas, por sus agresores, carentes de los derechos mínimos de libertad, respeto y capacidad de decisión.”

La Organización de Naciones Unidas en la IV Conferencia Mundial de 1995 reconoció ya que la violencia contra las mujeres es un obstáculo para lograr los objetivos de igualdad, desarrollo y paz y viola y menoscaba el disfrute de los derechos humanos y las libertades fundamentales. Además la define ampliamente como una manifestación de las relaciones de poder históricamente desiguales entre mujeres y hombres. Existe ya incluso una definición técnica del 'síndrome de la mujer maltratada' que consiste en las agresiones sufridas por la mujer como consecuencia de los condicionantes socioculturales que actúan sobre el género masculino y femenino, situándola en una posición de subordinación al hombre y manifestadas en los tres ámbitos básicos de relación de la persona: maltrato en el seno de las relaciones de pareja, agresión sexual en la vida social y acoso en el medio laboral. En la realidad española, las agresiones sobre las mujeres tienen una especial incidencia, existiendo hoy una mayor conciencia que en épocas anteriores sobre ésta, gracias, en buena medida, al esfuerzo realizado por las organizaciones de mujeres en su lucha contra todas las formas de violencia de género. Ya no es un delito invisible, sino que produce un rechazo colectivo y una evidente alarma social. 
La segunda Ley establece en su artículo 3 el concepto de violencia de género, entendiendo como tal aquella que, como manifestación de la discriminación, la situación de desigualdad y las relaciones de poder de los hombres sobre las mujeres, se ejerce sobre estas por el mero hecho de serlo. Comprende cualquier acto de violencia basada en género que tenga como consecuencia, o que tenga posibilidades de tener como consecuencia, perjuicio o sufrimiento de la salud física, sexual o psicológica de la mujer, incluyendo amenazas de dichos actos, coerción o privaciones arbitrarias de su libertad, tanto si se producen en la vida pública como privada. Según Naciones Unidas, las formas y manifestaciones de la violencia contra la mujer son las siguientes:

A. Violencia contra la mujer dentro de la familia:

- En la pareja: violencia física, psicológica, sexual y económica.

- Prácticas tradicionales nocivas: infanticidio, ablación o mutilación genital, preferencia por hijos varones, matrimonio precoz y/o forzado, exigencia de la dote, crímenes por honor, prácticas nocivas con mujeres de edad avanzada o viudas.

B. Violencia contra la mujer en la comunidad:

- Feminicidio.

- Violencia sexual infringida fuera de la pareja.

- Acoso sexual y violencia en el lugar de trabajo, en las instituciones educativas y en los deportes.

- Trata de mujeres.

C. Violencia contra la mujer cometida o tolerada por el 
Estado (a través de agentes o políticas públicas):

- Privación de libertad.

- Esterilización forzada.

D. Violencia contra la mujer en conflictos armados:

- Violencia física, psicológica o sexual.

E. Violencia contra la mujer y discriminación múltiple:

- Factores como: raza, origen étnico, casta, clase, condición migrante o refugiada, edad, religión, orientación sexual, estado civil, discapacidad, condición de VIH, etc.

La violencia de género, por lo tanto, no es sólo la que se ejerce contra la mujer por su pareja en el entorno del hogar; es mucho más amplia, afecta a mujeres de todo el mundo y adquiere, en cualquiera de los casos, formas atroces. La Organización Mundial de la Salud en $2002^{100}$ alerta que la violencia de género es la primera causa de pérdida de años de vida entre las mujeres de 15 a 44 años; por encima de las guerras, de los accidentes de tráfico o del cáncer.

\subsection{De la violación a las relaciones violentas}

Sin embargo, aunque contar con legislación ha supuesto un paso de gran trascendencia, todavía hay mucho que reivindicar y por lo que trabajar. De hecho, el 3 de marzo de 2010, Amnistía Internacional

\footnotetext{
100 Informe mundial sobre la violencia y la salud que publica en español la Organización Panamericana de la Salud
} 
publica un artículo titulado "La violencia contra las mujeres sigue siendo invisible en la Unión Europea"101, con el que hace una llamada de atención a la Presidencia Española de la Unión para que trabaje en profundidad sobre este tema. Se ofrecen datos alarmantes, como que en Suecia sólo el $12 \%$ de las violaciones denunciadas a la policía desemboca en juicio; que en Dinamarca el sexo sin consentimiento con una persona en estado de indefensión no está definido como violación en el Código Penal, sino como abuso sexual, y no es punible dentro del matrimonio; que en Francia una mujer muere cada tres días a manos de su pareja y que en España las víctimas de violencia de género en situación irregular se enfrentan a la amenaza de expulsión si se deciden a denunciar. Aunque pone énfasis en otros países donde considera que se desconoce la magnitud del problema, ya que la violencia de género en los países de la Unión Europea sigue estando oculta. Sería en los casos de Eslovenia, Finlandia, Grecia, Holanda, Hungría, Lituania, Polonia y Rumania, porque en ellos no existen registros de información sobre violencia de género ni en las comisarías, ni en los juzgados. Pone énfasis en países como Austria, Bulgaria, Estonia, Italia o Malta, porque ellos ni siquiera tienen legislación o planes de acción para abordar la violencia.

El número de mujeres asesinadas por sus parejas o ex parejas no disminuye. La Agencia Europea de Derechos Humanos (FRA) ha realizado una macroencuesta sobre violencia contra las mujeres a nivel europeo. Este estudio responde a una petición de datos sobre este tema, realizada por el Parlamento Europeo, con el fin de tomar medidas para la erradicación de la violencia contra las mujeres en la Unión Europea (UE). En este estudio se han realizado entrevistas personales a 42.000 mujeres en los 28 Estados miembros de la Unión, con una media de 1.500 entrevistas por país. La selección de las encuestadas se hizo por muestreo aleatorio. Los resultados son representativos de las experiencias y las opiniones de mujeres con

${ }^{101}$ El Gabinete de prensa de la sección española de Amnistía Internacional facilita estos datos en su página:

https://www.es.amnesty.org/noticias/noticias/articulo/la-violencia-contra-lasmujeres-sigue-siendo-invisible-en-la-union-europea/ . Recuperado (enero 2015) 
edades entre los 18 y los 74 años y residentes en este marco europeo. Las entrevistas del estudio comprendían preguntas sobre violencia física, sexual y psicológica, victimización durante la infancia, hostigamiento y acoso sexual, incluyendo nuevos medios para cometer abusos, como Internet. Se solicitó a las encuestadas que facilitaran información sobre su experiencia personal de diversas formas de violencia, la frecuencia con la que habían sufrido ciertos tipos de violencia y las consecuencias que la esta había tenido en sus vidas. La encuesta recopiló también información sobre la presentación o no de denuncia a la policía, y sobre el uso por parte de las mujeres de otros servicios que ofrecen asistencia a las víctimas.

Los resultados son los siguientes ${ }^{102}$ :

- Trece millones de mujeres en la Unión Europea experimentaron violencia física durante los 12 meses previos a la entrevista de la encuesta. Esa cifra equivale a un $7 \%$ de mujeres con edades de entre 18-74 años.

- Se calcula que 3,7 millones de mujeres experimentaron violencia sexual durante los 12 meses previos a las entrevistas de la encuesta. Esta cifra equivale a un $2 \%$ de mujeres con edades de entre 18-74 años.

- Una de cada veinte mujeres (5\%) ha sido violada desde los 15 años de edad. Esta cifra está basada en las respuestas ofrecidas a la siguiente pregunta de la entrevista: "Desde los 15 años de edad hasta ahora, ¿con qué frecuencia le han obligado a mantener relaciones sexuales mientras la sujetaban o le hacían daño de alguna manera?". Sin embargo, debemos tener en cuenta que en algunas jurisdicciones de la Unión Europea, la definición legal de violación trasciende el requisito de que el agresor utilice la fuerza física.

${ }^{102}$ Una información más detallada se puede obtener en la siguiente URL: http://fra.europa.eu/sites/default/files/fra-2014-vaw-survey-factsheet es.pdf 
- En la UE, el $18 \%$ de las mujeres han sido objeto de acoso a partir de los 15 años de edad, y un $5 \%$ de las mujeres lo habían experimentado en los 12 meses previos a la encuesta. Esto implica que 9 millones de mujeres fueron víctimas de acoso en un periodo de 12 meses.

- En torno al $12 \%$ de las encuestadas indicaron que habían experimentado alguna forma de agresión o incidente sexual por parte de un adulto antes de los 15 años, lo que equivaldría a 21 millones de mujeres.

- Los resultados revelan que el $30 \%$ de las mujeres que han sido víctimas de agresiones sexuales por parte de su pareja actual o de las anteriores, habían sufrido también violencia sexual en la infancia.

La violencia contra las mujeres se encuentra sostenida en un modelo inter-relacional construido socialmente, anclado en la restricción emocional y en la obsesión por el éxito. El varón ganador ha de estar sometido a un estado permanente de alerta y competencia, tratando de mostrar públicamente seguridad mediante la negación de sus sentimientos, que podrían asociarle con los más débiles. Es así como, en el marco de una sociedad patriarcal, el varón se ve impulsado a construir su identidad encubriendo, negando o evitando todo lo que es definido culturalmente como femenino (Romero Ramírez, 2003). Estas maneras de relación trascienden al ámbito privado como al ámbito laboral. El agresor habría desarrollado, además, esa tendencia de su personalidad mediante aprendizaje. La violencia es aprendida, sobre todo observando la conducta de modelos significativos tales como lo son los padres, hermanos o personas allegadas. Prueba de ello es que entre el 70 y el $80 \%$ de los maltratadores vivieron en su hogar situaciones de violencia durante la niñez, bien como víctimas directas, o bien como testigos de los malos tratos del padre hacia la madre (Romero Ramírez, 2003; Asociación Pro Derechos Humanos, 1999).

Precisamente es esa relación basada en el poder la que se subraya desde una perspectiva psicosocial y sociológica. Para la psicología social y la sociología, en la base del problema se encuentran las pautas diferenciales de socialización entre hombres y mujeres. En este 
sentido, el varón agresor suele ser una persona educada en un sentido tradicional (Stith \& Rosen, 1992), que trataría de hacer valer su autoridad imponiéndose sobre la mujer. Así pues, las creencias, las normas y los valores culturales juegan un papel trascendente en la configuración y en la promoción de la violencia contra las mujeres; a veces minimizando u ocultado sus efectos perversos y postergando el diseño de políticas y programas efectivos para erradicar tal violencia (Matud, Gutiérrez \& Padilla, 2004). La relevancia que adquieren las creencias y las normas la subraya Pilar Pastor (2007) cuando recuerda que todavía resulta cotidiano que se anime a un niño a devolver una agresión y a una niña a pedir ayuda si la recibe. La autora mencionada destaca la importancia extraordinaria que tiene la educación que corrige los modelos tradicionales de relación entre hombres y mujeres.

Según un estudio de la Fundación Mujeres y la UNED ${ }^{103}$, el 23\% de los chicos adolescentes entre 14 y 17 años conciben a las mujeres como inferiores y débiles; y el 35\% se muestran de acuerdo o muy de acuerdo con actitudes que justifican, niegan o minimizan la violencia de género. También puede resultar preocupante que en España el $17,7 \%$ de los hombres menores de treinta años esté convencido de que "el varón agresivo es más atractivo". Este dato revelador se puede conjugar con otro: sólo el 2,5\% de la ciudadanía considera que la violencia de género es un problema grave ${ }^{104}$. Por lo tanto, cambiar los estereotipos basados en prejuicios, actualmente vigentes, implica una necesidad de actuar sobre el aprendizaje social y la educación a corto, medio y largo plazo. Y que ello afecte y se refleje, además, en las políticas legislativas.

${ }^{103}$ La Fundación Mujeres y la UNED ponen en marcha en 2002 el 'Proyecto Detecta' con adolescentes entre 14 y 17 años.

${ }^{104}$ Resultados expuestos en el I Foro Internacional sobre Juventud y Violencia de Género celebrado en Madrid en noviembre de 2009 y promovido por el INJUVE. 


\subsection{Lo explícito y lo implícito, lo visible y lo invisible en las relaciones de pareja basadas en el poder y el miedo}

Puede entenderse, después de lo que se ha planteado, que las relaciones de pareja basadas en el poder y el miedo presentan diferentes formas porque la violencia es poliédrica. Las formas que adquiere pueden ser múltiples y complejas. Se reconoce muy bien la violencia física (donde se incluye la sexual) porque es manifiesta, explícita, se puede ver: deja huellas. De todas maneras, algo falla cuando el $52 \%$ de jóvenes varones no ve como un indicador de abuso de poder el que un chico obligue a "su pareja" a mantener relaciones sexuales.

La violencia psicológica, aunque es más difícil de reconocer, sus consecuencias son medibles (González de la Rivera, 2005). El Centro de Investigaciones Sociológicas, en un estudio de febrero de 2012 para conocer la salud de las mujeres españolas, obtiene como una gran conclusión que la violencia machista afecta a la salud biopsicosocial de las mujeres. Las que confesaron haber sido maltratadas también reconocían que su salud era mala: dolores de cabeza, de espalda, fatiga crónica, insomnio, ansiedad, tristeza, depresión o ideas autodestructivas. Dentro de la violencia psicológica se encuentran:

- La violencia verbal, que supone insultos o desprecios (gritos, amenazas);

- La violencia emocional, que incluye atacar los objetos que se saben son apreciados por la otra persona o atacar/controlar situaciones vitales: romper el ritmo del sueño, controlar la comida o la vestimenta, manejar las claves de acceso al correo electrónico, etc. En momentos extremos, atacar a los hijos/hijas que se tienen en común. Entonces ya no se habla de atacar objetos sino a "sujetos importantes". No quedan lejos de la memoria colectiva casos de asesinato de los propios hijos por venganza contra la mujer. 
- la violencia social: supone maltrato delante de terceras personas o el control de actividades que supongan estar con amistades. En este punto puede ser incluido el 'sexting' (Brown, Keller \& Stern, 2011). Este término anglosajón que une sexo (sex) con difusión de mensajes ('texting'), describe la acción de publicar contenidos de tipo sexual, que han sido recogidos con un dispositivo móvil y que inicialmente la propia persona perjudicada envió a un tercero que es quien reenvía. Esa información se difunde masivamente sin consentimiento de quien lo remitió y el trasfondo que hay es la venganza y el control.

La violencia estructural hace referencia a la exclusión social que se produce dentro de algunas comunidades o estados. Aquí también puede incluirse la violencia económica o la feminización de la pobreza. La violencia estructural marca la vida cotidiana de manera contundente. Puede llamar la atención, y considerarse alejado de la realidad del primer mundo, que haya países donde las mujeres no pueden conducir un vehículo en pleno siglo XXI como es el caso de Arabia Saudita, lo cual significa que las mujeres no son consideradas personas jurídicas plenas. Sin embargo, en el denominado "primer mundo" también se producen situaciones que ponen de manifiesto que la desigualdad es real y está cristalizada en la vida social. Un ejemplo lo suponen los salarios; unos salarios que mantienen significativas diferencias entre mujeres y hombres (Lago Peñas, 2002; Simón, 2006). Existen otras cuestiones que pueden ser menos visibles pero igual de reales. Es el caso de liga profesional de fútbol; en pleno 2014 las futbolistas en España no pueden ser profesionales porque sólo puede existir una liga profesional. Ello deja en evidencia que la estructura del Estado es absoluta e incompresiblemente patriarcal (Marugán Pintos, 2012).

La violencia simbólica hace referencia a la imposición de significados prejuiciosos sobre el rol o sobre los rasgos que se le atribuyen a una persona (o a un grupo de personas) desde la propia familia, la comunidad de referencia, la educación o desde los medios de comunicación (Núñez Domínguez y Troyano, 2012b). Y esa 
atribución de rol $^{105}$ o de rasgos ${ }^{106}$ a veces es clara y abierta pero muchas otras tienen un carácter sutilísimo. Es posible y pertinente matizar el sexismo simbólico (o la violencia simbólica) haciéndose referencia a:

a) la violencia ambivalente,

b) la violencia condescendiente $y$

c) la violencia benevolente.

La violencia ambivalente se produce cuando la persona experimenta un conflicto emocional entre los sentimientos positivos y negativos que le despierta una mujer. Ese conflicto puede representarse por la siguiente idea: 'las mujeres son iguales que los hombres pero se me hace raro tener a una jefa'. En la película Acoso (Estados Unidos, 1994) se nos presenta a una jefa víbora, venenosa, enferma de ambición. Unir ambición con maldad es perverso porque genera la idea de que las mujeres ambiciosas son malas. Así pues, las mujeres no deben tener ambición pero eso mina el legítimo derecho a progresar laboralmente. Es la filosofía de la película El diablo se viste de Prada (Estados Unidos, 2006), donde una verdadera Cruela de Vil acosa a todo el personal a su cargo. Es despiadada, insoportable. Por su parte, la Sra. Smith de la película Sr. y Sra. Smith (Estados Unidos, 2005) es una jefa estupenda en ese sentido odioso de la palabra estupenda, en cuanto que se fomenta la pervivencia de la creencia compartida basada en la consideración de que tiran más dos tetas que dos carretas. Con una consecuencia indeseable: hace que se pierda, que se diluya la profesionalidad de una mujer frente a su frivolidad. En esa línea de jefa-sexy está Sandra Bullock en La proposición (Estados Unidos, 2009). Es una jefa pertinaz, centrada en su trabajo y, por eso, deshumanizada, insoportable. Evidentemente tiene un final feliz ( $\dot{e} ?)$,

\footnotetext{
${ }^{105}$ Entender a las mujeres como las "reinas" de la casa, por ejemplo, o las perfectas cuidadoras de la familia.

${ }^{106}$ Considerar a las mujeres emotivas y de lágrima fácil y a los hombres racionales o a las mujeres débiles y a los hombres brutos.
} 
termina con una mujer enamorada y "entregada" a un hombre, aspiración que se le asigna a cualquier mujer decente.

Por violencia condescendiente entendemos que la desigualdad se ve como algo incorrecto pero se hacen peticiones injustas a las mujeres. El prejuicio estaría en la idea de que las mujeres han de hacerlo todo y todo bien. Se plasmaría en la siguiente proposición: "puedes salir al mundo profesional siempre que no abandones el cuidado de la casa y de la familia, que (naturalmente) te corresponde". Un ejemplo puede encontrarse en la película Erin Brockovich (Estados Unidos, 2000). Esta mujer es una gran luchadora, creativa, auténtica "buscavidas" y como no se rinde, después de mucho esfuerzo logra un trabajo remunerado. Está mal pagada pero no le importa, cree en su proyecto; además, cuenta con una relativa buena autoestima y el esfuerzo invertido le permiten demostrar su valía. Así que logra triunfar. Sin embargo, a lo largo de la cinta están presentes dos estereotipos absolutamente prejuiciosos:

- Relación de responsabilidad de las mujeres con el cuidado de la infancia y la adolescencia.

- El espacio propio de las mujeres es el mundo privado; aunque pueden salir al mundo público siempre que no abandonen el privado.

Es decir, la mujer tiene que cuidar a su familia porque es su misión (dice el primer estereotipo prejuicioso). Así pues, lo biológico, que marca a la mujer para que pueda parir está teñido por aspectos sociales y culturales: criar, educar, atender, que son comportamientos no necesariamente unidos a un género concreto pero se le adjudica a las mujeres y que le genera culpa si no cumple con el mandato social. $\mathrm{El}$ otro estereotipo unido al primero es, si cabe, más perverso porque señala que la mujer puede salir al mundo público, al mercado laboral, sin abandonar "sus labores" domésticas, que le corresponden en cualquier caso. En la película El método (España, 2005) vemos a una mujer ambiciosa pero que termina renunciando a su proyecto laboral por amor. La que se le recuerda (especialmente en los últimos veinte minutos) que tal vez debería elegir entre tener descendencia y 
progresar en el trabajo. Eso nunca se le pide a un hombre. Existen parámetros de medición sobre la consideración y expectativas que mujeres y hombres mantienen sobre el éxito (Coria, 1993) que permiten entender los argumentos en los que se sostienen errores sociales que conducen a percepciones e ideas que favorecen el mantenimiento de prejuicios sexistas como los descritos.

La violencia benevolente es aquel comportamiento amable, cortés, protector, afectivo... para aquellas mujeres que cumplan con su rol tradicional de ama de casa, de cuidadora de la familia, de reina y guardiana del hogar. Se puede ver muy bien en la escena de la película Los puentes de Madison (Estados Unidos, 1995) que se transcribe a continuación:

- Clint Eastwood: Supongo que a usted le gustará vivir el Iowa. Sincérese.

- Meryl Streep: Yo sé que debería decir que es estupendo, que es tranquilo, la gente es buena... Y en cierta manera es así... Hay muchas cosas agradables de la gente de por aquí, pero...

- Clint Eastwood: Pero...

- Meryl Streep: Pero no es lo que yo soñaba cuando era joven.

- Clint Eastwood: ¿Le gustaba la enseñanza?

- Meryl Streep: Sí, a veces sí. Sobre todo cuando había un estudiante determinado que te interesaba más. Con todos había que hacerlo, pero no es así. Se tiende a escoger a uno o dos, a quienes crees que puedes contribuir en algo...

- Clint Eastwood: ¿Y lo hizo?

- Meryl Streep: No sé, espero que sí. Creo que uno estudió Medicina...

- Clint Eastwood: ¿Y por qué lo dejó?

- Meryl Streep: Por mis hijos. Por ellos. Además, a Richard no le gustaba que yo trabajara.

- Clint Eastwood: Pero se nota que lo echa de menos.

- Ella cambia de tema 
Es querida porque deja su profesión por el cuidado de su familia. Se la 'trata bien' porque hace las cosas que se esperan de una mujer cabal. Un ejemplo más unido a la vida real y no a la ficción. El experto en el Corán Malik Ibn Benasia decía en una mezquita de Ceuta: "Las mujeres musulmanas no deben salir a la calle más que con las manos y el óvalo de la cara descubiertos y no utilizar vaqueros, zapatos de tacón o perfume para no ser consideradas unas fornicadoras".

Puede resumirse lo expresado con el siguiente esquema:

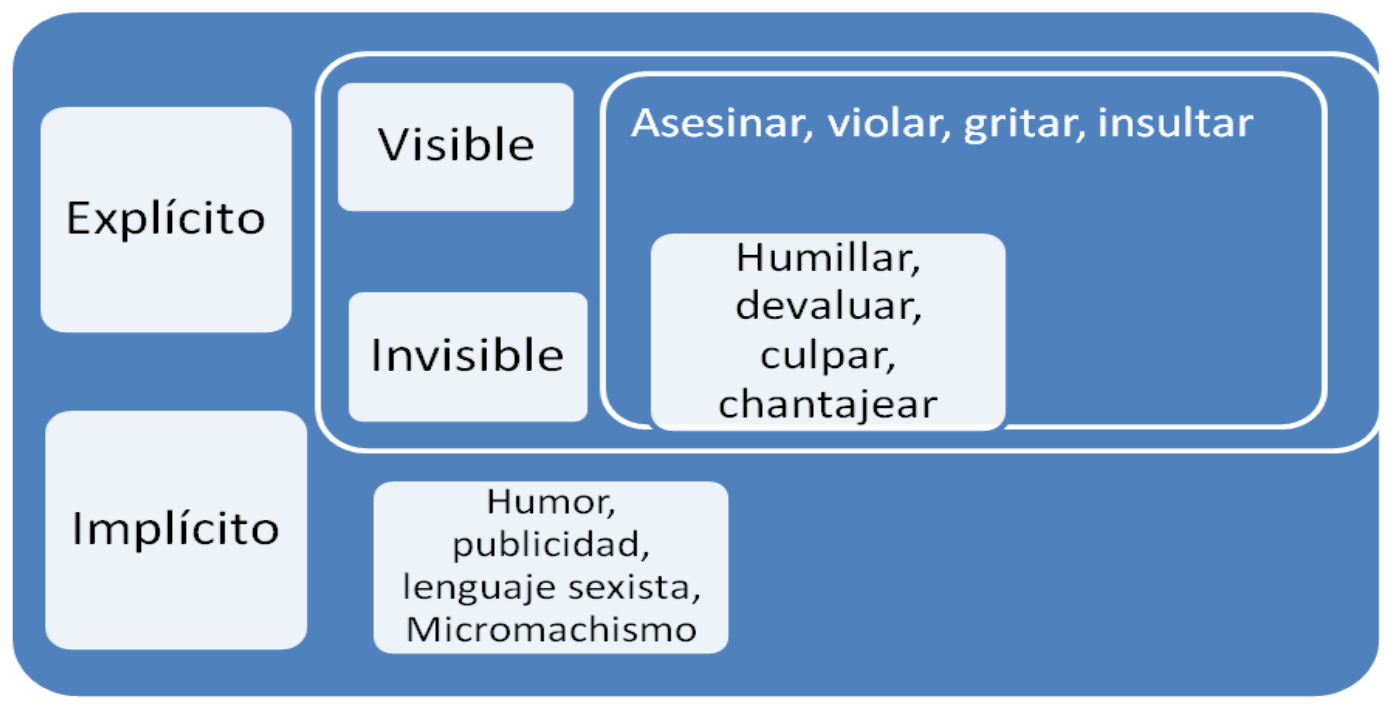

Resulta destacable esa 'parte oscura', implícita e invisible manifestación de la violencia: el humor, la publicidad y el lenguaje sexistas y las relaciones micromachistas.

Luis Bonino (1998) es una de las primeras personas que describe y profundiza en este tipo de relación basada en el poder y el miedo. El micromachismo se define como una serie de prácticas cotidianas, la mayoría de las veces imperceptibles, que incluyen pequeños abusos y violencias. Atenta contra la autonomía de la mujer y se produce en un nivel micro (de intensidad baja) aunque su constante repetición termina dejando huella en la persona. Los objetivos de ese tipo de práctica se pueden resumir en, al menos, tres: mantener el dominio; reafirmar o recuperarlo y resistirse al aumento de poder personal o interpersonal de una mujer con la que se está vinculado. El 
mencionado autor los divide en cuatro los tipos de micromachismos: a) utilitarios (como no llevar a efecto la corresponsabilidad doméstica y de cuidado de la familia o del hogar); b) encubiertos (como los engaños, las infidelidades o los silencios); c) coercitivos (como las coacciones comunicativas o el control del dinero) y d) de crisis (como rehuir la crítica y la negociación). Son prácticas de dominación masculina en la vida cotidiana cimentadas en la sutileza social/cultural, se quedan al límite de la evidencia y pueden ser aplicadas, también, por aquellos hombres autodenominados 'los menos machista del mundo', cuyo estilo de vida de primera mano pudiera parecer muy lejano del modelo masculino de las décadas pasadas (Ramírez García, 2013). Estos comportamientos ejercen efectos dañinos en las mujeres y en las relaciones familiares. No se circunscribe al hogar o relación con la pareja, se da en el propio contexto de la sociedad, en las relaciones laborales.

Respecto a la publicidad sexista sutil, tenemos como ejemplo de una práctica perversa anuncios que contraponen el cuidado y la belleza personal con el desempeño profesional. Se sigue presentando a mujeres frívolas, más preocupadas por su belleza y por el coqueteo que por el trabajo que realizan. La consecuencia es clara y devastadora: las mujeres no van a ser percibidas como unas profesionales serias. Un caso preocupante es el de anuncio de una marca de farmacéutica ocupada por los resfriados y gripes. Este anuncio es del otoño-invierno de 2009 (octubre-enero). Se muestra una escena familiar donde una mujer le dice al marido "tengo que salir a trabajar". Este, con cara compungida le responde: “ ¿y me vas a dejar solo con lo malito que estoy?". Ella responde: "he llamado a la canguro de los niños...". Entonces aparece una chica de unos diecisiete años, rubia, delgada, bajando con su melena al aire por unas escaleras. Se añade un primer plano de él y de su cara de felicidad. La esposa sigue diciendo: "pero como no podía venir..., he llamado a mi madre". El marido, entonces, se toma corriendo la medicina (para evitar a la suegra); se ha desvanecido 'su sueño'. Lo que se está subrayado es que el cuidado de las personas de la familia siempre debe estar en manos de las mujeres. En paralelo, se subraya que las jóvenes guapas son verdaderos objeto de deseo y no profesionales 
capacitadas (Núñez Domínguez y Troyano, 2012a). Éste es sólo un ejemplo de los numerosos que pueden ser encontrados en los últimos años.

\section{A modo de cierre}

Es trascendente seguir interviniendo en la sensibilización ciudadana de la misma manera que debe mantenerse la investigando para el cambio social y la formación en género desde edades tempranas y en los centros de trabajo. En paralelo, se ha de legislar y exigir el cumplimiento de la ley para garantizar la igualdad de trato. Consideramos de relevancia el nuevo paso que previsiblemente se va a producir en el Código Penal español en 2015 si se acepta una enmienda $^{107}$ al artículo 510. Ello supone penar con prisión la justificación o el enaltecimiento de delitos, la humillación o el menosprecio, la incitación o la promoción del odio por razón de género. Hasta ahora, atendiéndose al artículo citado se castigaba la violencia por racismo, antisemitismo, religión, creencias, situación familiar, etnia, raza, nación, origen nacional, sexo, orientación o identidad sexual, enfermedad o discapacidad. Se especifica que la prisión o las multas "se impondrán en su mitad superior" cuando la apología circule "a través de un medio de comunicación social, por internet o por tecnologías de la información", apuntándose como responsables no sólo a particulares sino a empresas de comunicación.

\section{Referencias bibliográficas}

Arias, A. (2007). "Psicología social de la agresión". En J. Francisco Morales (coord.), Psicología social. Madrid: McGraw Hill, págs. 415440

Bandura, A. (1982). Teoría del aprendizaje social. Madrid: Espasa-Calpe. Bonino, L. (1998). Micromachismos: la violencia invisible. Madrid: Cecom

\footnotetext{
${ }^{107}$ Se trata de la enmienda 869 y es la portavoz del PP en la Comisión de Igualdad el Congreso, Marta González, quien la propone; aunque hay muchas otras mujeres (representantes de todos los partidos políticos) las que trabajan en este sentido.
} 
Brown, Jane; Keller, Sarah \& Stern, Susanna (2011) Sex, Sexuality, Sexting, and SexEd: Adolescents and the Media. Prevention Researcher, 16 (4), págs. 12-16

Coria, C. (1993). Los laberintos del éxito: ilusiones, pasiones y fantasmas femeninos. Barcelona: Paidós.

González de Rivera, J. L. (2005). El maltrato psicológico. Madrid: Espasa Guerrero Muñoz, J. (2008). La sociedad extrema. Debates sobre la violencia. Madrid: Tecnos.

Hogg, M.A. \& Vaughan, G.M. (2010). Psicología social. Madrid: Panamericana

Lago Peñas, I. (2002). La discriminación salarial por razones de género: un análisis empírico del sector privado en España. Reis, 98, págs. 171-196

López Zafra, E. (2007) "El componente cultural de la violencia”. En J. Francisco Morales (coord.), Psicología Social. Madrid: McGraw Hill, págs. 441-454

Leyman, H. (1996). The content and development of mobbing at work. European Journal of Work and Organitzational Psichology, 2.

Marugán Pintos, B. (2012) Domesticar la violencia contra las mujeres, una forma de desactivar el conflicto intergéneros. Investigaciones feministas, 3, págs. 155-166

Matud, Ma P., Gutiérrez, A. B., Padilla, V. (2004). "Intervención psicológica con mujeres maltratadas por su pareja", Papeles del Psicólogo, 88. Recuperado (diciembre 2014) de

http:/ / www.papelesdelpsicologo.es/vernumero.asp?id=1155

Núñez Domínguez, T. \& Troyano, Y. (2012a). La violencia machista en el cine. Materiales para una intervención psicosocial. Madrid: Delta Publicaciones

Núñez Domínguez, T. \& Troyano, Y. (2012b). "La violencia machista en el cine. De la revisión videométrica a la intervención psicosocial”. Revista Europea de Derechos Fundamentales, 19, págs. 295-318

Pastor, P. (2007). “¿Qué significa ser victimario y víctima de la violencia de género?”. Recuperado (diciembre 2014) de 
http://www.ciudaddemujeres.com/articulos/Que-significa-servictimario-y

Ramírez García, B.O. (2013). "El micromachismo. La violencia invisible”. Sapere Aure, 3, págs. 61-76

Romero Ramírez, A.J. (2003). La maté porque era mía: una aproximación psicológica y social a la violencia doméstica. Encuentros en Psicología Social, 1(5), págs. 140-142.

Simón, H. (2006). Diferencias salariales entre hombres y mujeres en España: una comparación internacional con datos emparejados empresa-trabajador. Investigaciones Económicas, XXX (1), págs. 55-87

Tolan, P. \& Gorman-Smith, D. (2002). What violence prevention research can tell us about developmental psychopathology. Development and psychopathology, 57, págs. 557-583.

Van de Vliert, E.; Aukje Nauta, E.; Onne J. (1999). Constructive conflict at work. Journal of Organizational Behavior, 20 (4), págs. 475-491 World Health Organization (2002). World Report on Violence and Health: Summary. Geneva: WHO 


\title{
De violencias, procesos de resignificación y ciberfeminismo
}

\author{
María José Gámez Fuentes \\ Laura Castillo Mateu \\ Universitat Jaume I
}

\section{Introducción}

T A intención del presente trabajo es avanzar en el debate sobre la Lvisibilización de las historias de violencia de género sufridas por las mujeres en las plataformas online. Lo que pretendemos es ver cómo el activismo feminista articula estrategias de empoderamiento basadas en el recurso del "testimonio ético" (Oliver, 2004) con el objetivo de subvertir la condición de víctima de maltrato y de contribuir a la reconfiguración de la identidad del sujeto pasando de un sujeto pasivo -victimizado- a un sujeto "agente" (Butler: 1990) la superviviente-adscribiendo valor político al proceso testimonial.

Para ello abordaremos hasta qué punto las estrategias sinérgicas desde lo on y off-line, creadas desde el activismo feminista más reciente, han contribuido a la ruptura de lo que hemos denominado paradigma 
de la victimización, al cual se asocia la imagen de las mujeres que han padecido casos de violencia de género en alguno o varios momentos de su vida. Nos interesa poner de relevancia cuán importante resulta reconocer a estas mujeres desde otro paradigma, el de la superviviente, como premisa ineludible en su inclusión en el proceso político para la erradicación, por una parte, de la violencia de género y, por otra, de la desigualdad entre hombres y mujeres (si es que en algún momento alguien quiso entender lo uno sin lo otro). En ese sentido, examinaremos cómo se pueden construir, desde el discurso en red, relaciones de alianza que contribuyan a la emancipación política de las mujeres maltratadas y qué papel juega la dación de testimonio en todo este proceso de empoderamiento cuando éste pasa a formar parte del relato colectivo en lugar de ser el trámite necesario para el inicio de un episodio de vida judicializado y, por tanto, individual y socialmente traumático.

Para ilustrar esos posibles avances discursivos que, sostenemos, se están dando en esta línea nos valdremos del caso de las plataformas online de las asociaciones agrupadas en la Federación RAMMAS (Red de Apoyo a Mujeres Maltratadas por Asociaciones de Mujeres Supervivientes de Violencia), cuya presentación oficial se produce en el marco del primer congreso de mujeres supervivientes, realizado en Valencia en noviembre de 2013. Nos interesa ver las prácticas discursivas en las que basan su ciberactivismo para la inclusión efectiva de las víctimas de maltrato en el proceso de empoderamiento y en los procesos políticos de activismo feminista.

\section{Violencia de género y marcos de reconocimiento}

"Es evidente que sufrimos un retroceso en el combate contra la violencia de género y por la igualdad. Es un retroceso visible no sólo en el número creciente de asesinatos machistas, sino también en que estos se producen en un ambiente social, legal, mediático, ideológico, diferente. Si nunca fue mucho el interés social hacia la violencia de género, ahora parece haber caído aún más. Los medios de comunicación, si alguna vez intentaron informar correctamente acerca de los asesinatos machistas, han vuelto a su querencia por informar de manera morbosa y 
apolítica, por privatizar esta violencia y por volver a intentar justificarla. Los neomachistas, [...] si antes se escondían, ahora se hacen visibles" (Gimeno, 2014).

Este fragmento nos sirve para esbozar brevemente los rasgos de la configuración político-mediática en la que se imbrican actualmente las agendas feministas en España: los movimientos feministas advierten del retroceso sufrido en materia de igualdad de género en el contexto político estatal desde la crisis. Todo esfuerzo realizado en el marco normativo contra la violencia machista -el estandarte de la lucha de los partidos en materia de igualdad- se percibe inversamente proporcional a la magnitud de las actitudes y reacciones sexistas presentes en el discurso mediático y en la red. Por el contrario, la praxis feminista ha incrementado su visibilidad, su labor activista y la canalización de la misma a través de las redes sociales (Núñez Puente, 2011), de forma directamente proporcional al agravio en la preservación derechos por parte del Estado y la retirada de la tutela de las víctimas (presentes y potenciales) de maltrato. Mientras los discursos (políticos, mediáticos o en red) convencionales se aferran a la fetichización de la mujer mediante la perpetuación de la identificación con el rol de víctima (Gámez Fuentes y Núñez Puente, 2013), la esfera online parece haberse convertido, en algunos casos, como veremos luego, en el medio a través del cual se promueve la figura política activa de la mujer superviviente, contribuyendo así a la resignificación personal y social de la sujeto.

En este contexto, Gimeno (2014) destaca la necesidad de "liderazgo institucional y político en la promoción de consensos sociales respecto a cuestiones [...] contrahegemónicas, como la igualdad de género". Según su análisis, la caída del PSOE en las elecciones generales de 2011 vino acompañada de un borrón de las "líneas rojas" marcadas por el discurso explícitamente feminista de líderes sociales y políticos que reforzaba un "ambiente social" legitimador de medidas institucionales del gobierno socialista en su última etapa en el ejecutivo. Como bien dice la autora, "por razones en las que aquí no vamos a entrar, es cierto que el PSOE hizo políticas feministas" 
(Gimeno, 2014) y ha sido, en parte, gracias al doble activismo ${ }^{108}$ del sector feminista dentro del partido que la agenda de género se incluyó en la agenda política estatal y que el marco legislativo esté dotado a día de hoy de una Ley de Igualdad. ${ }^{109}$ Pero tampoco es menos cierto que la institucionalización del feminismo (De Miguel, 1995: 18) ha tenido que someter sus principios a la lógica epistemológica patriarcal y que, posiblemente, por esta razón, todos los esfuerzos en este campo han derivado en una suerte de criminalización de las manzanas podridas de la sociedad -los maltratadores- como responsables únicos de las desigualdades. Con esto, nos referimos a que las campañas institucionales por la igualdad entre mujeres y hombres han parecido sucumbir al reduccionismo moral y penal de una única medida, esto es, la Ley contra la violencia de género, ${ }^{110}$ y que, por tanto, toda la problemática de la desigualdad ha quedado reducida a las categorías de víctima y maltratador-delincuente en el terreno de la representación mediática (Gámez Fuentes, 2012: 200-205), sin tener en cuenta que "la facilidad con la que se ha asimilado el sexismo con la violencia (sin una adecuada profundización en los debates de la teoría feminista sobre las relaciones de poder), unido al excesivo papel social del derecho penal en su abordaje, han acabado diluyendo las reivindicaciones de los movimientos feministas"(Gámez Fuentes, 2012: 205 ).

Tal vez por esta razón, y siguiendo la oportunidad marcada por las modas establecidas desde el plano político-institucional, el activismo on-line feminista ha enfocado sus estrategias a visibilizar y denunciar públicamente la violencia directa (entendiendo como tal la agresión física o psicológica) contra las mujeres en aras de concienciar a la sociedad y erradicar el fenómeno del así llamado terrorismo machista.

\footnotetext{
${ }^{108}$ Para ampliar información sobre la idiosincrasia del activismo feminista estatal, ver Gámez Fuentes (2015).

${ }^{109}$ Nombre completo: Ley Orgánica 3/2007 de 22 de marzo para la igualdad efectiva de mujeres y hombres.

${ }^{110}$ Nombre completo: Ley Orgánica 1/2004 de 28 de diciembre de Medidas de Protección Integral contra la Violencia de Género.
} 
No obstante, la sinécdoque conceptual resultante ha pervertido la idea emancipatoria originaria de las políticas de cariz feminista y en ocasiones ha resultado ser una caja de resonancia del marco institucional establecido sobre la disyuntiva víctima-maltratador.

En este sentido, algunos análisis llevados a cabo acerca de las acciones comunicativas tanto de asociaciones feministas como de instituciones estatales ponen en cuestión que el rol de la mujer representada contribuya a transgredir, desde lo performativo, la presupuesta pasividad de las mujeres maltratadas. Destacan, por ello, la necesidad de "conferir un carácter político y agencial al proceso de construcción del sujeto víctima de la violencia" (Núñez Puente et al., 2013: 181) mediante la exploración de nuevos modos de representación y denominación de este sujeto. Estudios posteriores en esta misma línea (Núñez Puente y Fernández Romero, 2015) corroboran que los artefactos audiovisuales ciberfeministas realizados desde las propias asociaciones y pensados -presumiblemente- desde los códigos activistas por la igualdad, se muestran reticentes a abandonar el carácter informativo de los relatos hegemónicos sobre violencia de género. Las autoras destacan que la única interpelación al sujeto víctima de violencia se asocia a la promoción de la denuncia judicial como única herramienta para salir de la situación privada de dominio y opresión. De esta manera, la acción se asocia a la búsqueda de asistencia, es decir, a la petición de "tutelaje" oficial desde los organismos públicos (Gámez Fuentes, 2012: 201).

Otra de las cuestiones que se perciben en el plano del activismo feminista on-line, es la suerte de lapso entre ciberactivismo y activismo más tradicional, u off-line. Es a lo que se refieren Fernández Romero et al. (2011: 71) cuando hablan de las "posibilidades de desarrollo del ciberactivismo social", es decir, las potencialidades sinérgicas entre ambas esferas, que todavía está por darse. Este es un asunto que debemos también tener en cuenta cuando analizamos las plataformas en la red, ya que a veces la presencia online puede no garantizar un uso dialógico y accesible de las mismas. 


\section{Transformación del marco: hacia un paradigma de la superviviente}

El principal problema, pues, con el que se encuentra el paradigma de la victimización es el del auto-reconocimiento de las propias maltratadas como tales. A partir del momento en que el imaginario sobre el que se asienta el concepto de víctima de violencia de género sucumbe a una suerte de reduccionismo representativo que asocia exclusivamente el problema del machismo a los episodios de crimen demostrable ante las autoridades pertinentes (Núnez Puente et al., 2013; Gámez Fuentes, 2012), el resto de mujeres que no se reconoce dentro de ese paradigma puede seguir viviendo en el conflicto generado por la desigualdad estructural subyacente (Gámez Fuentes, 2012).

Si, además, el terreno de la representación mediática a través de la cual se pretende interpelar al sujeto víctima de género (especialmente y en este caso, también, a través de las plataformas 2.0), sucumbe a este reduccionismo conceptual, resulta cuanto menos difícil presentar y concebir herramientas de acción que transciendan la denuncia presencial o telemática de los episodios de violencia física o psicológica por parte de las víctimas. $\mathrm{Y}$ es que las propias recomendaciones difundidas por el propio gobierno impulsor de la normativa por la igualdad y contra las agresiones machistas (Gámez Fuentes y Núñez Puente, 2013) parecen no tener más horizonte que el de la vía judicial.

Frente a este panorama, el asociacionismo feminista, a lo largo de estos diez últimos años, ha centrado también muchos de sus esfuerzos en mitigar las carencias pedagógicas a favor de la igualdad de género que se han ido dando y detectando en los ámbitos formales e informales. Atendiendo a lo nombrado con anterioridad, no resulta extraño que las motivaciones discursivas sobre o desde las que han ido replanteando sus estrategias (dejando, de momento de lado, su carácter informativo, neutro y/o distante) partan de la duda sobre las alternativas representacionales existentes para las mujeres más allá de la víctima y más allá del recurso al proceso judicial. 
Para ilustrar los últimos avances en este sentido, tomaremos como objeto sintomático la red de mujeres supervivientes integrada bajo la Federación RAMMAS (Red de Apoyo a Mujeres Maltratadas por Asociaciones de Mujeres Supervivientes de Violencia), ${ }^{111}$ la cual congrega a los siguientes grupos de mujeres asociadas: Fundación Ana Bella, Mujeres que Aman Demasiado-Bilbao, Mujeres Unidas contra el Maltrato (M.U.M.), Mujeres al Cuadrado, Amigas Supervivientes, Mujeres Supervivientes en Acción (M.U.S.A.), Mujeres Supervivientes de Violencia de Género, Hombres y Mujeres en Acción Positiva, Madres Progresistas de Albuquerque, Renacer Violeta y Despertar sin Violencia. ${ }^{112}$

En la página de inicio del blog de RAMMAS, encontramos dos entradas con la misión de la federación, ambas del 1 de diciembre de 2013, en las que se presentan su objetivo y razón social como organización. Como señalábamos al inicio, la fundación asocia su constitución como tal a la celebración del I Congreso Internacional Ana Bella de Mujeres Supervivientes celebrado en Valencia el 28 de noviembre de 2013. Resulta significativo que el lema con el que inician su presentación diga que "las mujeres maltratadas no son el problema son parte de la solución" y que destaquen, para acabar, que "por primera vez las mujeres que han sido maltratadas son noticia, no porque han muerto, sino porque han cambiado el mundo". Esta

\footnotetext{
${ }^{111}$ Dirección del blog: http://federacionrammas.blogspot.com.es

${ }^{112}$ Direcciones web: http://www.fundacionanabella.org;

http://mujeresqueamandemasiadobilbao.blogspot.com.es;

http://www.asociacionmum.org;

http://andretxea.kzcomunidades.net/es/html/AsociacionesdeMujeresdeEibar/ MujeresalCuadrado/19/57.shtml;

http://andretxea.kzcomunidades.net/es/html/AsociacionesdeMujeresdeEibar/ MujeresalCuadrado/19/57.shtml;

https://www.facebook.com/musa.mujeressupervivientesenaccion; http://mujeressupervivientes.org; https://twitter.com/anamariaalvero; https://www.facebook.com/pages/ASOCIACION-DE-MADRESPROGRESISTAS-DE-ALBURQUERQUE/121476101262743; https://www.facebook.com/pages/Juana-Melian/285361138253993; http://www.despertarsinviolencia.org.
} 
declaración de intenciones marca desde el inicio un paso hacia delante en el plano agencial, en tanto que subsanan algunas de las carencias de las que hablamos más arriba.

Esa agencia se pone de manifiesto a través de los testimonios que encontramos en los vídeos de presentación de las asociaciones federadas. La presentación del testimonio por parte de las mujeres supervivientes, que dan la cara y la voz sin sombras ni distorsiones, resulta una característica común a todos ellos.

Centrémonos, por ejemplo, en el caso de la Fundación Ana Bella, ${ }^{113}$ que da nombre al congreso y es fuente de inspiración de muchas otras asociaciones de amigas de víctimas de violencia de género. En la web de esta fundación predomina el blanco y el rosa, y se distinguen de manera clara las tres líneas de acción en las que basan su activismo: la Escuela (para la formación y la inserción laboral de las mujeres), el Programa Amiga (que funciona como red interdisciplinar de apoyo para el empoderamiento de las mujeres) y, la base sustentadora de las dos anteriores: los Testimonios Positivos. Además, antes de llegar a estos tres apartados informativos y de acceder a las entradas del blog de la fundación, encontramos el banner de la parte superior de la página de inicio en el que se aprecia, de medio perfil pero sin dificultad alguna, la cara de Ana Bella en una escena en la que parece hablar con actitud sonriente a otras dos mujeres que aparecen de espalda pero que visten, como ella, la misma camiseta rosa chicle. Al lado derecho, sigue un acceso directo a un vídeo sito en su canal de YouTube y que corresponde a la campaña Pa'lante Mujer. Vemos en el collage que ilustra el vídeo un abanico de caras de mujeres que miran de frente y con una sonrisa a la cámara. Esta marca enunciativa revela

${ }^{113}$ Para saber más sobre la historia de Ana Bella y sus motivaciones activistas, ver la charla ofrecida en la jornada TEDxBurgos:

https://www.youtube.com/watch?v=U8M 02PlgAk.

La Fundación basa su activismo en la formación en igualdad de las propias supervivientes para convertirlas en agentes de cambio social o, como su promotora dice, "emprendedoras sociales". 
el tono positivo y (re)constructivo del mensaje que encierra el relato del vídeo.

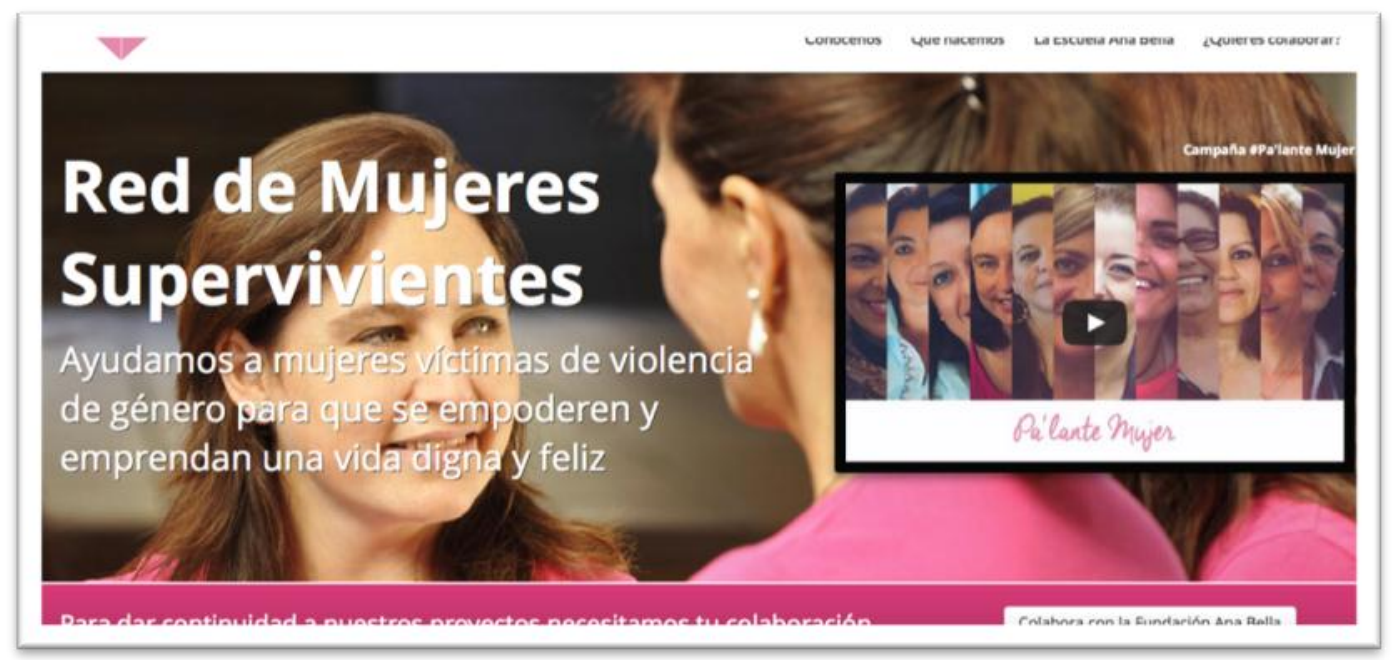

De la misma manera que ocurre en el vídeo de la campaña de la Fundación Ana Bella, otros vídeos de otras asociaciones muestran mujeres que explican, seguras y desde lo personal, qué es la violencia de género y qué valores y actitudes les ayudaron a salir de esas situaciones. En el caso, por ejemplo, de M.U.M., hablan de "crear una familia de mujeres con una nueva vida independiente y libre", mientras unos acordes alegres y desenfadados de una mandolina suenan de fondo. En otras web, como la de Despertar sin Violencia, abundan las fotos de las mujeres y de los actos institucionales en los que aparecen como lobbies.

El mensaje resulta indudablemente alentador y funciona como respuesta a la pregunta: ¿qué hay después de la huida? ¿Quién me va acompañar y ayudar el día después? El material gráfico y audiovisual de las webs da la respuesta: ellas, las propias supervivientes dicen que será con ellas con quienes se encontrará la ahora víctima tras dar el paso y dejar la situación de maltrato. Estas personas cuentan que han tenido, si no las mismas, similares necesidades a las de la mujer que busca una salida a través de la red. Las supervivientes ofrecen su testimonio en positivo y su apoyo con el objetivo de garantizar recursos de todo tipo (asesoría legal, psicológicos, asociativos, formativos y laborales) para que la víctima se reconstruya una identidad autónoma y libre. 


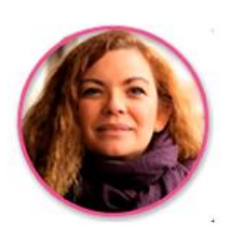

Carmen

Presidenta y Superviviente

"Mi intención al crear MUM es hacer una pequeña familia c

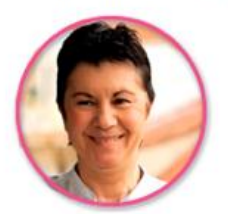

Consuelo

Tesorera y Coordinadora de Eventos

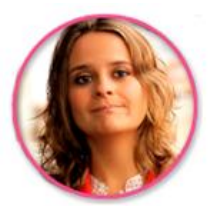

Rocío

Atención Directa Usuarias

"Hay alguien en quien puedes apoyarte. No estás sola para salir de ello. vuelvas a controlar tu vida"

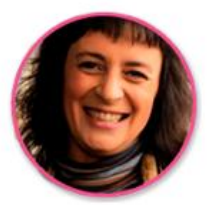

María

Superviviente y Voluntaria

"El amor no es lo que estás viviendo. Cuando sales, te sientes nacer otr.

Vemos, pues, que en los discursos presentes a través de RAMMAS existe una voluntad explícita de ruptura del paradigma de victimización en el que se ha incurrido de forma sistemática tanto desde las políticas institucionales como, en ocasiones, desde las activistas. Esa ruptura discursiva se encamina hacia un giro conceptual a favor del empoderamiento de las víctimas de la violencia machista al referirse a ellas como "supervivientes". Esta nueva denominación resulta mucho más operativa en términos políticos, ya que permite acceder al asunto de las agresiones que padecen las mujeres desde la raíz social del problema: la cultura patriarcal como origen de la violencia, la complejidad del carácter relacional que la sustenta y la responsabilidad de todos/as en su subjetivación.

Mientras en el paradigma de la victimización, la condición de la mujer víctima performativiza la pasividad de un sujeto carente de tutela una vez despojada de la responsabilidad de la denuncia, el de superviviente pone en primer plano la agencia de ese sujeto padeciente, que no paciente -pasivo-, de la violencia. En este proceso de resignificación del discurso, observamos cómo, a través de la web, la acción asociacionista se desarrolla en el acompañamiento de la mujer en el proceso de reconocimiento de las muestras de violencia hacia 
ella, más allá del ámbito privado de la pareja. Por otro lado, el valor del testimonio se integra como parte del activismo feminista contribuyendo a una labor de visibilización más pedagógica que informativa.

La red de plataformas online señaladas se erige intencionalmente como el componente fundamental para que las mujeres articulen esas relaciones de alianza a partir de las cuales generar espacios seguros de comunicación en los que compartir experiencias y deconstruir la violencia cultural y estructural desde sus historias de vida. El proceso de empoderamiento y de transformación del conflicto personal como padeciente de malos tratos viene aparejado al anterior: a medida que la autonomía de la mujer maltratada va reconociendo su posición política en el contexto desde el que ha construido y construye su identidad como mujer, ciudadana de pleno derecho, y no como sujeta definida a partir de su condición de víctima protegida por el Estado.

Es especialmente remarcable la habilitación de ese espacio propio, seguro, de comunicación a través de las plataformas online, reproducido a nivel físico con anterioridad o posterioridad al contacto con las miembros de la red activista en cuestión, según el caso. Este espacio es el que permite una emancipación más provechosa -en términos de sensibilización y transformación del conflicto- de las mujeres atrapadas en una situación de violencia de género, en tanto que no reduce su agencia y su responsabilidad a la petición de asilo al Estado a través de la denuncia. El factor del testimonio, el acto del "giving acount of oneself" -dar cuenta de uno/a mismo/a-, (Butler, 2009), deja de ser el paso previo a un proceso judicial traumático siguiendo la lógica reduccionista del paradigma de la victimizaciónpara ser un recurso de empoderamiento social inclusivo.

En este sentido, podemos decir que el espacio discursivo que encontramos bajo RAMMAS posibilita compartir relatos $y$ experiencias desde una concepción del testimonio que lo situaría en la línea de lo que Oliver (2004) denomina "ethical witnessing" (testimonio ético). Este concepto remite a la posibilidad de construir un marco de interpelación que no subsuma el testimonio del otro dentro de una matriz de inteligibilidad establecida si no que se 
enmarque en un contexto cuyo reconocimiento de ese otro se construya sobre la asignación de responsabilidad del sujeto que recibe el acto de testimoniar. En otras palabras, consiste en adscribir valor político al acto de ofrecer un testimonio a través de la asignación de responsabilidad al sujeto (testigo) que lo recibe.

Estos espacios virtuales, y su continuación en los reales, ofrecen la posibilidad de que sean las propias mujeres quienes construyan de forma colectiva las herramientas que les hagan sentir que son conscientes de la -mucha o poca- sensatez de sus decisiones y, por tanto, también responsables de ellas con sus consecuencias deseables o no. Y ahí precisamente es desde donde el proceso de "accountability" -rendir cuentas- (Butler, 2009) resulta eficaz en términos pedagógicos, en tanto que la resolución del conflicto pasa de (tener que) estar exclusivamente en manos de la autoridad/Estado a ser transformado desde los múltiples escenarios de acción en los que se manifiesta la cultura patriarcal que, al fin y al cabo, sostiene y justifica las agresiones contra la integridad personal y jurídica de las ciudadanas.

En ese sentido, un paradigma del reconocimiento de la condición de superviviente resulta también operativo para la causa feminista en tanto que el activismo, no necesariamente explícito y declarado, de estas supervivientes se traslada al ámbito personal, incluyendo así en el proceso de transformación social a las demás partes implicadas en la perpetuación de los roles tradicionales de género.

\section{Conclusiones}

Reducir o fijar el problema socio-cultural del patriarcado, transversal e imbricado en las estructuras, a un a asunto judicial y de potestad estatal, resulta problemático si se mira desde el potencial pedagógico de las experiencias que, en un principio, debería haber asegurado una perspectiva real de género en la configuración y asimilación de la Ley de Igualdad. Desde su aplicación, el activismo feminista online ha estado complementando la labor institucional desde esa perspectiva pedagógica, aunque en ocasiones haciendo de caja de resonancia de un marco de reconocimiento establecido desde la política 
institucional. Ahora bien, en su continua lucha por avanzar en la configuración de un sujeto político mujer, y al albor de recientes cambios socio-políticos en materia de derechos de las mujeres (Gámez Fuentes, 2015), se han dedicado especiales esfuerzos a la divulgación de códigos epistémicos desde los que entender y desarmar la violencia cultural que motiva la violencia. En ese proceso se detectan carencias sistémicas de un marco victimizador, de carácter paternalista que, al final, no permite la emancipación de la mujer, en términos de empoderamiento personal y de responsabilidad social que implica la rendición de cuentas de nuestros actos (Butler, 2009).

El asociacionismo y las iniciativas feministas en pro de la igualdad y en contra de la violencia de género han ido redirigiendo sus estrategias a medida que detectaban las necesidades sociales que se manifestaban en la aceptación o rechazo ciudadano de los marcos normativos y teóricos promovidos desde lo institucional. Precisamente este giro discursivo hacia una nomenclatura explícitamente empoderadora es sintomático de esas carencias operativas con las que los colectivos feministas se han topado tras el logro de la incorporación de los asuntos de género en el marco legal y, por tanto, en la agenda política estatal.

Plataformas como RAMMAS, por el contrario, enriquecen y dan valor a la figura del testimonio y a la necesidad de crear espacios seguros de comunicación desde los cuales crear alianzas políticas desde los relatos personales. $\mathrm{Y}$ es que, efectivamente, el asociacionismo feminista on y off-line, dedicado a la lucha contra la violencia machista y revisor de marcos de referencia, resulta especialmente vital en tanto que revaloriza y resignifica el eslogan feminista que "lo personal es político". La visibilización discursiva de las experiencias de las mujeres a través de sus testimonios es necesaria pero no desde una matriz victimizadora y sancionadora si no desde un marco que legitime dicho testimonio en tanto que interpelador relacional de las posiciones que ocupamos todos/as como testigos de sus relatos.

Si desplazamos el nivel perceptivo desde aquel sistema reduccionista víctima-delincuente hacia uno más realista y -por tanto- complejo, 
veremos que una vez detectado el hecho de que la violencia cultural patriarcal se manifiesta en todas las facetas de la vida, resulta superficial asociar la violencia de género exclusivamente a las agresiones físicas o psicológicas por parte de un hombre. Lamentablemente, como venimos diciendo, la deriva de las políticas por la igualdad, hasta el momento, parecía seguir ese camino. Con ello no queremos restar importancia a la necesaria visibilización de la manifestación extrema de la violencia sistémica a la que las mujeres se encuentran sometidas y, en ese sentido, a la intervención del Estado poniendo medios para erradicar la violencia. No obstante, la inclusión del imaginario feminista o de la perspectiva de género en los usos sociales va más allá del reconocimiento de la víctima en el marco normativo, en tanto que las mujeres, día tras día, se erigen como esas supervivientes, como sujetos activos que se desarrollan a pesar de la violencia transversal del patriarcado, aunque no por ello lo hagan siempre de manera consciente.

Es de esta manera, reconociendo la agencia situacional y cotidiana de las supervivientes, como la práctica feminista puede activar de manera exponencial los recursos para el empoderamiento a través de sus relaciones de alianza (Núñez, 2011: 86). La generación de esos espacios seguros de alianza y comunicación, como hemos ejemplificado a través de RAMMAS, que se encuentran a medio camino entre lo privado y lo público, permiten la redefinición autónoma de la condición personal y, por tanto política, de las mujeres sin que ésta implique el abandono a su suerte y la ruptura radical de sus modos de vida y la de sus allegados tras la denuncia.

\section{Referencias bibliográficas}

Butler, Judith (1990). Gender Trouble. London: Routledge.

Butler, Judith (2005). Giving Account of Oneself. New York: Fordham University Press.

De Miguel, Ana. (1995). "Los feminismos a través de la historia", en Amorós, C. (ed.), Diezpalabras clave de feminismo. Estella: Verbo Divino, 93-126. 
Fernández Romero, Diana et al. (2011). "Nuevos espacios de comunicación, relación y activismo en la era digital: la Red como oportunidad para el feminismo". ASPARKÍA. Investigació Feminista, 22: 61-72.

Gámez Fuentes, María José (2012). "Sobre los modos de visibilización mediático-política de la violencia de género en España: consideraciones críticas para su reformulación". OBETS. Revista de Ciencias Sociales, 7 (2), 185-213.

Gámez Fuentes, María José (2015). "Feminisms and the 15M Movement in Spain: Between Frames of Recognition and Contexts of Action". Social Movement Studies, 14 (5).

Gámez Fuentes, María José y Sonia Núñez Puente (2013). “Medios, ética y violencia de género: más allá de la victimización”. ASP ARKÍA. Investigació Feminista, 24, 145-160.

Gimeno, Beatriz (2014). "El silencio político alienta la violencia machista”. Pikara Magazine. Recuperado (enero 2015) de http://www.pikaramagazine.com/2014/09/el-silencio-politicoalienta-la-violencia-machista/.

Núñez Puente, Sonia (2011). "Activismo y colectivos en red: praxis feminista 'online' y violencia de género". ASP AKÍA. Investigació Feminista, 22: 85-98.

Núñez Puente, Sonia et al. (2013). "La construcción del sujeto víctima de violencia de género en YouTube como acto performativo: estudio del activismo online desde el análisis multimodal". Cuadernos Kóre. Revista de Historia y Pensamiento de Género, 8 (Primavera-Verano): 179199.

Núñez Puente, Sonia et al. (2015). “Online activism and subject construction of the victim of gender-based violence on Spanish YouTube channels: Multimodal analysis and performativity". European Journal of Women Studies, 22 (1).

Oliver, Kelly. 2004. "Witnessing and Testimony". Parallax, 10(1): 7988. 



\title{
Lo iconográfico hace herida. Estereotipos en plataformas de minijuegos para chicas
}

\author{
Rocío de la Maya Retamar \\ Universidad de Málaga \\ Perfil de Google ${ }^{114}$ y código de Orcid ${ }^{115}$
}

\section{Introducción}

QUÉ relación tiene un pony, peinar a un gato, un mundo lleno de corazones, un salón de belleza, hacer una tarta y una Barbie bebé el día de Halloween con ser una mujer? ¿La superficialidad y la estereotipia nacen o se hacen?

En las siguientes líneas nos proponemos realizar una reflexión del mundo contemporáneo y su perpetuación de roles a través de una de las múltiples plataformas de minijuegos destinados a niñas que inundan la red: juegosdechicas.com y el posterior análisis de las prioridades en una educación banalizada y consumista a través de la cual las tendencias a repetir patrones son claramente evidentes: por ejemplo el mundo de la mujer en la literatura. Existe en nuestra

\footnotetext{
${ }^{114} \mathrm{http}: / /$ scholar.google.es/citations?user=Lz2ZwqsAAAAJ\&hl=es

${ }^{115}$ http://orcid.org/0000-0003-4416-9177
} 
sociedad contemporánea un desapego hacia la cultura y la formación, un jactarse de la ignorancia que, fagocitado por estas plataformas, nos darán un resultado de futuro que, al menos desde la perspectiva actual, resulta claramente desolador.

\section{Hacia un perfil de los videojugadores españoles: algunos datos}

Según datos de la Asociación Española de Videojuegos (AEVI), el sector del videojuego en España facturó en 2013 la cifra de 762 millones de euros, lo que la consolida como primera industria de ocio audiovisual e interactivo de nuestro país. Buena parte de ese éxito y de las halagüeñas perspectivas a medio plazo, se deben a la madurez de los "modelos de distribución online, la multiplicación de plataformas o la progresiva utilización de los videojuegos como herramientas tecnológicas en múltiples áreas". (AEVI, 2013: 13).

España se sitúa en el top ten del mundo y entre los primeros cinco países europeos en cuanto a número de videojugadores: 19,5 millones, de los cuales 6 millones $-\mathrm{y}$ en esto solo nos supera el mercado chino- se denominan "jugadores multipantalla", esto es, juegan en las cuatro pantallas: ordenador personal, móviles, tabletas y consolas (portátiles o conectadas al televisor). Es decir, casi la mitad de los españoles se consideran videojugadores. En cuanto a tipos de juegos, los juegos sociales o social gaming representan el segmento más grande de mercado en nuestro país, seguidos de los juegos para TV/consola y los juegos para móviles. ${ }^{116}$

\footnotetext{
${ }^{116}$ Datos facilitados por la consultora especializada en videojuegos Newzoo en su informe sobre el mercado español de videojuegos. Ver referencia en bibliografía.
} 


\section{ALCANCE DE LOS VIDEOJUEGOS EN ESPAÑA: POR DISPOSITIVO UTILIZADO PARA JUGAR}

(Base: Población de 6-64 años)

\begin{tabular}{|l|l|}
\hline$\%$ juega en consolas & $23 \%$ \\
\hline$\%$ juega en consolas portátiles & $12 \%$ \\
\hline$\%$ juega en el ordenador & $24 \%$ \\
\hline$\%$ juega en el móvil & $20 \%$ \\
\hline$\%$ juega en tabletas & $11 \%$ \\
\hline
\end{tabular}

\begin{tabular}{|l|c|}
\hline \# juega en consolas & $8 \mathrm{~m}$ \\
\hline \# juega en consolas portátiles & $4 \mathrm{~m}$ \\
\hline \# juega en el ordenador & $9 \mathrm{~m}$ \\
\hline \# juega en el móvil & $7 \mathrm{~m}$ \\
\hline \# juega en tabletas & $4 \mathrm{~m}$ \\
\hline
\end{tabular}

Pero, ¿qué género o perfil nos encontramos tras esas cifras? ¿Qué papel ocupa la mujer como consumidora de videojuegos? Pues probablemente tiene un papel mucho más relevante del que podríamos suponer a priori a tenor de los datos que se extraen del estudio que refleja la tabla siguiente:

\section{PERFIL DEL VIDEOJUGADOR/A EN ESPAÑA}

(Base: Población de 6-64 años)

\begin{tabular}{|c|c|c|c|}
\hline \% hombres & $\mathbf{5 2 \%}$ & $\mathbf{0}$ mujeres & $\mathbf{4 8 \%}$ \\
\hline Hombre 6-10 & $7 \%$ & Mujer 6-10 & $6 \%$ \\
\hline Hombre 11-14 & $5 \%$ & Mujer 11-14 & $5 \%$ \\
\hline Hombre 15-24 & $11 \%$ & Mujer 15-24 & $9 \%$ \\
\hline Hombre 25-34 & $13 \%$ & Mujer 25-34 & $11 \%$ \\
\hline Hombre 35-44 & $9 \%$ & Mujer 35-44 & $9 \%$ \\
\hline Hombre 45-64 & $7 \%$ & Mujer 45-64 & $8 \%$ \\
\hline
\end{tabular}


Fuente: Elaboración propia a partir de los datos de GameTrack (Ipsos MediaCT), Quarter 3, 2014.

El aumento de mujeres que juegan a videojuegos no es solo propio de España, sino que representa una constante a nivel mundial gracias a la variedad de plataformas anteriormente apuntadas que han permitido una mayor oferta de estilos con la consiguiente incorporación de diferentes segmentos de mercado. Sin embargo, este papel activo como consumidora no encuentra un paralelismo del lado de la producción y, en consecuencia, de la representación, ya que en 2013 solo el 6\% de videojuegos estuvieron protagonizados por mujeres. (Cano, 2014).

Nuestra reflexión y análisis se centra en un ejemplo de plataforma online -Juegosdechicaas.com - que ofrece juegos, normalmente gratuitos $^{117}$, destinados a chicas de entre 6 y 15 años, e incluso un poco mayores. Si hacemos una extrapolación de los datos aportados en las tablas, estaríamos hablando de que serían aproximadamente 1 millón las videojugadoras potenciales que se ajustarían al perfil al que se dirige la página.

\section{Estereotipos analógicos que se perpetúan digitalmente}

Mientras en el mundo analógico se debate una y otra vez sobre las premisas de igualdad entre los géneros, la tendencia en el mundo lúdico de internet se dirige hacia una reafirmación de clichés que creíamos aparentemente superados. No existen minijuegos de chicos: existen juegos de disparos, de coches, de aventuras, etc. Sin embargo, los minijuegos destinados a chicas que proliferan en la red constituyen un tema aparte, y por ello merecen ser sacados de

${ }^{117}$ El modelo de negocio de estos videojuegos suele basarse en la publicidad, es decir, el videojuego incluye publicidad por la que el desarrollador/propietario del juego obtiene ingresos. Una variedad de los videojuegos basados en publicidad son los llamados Around-game advertising, en los que la publicidad rodea al juego, pudiendo aparecer antes o después de jugar, y que es muy común en la clase de juegos online a los que nos referimos en este capítulo (DEV, 2014: 11). 
contexto, focalizados hacia esa nueva jugadora que antes no participaba como agente activo en los videojuegos.

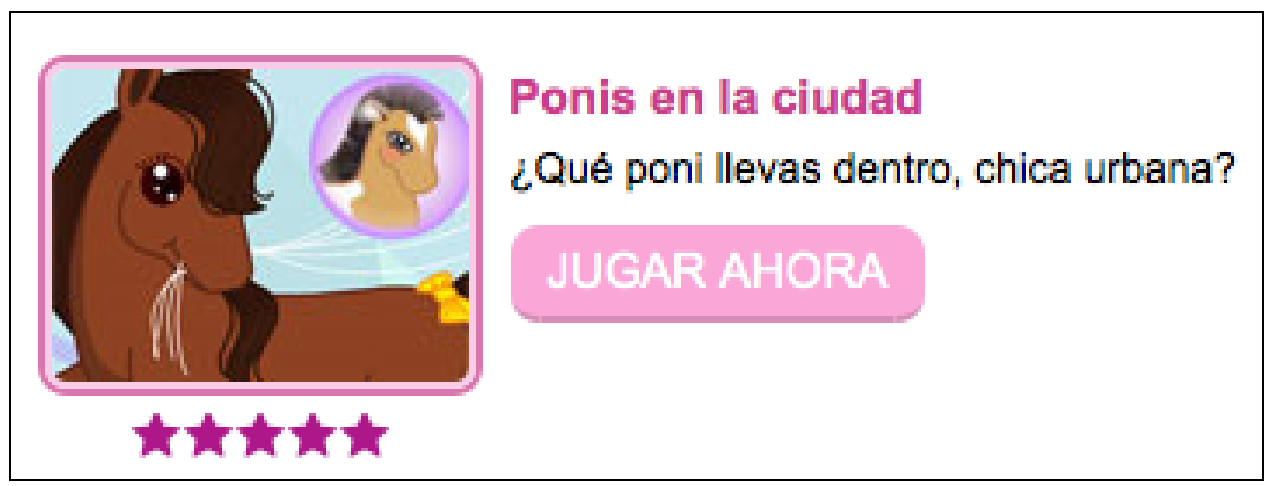

Ponis en la ciudad, uno de los juegos disponibles en juegosdechicas.com dentro de la categoría Juegos de diversión. Preguntas y tests.

Enrique J. Díez y otros, tras una revisión del estado de la investigación sobre el tema, presentaron en su estudio sobre los videojuegos desde la perspectiva de género los tres tipos de modelos de personajes femeninos más perpetuados y representativos en los videojuegos actuales que cuentan con un mayor número de ventas (Díez y otro, 2004: 4):

a) El modelo masoquista: retrata a un tipo de mujeres pasivas y sumisas que, o bien son víctimas que han de ser rescatadas, o aparecen en segundo plano como complemento del hombre y cuya función, por tanto, está al servicio del hombre. Transmiten una imagen frágil y dolorosa; son pacientes y aguantan, pero viven y mueren en función de los hombres. 


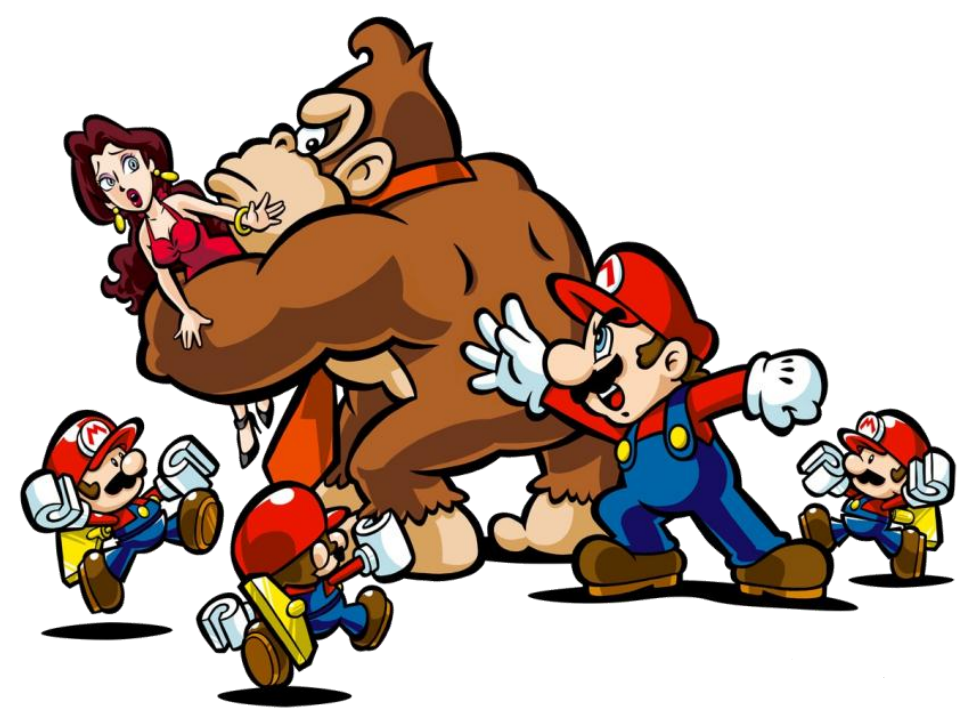

Pauline, cuyo amor se disputaban Donkey Kong $\bigcirc$ y Mario Bros ${ }^{\complement}$, como ejemplo del modelo masoquista de mujer pasiva y sumisa en los videojuegos que espera ser rescatada.

Es decir, no es más que una revisión del modelo de "damisela en apuros" que tuvo su época dorada en los videojuegos de los años 80 y principios de los 90. De hecho y como apunta Luis Cano en su artículo, no hay que olvidar que el primer diálogo de una mujer en un vieojuego fue 'Help!' (¡Ayuda!) pronunciado en 1981 en Donkey Kong.

b) El modelo sádico: en este modelo, las mujeres reproducen el 'arquetipo viril' con actitudes presuntamente masculinas pero con una clara potenciación de los atributos físicos exageradamente femeninos: el personaje de Lara Croft en la serie Tom Raider, una de las franquicias más importantes de la historia de los videojuegos, encontraríamos un claro ejemplo de este tipo o, más recientemente en el personaje de la buja Bayonetta en el juego Bayonetta 2. Los autores apuntan sin embargo que incluso en estos casos de personajes femeninos que tienen una función más activa en el desarrollo de la historia, su función última seguiría estando al servicio de los hombres. 

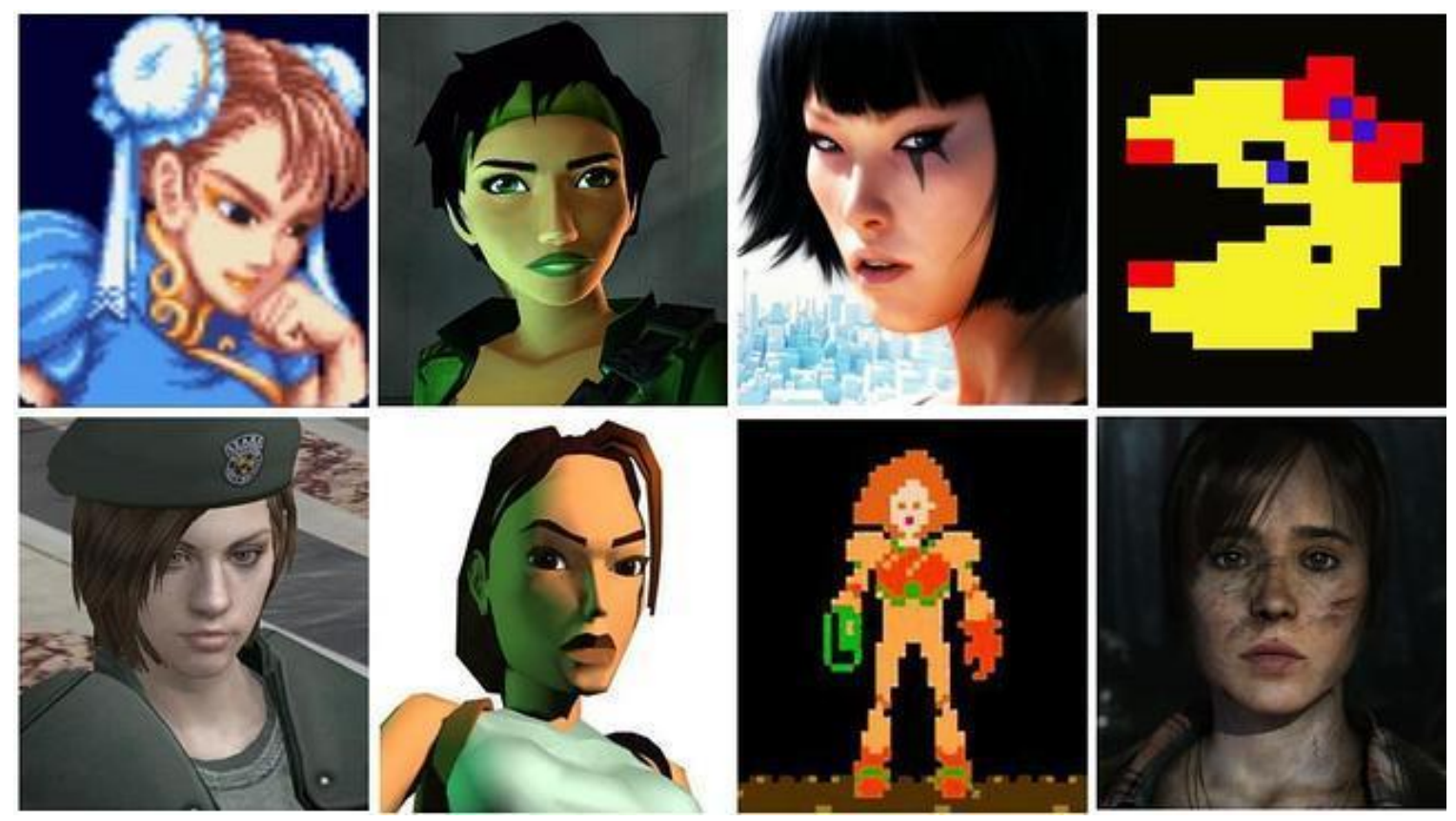

Diferentes prototipos de mujeres en videojuegos a lo largo de la historia. Fuente: Cano, 2014. ${ }^{118}$

c) El modelo 'barbie': en este caso nos encontramos con "mujeres consumistas, superficiales, decorativas, centradas en la imagen y la apariencia (Bratz, Barbie)" que reproducen "los estereotipos más tradicionales sobre las mujeres". Esta categoría encontraría su principal acomodo en los denominados 'videojuegos rosa' que surgieron para atraer a las chicas al mercado de los videojuegos. ${ }^{119}$

${ }^{118}$ Arriba: Chun li (Street Fighter II), Jade (Beyond Good and Evi), Faith Connors (Mirror's Edge), Ms PacMan. Abajo: Jill Valentine (Resident Evii), Lara Croft (Tomb Raider), Samus Aran (Metroid), Jodie Holmes (Beyond: Two Souls).

${ }^{119} \mathrm{Al}$ evaluar estos modelos o estereotipos no hemos podido evitar advertir ciertos paralelismos con el llamado test de Bechdel, un sistema popularizado por la autora norteamericana de cómics Alison Bechdel en una de sus tiras cómicas llamada "The Rule". El test, aplicable fundamentalmente a películas, se utiliza para evaluar la brecha de género en el cine, poniendo de manifiesto la poca presencia de mujeres o su irrelevancia en el desarrollo de la narrativa. Así, una película pasaría el test si consigue superar tres requisitos: 1. Que en ella aparezcan al menos dos personajes femeninos; 2. Que dichos personajes dialoguen entre sí en algún momento de la historia; y 3. Que en la conversación que mantengan entre ellas se aborde algún tema que no tenga que ver con un 
Estas categorías nos llevan a plantearnos una serie de cuestiones: ¿se sienten las videojugadoras representadas en las protagonistas tipo Lara Croft (mujer objeto activa), o tipo "damisela en apuros" como la Pauline en las garras de Donkey Kong, o la aburrida Farah de El principe de Persia que solo aparecía en escenas no jugables? ¿Será que el papel de la mujer en los videojuegos no es jugable y si lo es, es desde el punto de vista masculino? ¿De verdad es divertido constreñimos a peinar ponys y a hacer cup cakes como si no hubiera un mañana?

\section{Repetición de patrones sexistas y analogías con la literatura clásica}

La feminista estadounidense Anita Sarkeesian, que lleva años denunciando el sexismo en la cultura popular desde su web Feminist Frequency, mantiene que el machismo en los videojuegos no se ha superado pese a los avances de los últimos tiempos ya que, según denuncia, la clasificación de los videojuegos por edades no impide la repetición de patrones sexistas que tienen profundas raíces en la literatura clásica.

Es muy probable que la cuestión sea la misma de siempre: si quienes guionizan, diseñan y desarrollan el juego o la idea, tienden a una identidad o una iconografía propia y a mostrarlo de la manera más afín posible a sí mismos; es decir, si es diseñado, pensado y realizado desde el punto de vista de la masculinidad, está claro que atenderá a todas esas premisas. Basta con analizar el arte y la literatura en general. $^{120}$

hombre. Resulta sorprendente la cantidad de películas que no consiguen superar estas tres simples reglas y mucho nos tememos que en caso de aplicarlo a los videojuegos el resultado sería similar.

${ }^{120} \mathrm{El}$ déficit de mujeres trabajando en la industria de videojuegos es muy notable: en la actualidad supone en torno a un $12 \%$ del total de trabajadores, lo que supone un avance si tenemos en cuenta que en 1989 solo eran el 3\%. Citado por L. Cano, 2014. 
Pero, ¿qué sucede si el que diseña los juegos desde esa masculinidad se ve obligado a diseñar juegos para chicas intencionadamente? Lo primero que salta a la vista es que todo es rosa.

Analicemos con detenimiento los minijuegos de esta página:

Se resaltan por encima de otras las categorías: juegos de vestir y juegos de cocinar, que no se alejan mucho al modelo de la Perfecta casada de Fray Luis de León (1583: 66): "Porque no se entiende que, si madrugada la casada, ha de ser para que, rodeada de botecillos y arquillas, como hacen algunas, se esté sentada tres horas afilando la ceja, y pintando la cara, y negociando con su espejo que mienta y la llame hermosa".

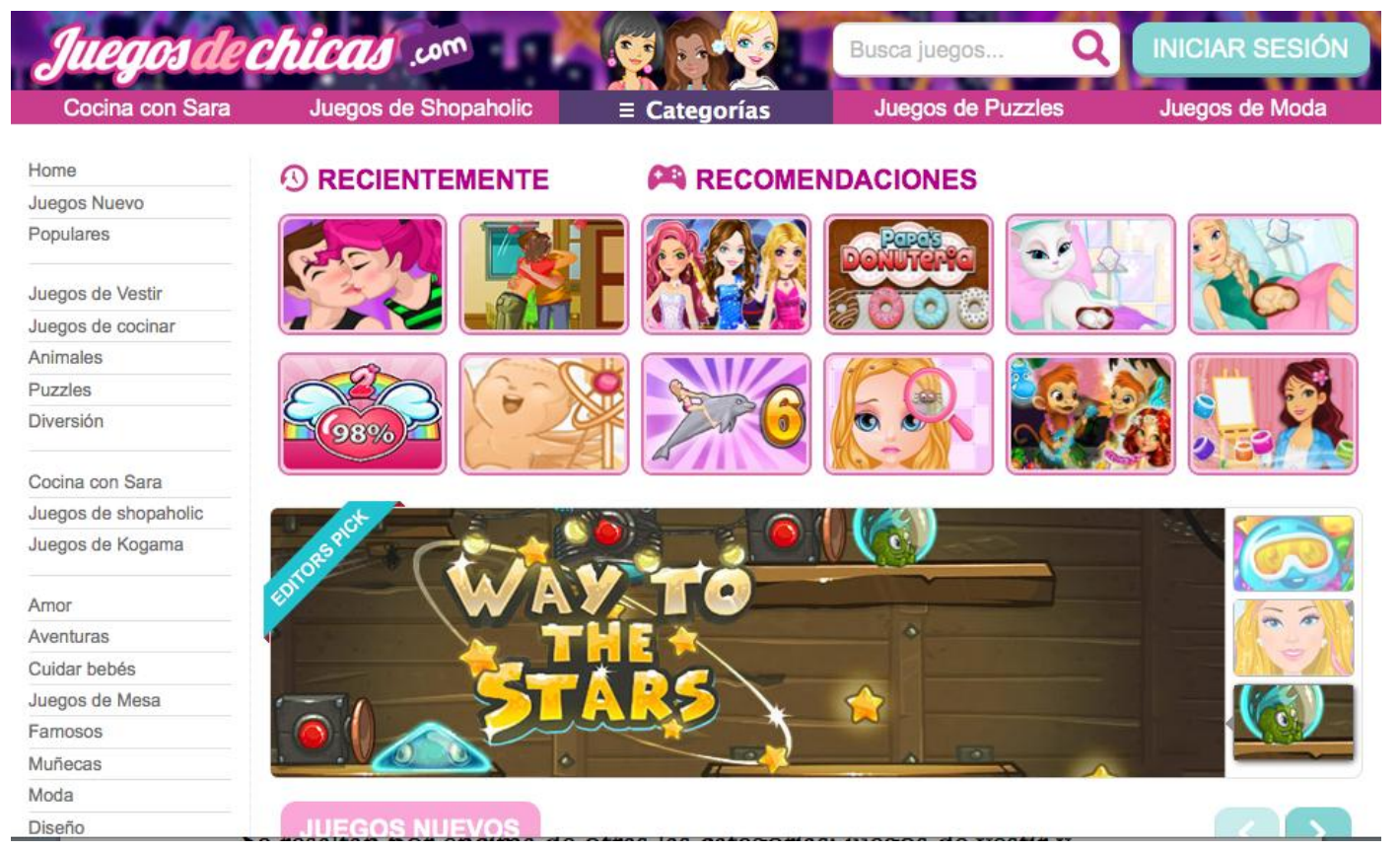

Interfaz principal de la plataforma juegosdechicas.com

O al fragmento que destacamos de Benito Pérez Galdós: “Lo mismo funcionaba en la cocina que en el escritorio, y acabadita de poner la enorme sartén de migas para la cena o el calderón de patatas, pasaba a la tienda a que su marido la enterase de las facturas que acababa de recibir o de los avisos de letras. Cuidaba principalmente de que sus niñas no estuviesen ociosas. Las más pequeñas y los varoncitos iban a 
la escuela; las mayores trabajaban en el gabinete de la casa, ayudando a su madre en el repaso de la ropa, o en acomodar al cuerpo de los varones las prendas desechadas del padre. Alguna de ellas se daba maña para planchar; solían también lavar en el gran artesón de la cocina, y zurcir y echar un remiendo. Pero en lo que mayormente sobresalían todas era en el arte de arreglar sus propios perendengues." Pérez Galdós, 1887: 72).

O a la famosa novela decimonónica de Juan Valera en la que describe a Juanita la Larga como: "Lo más admirable era que Juana, sobre ser la más sabia cocinera y repostera del lugar, era también su primera modista" (Valera, 1895: 481). Curiosamente los mismos principios (menos el pony).

Hay, además, un contenido superfluo y consumista del propio contenido que impone la femineidad. Ahora en el S. XXI no solo seguimos fagocitando estos roles sino que además añadimos a estos valores los de lo superficial y los del consumo. Como bien decía Walter Benjamin: "Al entrar el sistema de aparatos en representación del hombre, la autoenajenación humana ha sido aprovechada de una manera extremamente productiva" (Benjamin, 1936: 73). En ejemplos como: la secuela de "Adictas a las compras" en sus versiones Hollywood, Hawai, París o "Cómo vestirse para salir con un famoso".

Pero volvamos a la página para conocer la cantidad de juegos que se agrupan en torno a las diferentes categorías y así saber si podemos sacar una conclusión. Encontramos, además, en esta página: 
Número de juegos por categorías en la página web juegosdechicas.com

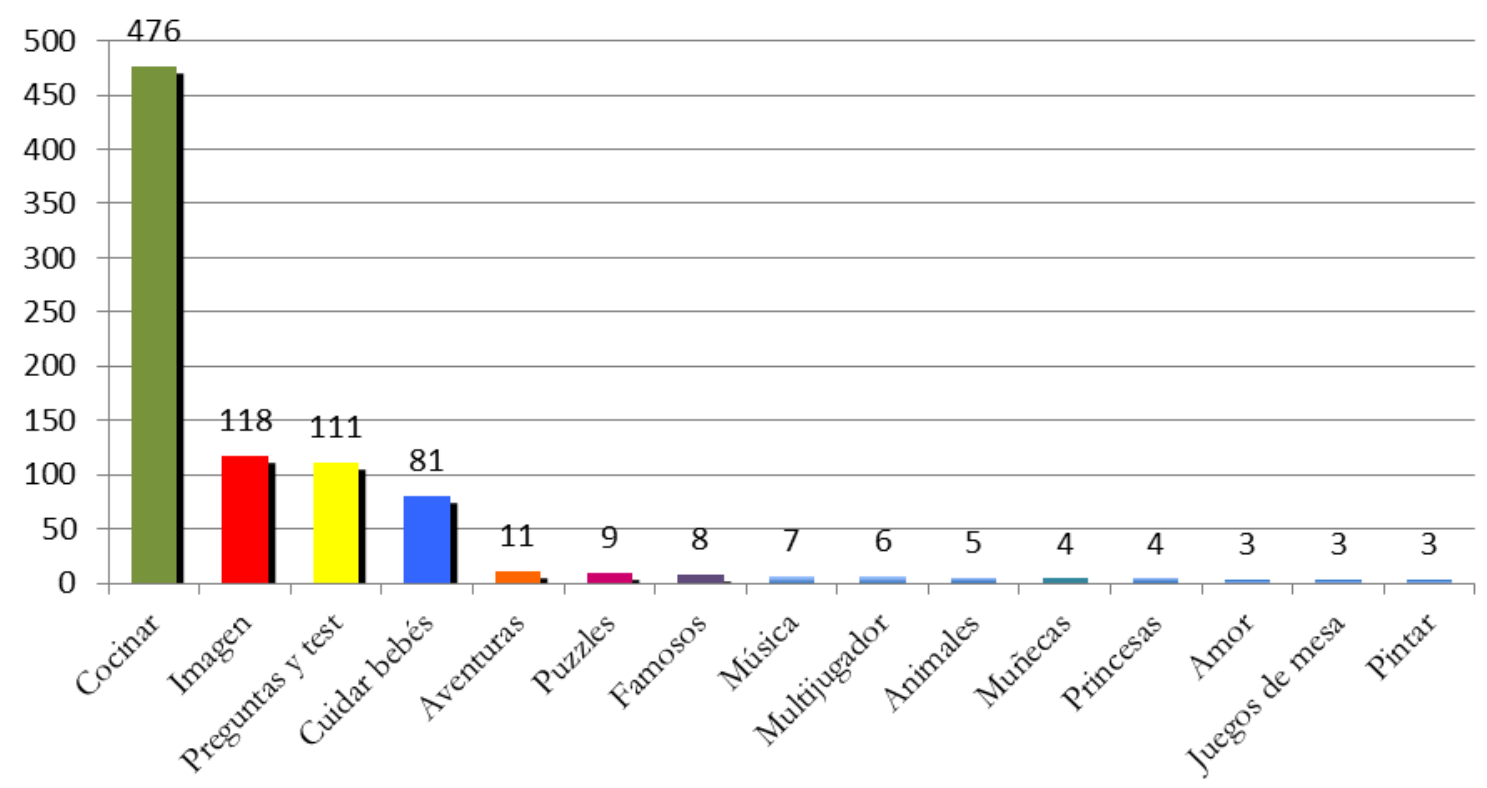

Fuente: elaboración propia

Agrupamos en torno a la categoría "Imagen" todos aquellos juegos que tienen que ver con la moda, el vestir, el diseño o el estilismo. Según nuestro gráfico, los juegos de cocina destacan sobre el resto representando un 56\% del total, le seguirían con un 13,9\% los relacionados con la imagen, un 13\% los de preguntas y test, el 10\% de cuidar bebés, entre los más numerosos. La pregunta sería si es una demanda en función de los más jugados o es una imposición de roles condenada a repetirse.

Los juegos de preguntas y test, que representan el 13\% de los juegos de la página, vuelven a incidir en las propias categorías que hemos descrito anteriormente, es decir, que ninguno es de cultura general o de capacidad intelectual o de algo que ligeramente se salga de la línea. Tenemos por ejemplo: cómo sería la casa de tus sueños, cómo es tu novio ideal, cuál es tu belleza, qué tipo de princesa eres hoy, etc. 
Número de juegos por categorías en el apartado preguntas y test

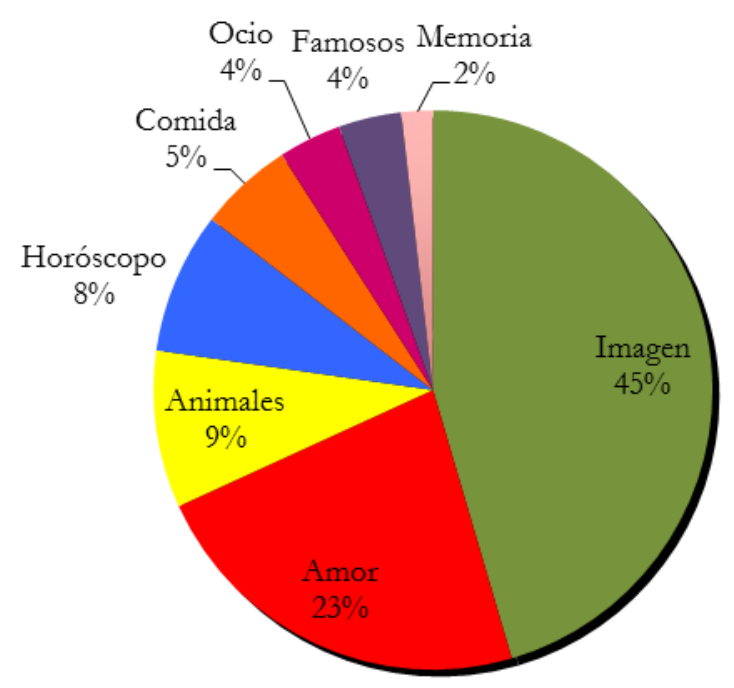

Fuente: elaboración propia sobre un total de 111 juegos

De alguna manera no puede una escapar en esta página de una espiral de infantilismo mezclado con una superficialidad que incita al consumo. Los rangos de edad de los juegos no están aclarados, si bien se deduce que estarían indicados para niñas de entre 6 a 15 años, una edad en la que la educación es fundamental y en la que resultan llamativos juegos del tipo: 


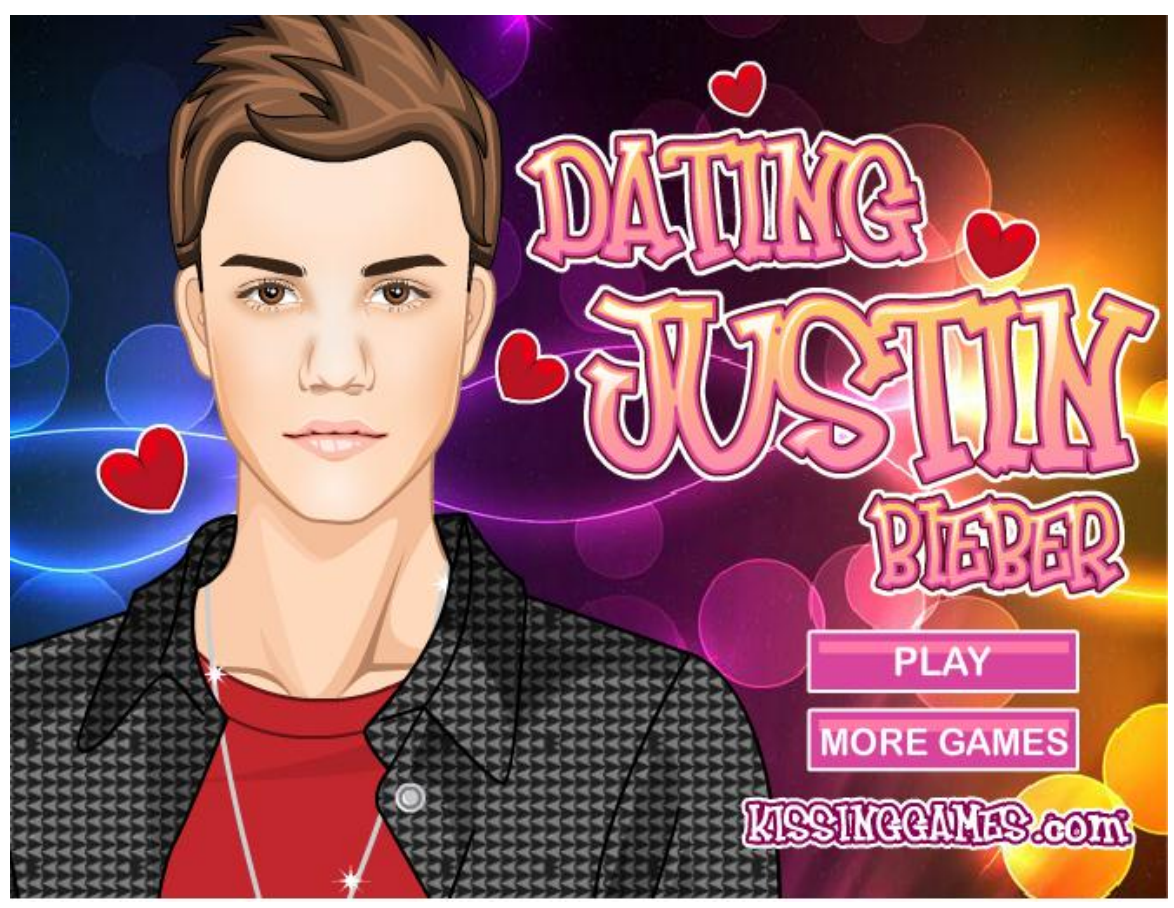

Fuente: web de juegos para chicas kissinggames.com ${ }^{121}$

La cita perfecta para quedar con Justin Bieber, ¿de verdad es a esto lo que nos interesa que las nuevas generaciones de chicas dediquen su tiempo? ¿De verdad a ellas les interesa esta banalidad? Lo interesante es que en programas de televisión también se mantienen estos formatos, que no son un producto solo nacional, sino también internacional: Gandía Shore por ejemplo, es una adaptación de un famoso programa de la MTV Jersey Shore. Programas en los que se realzan prioridades superficiales, con las que se puede estar o no de acuerdo y pueden parecer o no divertidas, pero desde luego miradas desde un crisol y un cedazo propio, desde una base sólida, desde un horizonte previamente asentado; ya lo dijo el fabulista griego Fedro: el hombre instruido lleva en si mismo sus riquezas. No puede ser la única referencia si no queremos que alcance límites de no retorno en una sociedad conformista y primitiva.

${ }^{121}$ Este juego está tomado de otra página web: kissinggames.com que mantiene los mismos formatos y contenidos que la que estamos analizando. 


\section{A modo de reflexión final}

Asistimos a una banalización de la sociedad en términos generales, que parte de un desinterés y una jactancia por la propia incultura que nos lleva a situaciones de atraso de convicciones y de conquistas propias de lo que significan los roles (que es el tema que nos ocupa). La revisión de la femineidad y la estereotipia que se arrastra con ella no pasa por su mejor momento si atendemos a cómo educamos o a qué prioridades damos nuestro beneplácito. Si no formamos en un criterio sólido, en una base desde la que podamos luego construir o destruir nuestras identidades con rigor, no tendremos más remedio que estar condenados a repetir el pasado en sus formas más arcaicas. No se trata de condenar ciertas preferencias que uno tenga con respecto a su identidad, se trata de saber elegirla con un criterio formado, no dirigido, no sometido por el desconocimiento.

Decía Walter Benjamin en su Libro de los pasajes que "las calles son la morada del colectivo". Si quisiésemos hacer una pequeña analogía entre el flâneur parisino por las calles y el "ciberflâneur" que bien podría ser el internauta asiduo por las calles de la red donde podríamos hallar ese colectivo actual, nos daríamos cuenta de que existen calles anchas, avenidas de juegos como zylom.com o bigfishgames.com, nos daríamos cuenta de que existen plazas como juegos interactivos entre jugadores distintos y nos daríamos cuenta de que existen callejones por los que casi no se transita, que están dando una oferta de víveres para ideas cadáver, para demandas inexistentes. Aquí se crea la demanda, por tanto se crea la preferencia, se presume la prioridad y las conclusiones son claramente insatisfactorias: el rosa chillón de lo femenino como escaparate para un contenido sin sustancia jugable que es de lo que se trata.

La necesidad de sensación que exige la sociedad contemporánea no pasa por la reiteración de roles, pasa por la creatividad basada en referentes reales, actuales. Aquí es más interesante salirse de los lugares comunes y trazar nuevas líneas hacia lo ignoto: si tenemos un soporte diferente busquemos nuevos discursos. 


\section{Referencias bibliográficas}

AEVI (Asociación Española del Videojuego) (2013). “Anuario de la industria del videojuego". Recuperado (enero 2015) de http://www.aevi.org.es/anuario2013/

Benjamin, W. La obra de arte en la época de su reproductibilidad técnica. México: Ítaca editores, 2003.

Cano, L. "Superando el papel secundario de la mujer en los videojuegos", Diario Abc, 28.10.2014. Recuperado (enero 2015) de http://www.abc.es/tecnologia/videojuegos/20141025/abci-mujeresvideojuegos-sexismo-201410241511.html

DEV (Asociación Española de Empresas Productoras y

Desarrolladoras de Videojuegos y Software de Entretenimiento) (2014). "Libro blanco del desarrollo español de los videojuegos". Recuperado (enero 2015) de http://www.dev.org.es/es/publicaciones/libro-blanco-dev

Díez Gutiérrez, E.J., Fontal Merillas, O. y Blanco Jorrín, D. (2004). "Los videojuegos desde la perspectiva de género: roles y estereotipos". Recuperado (enero 2015) de http://ardilladigital.com/DOCUMENTOS/TECNOLOGIA\%20E DUCATIVA/TICs/T8\%20VIDEOJUEGOS/VJ\%20GENERO.pdf

Fray Luis de León (1583). La perfecta casada. Alicante: Biblioteca Virtual Miguel de Cervantes, 2003. Edición digital basada en la $11^{\mathrm{a}}$ ed., Madrid, Espasa Calpe, 1980.

Game'Track (IFSE/Ipsos MediaCT) (2014). “Game'Track Digest: Quarter 3 2014". Recuperado (enero 2015) de http://isfe.eu/sites/isfe.eu/files/attachments/gametrack_european_ digest_q3-14_0.pdf

ISFE/Ipsos MediaCT (2014). “Game'Track European Digest Quarter 3 2014". Recuperado (enero 2015) de

http://www.isfe.eu/sites/isfe.eu/files/attachments/gametrack europ ean digest q3-14.pdf

Newzoo (2014), "Infographic: The Spanish Game Market".

Recuperado (enero 2015) de 
http://www.newzoo.com/infographics/infographic-spanish-gamesmarket/

Pérez Galdós, B. Fortunata y Jacinta: (dos historias de casadas). Alicante : Biblioteca Virtual Miguel de Cervantes, 2001. Edición digital basada en la edición de Madrid, Imprenta de La Guirnalda, 1887.

Valera, J. Obras completas. Madrid: Aguilar Ediciones, 1934. 


\title{
Ver la violencia, comunicar la equidad. Diagnóstico y Práctica Docente
}

\author{
$\mathbf{M}^{\mathrm{a}}$ Teresa Vera Balanza \\ Universidad de Málaga
}

\section{Introducción}

— $\mathrm{N}$ el programa de televisión MasterChef Junior del pasado 7 de enero, durante uno de los retos, en el que los participantes cocinaban al aire libre para sus abuelos y abuelas, el cocinero Pepe Rodríguez les aconsejaba a todos los concursantes comenzar a recoger los utensilios y dejar limpia la mesa de la prueba. Uno de los participantes, el joven Víctor de 12 años, dijo a sus compañeras: 'Madre mía, estoy rodeado de chicas... las chicas ya sabéis limpiar, genéticamente.' Las chicas de su equipo contestaron al unísono: ‘¡Eh, eh, eh!... cuidadito con lo que dices'.

El concursante fue reprendido por el juez que le impuso que limpiara solo la cocina entera. Luego, aseguraba el pequeño: 'No quería decir eso, yo quería decir que las chicas saben limpiar mejor que los chicos, que para mi punto de vista, es así.' 
El gesto del programa fue aplaudido por los fans en Twitter. Nosotros nos planteamos el papel de la televisión como caja de reverberación de las prácticas cotidianas. Nosotras nos preguntamos sobre las conductas asimiladas de los jóvenes; lo que el pequeño Víctor llama su "punto de vista". Desde luego, estos sujetos en plena etapa formativa, que alardean de sus destrezas culinarias para el regocijo de sus progenitores y acarician el estrellato televisivo, son muestra y ejemplo, y sus puntos de vista tienen una importantísima relevancia en el día a día.

Qué duda cabe que saben moverse en la narrativa televisiva; qué duda cabe que lo que hacen ellos tiene una función prescriptora para sus iguales; qué duda cabe del potencial del canal, de sus actantes y de sus discursos.

Por hechos como estos que son indicios es por lo que entendemos que la televisión tiene una particular funcionalidad en el abordaje de la violencia machista en particular y en la perpetuación y/o en la crítica de las conductas sexistas en general. Ese ha sido el objetivo del Observatorio andaluz de violencia machista en los medios audiovisuales (ObVio) ${ }^{122}$ y esa también es la propuesta formativa trasversal que desarrollamos en la docencia universitaria para sensibilizar, concienciar y actuar en pro de la equidad por parte de quienes serán futuros y futuras profesionales de los medios. Si ellos no tienen el conocimiento, las herramientas profesionales y el bagaje teórico difícilmente podrán contribuir a la generación de mensajes igualitarios para una ciudadanía plural.

\section{Actitudes de la juventud universitaria ante la igualdad y la violencia machista}

En 2011 la Universidad de Málaga participó en el estudio nacional La juventud universitaria ante la igualdad y la violencia de género ${ }^{123}$, una

\footnotetext{
122 http:/ / obvio.uma.es

${ }^{123}$ http://www.msssi.gob.es/ssi/violenciaGenero/publicaciones/estudiosinvesti gaciones/PDFS/Juventud_Universitaria.pdf 24.01.2015
} 
investigación liderada por la Unidad de Psicología Preventiva de la Universidad Complutense de Madrid y la Delegación del Gobierno para la Violencia de Género del Ministerio de Sanidad, Servicios Sociales e Igualdad. La investigación seguía a otra realizada en centros de Secundaria y trataba de establecer el papel crucial que la educación superior puede y debe desempeñar en la construcción de la igualdad y la prevención de violencia de género. Se entendía que era necesario destacar el cambio generacional desde la educación y la formación especializada como herramientas fundamentales para conseguirlo. Luego, el incremento de los casos de violencia entre la población más joven y los mecanismos renovados de acoso y control mediante dispositivos móviles corroboraba la importancia de trabajar sobre este colectivo en general. Así nuestro alumnado, el de diez universidades públicas y dos privadas, se convertían a la vez en sujetos de estudio y en grupo prescriptor del resto de sus coetáneos. A la Universidad no solo se le exige que sea la casa del conocimiento y de la formación superior, que ponga en práctica los valores de la racionalidad científica, de la igualdad, la objetividad y la ecuanimidad; que contrarreste el dogma y el prejuicio.

La investigación tuvo una primera fase cuantitativa sustentada sobre un cuestionario distribuido a más de 3000 estudiantes de los que el $52 \%$ correspondían a los del área de las Ciencias Sociales y Jurídicas, precisamente aquellas - junto a la sanitaria- a las que la violencia de género le incumbe como profesionales. Los resultados del estudio cuantitativo explicitaba los fundamentos sobre los que luego se configuraban los discursos. Los resultados están publicados pero merece la pena recordar algunas conclusiones.

Además de las actividades propias de la vida estudiantil, las mayoritarias de la juventud universitaria se centraba en el uso de los medios: ver la televisión, navegar por internet y comunicarse con otras personas a través de internet. En estas prácticas, mujeres y hombres estaban prácticamente igualados, si bien las diferencias más acusadas se establecían entre las mujeres que se decantaban por estar por la familia (dedicando hasta 3 horas diarias) y los varones que preferían hacer deporte. Pese a que ambos apreciaban que se 
establecían relaciones equitativas entre ellos, de igual a igual, de respeto y confianza, las formas de socialización seguían siendo bastante diferentes. Del mismo modo, pervivían también la percepción de control, dureza emocional y autoestima en mayor medida entre los estudiantes de las titulaciones técnicas -donde el porcentaje de varones es mayor- y entre las de las Humanidades que mayoritariamente son mujeres. Pese a que era casi residual, 5-6\% la percepción de machismo para hombres y mujeres respectivamente, en un análisis más pormenorizado las actitudes se dejaron ver claramente.

Para observar el sexismo y la justificación de la violencia se aplicaron al total de la muestra dos escalas: la de sexismo ambivalente ASI Ambivalent Sexism Inventory ${ }^{124}$, y la escala de justificación del sexismo y la violencia ${ }^{125}$ de Díaz-Aguado y Martínez Arias.

La distribución de porcentajes de respuesta respecto al sexismo benevolente presentaba los siguientes resultados sobre las afirmaciones enunciadas:

\begin{tabular}{|l|r|r|}
\hline & Hombres & Mujeres \\
\hline $\begin{array}{l}\text { Aún cuando un hombre logre muchas cosas en } \\
\text { su vida, nunca podrá sentirse verdaderamente } \\
\text { completo a menos que tenga el amor de una } \\
\text { mujer. }\end{array}$ & 55,44 & 34,1 \\
\hline $\begin{array}{l}\text { En caso de una catástrofe, las mujeres deben } \\
\text { ser rescatadas necesariamente antes que los } \\
\text { hombres. }\end{array}$ & 44,85 & 25,37 \\
\hline
\end{tabular}

${ }^{124}$ Glick, P. y Fiske, S. T. (1996). The Ambivalent Sexism Inventory:

Differentiating Hostile and Benevolent Sexism. Journal of Personality and Social Psychology, 70, 491-512.

${ }^{125}$ Díaz-Aguado, M.J., Martínez, R., Martín,J., Carvajal,I., Peyro,M.J., Abril,V. (2010) Igualdad y prevención de laviolencia de género en la adolescencia. Madrid: Ministerio de Sanidad, Asuntos Sociales e Igualdad. 


\begin{tabular}{|l|r|r|}
\hline $\begin{array}{l}\text { Las personas no pueden ser verdaderamente } \\
\text { felices en sus vidas a menos que tengan pareja } \\
\text { del otro sexo. }\end{array}$ & 20,62 & 11,11 \\
\hline $\begin{array}{l}\text { Muchas mujeres se caracterizan por una pureza } \\
\text { que pocos hombres poseen. }\end{array}$ & 30,71 & 25,43 \\
\hline $\begin{array}{l}\text { Las mujeres deben ser queridas y protegidas } \\
\text { por los hombres }\end{array}$ & 52,07 & 40,05 \\
\hline $\begin{array}{l}\text { Todo hombre debe tener una mujer a quien } \\
\text { amar }\end{array}$ & 37,75 & 18,15 \\
\hline El hombre está incompleto sin la mujer. & 35,59 & 17,11 \\
\hline $\begin{array}{l}\text { Una buena mujer debería ser puesta en un } \\
\text { pedestal por su hombre. }\end{array}$ & 45,45 & 29,05 \\
\hline $\begin{array}{l}\text { Las mujeres, en comparación con los hombres, } \\
\text { tienden a tener una mayor sensibilidad moral. }\end{array}$ & 54,11 & 61,84 \\
\hline $\begin{array}{l}\text { Los hombres deberían estar dispuestos a } \\
\text { sacrificar su propio bienestar con el fin de } \\
\text { proveer seguridad económica a las mujeres. }\end{array}$ & 14,37 & 4,642 \\
\hline $\begin{array}{l}\text { Las mujeres, en comparación con los hombres, } \\
\text { tienden a tener un sentido más refinado de la } \\
\text { cultura y el buen gusto. }\end{array}$ & 32,37 & 20,90 \\
\hline
\end{tabular}

Tan solo el grupo de estudiantes universitarias se mostraba mayoritariamente de acuerdo era con respecto al ítem Las mujeres, en comparación con los hombres, tienden a tener una mayor sensibilidad moral, pero en conjunto, el porcentaje de asentimiento de los varones era del 45\% y de las mujeres el 39\%. Glick y Fiske se refieren a sexismo benévolo como aquel de actitudes más positivas de los hombres hacia las mujeres siempre y cuando se cumplan los roles tradicionales, esto es, un paternalismo protector y una idealización de las mujeres en tanto que el dominio se torna protección.

Los resultados que muestran el sexismo hostil son en general más elevados entre los varones pero no tan distanciados con respecto a las respuestas de las estudiantes. El sexismo hostil tiene como componentes un paternalismo dominador, una diferenciación competitiva entre géneros y una hostilidad heterosexual que entiende 
que las mujeres son peligrosas y manipuladoras, y se mide en función del grado de acuerdo con las siguientes enunciaciones.

\begin{tabular}{|l|l|l|}
\hline & Hombres & Mujeres \\
\hline $\begin{array}{l}\text { Con el pretexto de pedir “igualdad" muchas } \\
\text { mujeres buscan privilegios especiales, tales } \\
\text { como condiciones del trabajo que las } \\
\text { favorezcan a ellas sobre los hombres. }\end{array}$ & 47,46 & 39,55 \\
\hline $\begin{array}{l}\text { La mayoría de las mujeres interpreta } \\
\text { comentarios o conductas inocentes como } \\
\text { sexistas, es decir, como expresiones de } \\
\text { prejuicio o discriminación contra ellas. }\end{array}$ & 48,11 & 39,03 \\
\hline Las mujeres se ofenden muy fácilmente & 39,91 & 23,64 \\
\hline $\begin{array}{l}\text { En el fondo, las mujeres feministas pretenden } \\
\text { que la mujer tenga más poder que el hombre. }\end{array}$ & 48,74 & 34,79 \\
\hline $\begin{array}{l}\text { La mayoría de las mujeres no aprecia } \\
\text { completamente lo que los hombres hacen por } \\
\text { ellas. }\end{array}$ & 36,74 & 18 \\
\hline $\begin{array}{l}\text { Las mujeres intentan ganar poder controlando } \\
\text { a los hombres. }\end{array}$ & 35,88 & 20,05 \\
\hline $\begin{array}{l}\text { Las mujeres exageran los problemas que tienen } \\
\text { en el trabajo. }\end{array}$ & 24,62 & 9,38 \\
\hline $\begin{array}{l}\text { Una vez que una mujer logra que un hombre } \\
\text { se comprometa con ella, por lo general intenta } \\
\text { controlarlo estrechamente. }\end{array}$ & 35,92 & 14,78 \\
\hline $\begin{array}{l}\text { Cuando las mujeres son vencidas por los } \\
\text { hombres en una competencia justa, } \\
\text { generalmente ellas se quejan de haber sido } \\
\text { discriminadas. }\end{array}$ & 36,41 & 20,76 \\
\hline $\begin{array}{l}\text { Existen muchas mujeres que, para burlarse de } \\
\text { los hombres, primero se insinúan sexualmente } \\
\text { a ellos y luego rechazan los avances de éstos. }\end{array}$ & 46,13 & 33,23 \\
\hline $\begin{array}{l}\text { Las mujeres feministas están haciendo } \\
\text { demandas completamente irracionales a los } \\
\text { hombres. }\end{array}$ & 38,98 & 23,91 \\
\hline
\end{tabular}


La escala de justificación del sexismo y la violencia de Díaz-Aguado et al. vincula la justificación de la violencia o bien al mantenimiento de la familia patriarcal, consideración que tenía menos incidencia entre la juventud universitaria; o la justificación del sexismo y la violencia como reacción, factor que si que se apreciaba. Incluso la consideración de que el hombre que parece agresivo resulta más atractivo era sostenida por un $20 \%$ de los varones y casi por el $10 \%$ de las mujeres. Con todo, este abordaje trataba de ponderar el grado de evolución o permanencia de los estereotipos de género entre la juventud con enseñanza superior entendiendo que es este factor, el formativo/educativo, el que ha de contribuir decididamente al cambio social.

La juventud universitaria entrevistada también conocía situaciones de violencia tanto propias como próximas. Se enumeran hasta 12 situaciones de maltrato que se agrupan en abuso múltiple (agresión, obligación a mantener relaciones sexuales y difusión de mensajes,...) que oscilaban entre el 5 y el 10\% de las respuestas afirmativas de las estudiantes; y el abuso emocional: aislamiento (29,79\%), control $(28,04 \%)$ e insulto o ridiculización $(33,57 \%)$ cuya incidencia era bastante más acusada y que ahora ha sido plenamente corroborada por el CIS ${ }^{126}$. Los varones, sin embargo, reconocían estas situaciones en unos porcentajes sensiblemente menores: insultos en el 20,14\% de los casos, control en el 11,12\% y aislamiento en el 8,43\%. Además, reconocen que se trata de conductas reiteradas -con las chicas con las que salía y con las que salen- en el 11\% de los casos.

Ciertamente si hay un punto de luz en esta situación es en el reconocimiento abierto y explícito, en que el asunto al menos ya no se mantiene oculto y que se identifican las conductas y se muestran

${ }^{126}$ Percepción de la violencia de género por la adolescencia y la juventud. Autoría:

Delegación del Gobierno para la Violencia de Género. Informe realizado por Verónica de Miguel Luken (Universidad de Málaga). Madrid: Ministerio de Sanidad, Servicios Sociales e Igualdad. 2015

https://www.msssi.gob.es/ssi/violenciaGenero/publicaciones/estudiosinvestig aciones/PDFS/Percepcion_Social__VG_Adolesc_Juv.pdf 
como prácticas violentas o abusivas. Otra cosa es la argumentación, la justificación del hecho...

\section{E1 discurso colectivo. Los grupos de discusión como polifonía social}

Aprender de lo que se habla, lo que se dice en determinadas condiciones, se convierte en una clave social para esta investigación. La Facultad de Ciencias de la Comunicación de la Universidad de Málaga contribuyó particularmente a la dimensión cualitativa de la investigación con la conformación y desarrollo de dos grupos de discusión de mujeres y de hombres, estudiantes todos de los grados de Periodismo, y Comunicación Audiovisual. Si bien el propósito general era conocer la situación de la juventud respecto a la igualdad y la erradicación de la violencia de género, saber su formación específica e implementar la dimensión social de la Universidad, en el caso específico que nos ocupa, el debate se focalizó hacia aspectos más cercanos.

La dinámica del grupo de discusión opera conforme a un proceso en el que la conversación es provocada y regulada. Acorde a estas circunstancias y para clarificar las condiciones, se constituyeron grupos de varones y de mujeres moderados, cada uno de ellos, por expertos de su mismo sexo y de edad cercana a la media del grupo aunque con formación específica en estas materias. La función de moderación o dinamización es fundamental porque ha de establecer una relación asimétrica con el grupo - dirige, modera, da o retira la palabra- pero crea en torno a si una dinámica de aglutinamiento.

Reunimos pues un grupo de 7 varones de $3^{\circ}$ y $4^{\circ}$-finalizando casiestudios de Periodismo y Comunicación Audiovisual, con edades comprendidas entre los 20 y 30 años, lo que permitía que algunos ya tuvieran alguna(s) experiencia(s) de convivencia en pareja; estuvieron moderados por un investigador doctoral que realiza precisamente su Tesis sobre tratamiento informativo de la violencia de género ${ }^{127}$. El

\footnotetext{
${ }^{127}$ Ramos Ruiz, Anselmo (2007). Comunicación para el desarrollo social en la violencia de género. En Congreso Internacional Violencia de Género: Medidas y
} 
grupo de mujeres estaba compuesto por 6 estudiantes de Periodismo con edades comprendidas entre los 21 y 26 años y moderado por una periodista que, con un perfil totalmente profesional, estaba encargada de encaminar las discusiones hacia la faceta productiva de la información sobre violencia. Hemos identificado sus intervenciones conforme a la siguiente codificación.

\begin{tabular}{|l|l|l|l|l|}
\hline Sexo & Edad & Titulación & $\begin{array}{l}\text { Formación en } \\
\text { igualdad }\end{array}$ & Código \\
\hline Hombre & 20 & Periodismo & - & H1 \\
\hline Hombre & 30 & $\begin{array}{l}\text { Comunicación } \\
\text { Audiovisual }\end{array}$ & - & H2 \\
\hline Hombre & 23 & $\begin{array}{l}\text { Comunicación } \\
\text { Audiovisual }\end{array}$ & $\mathrm{Si}$ & $\mathrm{H} 3$ \\
\hline Hombre & 25 & Periodismo & - & $\mathrm{H} 4$ \\
\hline Hombre & 21 & $\begin{array}{l}\text { Comunicación } \\
\text { Audiovisual }\end{array}$ & - & $\mathrm{H} 5$ \\
\hline Hombre & 22 & $\begin{array}{l}\text { Comunicación } \\
\text { Audiovisual }\end{array}$ & - & $\mathrm{H} 6$ \\
\hline Hombre & 25 & $\begin{array}{l}\text { Comunicación } \\
\text { Audiovisual }\end{array}$ & - & $\mathrm{H} 7$ \\
\hline Mujer & 21 & Periodismo & - & M1 \\
\hline Mujer & 23 & Periodismo & $\mathrm{Si}$ & M2 \\
\hline Mujer & 21 & Periodismo & Si & M3 \\
\hline Mujer & 21 & Periodismo & Si & M4 \\
\hline Mujer & 26 & Periodismo & - & M5 \\
\hline Mujer & 21 & Periodismo & - & M6 \\
\hline
\end{tabular}

Las personas moderadoras (C) iniciaban con una presentación pero trataban de no dirigir para evitar convertirse en voces autorizadas, voces expertas, asumían un rol de dinamización más que de dirección. Entendíamos que era fundamental para evitar las rutinas, las

propuestas prácticas para la Europa de los 27. Tolerancia Cero, Valencia, 19 y 20 abril 2007; Segura Cruz, M. del M. y Ramos Ruiz, A. (2007) Actitudes de la población malagueña ante la violencia de género. Málaga: Universidad de Málaga, D.L. 2007. 
opiniones comunes que buscan la aprobación de quien prescribe. Ante todo ponderamos la equivalencia entre todos los participantes y lo verificamos en sus intervenciones que denotaban confianza, complicidad:

“(...) pero ahora hay que tratarlo de una manera más natural porque nosotros mismos lo estamos tratando de una manera muy natural y lo hablamos porque el otro día hablaba de este tema con mis padres porque mi madre se cayó de unas escaleras, entonces fue al médico y lo primero que hicieron fue apartar a mi padre para preguntarle si el moratón que tenía en la cara había sido, que se lo había hecho... y lo hablamos con total naturalidad y nos parecía... Fue un momento cómico y positivo porque di tú que hubiera sido verdad que mi madre a lo mejor..." (H3)

"A mí me parece curioso lo que dicen de que a las mujeres les pagan menos. Yo eso aún no lo concibo, ni lo veo, ni lo he visto yo, no sé, me parece muy extraño. Sin contar ese detalle, que me sigue pareciendo súper curioso y que, según se dice, pasa, yo creo que tengo las mismas posibilidades. Bueno, yo por ejemplo, en el caso del periodismo, por ejemplo yo de corresponsal (...), tú vete de corresponsal a los Países Árabes, yo ahí creo que tienes menos oportunidades. Y que ahí te puede pasar cualquier cosa en comparación a los hombres porque, esto sigue siendo un mundo machista. Todas las leyes son, es decir, todo es machista si te fijas, pero, porque todo lo han creado los hombres, desde siempre. Entonces, sin contar eso, es decir, por ejemplo, yo me quedo aquí en España de periodista y tal, y yo creo que tengo las mismas que ellos. Ahora, también te digo otra cosa, veo que por ejemplo, yo ahora llego, me pongo así en plan tontita y tal para conseguir una información, y sé que me la van a dar a mí antes, me van a dar más facilidades por ejemplo las fuentes, que a un hombre, por ser mujer". (M6) 
Metodológicamente ${ }^{128}$, el grupo de discusión ha de tener en consideración las condiciones comunicativas o conversacionales que se establecen. Ciertamente, los/las participantes conocen que son entrevistados en cuanto estudiantes de materias de Comunicación y su rol profesional es tan importante como las variables de selección jóvenes universitarios de ambos sexos. Desde esa perspectiva se produce una "conversación para un agente exterior y bajo la ideología de la discusión como modo de producir la verdad"129 y se reconocen en tanto iguales:

"Pero, también digo una cosa. Yo estoy hablando de que yo soy universitaria, pero a lo mejor en las clases más (...), que no tienen estudios y tal, y que (...), ¿Sabes? No sé. En esa clase de social, yo creo que sí se sigue viendo como antes". (M6)

"Eso es un factor. El factor familiar es fundamental. Pero también el factor cultural. Seguro que hay una estadística. Personas con estudios superiores son menos propensos a ejercer el machismo que personas (...) Infinitamente menos. El nivel cultural supone progreso. En este caso, progreso supone menos sexismo". (H4)

Aunque desde 1996 la Organización Mundial de la Salud considera a la Violencia de Género como un problema de salud pública, el modo en que la mayoría de las personas tienen alguna información o conocimiento sobre la violencia machista es precisamente a través de los medios de comunicación y particularmente mediante los programas informativos. Esta circunstancia es fundamental para entender el orden social y la subjetividad de los participantes, pues se enfatiza ese sentido de ser, a la vez, parte y artífices de este

\footnotetext{
${ }^{128}$ CANALES CERÓN, Manuel \& BINIMELIS SÁEZ, Adriana (1994). El grupo de discusión. Revista de Sociología, O(9), pp. 107-117. doi:10.5354/0719529X.1994.27647

${ }^{129}$ Ibídem, p. 112
} 
conocimiento generalizado con sus logros y con sus déficits, sobre todo en el grupo de varones:

"pero yo creo que es la culpa de los medios. Por eso nos quedamos en lo que nos quedamos. Nosotros como futuros profesionales de la información, que profundizamos en el tema, nos damos cuenta de esas cosas, pero yo creo que los medios no ayudan en nada". (H5)

Que no es tan acusado en el caso del grupo de mujeres que se piensan más como sujetos de la investigación que como productoras de la información:

"En mi caso, porque yo los demás no lo sé, en mi caso la televisión, pero porque te están ofreciendo imágenes y tú ves la imagen del cadáver, tú ves las imágenes de las pruebas, ves (...) le ves la cara al asesino, al supuesto, ¿No? Como se dice en los medios de comunicación, del asesino. Lo puedes leer en un periódico, pero no te va a afectar tanto, o en la radio lo puedes escuchar pero no te afecta. Te afectan las imágenes que ves, entonces ya te creas un concepto". (M5)

Si bien encontramos un caso que transitaba desde lo general a lo personal en una suerte de confidencia:

"Pero eso lo sabemos nosotros que estamos estudiando esto, pero el problema es la población en general. Entonces, la televisión es el único medio de información que tiene. Entonces, si en el único medio de información que entra en una casa empiezas a tratar este tipo de conceptos sin cuidado, te puedes equivocar y puedes lanzar un mensaje equivocado, un mensaje equivocado, ya que en muchas familias, en muchas casas, la mujer es la que ejerce la violencia, pero otro tipo de violencia, viendo que está respaldada por la sociedad en un concepto que ella utiliza. Entonces, hay que tener mucho cuidado con esto. Hay que tener mucho cuidado con esto porque yo no sé aquí en esta mesa, pero yo sí he sufrido violencia de género...”. (H2) 
Como participantes en el grupo, los sujetos definen pues la realidad, son conscientes, y entendemos que también prescriben la manera de verlo:

"Es algo que muchas veces va incluido. Entonces, por eso los medios deberían trabajar un poco en buscar algo que no excluya porque también hay casos de hombres que son maltratados por la mujer. Son menos, pero no se pueden obviar. Cuando son hombres maltratados, también tienen la presión social de si denuncian la situación se van a ver como un poco más marginados dentro de la sociedad. Entonces, creo que deberíamos buscar desde la sociedad y a través de los medios una forma de hablar de la situación y que abarque a todas las posibles opciones cuando ocurra esta violencia y que se mejore en este aspecto". (H5).

"Básicamente, que los medios cumplan su función de información, más que de crear prejuicios. Telecinco aún suelta violencia machista. Yo cada vez digo: "Jolín, esta gente está ahí, son profesionales y sueltan esa burrada". No sé, me parece una burrada. Yo creo que es de una mala ética profesional. Es que se está dirigiendo a todo un país. Es una responsabilidad. Y que utilicen esos términos... No sé si es que sufren presión de algún tipo, pero... (H2).

CH: Hacéis mucha referencia a Telecinco...

"Espectacularidad, espectacularidad" (H3)

"Claro, el problema es que no somos conscientes de que todo se vende como un espectáculo, y la gente siempre le gusta más el espectáculo que (...), que pensamos" (M1)

"Si quieres estar informado, no veas la televisión. Si quieres ver un espectáculo, ve un partidito de fútbol. Si quieres ver una serie, ve la televisión. Es entretenimiento, por supuesto" (H5) 
El debate sobre la coalición violencia y televisión como ejes de la espectacularización está presente y permea todo el discurso. Es una constante en la que parece imponerse el pesado lastre de la costumbre. No podemos negarlo pero también parece necesario reavivar, instar a la reflexión y comprometerse en tanto ellos y ellas van a ser los creadores de estas narrativas. Resulta curioso cuando no alienante el alejamiento, el extrañamiento, de quien observa una realidad que se elabora día a día y que opta, al parecer, por la protección mas que por la acción. Este tipo de comentario avala nuestra propuesta: la implicación pasa, previamente, por el conocimiento, la crítica y la actitud propositiva de quienes van a construir estos mensajes.

"El telediario es violento. Yo me pongo delante de un telediario y es violencia pura. Buscan su espectáculo. Además, tiene su orden: presentación, internacional, todo, y luego tontería y deportes. Y la violencia machista, y además ellos dicen violencia machista con acento y con volumen, buscando la palabra que se escuche bien y capte la atención. Tú ves que están utilizando algo, que han generado una..., cómo decirlo, socialmente tienen mucho eco porque además está acompañado por una campaña del Estado, publicidad y demás. Entonces, utilizan todo eso para generar un circo y creo que con esto hay que tener algo más de responsabilidad. Es sufrimiento de mucha más gente lo que estamos tratando". (H2)

"La culpa la tienen los medios y esa influencia podía haberla mostrado en los canales de televisión, que es el medio que más alcance tiene, que llega a todos los hogares y que a partir de ahí podría cumplir esa función social que está implícita en los informativos. Los informativos lo que hacen es quedarse en la generalidad, en la sordidez y en la sangre y en el mismo hecho de las muertes y los asesinatos y en el espectáculo en sí, pero yo no veo en las piezas informativas cuando se informa de la muerte de mujeres que al final pongan el teléfono de ayuda o saquen a un psicólogo o hablando de que hay que 
denunciar (...) Pasamos muchas horas frente al televisor y el televisor tiene que cumplir también esa función social que tiene. Entonces, hay que incidir en cómo los medios tratan el tema porque los niños y los jóvenes están expuestos muchas horas a la televisión" (H6)

"Yo creo que habría que meter presión a los medios para que, por motivos de agenda, no seleccionaran sólo las imágenes que fueran sangrientas. Porque lo que no puede ser, es que yo tenga que levantarme (...), vamos a ver, encender el televisor a las tres de la tarde y ver una cosa que me resulte muy triste y, además, desagradable” (M2)

Indiscutiblemente, es preciso abandonar la idea de que compromiso supone intervención y, consecuentemente control. Dice M6: "Es que yo lo que creo que en periodismo a lo mejor sí, porque (...), como se ve se usa mucho eso (...) ese tema en la agenda mediática. Lo que pasa es que yo creo que eso es como la asignatura de la ciudadanía que hay ahora en la ESO. Creo que eso es ética de la propia persona y tú tienes que saber que eso está mal. Es decir, tú no puedes llevar (...), no sé, yo creo que en periodismo sí, pero en las carreras (...) en todas las carreras de la universidad no, porque ya estás imponiendo". Paradigmático es el diálogo que se produce entre M6 y M1: "Pues, yo sé que está el Instituto de la Mujer y, seguramente, evidentemente, van a ir a apoyar a la mujer y tal. Pero yo creo que hay cosas que las hacen mal. Son demasiado feministas, ¿Cómo se dice la exageración?".... "Hembrismo. (...) Que no es porque sea mujer tiene que tener, que tampoco tenemos que hacer eso. Se tiene que luchar por la igualdad de la mujer y el hombre, pero igualdad, no por la superioridad de la mujer ante el hombre, si no es que caemos en lo mismo" (M1). Ninguna de estas dos estudiantes tenía formación en materia de igualdad; otra le responde: "Que quería decir que luego llegas a un medio de comunicación a hacer prácticas y te tienen que corregir tus compañeros, diciendo estás usando lenguaje sexista, porque tú misma no te has dado cuenta, y a mí precisamente me ha pasado este verano. O sea que, qué menos que una formación en eso" (M3) 
Con todo y pese a que al menos tienen ciertas preocupaciones respecto al uso correcto e inclusivo del lenguaje, en relación al tratamiento de la violencia machista en los medios y su (in)adecuación, se manifiestan contundentes:

- "Como tú has comentado, la información es mercancía y las cadenas de televisión son empresas y van a intentar tratar este tema convirtiéndolo en un espectáculo y para así conseguir más audiencia, ¿no? No sé qué pensáis, pero el tratamiento de la violencia de género es siempre de manera sórdida. (H6)

- Pero yo creo que no estamos hablando de si está mal o está bien. Estamos hablando del tratamiento, ¿No? De la violencia de género, entonces yo creo que sí que debería existir una asignatura que no sólo abarque la violencia de género, sino todos los aspectos. (M5)

- Yo creo que para nada es adecuado porque además se limitan a contabilizar fallecidas en el caso, sin llegar nunca a saber qué castigo se le está haciendo o se (...) Se limitan a decir ha muerto una chica en tal sitio, pero nunca se hace un seguimiento de qué pasa a ese hombre, ¿Ese hombre entra en la cárcel?, ¿No entra? No, simplemente recuentan y ya está. Lo impactante y es lo que vende. (M2)

- Es una concesión del Estado y el Estado tiene una concesión absoluta de que lo que informe Telecinco o Antena 3 también depende de ellos. Estoy de acuerdo con él en que el Estado tiene que trabajar para que se abandone ya este sensacionalismo barato en cuanto a la violencia de género porque es vergonzoso. (H5)

- Un cambio en la imagen que dan los medios de comunicación, porque es que son el factor fundamental en la sociedad. Es que ya lo ves y dices, ay pobrecilla, otra se ha (...), pero te quitan hasta la sensibilidad hacia ese problema, que cuando tú lo vives en persona, dices: Esto es fuerte. Yo no sé qué hago viendo esto, y que, ¿Sabes? Y luego te lo muestran como: Un (...), como han dicho antes, un número más y (...). No sé. (M5) 
- CM: ¿Cómo pensáis que se podría comunicar ese tratamiento en los medios de comunicación?

- Actuar, ¿No? (M5)

- Así y como también ha dicho M2, que hubiese un seguimiento, que no sea una cosa cuantificada, que hubiese un seguimiento. O también buscar antecedentes de por qué se ha llegado a esa situación, ¿Cómo ha sido?, ¿Qué indicios ha habido?” (M3)

Como bien concluye M3, la contextualización del problema y su seguimiento más allá del suceso y del enfoque episódico constituyen la base de todas las recomendaciones institucionales y profesionales $^{130}$. La mera enumeración de casos contribuye primero a la adicción y luego a la distorsión; el enfoque integral del fenómeno exige el seguimiento y la resolución ${ }^{131}$.

\section{De la crítica a la acción, pasando por la formación}

La Ley orgánica 1/2004, de 28 de diciembre, de Medidas de Protección Integral contra la Violencia de Género insiste en la prevención y en la educación. Solo de esa manera se asegura el rechazo social, se trabaja en un horizonte que, junto a la intervención, certifica la repulsa de los comportamientos violentos. Y además, en la formación en Comunicación, la concienciación, la reflexión y el adecuado tratamiento informativo contribuye decididamente a modificar los parámetros de producción y de recepción. Este es el sentido del Observatorio de la Violencia (Ob-Vio) pero también lo es la formación trasversal que se ha implementado a lo largo de la última

\footnotetext{
${ }^{130}$ Recomendaciones Instituto Andaluz de la Mujer (1999); Manual de la redacción del Diario Público de 20/01/2008, actualizado a 03/11/2009; Recomendaciones del Consejo Audiovisual de Andalucía sobre la aparición de menores en emisiones de televisión y radio relativas a sucesos luctuosos, dramáticos o relacionados con conductas ilegales de marzo de 2009; Recomendaciones sobre el tratamiento de la violencia machista en los medios de comunicación del Consejo Audiovisual de Cataluña (2010), etc.

131 ALADRO VICO, Eva Violencia y medios: distorsiones y adicción. http:/ / eps-salud.com.ar/Pdfs/Violencia $\% 20 y \% 20$ Distorsion.pdf
} 
década así como el mainstreaming de género en algunas materias. Es un déficit que el alumnado percibe:

CM: “¿Cómo valoráis el tratamiento de la violencia de género en vuestra carrera?"

"Como en otras tantas, cero. Le doy un cero. Pero porque mi opinión ya, sé que me saldría un poco de lo de la violencia de género. Mi opinión en una facultad de Periodismo sería que, cada día, cuando se empezase una asignatura, primero se hablase de lo que ha ocurrido, la opinión de los demás, siempre referidos a esa asignatura, ya no te digo (...). Pero bueno, si ya dentro del periodismo, ya no se (...) o dentro de la facultad de periodismo no se habla de lo que sucede en la actualidad, ya entonces en violencia de género, ya te estoy respondiendo, no. No, fuera." (M5)

...aunque rechazando el enfoque de género

No, no, yo simplemente decir que ya no es sólo que se dé una asignatura o (...), bueno sí, una asignatura en este caso de violencia de género y se tenga que llamar así, simplemente que haya una asignatura en el que te indiquen cómo tratar diferentes temas, que nos sabes cómo tratarlos, que no sabes cómo abordarlos, que no (...). Porque sí, está la violencia de género, pero también hay otro tipo de temas, como estaba diciendo mi compañera Eva, que tú realmente te quieres enfrentar a ellos, y como no sea por decisión propia, por algún trabajo, por alguna optativa. Que son optativas las que realmente luego sacan tu (...), tu digamos tu ambición, o tu instinto periodístico, que es que no son ni troncales (...) que me enseñen a tratar, no sé, una guerra." (M1)

En el fondo no es más que la evidencia de ese sexismo sutil que oscila entre la corrección política, que conoce la importancia del asunto pero que evita el compromiso ideológico. 
Particularmente interesante es el intercambio de ideas que se produjo en el grupo de varones, especialmente reforzado porque fue un profesor en una asignatura optativa de carácter esencialmente práctico quien abordó el asunto.

"Pero yo creo que en lo que sí tiene responsabilidad la Universidad es en formarnos a la hora de tratar esa violencia y no lo hace. Es decir, yo en Comunicación Audiovisual hemos llegado a Cuarto y alguna referencia a eso hemos tenido hace un mes en una clase, con el profesor A.. Estábamos viendo cómo los informativos dan las noticias y entonces quiso tratar cómo los informativos dan la violencia de género, cómo tratan esa información. Hicimos un debate en clase parecido al que estamos teniendo aquí, pero... (H5)

CH: ¿Os puso vídeos y los comentabais? ¿Cómo era el proceso, la metodología?

Era una optativa. (H6)

Claro. (H4)

Era el interés particular de un profesor que sí le interesa ese tema y quiere tratarlo con sus alumnos, pero si no tiene ese interés ese profesor concreto, nos licenciamos y aquí no se trata nada de cómo tratar, no se forma para que nosotros tratemos la violencia de género. Luego, claro, llegamos a las empresas y eso, y hacemos..." (H5)

De esta manera se sorteó la sensación de agravio y adoctrinamiento que algunos acusan:

-Sobre las ayudas a la producción audiovisual- "Lo que sí hay un tema que me da mucho coraje y lo voy a decir antes de que terminemos el debate porque afecta a los de Comunicación Audiovisual, pero también a los de Periodismo. Esta terapia de choque también tiene su efecto negativo y nosotros lo estamos conociendo ahora. (...)Pero hay un punto que me da mucho coraje, que es que tienes 
cinco puntos de 60 o no sé cuántos son, los tienes ya directamente por ser mujer" (H3)

De 2007 a 2011 en colaboración con el Instituto Andaluz de la Mujer se ha impartido el curso de libre configuración La Mirada de la Mujeres en la Sociedad de la Información, cuyo objetivo principal fue promover el conocimiento del alumnado de la facultad de Ciencias de la Comunicación sobre las dimensiones del género y su problemática científica y social como formación complementaria del alumnado de Comunicación en las Facultades de Sevilla y Málaga. En 2011 se incorporó a la experiencia la Asociación de la Prensa de Málaga. Paralelamente, se desarrolló como titulación propia el Curso de Especialización en Comunicación para la Igualdad en colaboración con el Ayuntamiento de Málaga (2010-2013)

Desde 2011, como resultado del Primer Plan de Igualdad de la Universidad de Málaga ${ }^{132}$ se forma al personal Docente e investigador en Igualdad para que implementen en sus respectivas materias indicadores, lecturas, referencias y experiencias igualitarias; ya que se detectaba la necesidad de incidir en la formación en valores intrínsecos a la cultura universitaria, especialmente la igualdad. Previamente, los diferentes Libros Blancos de las titulaciones de Periodismo, Comunicación Audiovisual y Publicidad y Relaciones Públicas precisaban como competencia trasversal la generalización de una conciencia igualitaria sobre las personas y los pueblos, y el respeto por los derechos humanos internacionales, así como conocimiento de las grandes corrientes culturales o civilizadoras en relación con los valores fundamentales individuales y colectivos. De esta forma, se pretendía incentivar la implementación de la perspectiva de género en la enseñanza-aprendizaje de las diferentes materias, especialmente en el área de las Ciencias Sociales pero en general para vincular la docencia con los valores intrínsecos de la cultura universitaria: la autonomía del pensamiento y la ética del

\footnotetext{
${ }^{132}$ Primer Plan de Igualdad de Género en la Universidad de Málaga (2010) http://www.uma.es/media/files/264.pdf
} 
conocimiento, y la conexión de la formación en igualdad con la responsabilidad social, la empatía y la tolerancia.

Luego, tras su implementación, el vigente II Plan de Igualdad de la Universidad de Málaga ${ }^{133}$ (2014-2018) establece el desarrollo de acciones insertas en los respectivos ejes temáticos, especialmente en el EJE 2. DOCENCIA mediante las siguientes medidas:

MEDIDA 2.1. Aumentar y consolidar la temática de género en los planes de estudio de grado

MEDIDA 2.2. Visibilizar la aportación de las mujeres en todas las ramas del conocimiento

MEDIDA 2.3. Promover la docencia y la investigación en género en los másteres y programas de doctorado.

MEDIDA 2.4. Incluir la perspectiva de género en la oferta de títulos propios, cursos de verano y seminarios de la Universidad de Málaga.

MEDIDA 2.5. Incentivar que los centros adopten estrategias de captación, sobre todo en las enseñanzas muy masculinizadas $\mathrm{O}$ feminizadas y analizar su impacto

MEDIDA 2.6. Realizar acciones específicas de sensibilización dirigidas al alumnado de la UMA, con el objetivo de combatir los estereotipos de género en las carreras profesionales.

Desde que adaptamos nuestros planes de estudio al marco europeo de Educación superior, se explicita como competencia trasversal los principios generales recogidos en el artículo 3.5. del RD 1393/2007, según los cuales las enseñanzas serán impartidas "desde el respeto a los derechos fundamentales y de igualdad entre hombres y mujeres", "desde el respeto y promoción de los Derechos Humanos y los principios de accesibilidad universal" y "de acuerdo con los valores

${ }^{133}$ II Plan de Igualdad de Género en la Universidad de Málaga (2014-2018) http://www.uma.es/media/files/IIPIGULDAD.pdf 
propios de una cultura de paz y de valores democráticos". De la enunciación a la concreción hay un largo camino y los obstáculos se van haciendo cada vez más sutiles, pero las reticencias permanecen. Tan solo la formación y el conocimiento es garante de una apreciación más plural, más equitativa y justa de la sociedad. La vinculación de los conocimientos con la práctica profesional y la labor de mentorización de profesionales. Ese es el sentido de Ob-Vio: mostrar para conocer, conocer para proponer, proponer para crear alternativas. En aras de la equidad, pero también de la calidad del Periodismo:

"Yo creo que, como en todas las profesiones, hay que renovarse. Yo acabo este año Periodismo, lo que no quiere decir es que, cuando yo salga al mundo laboral, yo me limpio las manos y yo no tengo que seguir (...), renovarme, renovándome. Entonces yo creo que el problema es que los que están trabajando ahora en los medios de comunicación, deberían de impartirles unas clases, una formación, para saber cómo. Porque la violencia de género, queramos o no, es algo que acaba de salir. Es muy novedoso, aunque siempre ha existido, pero ahora es muy novedoso. Pues vamos a enseñarles, yo no por supuesto, pero, tienen que aprender ahora cómo vamos a tratar ese tipo de información”. (M5)

Como afirma M5 tienen que aprender, tenemos que aprender. Tres años después los grupos de discusión realizados con espectadores y espectadoras sobre estas informaciones emitidas en Canal Sur revelan un nivel de concienciación y de reflexión ciertamente implementado ${ }^{134}$. Reconocen rutinas y enfoques estereotipados; demandan tratamientos más equitativos y proactivos; pretenden una formación adecuada para los informadores e informadoras; nos avala la razón y la necesidad, y en eso estamos.

\footnotetext{
${ }^{134}$ Véase el capítulo 3 de este volumen, titulado Después de las noticias: experiencias con los grupos de discusión en el observatorio andaluz de violencia machista en los medios audiovisuales, escrito por Concha Barquero Artés.
} 


\section{Referencias bibliográficas}

Canales Cerón, M. y Binimelis Sáez, A. (1994). El grupo de discusión. Revista de Sociología, O(9), pp. 107-117. doi:10.5354/0719529X.1994.27647

Díaz-Aguado, M.J., Martínez, R., Martín,J., Carvajal,I., Peyro,M.J., Abril,V. (2010). Igualdad y prevención de la violencia de género en la adolescencia. Madrid: Ministerio de Sanidad, Asuntos Sociales e Igualdad.

Ministerio de Sanidad, Servicios Sociales e Igualdad (2011). La juventud universitaria ante la igualdad y la violencia de género http://www.msssi.gob.es/ssi/violenciaGenero/publicaciones/estudi osinvestigaciones/PDFS/Juventud Universitaria.pdf

Ministerio de Sanidad, Servicios Sociales e Igualdad (2015). Percepción de la violencia de género por la adolescencia y la juventud

https://www.msssi.gob.es/ssi/violenciaGenero/publicaciones/estudi osinvestigaciones/PDFS/Percepcion Social VG Adolesc Juv.p $\underline{\mathrm{df}}$

Universidad de Málaga (2010). Primer Plan de Igualdad de Género en la Universidad de Málaga (2010)

http://www.uma.es/media/files/264.pdf

Universidad de Málaga (2014) II Plan de Igualdad de Género en la Universidad de Málaga (2014-2018) http://www.uma.es/media/files/IIPIGULDAD.pdf

Vera Balanza, M. T. (2005). Medios de comunicación y violencia de género: un idilio pérfido, en Documentos de trabajo social: Revista de trabajo y acción social, n. 35, pp.35-48. 



\title{
El cuerpo, esa insoportable lengua comunal
}

\author{
Margarita Ledo Andión \\ Universidad de Santiago de Compostela
}

\begin{abstract}
TAL VEZ porque este texto lleva consigo la ausencia de marcas 1 en el cuerpo, a penas se reconocería como pequeño tratado sobre algunas condiciones que crean y reproducen mecanismo violentos sobre, en este caso, las mujeres migrantes. Empiezo este relato, casi íntimo, como creadora y como ensayista, como alguien que escribe y hace cine porque también es docente e investigadora; alguien que desde el feminismo incorporó la necesidad de armonizar actitud y opinión, el modo de actuar desde un modo de pensar, y las políticas del cuerpo - de la experiencia, de la materialidad de la existencia- como escenario en el que se representan y expresan, por entre la psicopatología de la vida cotididana, todas las variaciones del encuentro.
\end{abstract}

"Your body is a battleground" (tu cuerpo es un campo de batalla), desde aquella consigna expandida de la artista conceptual feminista norteamericana Bárbara Kruger, cada vez que escuchamos la palabra cuerpo, otrora tan oculta, sabemos que en ella se entrelazan género y política de representación, sexismo y violencia, precariedad y 
dependencia; sabemos que en ella se reactualiza, tal una maldición bíblica, una de las formas más degradas de relación humana: la trata.

Y como materia de trata, mujeres sin derechos en el puerto de origen y en el de llegada; mujeres sin papeles, en tránsito continuo, reencarnadas en los márgenes de las vías públicas, de las fronteras, de los empleos clandestinos, del trabajo puertas adentro, de las domésticas. Mujeres sin derechos y sin tiempo ni lugar para saberse con derecho a tener derechos. Mujeres lejos de aquellas otras mujeres, de las costureras que, en el medio y medio del siglo diecinueve, se unían a la desobediencia de curtidores, impresores, sastres... para ser protagonistas de la conquista de la noche para ellas. Lo recogió para nosotras Jacques Rancière en La nuit des prolétaires (La noche de los proletarios) a través de vestigios diversos, a través de sus periódicos, de sus hojas volanderas, de sus poemas, de su actitud emancipada. No, no se trataba de rebelarse contra los salarios de hambre, contra la explotación sin par. Se rebelaban, como nos explica el filósofo comunista, contra el dolor del tiempo robado, contra la pérdida literal de la vida, contra el trabajo a destajo y el sueño que sólo les sirve para recuperar fuerzas. Por eso deciden darle la vuelta a las palabras sueño y soñar, adentrarse en la noche, agruparse, gozar.

Pero si el ronsel luminoso de las goguette, de esos espacios colectivos en los que reunirse para beber y para cantar las letras que las y los trabajadores inventaban y adaptaban a melodías conocidas, se extinguió bajo prohibición napoleónica en 1851, la plaza pública siguió animándose con estrellas fugaces y con acciones que dejaron su huella en espiral para que la historia pudiese avanzar. Por eso, a pesar de retrocesos a base de látigo, de complicidad sin consentimiento con el poder patriarcal, de la sumisión de nuevo a las tareas del hogar, a la reproducción no planeada, no consentida, no querida, a pesar de (auto) condenarnos a transmitir su jerarquía, sus valores, la división de roles como natural, las mujeres saben que su cuerpo es, quizás, su única y vulnerable posesión. Y sobre el sentido de esta posesión hice una película.

Como pieza de aprendizaje, como ejercicio compartido, me decidí a de-construir no tanto un resultado, una obra de nombre $A$ cicatriz 
branca, como las pistas, las señales, los desasosiegos, los indicios que me hicieron escoger una u otra salida y volver la vista hacia la continuidad, a lo largo del todo el siglo veinte, de un fenómeno que se extrema -si es que esta palabra tiene ya sentido- en tiempo presente: los movimientos de masas humanas y las mujeres traficadas.

Hago un paréntesis imaginario para recordaros, desde los sesenta y hasta la actualidad, los fotomontajes sobre el cuerpo de otra artista sino reconciliada con el sistema, Martha Rosler, que con su serie Body Beautiful realizó auténticas proclamas que puntuaron las mil expresiones de la dependencia. Títulos como "Culto al cuerpo", "Fantasía de maternidad", "Limpiando las cortinas"... se alargaron hasta tocar lo sagrado, el hogar, el culto a la casa y la guerra en casa: Vietnam, Iraq, y lo acompasaron con un giro lingüístico que se nos presenta como Bringing the War Home: House Beautiful: First Lady en la que la agitadora Rosler sitúa a la señora Nixon sobre un fotograma de la Fane Danaway de Bonnie \& Clyde, una película- comenta- que en Estados Unidos se convirtió en un manifiesto de rebelión para mi generación.

Antes de reflexionar sobre mi propio trabajo, sobre aquel más autoral, es decir, sobre el que asumo la responsabilidad total -del guión a la dirección y, a partir de la primera película, en 2004, de Santa Liberdade, la producción- quiero remarcar este sentido de pasaje: tú haces una obra para otra en la que te incluyes; tú vas haciendo un filme que te va haciendo, que te va explicando, hasta el punto de que en ocasiones no llegué a ver la razón primordial de cómo usé el dispositivo, de por qué aparecen ciertas figuras expresivas hasta pasado cierto tiempo y hasta que para una mesa redonda organizada por la "Asociación de escritoras y escritores en lingua galega" (AELG) tuve necesidad de preparar un trabajo sobre la adaptación, sobre el paso de la literatura al cine. En ese instante, al analizar la metamorfosis de un poema ${ }^{135}$ en una secuencia para el corto Cienfuegos, 1913, supe que todo entró en conexión en función

\footnotetext{
${ }^{135}$ Margarita Ledo Andión (1989) Linguas mortas, serial radiofónico, Santiago de Compostela, Sotelo Blanco. Fotos: Anna Turbau
} 
de filmar un abrazo. Mi voz, mientras la cámara/espectadora va rodeando esta imagen, decía el siguiente texto: “... cando voltei do exilio, cando me amnistiaron, miña nai mentres prancha unha saba comentame moi seria: sabes, preguei para que che nacesen ás."

“... cuando volví del exilio, cuando me amnistiaron, mi madre me comenta muy seria mientras plancha una sábana: sabes, recé para que te nacieran alas."

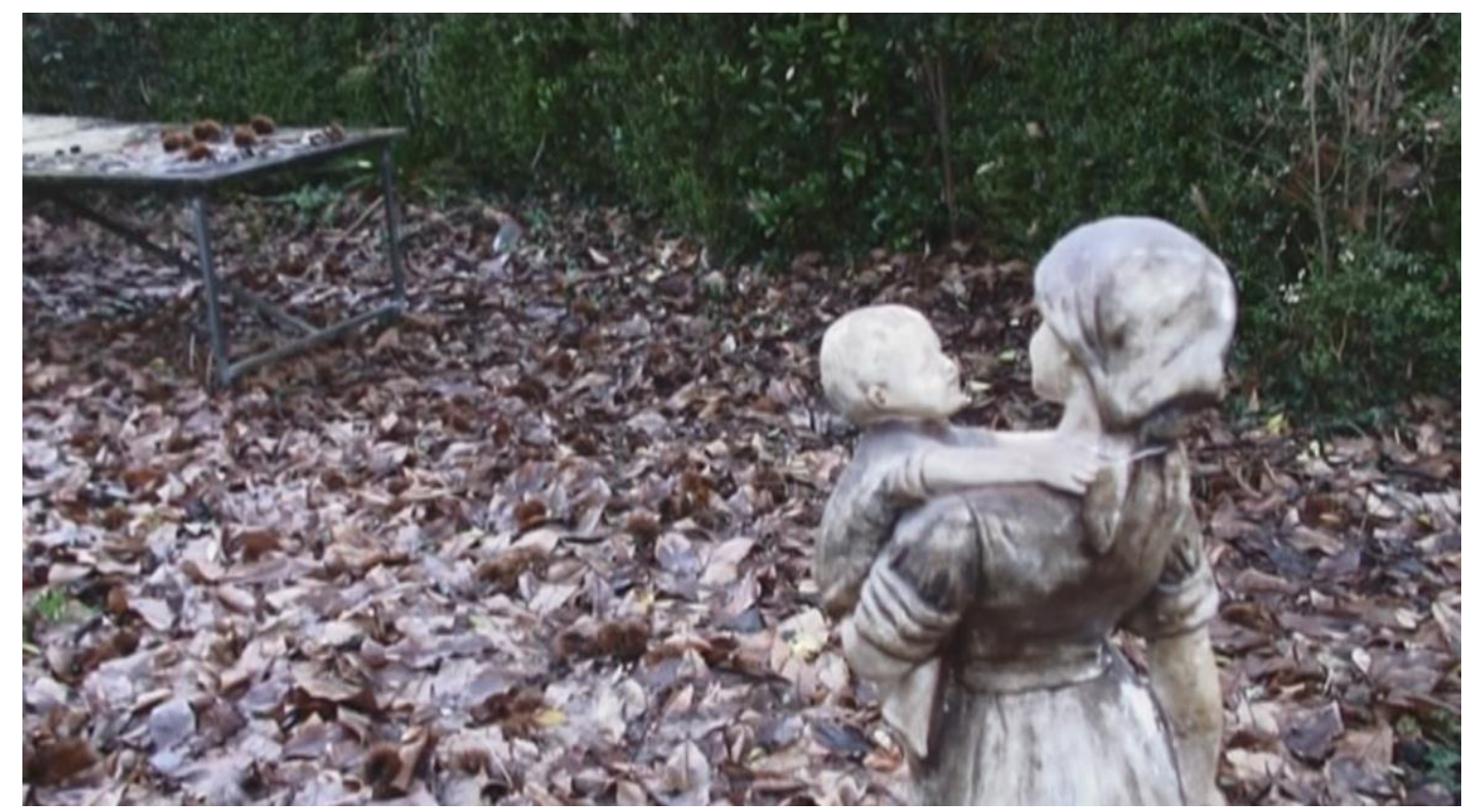

"Un image ne se prend pas, elle est produit (...) elle attend de ceux qui la produisent et de ceux qui la regardent, la constrution du regard qui lui donnera du sens " (Marie -José Mondzain)

Me interesaba comenzar este recorrido por un ejemplo de imagen y escritura con mi propia experiencia como referencia, con ese "je filme" que deviene un acto tal vez fundacional, y que me une con una de las prácticas más reconocibles del cine de mujeres al escoger aspectos biográficos y espacios reglados para entrar en su deconstrucción: de los roles, de los valores, de la incapacidad para decidir, de la instrumentalidad del cuerpo, del discurso amoroso como fragmento sin zurcir, y hasta atrevernos a levantar la mirada sobre nosotras mismas como materia primigenia, sobre nosotras en ese estado que aún no es, en ese -si nos acogiésemos al vocabulario del psicoanálisis- ámbito matrixial. Y me interesaba comenzar por la 
voz del yo, en este caso por mi propia voz, por la voz como figura fílmica y como exploración, como voz que al crear formas de pensamiento, produce una, dos tres, infinitas acciones en potencia.

Como cuando me reconozco en una intervención sobre la ausencia de la voz femenina, Ruta Remake, en un proyecto de las artistas lituanas Nomenda \& Gediminas Urbonas ${ }^{136}$ con la voz como corpus tono, timbre, entonación, ritmo...- precisamente en su relación con el cuerpo. La explicación que acompaña esta propuesta intelectual y socio-artística nos dice que el trabajo se compone, además de piezas de archivo, de entrevistas a mujeres lituanas que trabajan con la voz en territorios diferentes: escritoras, lingüistas, musicólogas, cantantes, activistas... para investigar la voz de la mujer y el papel que desempeña en la "construcción de un escenario de víctimas".

Atrás, y como paisaje que nos engulle, el mito de Narciso y la ninfa Eco. Narciso se mira en las aguas y se prenda de si mismo, del canon de belleza que él mismo define, y la ninfa, dentro de las aguas, se prenda de la voz masculina. A partir de ese momento ya no es capaz ni de desenvolver ni, por lo tanto, de reconocer su propia voz. Por eso el eco solamente repite. Por eso las mujeres estamos condenadas a repetir -y no podemos nunca contradecir- lo que dice el varón. $\mathrm{Y}$ así, de esta manera tan melancólica Eco, la ninfa, no puede decir nada sobre sí misma.

Pero, de manera enigmática, eso que se llama resistencia se labró con determinadas prácticas en torno y desde lo femenino, como lo es el placer de escuchar $o$, mientras citan a Hélène Cixous, entre la proximidad de lo escrito y lo hablado en la obra de las mujeres, gesto que localizo de manera insistente en mi misma y en esa cierta obsesión por filmar la palabra, este otro modo de pasaje de lo oral a lo visual, desde su misma interioridad, desde el silencio y hasta la manera de connotar la pérdida que me trasladó cada inflexión en la voz de María Casares en Gernika, (Alain Resnais, 1945): olvidarte de quien eres para poder ser tu misma-otra, dice la exilada para cubrir la

${ }^{136}$ Puede consultarse en los fondos del Macba. Véase www.macba.cat 
quiebra; o la narradora de Aurélia Steiner, de Marguerite Duras, que es la voz de todas las mujeres que pasaron por los campos de concentración y que están en la desesperación abismal de esta vOz de María Teresa Albajar ${ }^{137}$ en el transcurso de un homenaje en Galicia a las mujeres republicanas exiliadas, agosto de 2009 , en la que desde 1936 se convierte en prisión, en lugar de exterminio, la Isla de San Simón, donde en la Edad Media emergiera una de las más enigmáticas canciones de amigo del/de la poeta Mendiño:

E cercáronmi as ondas do alto mar;

Non ei i barqueiro nen sei remar

Eu atendendo meu amig'! E verrá?

Nen ei i barqueiro nen remador;

Morrerei eu fremosa no mar maior.

... Moriré hermosa en el mar mayor. La memoria de esa quiebra imposible de suturar se materializaba en las frases sin final de la hija de César Albajar: ... e a miña nai tivo que morrer coa morriña de Galicia, coa morriña do seu fillo..."

Y la notación de palimpsesto, de los diferentes niveles que nos constituyen, de lo íntimo expuesto, del pasaje de la ausencia del deseo al deseo, de la no vida a la vida en lo que Bracha Ettinger, en términos psicoanalíticos, llama la subjetividad maternal/del espacio matrixial, diferenciando la no vida del deseo de muerte que retorna a

${ }^{137}$ Illa, Margarita Ledo Andión (Galiza, 2009). 
lo largo de la vida, y aplicándolo a la lectura de poetas suicidas como Silvia Plath ${ }^{138}$.

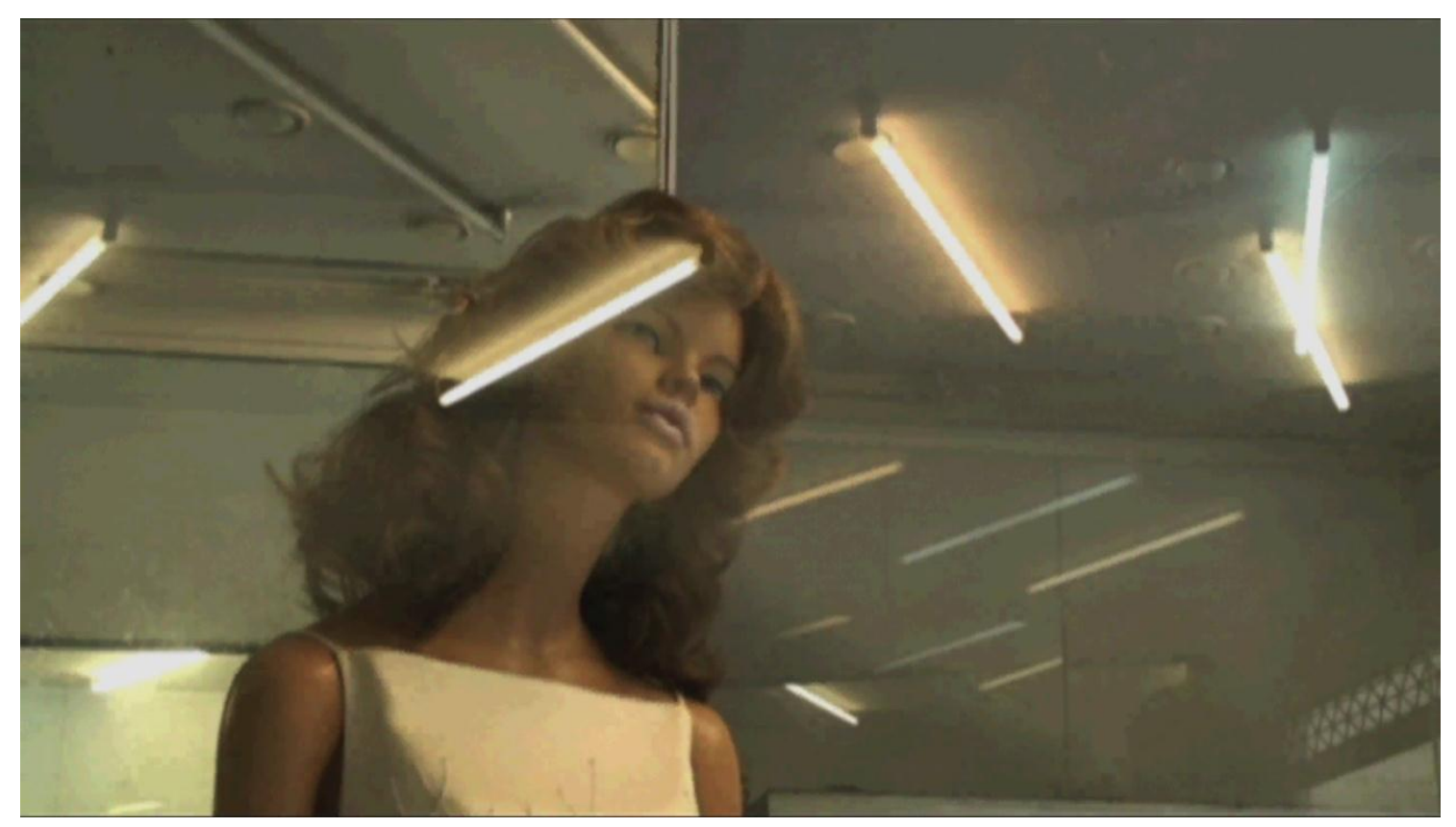

Hace algunos años Paloma Navares me pidió un texto para una exposición, frágil e inmensa, Del alma herida ${ }^{139}$, en la que le daba forma a poetas y escritores atravesados por el deseo de muerte, como Cesare Pavese, como Alfonsina Storni, como, de nuevo, Sylvia Plath. La atmosfera como figura artística fue el motivo que desenvolví y desde entonces le doy vueltas a esta construcción invisible, que se da entre la obra y quien la mira, a esa empatía sin compasión -términos de Bracha- como prueba de que es la obra la que te hace a ti, también cuando eres espectadora, es ese particular "ver/leer juntas" que en cada momento convertimos en un realizativo. Deseo de no vida que atraviesa la obra de una de nuestras referencias, Rosalía de Castro: ...porque aún no les está permitido a las mujeres expresar lo que sienten y lo que saben, una autora singular y comunal que, en el medio y medio de la plaza, expresó todas las diferencias: de

\footnotetext{
${ }^{138}$ Ettinger, Bracha Lichtenberg, 1999, Regard et espace-de-bord matrixiels, Bruxelles, La Lettre Volée

${ }^{139}$ Paloma Navares, 2006, Del Alma Herida, Madrid, Instituto Cervantes. www.navares.com/delalmaherida.pdf
} 
pensamiento, de nación, de género, de clase, de lengua. Fue fourierista como las costureras utópicas y en su literatura las mujeres se atreven a mirar para, sin pedir permiso, pasar - de manera radical- a actuar.

Un pasaje más hacia lo que me propongo destejer y que densifico en el deseo de no vida que atraviesa el cuerpo de las mujeres migrantes, y que tarda en llegar tal vez porque me encuentro bien en el estado anterior, el que aún no es, en la fase del idilio, del eros matrixial, antes de dar el paso incierto hacia lo real y hacer de ese real que duele, ficción. Quizás de esta manera - de nuevo Rancière- podamos pensar el dolor.

¿Y si en el bosque no existiesen árboles? Este interrogante está entre los motivos que me llevaron a emprender un viaje interior hacia lo no expresado, hacia la duplicidad submersa de la angustia de la mujermigranta, una persona que pasa a existir entre la representación de lo que quiere llegar a ser y lo que sabe que, por su misma condición, jamás será. Viaje hacia un proceso largo y repleto de huidas que en ocasiones permite acceder al propio reconocimiento y que se me reveló a través de algunos contactos esporádicos con ellas, con estas "extranjeras de sí mismas", con las mujeres que emigraron solas sin otro equipaje que una máquina de coser en la cabeza. Un proyecto que se extiende hasta rozar lo que apenas intuimos excepto si lo identificamos en algunos rastros porque nos agarramos a la consigna de François Truffaut para parecernos al cine que hacemos desde el realismo como pálpito inexperto, como tránsito de lo real a la ficción y como un resultado trabajado.

De lo más íntimo a la alteridad, ya no evitamos relatarnos en el mismo acto de relatar, transformarnos en mironas de las otras mujeres desde el interior de nuestro, tal vez, desasosiego original y echamos mano de la no ficción como lo próximo-lejano que sólo la persona que mira puede re-significar. Las otras, las mujeres que emigraron solas con destino a servir; ellas, las criadas, fueron mi material. 


\section{La historia y su backstage}

En la primera mitad del siglo veinte, miles de mujeres salieron solas de Galicia hacia América. Muchas de ellas eran ilegales, con papeles que falsificaban su edad e incluso su identidad. Iban, como dijimos, destinadas a servir.

En diferentes momentos y a lo largo de tres años recolectamos el testimonio de mujeres de tres generaciones unidas por el hecho migratorio desde un país, Galicia, que por Real Decreto de 1773 va a tener como misión poblar el Río de La Plata. Como suele acontecer, el propio proceso de procura de materiales para el filme $A$ cicatriz branca devino una obra en si misma, una pieza de aprendizaje de la autoestima a través de filmar la palabra.

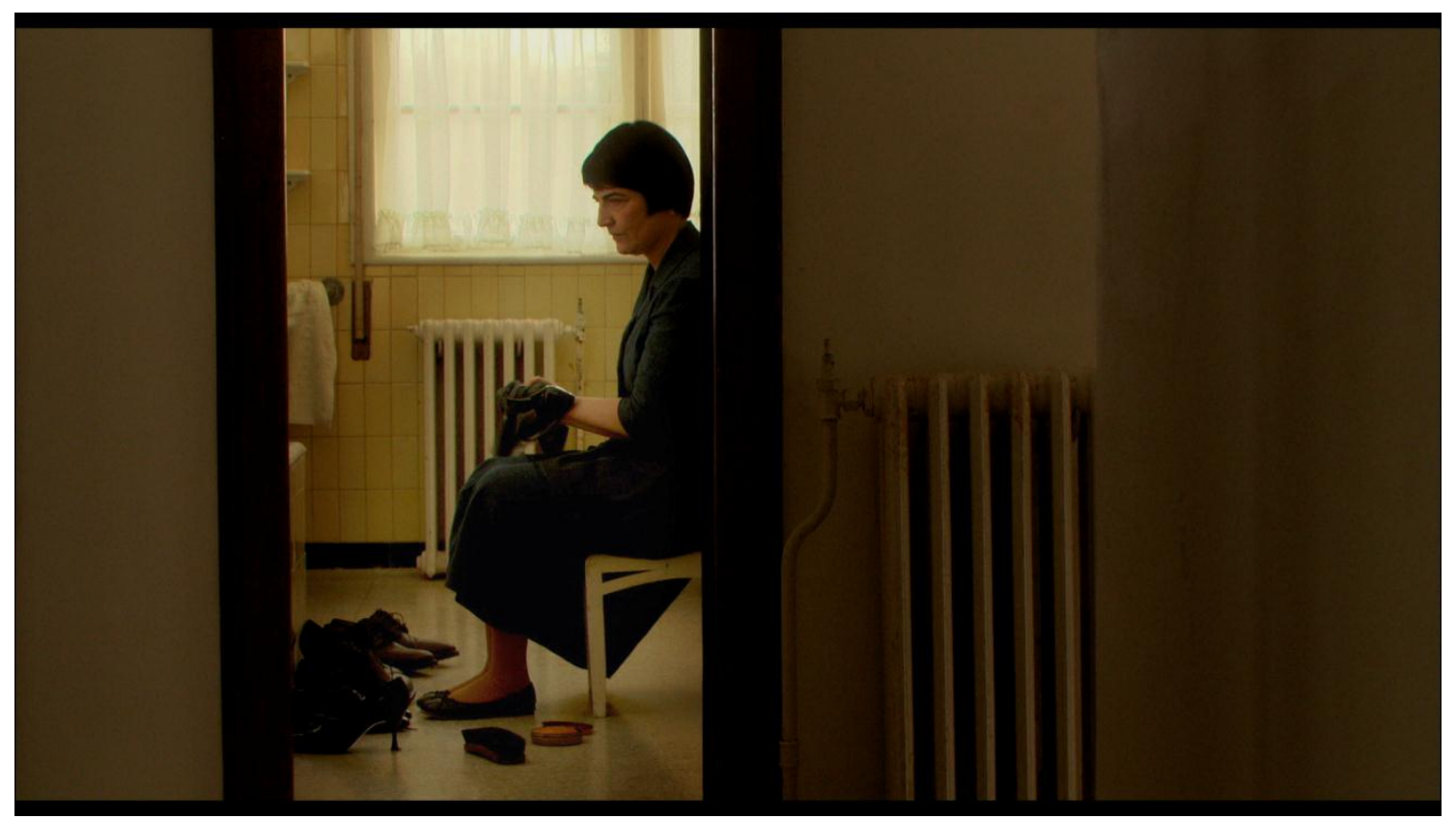

De lo más intuitivo a lo más reflexivo, las mujeres acceden a ser protagonistas de una narración colectiva que atraviesa diferentes épocas, desde la década de la "gran migración" (1920-1929) y hasta las que arriban en los años cincuenta o aquellas que ya nacen allá, en Buenos Aires. Ellas son las mujeres que desvelaron para mi la búsqueda de su identidad, su experiencia. Con ellas, a la par de dar a ver los materiales con los que se construyó $A$ cicatriz branca, hizo su 
aparición un mediometraje documental, Apuntamentos para un filme, que presentábamos de esta manera:

“¿Cómo te ves? Cómo te ven? ¿Qué conflictos salen hacia fuera? ¿Qué nos dicen, a día de hoy, ciertos momentos de existencia, los archivos, los lugares personales de memoria, el relato de mujeres que pasaron la experiencia interminable de aquella emigración? Estos interrogantes fueron el paisaje de fondo de un documental en el que cada fragmento, cada pequeña emoción, la expresión calma o la emergencia del dolor latente construyen una atmosfera de "eterno presente"."

Son gallegas de tercera generación como Micaela, que desde una perspectiva de género trabaja con mujeres migrantes que en este momento preciso llegan a Argentina desde Paraguay, Bolivia, Perú... o como María Rosa, que a los 4 años, en los cincuenta, llega con su madre para reunirse con el padre y que tendrá que desafiar, una tras otra, la prohibición familiar de "ser moderna" o, para no ser motivo de burla, de expresarse en lengua gallega. Como Isabel, que al casar deja la fábrica de medias y se hace ama de casa para, pasados los sesenta, ser abandonada y conseguir no sólo estudiar sino recuperar su identidad o como Débora, nacida ya argentina, gallega por opción, que discute cómo darle la vuelta a los estereotipos, además de las que son hijas del ambiente galleguista republicano y exiliado, Cloti Tacholas, o de Rosa Buján, que también vivió los años de movilización pro-Republica, que se emociona al intentar leerme un párrafo de Memorias dun neno labrego, de Xosé Neira Vilas, y que trabajo en una casa "en la que éramos once de servicio". De Amparo, de Ramona, de Segunda, de Carmen, de María Visita ...

"Ao chegarmos a porto, dúas señoras da igrexa católica fixéronse responsábeis de nós, das rapazas que viñamos soas. E dos nosos papeis. Para non ter que pasar o control de emigrantes, dixeron. A casa onde sirvo é boa. Hai dous rapaces. Agardo estea ben, aboa. Non deixe de comer..." 
"Cuando llegamos a puerto, dos señoras de la iglesia católica se hicieron responsables de nosotras, de las chicas que viajábamos solas. $\mathrm{Y}$ de nuestros papeles. Para no tener que pasar el control de emigración, dijeron. La casa en la que sirvo es buena. Hay dos niños, Espero que esté bien, abuela. No deje de comer..."

Así da comienzo la sinopsis de la ficción. Pero por detrás está esa niña de 8 años a la que le tocó venir por una fotografía; están las que salieron con una pieza de pan, un cobertor, una máquina de coser en la cabeza, seis camisas de lienzo para ofrecer a quien las venga a recoger y un quilo de azafrán en rama para costear el pasaje. Por detrás está la historia de Mercedes Méndez Fouz que, sin saber donde ir o donde acudir, pasó tres días y tres noches en la estación Constitución.

Ninguna está hecha con la materia de los sueños. Y quizás por eso en estos Apuntamentos cada experiencia es la experiencia en la que nos reconocemos mujeres diversas.

Las mujeres gallegas que emigraban solas eran acogidas en Buenos Aires por las Carmelitas Terciarias, las "Hijas de María" o por la "Sociedad Protectora de la Joven Sirvienta". Necesidad, abandono, agresiones sexuales, madres solteras... como causa, y una ciudad distante y burlona, en la que la mayor parte de ellas pasaron a tener la condición de "mucamas", de "criadas de camadentro", fue el paisaje de fondo para la ficción A cicatriz branca.

Representadas en el imaginario argentino como perritas fieles, trabajadoras y analfabetas; casi siempre como tercas, atravesadas y agarradas; como ocurrentes y chocantes en la serie radiofónica y cinematográfica Cándida; por veces como objeto de deseo, el "síndrome da galega" se identifican por ciertas fobias, una culpabilidad marcada, el miedo al ridículo y el pánico a estar en la boca de los otros, el temor a ser juzgada.

Tal vez los momentos más significativos para las migraciones femeninas sean los años veinte/treinta, con la guerra civil y el exilio 
como inflexión, y los años del peronismo, cuando la emigrante accede a la categoría de obrera industrial y se mira en el espejo de Evita.

Para la historia de A cicatriz, branca, la sospecha llega desde La Habana con una pequeña noticia sobre la proyección del filme Cándida, en el Cine-Teatro Payret. A partir de este evento cotidiano Fuco Gómez, director de la publicación Patria Gallega difunde una hoja volandera en la que, literalmente, se refiere a una Galicia calumniada, habla del desprecio al campesinado en la figura de la protagonista y de que, en 1940 y en Buenos Aires, los jóvenes de la sociedade "Mocedades Galegas" protestaran contra un sainete en el que "a muller galega fai un papel baixo, deshonesto e torpe" remitiéndonos, de nuevo, al filme Cándida.

"Una gallega baila mambo, Una gallega en México, Una gallega en La Habana, Cándida Millonaria...” el personaje de la gallega sentimentral, retranqueira y honrada dio de si hasta diez filmes que, con gran éxito, circularon de un país a otro en la procura de ese mismo público potencial que era su materia carnal.

Detrás están la(s) historia(s) ordinarias que lindan con episodios de abusos, prostitución, encubierta o manifesta, a través de redes que incluyen a familiares y a paisanos, o el acatamiento a los patrones que las usaban para la iniciación y adiestramento sexual -sin peligro de contagio- de los señoritos de la casa. La imagen de la gallega emigrante representada por el personaje de Cándida, que desde Argentina recorre Cuba, México o Venezuela, es el estereotipo de esta submisión.

El aislamiento en el espacio doméstico bajo control de la patrona, del patrón, la obediencia total -sin posibilidad de réplica ni de pensar siquiera en esa posibilidad-, y la disponibilidad para todo tipo de prestaciones, configuran a un ser borroso, la criada pobre y, si puede, revirada que quiere casar o, si se tercia, cazar al señorito, imitar ese otro mundo donde ella es una extraña. Porque, si en realidad ser criada no quiere decir ser prostituta, si entramos en la verdad de ese real, ser criada implica tener que hacer todo lo que te mandan. 
Cándida, ese producto popular de éxito, es uno de los síntomas que organiza as notas del viaje hacia la duplicidad de la mujer-emigrante, una persona -no nos cansaremos de repetirlo- que pasa a existir entre la representación de lo que quiere llegar a ser y de lo que, por su misma condición, sabe que jamás será.

Viaje lleno de obstáculos y de desvíos hasta que, tal vez hacia el final, se reconoce sin cuerpo ni capacidad de deseo. Pero más allá de la máscara, de la caricaturización, cuando esta condición toca lo más íntimo y familiar, cuando se manifesta, se convierte en aquella "inquietante extrañeza" freudiana que nos acompaña y que esculpe en vivo la zona donde todo se guarda. Por eso en medio de esta atmósfera de mujeres sobre las que otros "tratan", los hilos, en ocasión, tensan. Y somos con ellas, esa perdida total de la querencia. De la belleza. De la disponibilidad amatoria. Más que criadas, más que mucamas, mujeres que sobreviven en la representación de otra distinta que ni son ni tuvieron posibilidad de ser. Herida difícil, muy difícil de suturar y de representar.

"Soamente recordo que vostede dixo que cando eu saíse da casa, vostede, avoa, deixaba de enviar. Que pola súa gorxa non baixaría outro anaco de broa. Foron palabras que aínda non comprendo hoxe, hoxe cando eu propia deixei de enviar. Pro non recordo máis nada, nin sequera as liscas de luz branca con que o trebón ía sinalando aquela partida. Era coma se na miña cabeza ficara só a luz branca e a súa voz, avoa. O meu pescozo termou todo o tempo da mala sen a penas magoarme na espiña como facían as sacas e o cesto cos ranchos. Ou fun eu que xa non sentín ren. Recolleunos en Cervantes o home aquel, a min e a unha presada máis, e recolleu os cartos. Nunha rubia fomos baixando ate o apeadeiro do tren"

"Solamente recuerdo que usted dijo que cuando yo saliese de casa usted, abuela, dejaba de enviar. Que por su garganta no pasaría otro cacho de pan, fueron recuerdos nada más, ni siquiera las luzadas con las que la tormenta señalaba aquella marcha, era como si en mi cabeza sólo quedara la luz blanca y 
su voz, abuela. Mi cuello aguantó la maleta todo el rato sin a penas notar molestias en la espalda como notaba con las sacas y el cesto de los cerdos. O fui yo que no sentí nada. Nos recogió en Cervantes aquel hombre, a mi y a algunas más, y recogió el dinero. En una furgoneta bajamos hasta el apeadero del tren".

Se trata de un monólogo interior en el que Merce, el personaje central, evoca a su abuela, como hará en otros dos momentos del filme. En apariencia la suya es una historia ordinaria de alguien que sale de la aldea, que se pone a trabajar como mucama en una casa de clase media porteña de la época (con cocinera italiana además de sirvienta) y que un día es puesta en la calle sin lugar a donde ir, ni a quien acudir.

Merce pasa tres días y tres noches encrequenada en la Estación Constitución, lugar de pasaje de emigrantes, donde el azar hará que una chica que viajara con ella en el barco reclamada por unos tíos sin hijos, la reconozca y consiga que Merce reaccione a través de Etelvina, una costurera, y de Villar, otra emigrada de antes de la guerra. Junto a ellas la vida de Merce, al entrar a trabajar en una fábrica de cremalleras, da un giro imprevisto. En esta fase dorada Merce se va abriendo hacia el exterior, intenta comportarse como las demás, casa con el gallego Severino, propietario de una fábrica de calzado, y asiste a clases de contabilidad en alguna de las Sociedades Galegas.

Una fuerte transformación emocional, al pre-sentir la posibilidade de un idilio amoroso del que también el azar ala separará, se transforma en abatimiento y en un desinterés profundo por el tipo de vida que lleva con su esposo, quien la hará dejar la fábrica de cremalleras para trabajar a su servicio.

Merce retorna hacia si misma a través de un proceso traumático en el que pierde el sentido de la vista. Pero la cicatriz branca que asoma en sus ojos es, al mismo tiempo, el comienzo de una Merce que labra su disolución en un lugar que le permita el recordo y la recuperación de la palabra. 
"Recordo un paseo a pé do río, avoa. É o que agora recordo de todos os meus anos acó. Recórdoo como se fose o río de nós, avoa, ao mellor porque as augas son todas iguais. Ou porque eu querería que fosen as augas do Navia. Porque as augas acó están quedas e negras. Pero eu recordo, na mesma, ese paseo. E para poder recordalo aínda máis decidín ficar por acó, avoa”.

"Recuerdo un paseo al lado del río, abuela, Es lo que recuerdo ahora de todos mis años aquí. Lo recuerdo como si fuese nuestro río, abuela, a lo mejor porque las aguas son todas iguales. O porque quisiera que fuesen las aguas del Mavia. Porque aquí las aguas son estancas y negras. Pero, a pesar de todo, recuerdo ese paseo. Y para poder recordarlo todavía más, decidí, abuel, quedarme aquí”.

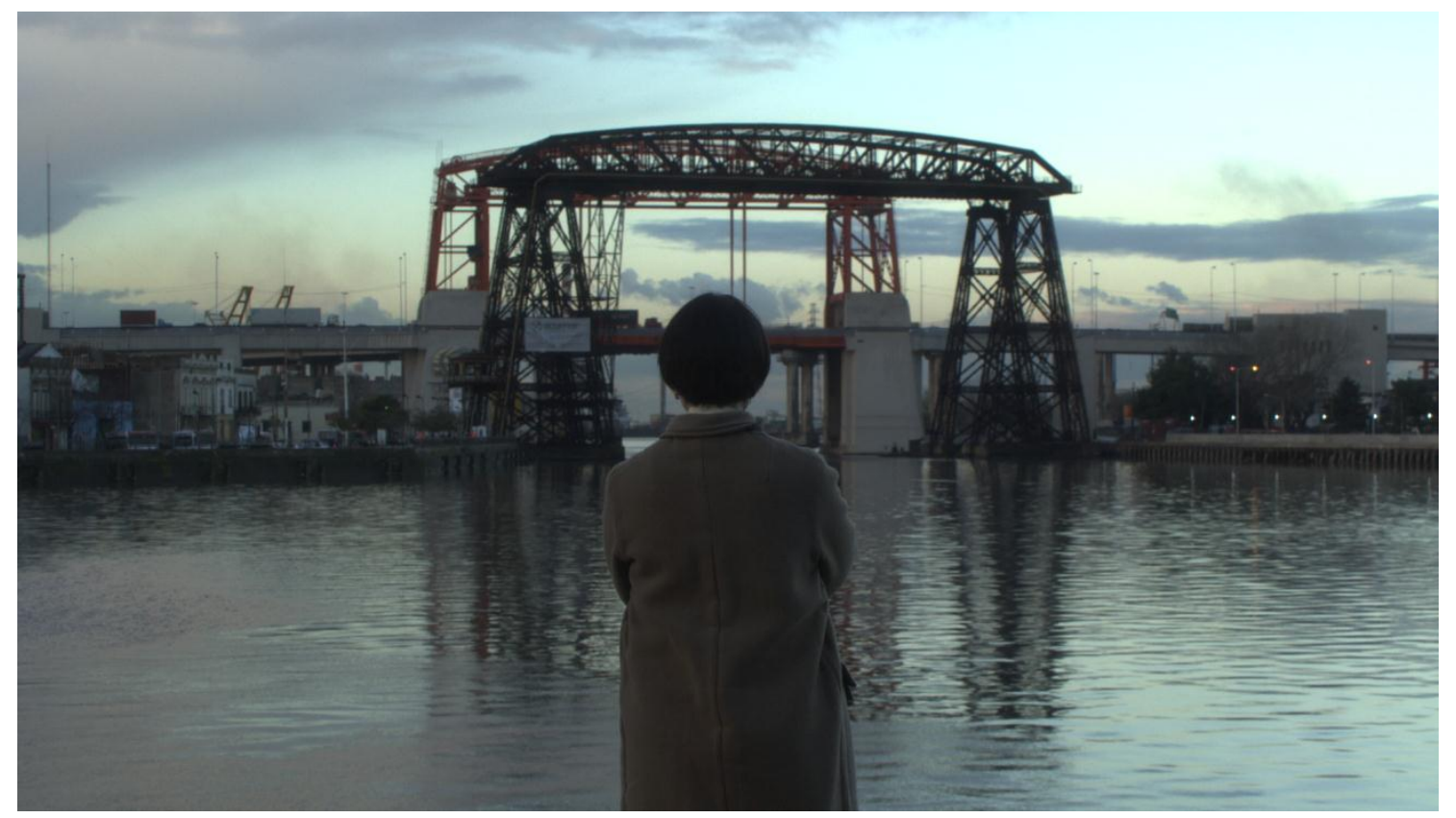

Filme-documento en su trama interna, además de buena parte de los materiales más singulares, Mercedes Méndez Fouz, la chica de la que parte el personaje de Merce, llegó a Buenos Aires en tercera clase, por debajo del auga, en el "Sierra Morena", con destino al servicio doméstico. Al poco tiempo la echaron a la calle porque, le dicen, no sabe limpiar. Y Mercedes Méndez Fouz, sin saber a donde ir, pasa tres días y tres noches en la Plaza Constitución, un lugar rodeado de 
prostíbulos, por donde deambulan los y las “sin papeles" de todas las épocas.

Este es el punto cero de la historia, de un filme de mujeres, de mujeres que sirven, de mujeres aisladas en sus miedos, en sus querencias, en su imposibilidad de deseo por y para ser buenas criadas. Mujeres sin cuerpo, más allá de aisladas, también de si mismas, que al dar comienzo a un viaje incierto hacia su propio cuerpo lo hacen, como primer indicio, con la recuperación del habla.

Filme de pasajes, con momentos de muerte y momentos de renacimiento, $A$ cicatriz branca es una película de silencios, de heridas invisibles que en determinados momentos se expresan en la duración de un plano, en su tempus interno, en un gesto mínimo, en romper la lógica de un comportamiento hasta y para hacernos resentir la historia del siglo.

En algún momento anoté una frase de la que no recuerdo la autoría: nos sentíamos libres porque nos faltaba la lengua con la que poder expresar que no teníamos libertad. Y esta frase, que no está en la película, es el cuerpo de Merce.

\section{Arte utilitario no reconciliado}

Entramos así en una suerte de paradoja, entre la carencia de un autoretrato comunal y carnal, del cuerpo con el que transitamos territorios opacos, y la sospecha de que somos seres con posibilidad de mirar y de construir modos de pensarnos a nosotros mismas como material capaz de desprender una inscripción luminosa, transitiva y querida que se prende a las tecnologías que la imitan y la materializan, adjetivadas como technologies of truth y por prácticas que nos conducen a canonizar lo observacional, el reciclaje de los objetos de andar por casa, la exploración constante de los vocabularios más sedimentados, el deseo, lo que te afecta/los afectos que están en esa consigna que resume los feminismos del siglo y que marca nuestra escritura elemental, "lo personal es político", con una particular apuesta: lo subjetivo como parte de lo objetivo, el modo de pensamiento como fenomenológico, la memoria como asunción de la experiencia y, una 
vez más, un material tan a mano como el cuerpo. De Nan Goldin a Anne Sophie Calle.

En una obra recién y también comunal, coordinada por Fran Zurian, Imagen, cuerpo y sexualidad, escribo sobre el trabajo del director artístico de mis filmes :

"Al declarar la elección de la fotografía como acercamiento al cuerpo, Bernardo Tejeda se sitúa de manera consciente en una de las prácticas creativas del feminismo, en el uso de las technologies of truth, que enlazaron la autoreferencia, la reproducción del "yo", con la fascinación por la semejanza,(...) Lo documental en sentido laso pasa, así, a ser esa experiencia que se constituye al recodificar fotos personales, diarios, cartas, imágenes anónimas, discursos oficiales para generar justo lo contrario, ensayos de autobiographical fiction, el tacón de aguja amenazando el engranaje tan rodado de todo el sistema"

Según todas las pistas, las prácticas artísticas de lo femenino pasan por la autoreferencia y por la reproducción del self, por la modalidad documental. O así se desprende de la afirmación de Vivian Sobchack a propósito del cine de no ficción hecho por mujeres: "Documentary is less a thing than an experience" (el documental no es tanto una obra como una experiencia) y no debe resultar casual la existencia de tratados seminales sobre la auto-conciencia, por ejemplo la propuesta de Julia Lesage en "Women's Fragmented Conciousness in Feminist Experimental Art biographical Video", donde se nos entrega un repertorio de figuras de estilo que siempre invito a localizar. Figuras que nos re-envían a esta conclusión de la Lesage:

"For these videomakers, to show and edit an autobiographical work entails their conceptually reformulating realtions between women's mind, body, emotions, and history -especially family history (...) They porsue an epistemological investigation of what kinds of relations might constitute the self, using as a laboratory their own consciousness" 
Figuras que ahora resumo en aquellas que pasan por la confrontación de la voz con el documento: la ironía y la retranca en relación con fotos, diarios, cartas, metraje encontrado, imágenes publicadas, archivos, relatos oficiales y desde una actitud de exploración de lo cotidiano, de la vida de a diario en lo que se etiquetó como "homevideomaking" para ir hacia la fabulación como modo de generar formas de pensamiento: "autobiographical fiction" y los llamados "conceptual films". Hasta tocar con los dedos el universo digital.

Os invito, ahora, a consultar la web del ESCAC y a recuperar "Feminismos en el escenario electrónico", en el décimo aniversario de su anticipación en la Primera Internacional Cyberfeminista (Documenta de Kassel, 1997) organizada por OBN (Old Boys Network). Por allí andaban Donna Haraway -que lanzó la frase "Todas somos Cyborg"-, Sadie Plant, las indecentes VNS Matriz y que nos resultan de gran utilidad a la hora de plantearnos una generalogía de los lenguajes que la tecnología trajo para el arte de género y poder constatar que éste sigue marcado por el cuerpo como gran contenedor de la opción sexual, de la étnia, la edad, la clase social, la cultura. el artificio expresivo y comunicativo, el habla.

Diez años más tarde de esta singular y contemporánea Internacional, en 2007, Ana Martínez Collado, Rosa Martínez, Virginia Vilaplana... nos hablaron del arte como territorio expandido y nos hicieron entender este adxectivo como el deber de intervención y de inclusión, de dar entrada no sólo a nuevas fórmulas, a otros materiales y propuestas, sino a un segmento extrañado, marginalizado de la creación, el arte como acto solidario, colaborativo y compartido más una palabra que retorna a todos los ambientes, la utopía: utopía como actitud, como asociación, interacción, investigación, como diversidad, como comunicación transversal desde esta misma diversidad: un vocabulario nuevo que podemos extrapolar a nuestro contexto y que nos sitúa, de nuevo, en lo uno y lo múltiple como solución, lo subjetivo en lo objetivo, la tecnología como herramienta identitaria e intercultural. 
Y a día de hoy volvemos hacia los ejemplos que rozan con sus dedos el documental, hacia la voz autoral que, sobre una imagen de mares en movimiento, se dirige a nosotras y nos da noticia de alguien que no es, de ese personaje común que se mueve en los bordes y que jurídicamente no existe. El plano no es mostrativo, no es un plano indicial, es un plano poseedor de un "realismo ontológico" que lo hace verdadero: estamos en presencia del lugar -material y simbólicodonde las migraciones del nuevo siglo se debaten. La cineasta, escritora e investigadora Ursula Biemann desenvolvió varios proyectos de frontera y de trata, que suele definir como un discurso en torno al trabajo migrante: entre España y Marrocos; entre México y USA, del Este hacia el Oeste... Movilidad, tecnología y género son sus marcas, no solamente por el dispositivo digital que le permite la máxima performatividad sino por la consciencia de la conexión.

La fuerza (militarización del espacio/patriarcado), la vigilancia y la fragmentación del cuerpo como archivo, como pieza a controlar; la pobreza, la crueldad de la tierra, el abandono, la sexualización y el desplazamiento de mujeres. La trata entre froteras - de Ciudad Juárez a Melilla- y la posición de una autora que no asume el feminismo con categorías universales sino locales, que analiza el movimiento global y transnacional de masas humanas y de las mujeres siguiendo la ruta de otras merancías.

Todo comienza en Performing de Border, 1999, en Ciudad Juárez, con la maquiladora; todo pasa en torno a un enclave donde las mujeres son ensambladoras y en una zona de desapariciones, de feminicidio en la que, como en otras zonas, esos cuerpos son un número, un catálogo sin datos. Y esa frase de una participante en el trabajo de Ursula: vendes tu vida, vendes tu tiempo... que me devolvió la otra cara de aquella situación efímera en el XIX que Rancière nos entrega en la noche del proletariado y que son, también, todas las emigrantas.

Somos, al mismo tiempo que ellas, esa perdida total de la querencia. De la belleza. De la disponibilidad amatoria. Mujeres que sobreviven en la representación de esa otra que ni son, ni tuvieron posibilidad alguna de ser. Deuda, ésta, más allá de la historia; herida difícil, muy difícil de zurcir. 
Esta sutura fue el móbil no confeso de $A$ cicatriz branca. Lo no representable. La parálisis: en la garganta, en el habla, en el cuerpo, en el pensamiento. $\mathrm{Y}$ el cuerpo encrequenado en una plaza, en un camión, en tierra de nadie, en las redes poderosas de las mafias.

Hasta que ellas van y son quien de decirlo. Y de actuar.

\section{Referencias bibliográficas}

Baumann, Ursula, "A World of Matter and Mobility" en www.geobodies.org

Ettinger, Bracha, Regards et espace-de-boprd matrixiels, 1999, La lettre volée, Bruxelles

Ledo Andión, Margarita/ Turbau, Anna (fotografías), Linguas Mortas. Serial Radiofónico, 1989, Sotelo Blanco, Santiago de Compostela

Mondzain, Marie-Jose, "Pour l'image, présomption d'innocence" en Images documentaires, 35/36, 1999

Rancière, Jacques, La nuit des prolétaires-Archives du rêve ouvrier, 2005, Fayard, Paris

VV.AA: A voz e a palabra. Coloquio sobre a batalla dos xéneros, 2005, CGACXunta de Galicia, Santiago de Compostela.

www.acicatriz branca.com

Zurian, Francisco A.(Ed.) Imagen, cuerpo y sexualidad. Representaciones del cuerpo en la cultura audiovisual contemporánea, 2014, Ocho y Medio, Madrid 


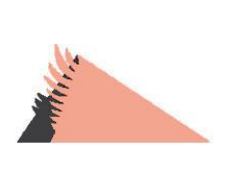

\section{Autores}

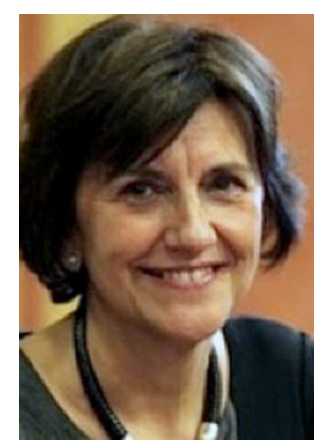

Emelina Fernández Soriano. Licenciada en Derecho, Doctora en Ciencias de la Comunicación y profesora titular de la Facultad de Ciencias de la Comunicación de la Universidad de Málaga. Perteneció al Consejo de Administración de la RTVA durante siete años desde su creación. Ha sido miembro de la Delegación Española del Consejo de Europa, Comisión de Comunicación y Cultura, y de la UEO. También perteneció a la Comisión Constitucional, ha sido vice portavoz de la Comisión mixta Congreso-Senado de control de RTVE y portavoz en el Senado de todos los temas relacionados con la Comunicación. Ha sido ponente en el Senado de la Ley de Creación de la nueva Corporación de RTVE, de la Ley de la Publicidad Institucional, de la Ley de Financiación de la TV pública y de la Ley General de Comunicación Audiovisual. Senadora por la provincia de Málaga desde 2004. Miembro del primer Consejo de Administración de la RTVA, desde 1987 hasta 1994, siendo su portavoz durante esos siete años. Es autora de publicaciones sobre las industrias culturales, comunicación y género, historia de la RTVA, numerosos artículos sobre los Consejos Audiovisuales de España, entre otros. 


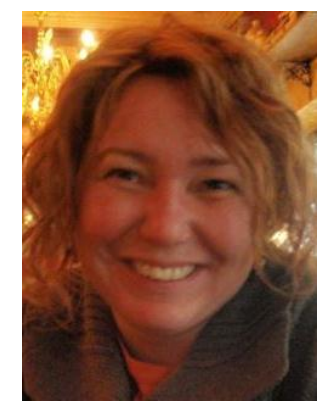

Inmaculada Postigo Gómez. Doctora en comunicación y master en Nuevas Tecnologías de la Información y la Comunicación. Profesora del Dpto. de Comunicación Audiovisual y Publicidad de la Universidad de Málaga. Ha sido coordinadora desde 2004 del programa de doctorado interuniversitario "Nuevas Tecnologías en Comunicación" e imparte docencia en el master oficial en Igualdad y Género en la Universidad de Málaga.

Sus líneas de investigación contemplan el análisis de las producciones discursivas desde una perspectiva crítica.

Ha realizado estancias pre y postdoctorales en Universidad del Valle de Atemajac (México), Universidad Mayor y Universidad de Viña del Mar (Chile), Universidad Nacional del Centro de la Provincia de Buenos Aires (Argentina), Universidad de Salzburgo (Austria), Università di Lingue e Comunicazione Milano (Italia), The Hague University (Holanda), Centro Internacional de Estudios Superiores para América Latina-CIESPAL- (Ecuador).

Ha dirigido el Observatorio del tratamiento informativo de la violencia de género con especial atención a la identidad étnica/cultural, proyecto de investigación de excelencia de la Junta de Andalucía. También ha participado como investigadora en diversos proyectos de investigación y cooperación, tales como Las nuevas Tecnologías de la información y la comunicación como facilitadoras del desarrollo educativo rural: análisis y evaluación de su eficacia en Ecuador; La calidad en los sistemas de educación superior de España y Costa Rica: comparación y mejora en Costa Rica; Participación y desarrollo de comunidades a través del cooperativismo agrario. Evaluación de proyectos basados en organizaciones populares", en Bolivia; Violencia de género: Estrategias y prácticas comunicativas para el empoderamiento de la mujer, en Guatemala.

Desde 2009 ejecuta proyectos de cooperación en Bolivia, junto con el CIDES de la Universidad Mayor de San Andrés, centrados en el uso de la comunicación para prevenir y erradicar la violencia de género. 


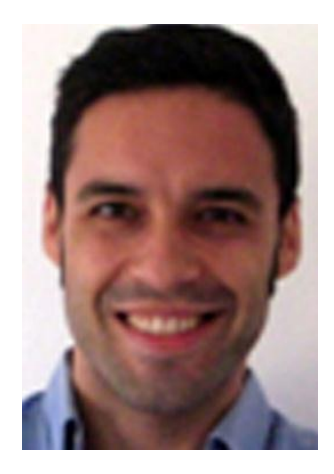

Antonio A. Caballero Gálvez. Doctor en Comunicación Audiovisual y Publicidad por la Universidad Complutense de Madrid. Sus líneas de trabajo se centran en el estudio de la representación de las identidades de género en la cultura audiovisual contemporánea; (nuevas) masculinidades y estética del videoarte. Es coordinador del Seminario Permanente de Investigación Interdisciplinar Género, Estética y Cultura Audiovisual (GECA) de la Universidad Complutense de Madrid.

Ha trabajado como investigador del Observatorio andaluz de violencia machista en los medios audiovisuales y ha realizado diversas estancias de investigación predoctoral (Universitat Rovira i Virgili y Humboldt Universitat zu Berlin) y postdoctoral (Universidad Mayor de San Andrés, La Paz). Ha sido profesor invitado de la asignatura Contemporary Masculinities en Stony Brook State University of New York. Algunas de sus últimas publicaciones son "Redefiniendo el videoarte: orígenes, límites y trayectorias de una hibridación en el panorama de la creación audiovisual contemporánea" (Revista ICONO14, 2014) y "Comunicación y subversión: estudios de género desde la cultura visual" (Journal de Comunicación Social-Universidad Católica Boliviana San Pablo, 2015).

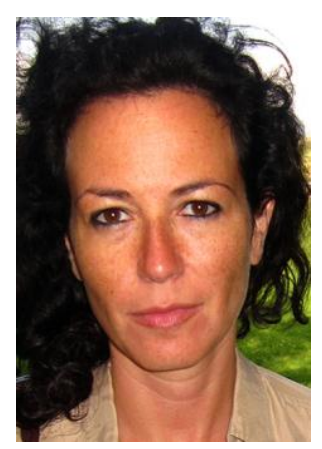

Concha Barquero Artés. Licenciada en Comunicación Audiovisual por la Universidad de Málaga (1999) y Máster en escritura para cine y televisión por la Universidad Autónoma de Barcelona (2000), cuenta con una amplia trayectoria profesional en la televisión divulgativa y el documental. Durante una década fue redactora y guionista del programa Tesis (2001-2011), de Canal Sur 2 
Andalucía, un espacio televisivo de referencia avalado, entre otros, con el Primer Premio de Televisión del Consejo Asesor de RTVE de Andalucía.

Entre sus trabajos como realizadora destaca el largometraje documental Pepe el andaluz. (2012), presente en más de 20 festivales internacionales y que ha obtenido numerosos reconocimientos como el Premio Canal Plus al Mejor Documental Español en Documenta Madrid (2013). Además, ha co-dirigido otros proyectos con clara vocación social, como los documentales El reverso de la realidad (2007) y Warmi. Algunos apuntes sobre La Pazy sus mujeres (2014).

En el ámbito académico ha llevado a cabo estudios relacionados con el cine documental y el tratamiento informativo de la violencia de género. Entre sus publicaciones se cuentan "Experimentación y documental: aproximación al panorama actual de la no ficción en España", en el libro Historia y estética del videoarte en España (2011) o "Un despertar revulsivo: prácticas colaborativas en el documental sobre el 15-M", en Fonseca Journal of Communication (2013). Es miembro del equipo investigador de Observatorio andaluz de la violencia machista en los medios audiovisuales de la Universidad de Málaga desde octubre de 2013.

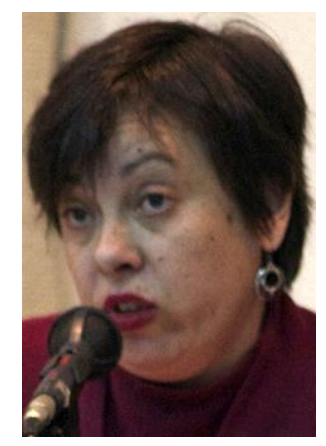

Ana Jorge Alonso. Doctora en Comunicación. Profesora del Departamento de Comunicación Audiovisual de la Universidad de Málaga. Desde su entrada en la Universidad se adentra en una línea general de investigación que aborda desde una perspectiva crítica las relaciones entre el poder y la comunicación, y que ahonda al mismo tiempo en la línea de Estudios de Mujeres. La publicación en 2004 de Mujeres en los medios, mujeres de los medios. Imagen y presencia femenina en las televisiones públicas: Canal Sur TV en la editorial Icaria, de gran tradición en el ámbito de las cuestiones de género, ha sido incluida como obra de referencia en 
los Estudios de Género, en varios repositorios universitarios e institucionales españoles y extranjeros. Entre 2003 y 2009 coordina el Programa de Doctorado en Comunicación y Poder de la Universidad de Málaga, en el que se encarga de una línea de docencia e investigación en «Estudios de Mujeres en Comunicación».

La preocupación por el conocimiento de aspectos que limitan las condiciones materiales para el ejercicio del derecho a la igualdad en los procesos comunicativos ha ampliado su interés investigador hacia las migraciones y la cooperación. Trabaja en diversos proyectos de cooperación, tanto en formación como en investigación, en varios países de América Latina. La conjugación de la comunicación para el desarrollo con la perspectiva de género fue el marco de la primera estancia (2006) en La Paz (Bolivia) en la Universidad Andina Simón Bolívar y en la Universidad Mayor de San Andrés; institución con la que sigue colaborando a través de su Centro de Investigación y Estudios de posgrado en Ciencias del Desarrollo (CIDES).

Actualmente, participa en el proyecto de investigación del Plan Nacional I+D+i "El sistema de investigación en España sobre prácticas sociales de Comunicación. Mapa de Proyectos, Grupos, Líneas, Objetos de estudio y Métodos" (MapCom)"

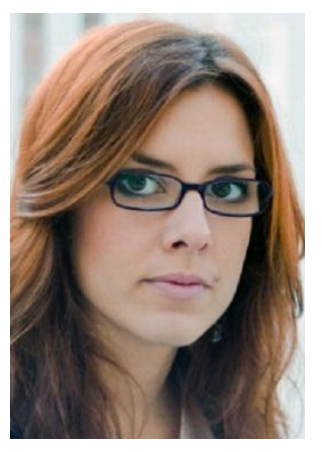

Ruth Ainhoa de Frutos García. Doctora en Periodismo con mención internacional por la Universidad de Málaga y miembro del proyecto del Plan Nacional I+D $+\mathrm{i}$ "El sistema de investigación en España sobre prácticas sociales de Comunicación. Mapa de Proyectos, Grupos, Líneas, Objetos de estudio y Métodos" (MapCom)" (2013-47933-C4-3-P).

Durante estos años, ha participado en congresos exponiendo sus aportaciones en la investigación de los indicadores mediáticos en general y de género para medios de comunicación, alfabetización 
mediática, libertad de expresión, observatorios de comunicación en América Latina e índices de transparencia, en particular.

Ha realizado estancias de investigación en la Università degli Studi di Torino (Italia), la Universidade Estadual de São Paulo Júlio de Mesquita Filho (Brasil), el Media Industry Research Institute de la Universidad de Shangái (China) y la Universidad de la República (Uruguay).

Licenciada en Periodismo por la Universidad de Valladolid, donde simultaneó dichos estudios con los de Derecho, ha trabajado en la Cátedra UNESCO de Comunicación de la Universidad de Málaga (2009-2010) y en el Centro UNESCO de Turín (2010-2011). Anteriormente había colaborado a través de contratos y becas con diversas empresas de comunicación o medios, como El Norte de Castilla, Nuevo Cuño o la Agencia Efe.

Su interés por los derechos humanos la llevaron a colaborar en la Asamblea Permanente por los Derechos Humanos en Buenos Aires (Argentina) dentro del programa Prácticas Académicas en Proyectos de Cooperación, de la Universidad de Valladolid (PACID) y a desempeñar distintos cargos como activista de Amnistía Internacional en Valladolid, Granada y Málaga.

Actualmente compagina sus funciones como investigadora en la Universidad de Málaga con las de miembro del Observatorio de Cooperación Internacional para el Desarrollo de la Universidad de Valladolid y las de responsable del grupo de Comunicación, redes sociales y libertad de expresión de Amnistía Internacional en Málaga.

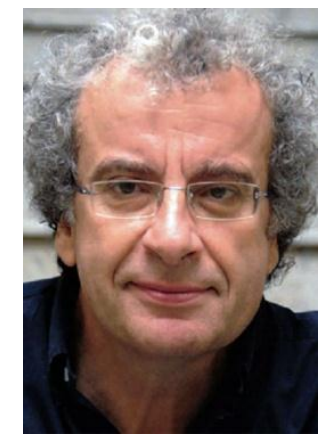

José María Calleja. Doctor en Ciencias de la Información por la Universidad Complutense, profesor de periodismo en la Universidad Carlos III, licenciado en Historia y periodista. Profesor en el Master de Relaciones Internacionales de la Universidad San Pablo-CEU, profesor invitado en el Master de Relaciones de Género de la Universidad de Zaragoza, es miembro del Instituto de Estudios de Género de la Universidad 
Carlos III. Premio Espasa de Ensayo (2001) ha publicado trece libros, los dos últimos "La Violencia como noticia" (2013), "Informar sobre la violencia contra las mujeres. Guía de buenas prácticas para los medios de comunicación" (2014). Ha sido redactor jefe del canal de noticias $\mathrm{CNN}+$, donde dirigió el programa "A debate". Colabora en El País, Eldiario.es y en los periódicos del grupo Vocento. Participa en diversos programas de Televisión y Radio.

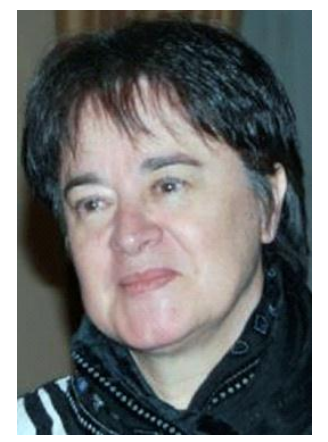

Trinidad Núñez Domínguez. Doctora en Psicología, profesora Titular de Universidad adscrita al Área de Psicología Social de la Universidad de Sevilla. Cuenta con treinta años de experiencia docente. Ha participado en casi una decena de proyectos de investigación competitivos, tanto nacionales como europeos, manteniendo como áreas de interés el estudio sobre los medios de comunicación, la socialización, los prejuicios y el género.

En el año 2013 obtiene dos premios significativos: El Premio Meridiana a las iniciativas que promueven el valor de la igualdad en jóvenes, que concede la Junta de Andalucía y el XX Premio Carmen de Burgos a la divulgación feminista, que concede la Universidad de Málaga (Andalucía-España) por sus artículos de opinión en la prensa. Alguno de sus últimas publicaciones son: "La violencia machista en el cine. Materiales para una intervención psicosocial", "Directoras de cine español. Ayer, hoy y mañana mostrando talentos" y "Competencias psicosociales para profesionales de los medios". 


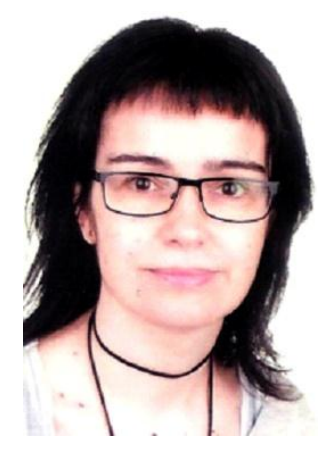

María José Gámez Fuentes. Profesora titular del Departamento de Ciencias de la Comunicación de la Universitat Jaume I. Canaliza su investigación a través del Instituto de Desarrollo Social y Paz (del que es secretaria) y del Instituto de Investigaciones Feministas de dicha universidad. Sus trabajos abordan la comunicación para el cambio social desde una perspectiva feminista y de género, con especial interés en la violencia representacional.

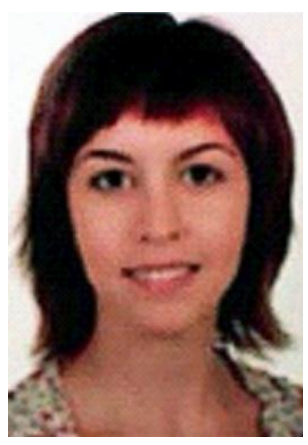

Laura Castillo Mateu. Es becaria FPU adscrita al Departamento de Ciencias de la Comunicación de la Universitat Jaume I e investigadora del Instituto de Desarrollo Social y Paz de dicha universidad. Centra su interés en cuestiones de género, feminismos y representación mediática.

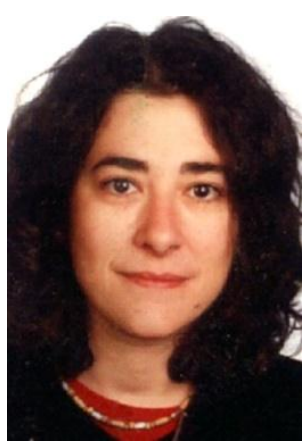

Rocío de la Maya Retamar. Doctora en Comunicación por la Universidad de Málaga y Licenciada en Ciencias de la Imagen por la Universidad Complutense de Madrid. Desde 1994 es profesora del Departamento de Comunicación Audiovisual y Publicidad de la Facultad de Ciencias de la Comunicación de la Universidad de Málaga, desarrollando su labor investigadora en el ámbito de la industria audiovisual, desde la producción de contenidos hasta las nuevas formas de distribución y exhibición digital. Otras áreas de interés son los videojuegos, el cómic y los estudios de género. 


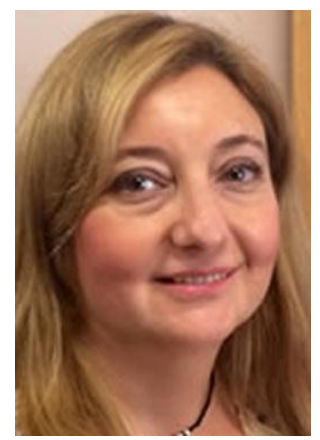

Teresa Vera Balanza. Doctora en Historia Contemporánea (Universidad de Málaga, 1999). Integrante del Seminario de Estudios Interdisciplinarios de la Mujer de la Universidad de Málaga (SEIM-UMA). Coordinadora del Máster Oficial en Igualdad y Género de la UMA (2010-2015) y Vicedecana de Investigación e Innovación de la Facultad de Ciencias de la Comunicación desde 2007. Imparte docencia en Teorías de la Comunicación para el Grado de Periodismo; Feminismo e Información: comunicación y participación, en el Máster en Investigación en Comunicación Periodística; La Sociedad de la Comunicación desde una perspectiva de género, en el Máster Oficial en Igualdad y Género

Participa actualmente en los proyectos Las audiencias lejanas. Memoria televisiva y hábitos de recepción comparados de emigrantes españoles y residentes extranjeros europeos, del Ministerio de Industria, Ciencia e Innovación CSO2012-31261, dirigido por el Dr. Juan Francisco Gutiérrez Lozano (UMA); Comunicación y Periodismo para la participación ciudadana en el seguimiento y evaluación de la gestión de los gobiernos locales del Ministerio de Industria, Ciencia e Innovación CSO2012-34687, dirigido por la Dra. Amparo Moreno Sardà (UAB); y en el Observatorio del tratamiento informativo de la violencia de género con especial atención a la identidad étnica/cultural P11-TIC-7999, Proyecto de Excelencia de la Junta de Andalucía dirigido. por la Dra. Inmaculada Postigo Gómez (UMA). www.obvio.uma.es 


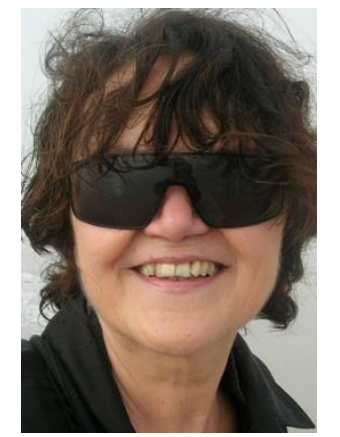

Margarita Ledo Andión. Catedrática de Comunicación Audiovisual de la Universidad de Santiago de Compostela. Cineasta y escritora, es vicepresidenta primera de la AE-IC y directora del Grupo de Estudos Audiovisuais de la USC.

En la actualidad es investigadora principal del proyecto de $\mathrm{I}+\mathrm{D}+\mathrm{i}$ Hacia el espacio digital europeo: el papel de las pequeñas cinematografías en V.O.

Es autora del capítulo "Vestigio y extrañeza: sobre la obra de Bernardo Tejeda" en Imagen, cuerpo y sexualidad, 2014, Francisco Zurian (ed.), Madrid, Ocho y Medio. Su libro Cine de fotógrafos, Gustavo Gili, Barcelona, 2005, fue Premio Fundació Espais d'Art Comtemporani.

En 2013 estrenó su primera ficción A cicatriz branca que con sus largometrajes documentales Santa Liberdade (2004) y Liste, pronunciado Lister (2007) completan su trilogía sobre el siglo XX.

Se declara feminista y agitadora cultural. 